\title{
Metoda konačno-diskretnih elemenata za statičku i dinamičku analizu tankih lukova i ljusaka
}

Uzelac, Ivana

Doctoral thesis / Disertacija

2015

Degree Grantor / Ustanova koja je dodijelila akademski / stručni stupanj:

University of Split, Faculty of Civil Engineering, Architecture and Geodesy / Sveučilište u Splitu, Fakultet građevinarstva, arhitekture i geodezije

https://doi.org/10.31534/DocT.040.Uzel

Permanent link / Trajna poveznica: https://urn.nsk.hr/urn:nbn:hr:123:441266

Rights / Prava: In copyright/Zaštićeno autorskim pravom.

Download date / Datum preuzimanja: 2023-04-26

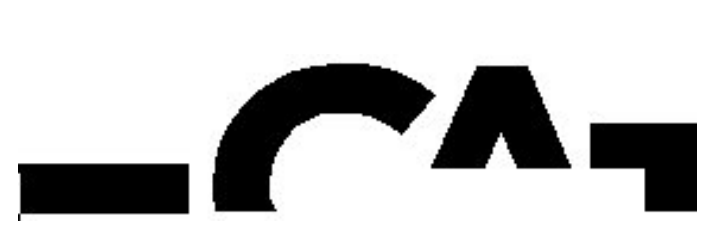

Repository / Repozitorij:

FCEAG Repository - Repository of the Faculty of Civil Engineering, Architecture and Geodesy, University of Split

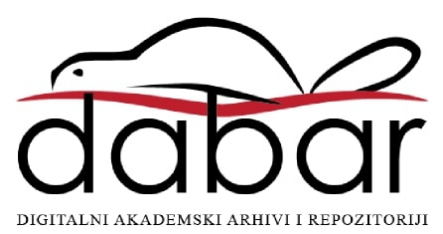




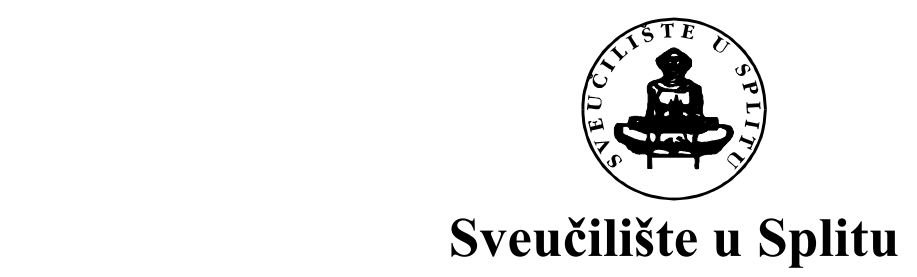

FAKULTET GRAĐEVINARSTVA, ARHITEKTURE I GEODEZIJE

Ivana Uzelac, dipl. ing. grad.

\section{METODA KONAČNO-DISKRETNIH ELEMENATA ZA STATIČKU I DINAMIČKU ANALIZU TANKIH LUKOVA I LJUSAKA}

Disertacija

Split, 2015. 
Ivana Uzelac, dipl. ing. građ.

Redni broj: 040

Ova disertacija predana je na ocjenu Fakultetu građevinarstva, arhitekture i geodezije Sveučilišta u Splitu u svrhu stjecanja akademskog stupnja doktora tehničkih znanosti u znanstvenom polju građevinarstvo.

Mentor:

Komentor:
Prof. dr. sc. Bernardin Peroš, dipl. ing. građ.

Prof. dr. sc. Ante Munjiza, dipl. ing. građ.

Povjerenstvo za ocjenu: Prof. dr. sc. Ante Mihanović, dipl. ing. građ. Prof. dr. sc. Bernardin Peroš, dipl. ing. građ. Prof. dr. sc. Darko Dujmović, dipl. ing. građ. 
Povjerenstvo za obranu:

Prof. dr. sc. Ante Mihanović, dipl. ing. građ.

Prof. dr. sc. Bernardin Peroš, dipl. ing. građ.

Prof. dr. sc. Darko Dujmović, dipl. ing. građ.

Rad je obranjen dana: 12. studenog, 2015.

Tajnica:

Saša Delić, dipl.iur. 
Rad sadrži:

132 stranice teksta

3 slike

106 crteža

18 tablica

225 citiranih referenci 
Ova disertacija ne bi bila napravljena bez pomoći kolega i prijatelja koji su bilo na direktan ili indirektan način pomagali u ovom radu. Posebnu zahvalnost dajem:

- mentoru prof. dr. sc. Bernardinu Perošu i komentoru prof. dr. sc Anti Munjizi za savjete $i$ vodstvo koje su mi pružili tijekom izrade ovog rada,

- članovima povjerenstva prof. dr. sc. Anti Mihanoviću i prof. dr. sc. Darku Dujmoviću za pregled rada i savjete,

- kolegi dr. Hrvoju Smoljanoviću za kontinuirani angažman i pomoć pri izradi numeričkih algoritama,

- ostalim kolegama sa Fakulteta gradevinarstva, arhitekture i geodezije na razumjevanju i podršci,

- te na kraju najveću i neizrecivu zahvalnost dajem Damiru i svojoj majci. 
Ivana Uzelac, dipl.ing.građ.

\section{METODA KONAČNO-DISKRETNIH ELEMENATA ZA STATIČKU I DINAMIČKU ANALIZU TANKIH LUKOVA I LJUSAKA}

\section{Sažetak}

U ovom radu su u okviru metode konačno-diskretnih elemenata razvijeni novi numerički modeli za simulaciju ponašanja tankih grednih i lučnih elemenata, te tankih konstrukcija ploča i ljusaka izloženih statičkom i dinamičkom opterećenju. Prikazane su do sada uvriježene metode proračuna predmetnih konstrukcija te njihove prednosti i nedostaci. Također, prikazane su osnove kombinirane metode konačno-diskretnih elemenata i razlozi njezinog odabira. Motivacija se nalazila na razvoju preciznih, robusnih i numerički povoljnih modela. Numerički model za analizu tankih grednih i lučnih konstrukcija koristi ravne dvočvorne elemente oslobođene rotacije, i u obzir uzima linearno elastično ponašanje materijala, konačne pomake, konačne rotacije i male deformacije. U radu su detaljno opisani mehanizmi prijenosa uzdužne i savojne krutosti kod grednih konačnih elemenata. Model je implementiran u postojeći open-source program Yfdem, temeljen na kombiniranoj metodi konačno-diskretnih elemenata. U sklopu rada provedena je verifikacija predloženog modela, te prikazana njegova primjena u seizmičkoj analizi lučnih konstrukcija.

Također, razvijen je novi numerički model za analizu tankih ploča i ljusaka. Model za ploče i ljuske koristi ravne tročvorne trokutaste elemente oslobođene rotacije i u obzir uzima linearno elastično ponašanje materijala, konačne pomake, konačne rotacije i male deformacije. U radu su detaljno opisani mehanizmi prijenosa membranske i savojne krutosti kod trokutastih konačnih elemenata. Model je implementiran u postojeći opensource program Yfdem. U sklopu rada provedena je verifikacija predloženog modela, te je prikazana njegova primjena na tipske problema stabilnosti ploča i ljusaka. Predložene su daljnje smjernice za nadogradnju razvijenog programa u smjeru interakcije i matelijarne nelinearnosti.

Ključne riječi: kombinirana metoda konačno-diskretnih elemenata, gredni element, luk, izvijanje, tročvorni trokutasti konačni element, tanke ploče, tanke ljuske, dinamička analiza, izbočavanje. 
Ivana Uzelac, dipl.ing.građ.

\section{FINITE-DISCRETE ELEMENT METHOD FOR STATIC AND DYNAMIC ANALYSIS OF THIN ARCH AND SHELL STRUCTURES}

\section{Summary}

This thesis presents new numerical models for analysis of thin beam and arch structures and thin plate and shell structures based on the combined finite-discrete element method (FDEM). The new models perform quasistatic and dynamic analysis. The thesis also presents an overview of the established numerical tools for the analysis of arch and shell structures, together with their strengths and disadvantages. The bases of the combined finite-element method and its strengths are also presented. The main motivation was the development of precise, robust and computationally efficient numerical models. The model for the analysis of thin beam and arch structures uses straight two-noded rotation free finite elements, and takes into account linear-elastic material behaviour, finite displacement, finite rotations and small strains. The thesis describes axial and bending carrying mechanisms of a beam finite element in detail. The presented model is implemented into the open source FDEM package 'Yfdem'. Performance of the new numerical model is demonstrated on simple benchmark tests by a comparison with known analytical and numerical results. Its application for the seismic analysis of arch structures is presented.

This thesis also presents a new numerical model for analysis of thin plate and shell structures. The model uses three-noded triangular finite elements, and takes into account linear-elastic material behaviour, finite rotations, finite displacements and small strains. The thesis describes membrane and bending carrying mechanisms for triangular finite element in detail. The model is implemented into the open source FDEM package 'Yfdem'. Performance of the new numerical model was demonstrated on simple benchmark tests by comparing it with the known analytical and numerical results. Its application in typical problems of stability of plate and shell structures is presented. Directions for further development and upgrade of the model in performing contact interaction and material nonlinearity are given.

Keywords: combined finite-discrete element method, beam element, curved structures, three-noded triangular finite element, thin plates, thin shells, dynamic analysis, buckling. 


\section{SADRŽAJ}

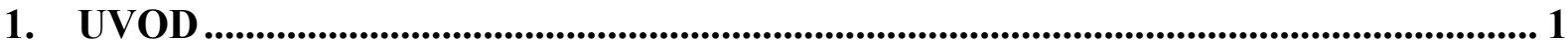

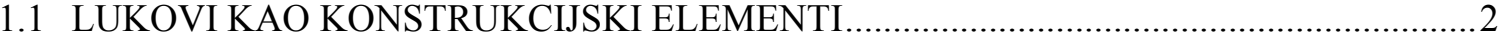

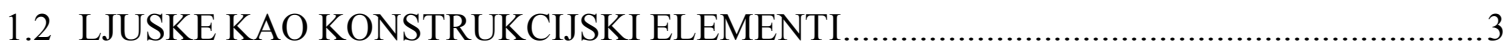

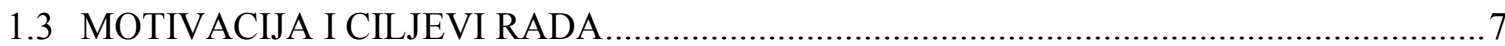

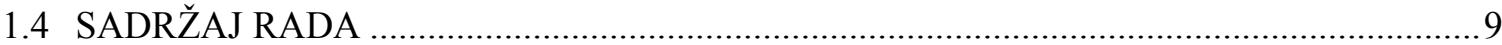

2. OSVRT NA MODELIRANJE KONSTRUKCIJA LUKOVA I LJUSAKA ............. 11

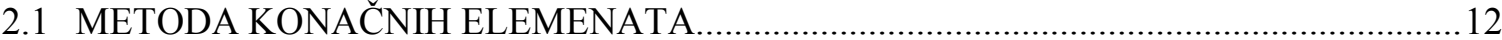

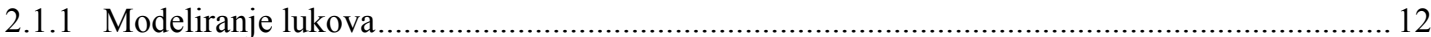

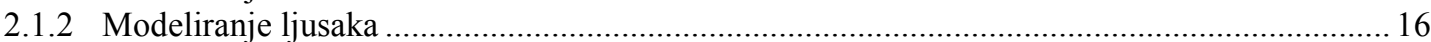

2.1.3 Trokutasti konačni elementi pri modeliranju ljusaka.............................................................. 18

2.1.4 Problematična ponašanja pri numeričkoj analizi lukova i ljusaka ................................................2 27

2.2 MODELIRANJE LUKOVA I LJUSAKA POMOĆU BEZMREŽNIH METODA I

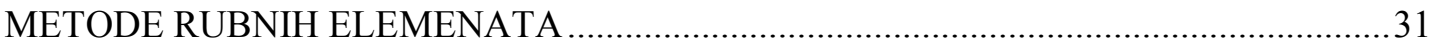

2.3 LUKOVI I LJUSKE U KOMBINIRANOJ METODI KONAČNO-DSIKRETNIH ELEMENATA

3. OSNOVE KOMBINIRANE METODE KONAČNO-DISKRETNIH ELEMENATA37

3.1 OBRADA 3D KONTAKTNE INTERAKCIJE U KOMBINIRANOJ METODI

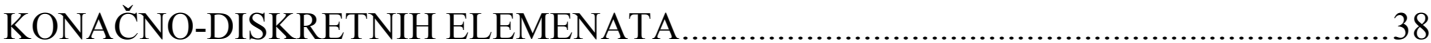

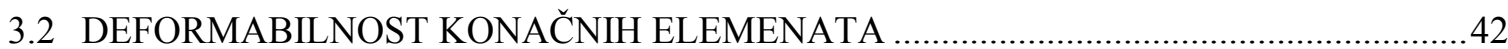

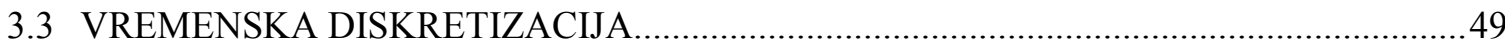

4. NUMERIČKI MODEL ZA ANALIZU KONSTRUKCIJA LUKOVA.................... 52 


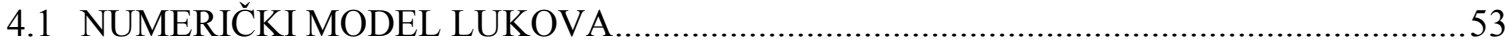

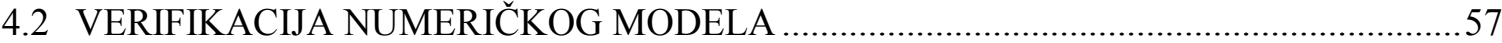

4.2.1 Prosta greda pod vlastitom težinom.................................................................................. 57

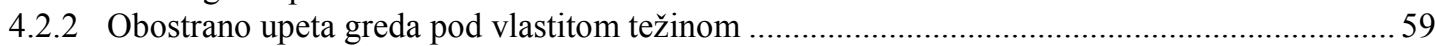

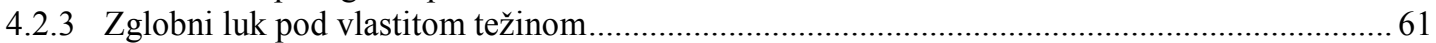

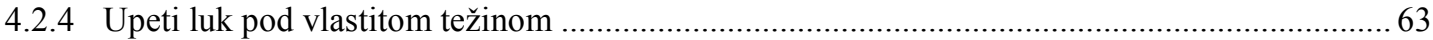

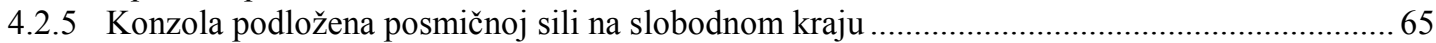

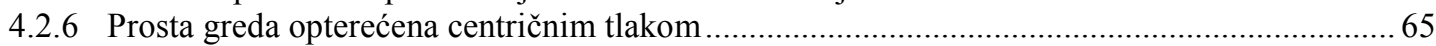

4.2.7 Luk podložen monotono rastućem koncentriranom opterećenju ................................................ 67

5. NUMERIČKI MODELI ZA ANALIZU KONSTRUKCIJA LJUSAKA .................. 69

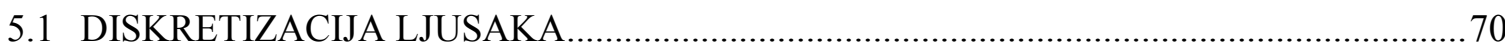

5.2 MODEL PRIJENOSA MEMBRANSKE KRUTOSTI KOD LJUSAKA ................................70

5.3 MODELI PRIJENOSA SAVOJNE KRUTOSTI KOD LJUSAKA …...................................72

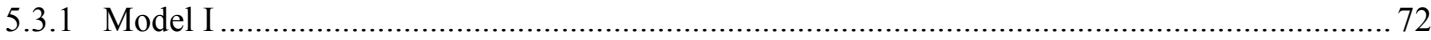

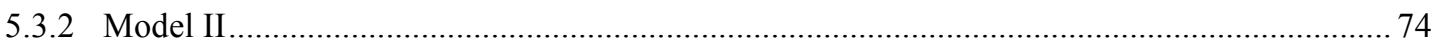

5.4 VERIFIKACIJA NUMERIČKOG MODELA - MODEL I .................................................79

5.4.1 Slobodno oslonjena kvadratna ploča pod jednoosnim savijanjem - model I ......................... 79

5.4.2 Slobodno oslonjenja kvadratna ploča pod dvoosnim savijanjem - model I ...........................8 80

5.4.3 Slobodno oslonjenja kružna ploča pod gravitacijskim opterećenjem - model I..................... 81

5.5 VERIFIKACIJA NUMERIČKOG MODELA - MODEL II ..........................................8. 83

5.5.1 Ploča pod vlačnim naprezanjem ............................................................................... 83

5.5.2 Slobodno oslonjena kvadratna ploča pod jednoosnim savijanjem....................................... 84

5.5.3 Slobodno oslonjenja kvadratna ploča pod dvoosnim savijanjem ...................................... 87

5.5.4 Slobodno oslonjena kružna ploča pod gravitacijskim opterećenjem ..................................... 89

5.5.5 Čelični luk pod gravitacijskim opterećenjem ............................................................... 92

5.5.6 Ljuska pod gravitacijskim opterećenjem ......................................................................... 94

5.5.7 Konzola podložena posmičnoj sili na slobodnom kraju ................................................... 97

6. PRIMJENA RAZVIJENOG MODELA U ANALIZI KONSTRUKCJA LUKOVA I

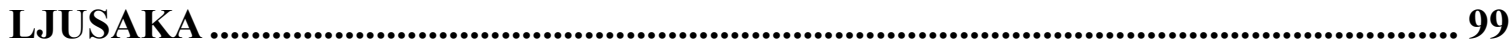

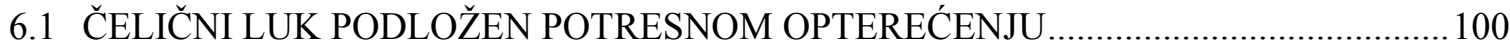

6.2 KVADRATNA PLOČA POD TLAČNIM OPTEREĆENJEM …….................................... 101

6.3 SLOBODNO OSLONJENA KVADRATNA PLOČA POD TLAČNIM

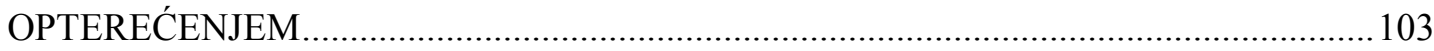

6.4 ČELIČNI CILINDAR POD TLAČNIM OPTEREĆENJEM .................................................. 105

7. ZAKLJUČCI I PRAVCI DALNJIH ISTRAŽIVANJA .......................................... 108

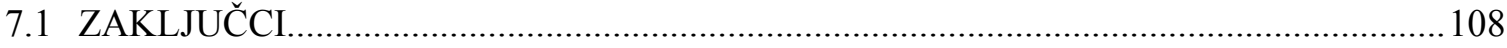

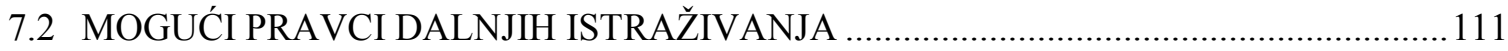

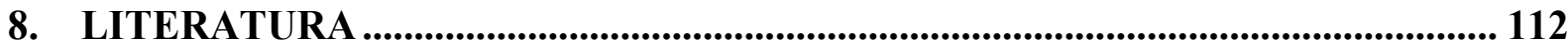




\section{UVOD}

Zakrivljene konstrukcije, klasificirane kao lukovi i ljuske, jedni su od najčešće korištenih struktura u prirodi i tehnologiji. Svoju široku primjenjuj ponajviše duguju sposobnosti premošćivanja "većih" raspona uz visok odnos čvrstoće i težine konstrukcije, te posjedovanje estetskih prednosti. Naime, gledano prema dimenzijama konstrukcije potrebnima za premošćenje određenog raspona, lukovi i ljuske posjeduju veću učinkovitost naspram drugih konstrukcijskih oblika. No međutim, određivanje optimalnog oblika takvih konstrukcija, dimenzioniranje, proračun stabilnosti i potrebnih karakteristika materijala može predstavljati jako zahtjevnu zadaću.

U ovom poglavlju približen je pojam luka i ljuske kao konstrukcijskog elementa, pojam tankih i debelih zakrivljenih konstrukcija, te njihova klasifikacija. Konstrukcije lukova razmatrane su ispred ljusaka iz razloga što lukovi u jednostavnijem kontekstu dijele sličnosti i obuhvaćaju probleme koji se susreću kod pri analizi ljusaka. To je također korisno pri razvoju numeričkih modela jer, ukoliko se određeni pristup pokaže zadovoljavajućim pri analizi konstrukcija lukova, isti može biti proširen na analiziranje konstrukcija ljusaka. Također, prezentirana je i motivacija iza izrade ovog rada, skupa sa novinama koje bi trebao donijeti. Na kraju je dat pregled svih poglavlja uključenih u ovu radnju. 


\subsection{LUKOVI KAO KONSTRUKCIJSKI ELEMENTI}

Za razliku od greda, lukovi poprečna opterećenja prenose kombiniranom akcijom savojne i aksijalne krutosti, što ih čini efektivnijima od ravnih konstrukcijskih elemenata. Povećanjem zakrivljenosti konstrukcijskog elementa dolazi do smanjenja momenta savijanja u konstrukciji, a uzdužna krutost postaje sve značajniji faktor pri prijenosu poprečnih opterećenja. Shodno tom principu, lukovi su još u rimsko doba omogućili izradu mostova, akvadukata te postojanje krovnih konstrukcija značajnijih dimenzija. Bez dostupnosti materijala koji može preuzeti vlačna naprezanja u prošlosti je bilo neizbježno konstrukcije oblikovati na način da se nalaze pod dominantno tlačnim stanjem naprezanja. To je uzrokovalo da danas pod pojmom "pravog luka" podrazumijevamo dominantnost tlačne sile u konstrukciji. Mehanički gledano, to je zapravo bio i konačan cilj kod konstrukcija lukova - smanjenje momenta savijanja uz prijenos opterećenja tlačnim potiscima prema osloncima lukova. Danas međutim, potpomognuto tehnološkim napretkom, omogućene su konstrukcije raznih omjera raspona i strelice luka (Slika 1.1).
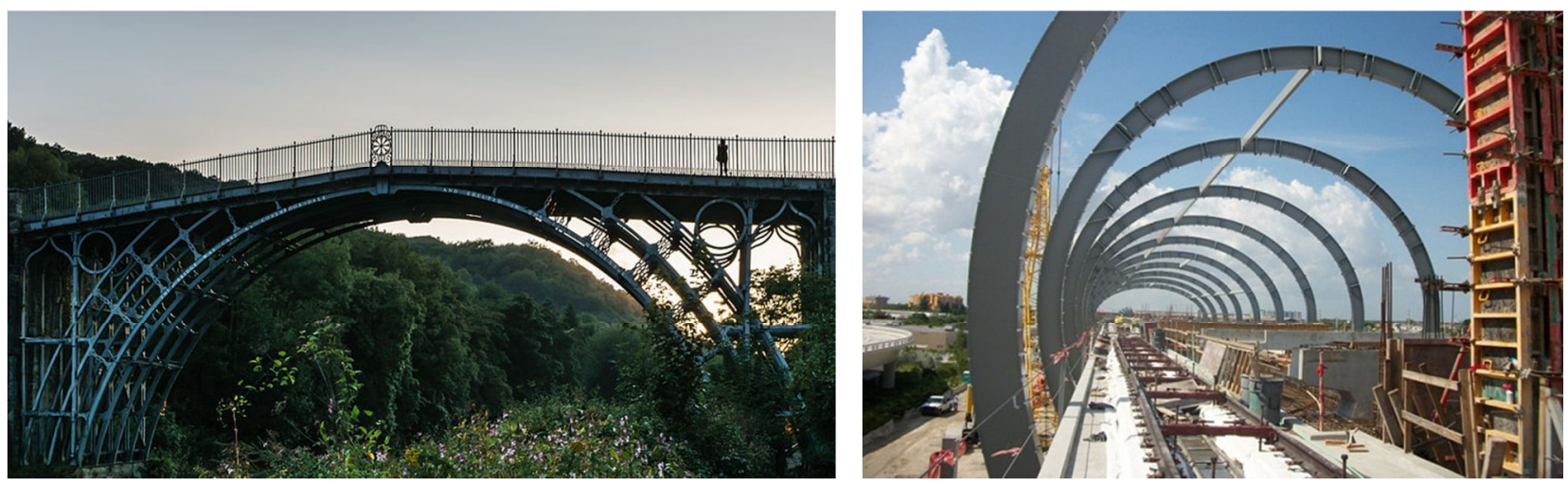

Slika 1.1 (a) Prvi lučni most od lijevanog željeza (b) Čelični eliptični lukovi u zračnoj luci Miami

Osim u građevinarstvu, lukove i zakrivljene gredne elemente pronalazimo u strojarstvu, zrakoplovnoj industriji itd. Osnovna razlika između pojma luk i zakrivljena greda je u stupnju zakrivljenosti, odnosno ako je radijus zakrivljenosti dovoljno mal da uzdužna krutost sačinjava sastavni dio pri prijenosu opterećenja, takve konstrukcije nazivamo lučnim konstrukcijama. Analiza takvih konstrukcija obično započinje njihovom klasifikacijom, koja definira pretpostavke primjenjive za daljini proračun. Osnovna podjela vezana je za vitkost, tj. odnos radijusa zakrivljenosti konstrukcije $R$ i visine poprečnog presjeka $b$ pa imamo: - debele lukove $(R / b<40)$, - umjereno debele lukove $(R / b=40)$ i tanke lukove $(R / b>40)$. Kod debelih lukova vrijedi pretpostavka da poprečni presjeci nakon deformacije ostaju ravni ali ne i okomiti na os luka. Do zakretanja poprečnog presjeka od normale dolazi uslijed postojanja poprečnih posmičnih deformacija. Smanjenje debljine dovodi do teorije tankih lukova koja omogućava zanemarivanje 
poprečnih posmičnih deformacija i pretpostavku da poprečni presjeci nakon deformiranja ostaju ravni i okomiti na os luka. Kako je već i navedeno, mehanizam nosivosti zakrivljenih greda (lukova) bitno ovisi o zakrivljenosti, pa se lukovi još dijele i prema kutu koji zatvaraju početna i krajnja os zakrivljenosti $\alpha$ na: - plitke lukove $\left(\alpha<40^{\circ}\right)$, - umjereno duboke lukove $\left(\alpha=40^{\circ}\right)$, duboke lukove $\left(40^{\circ}<\alpha<180\right)$ i vrlo duboke lukove $\left(\alpha>180^{\circ}\right)$.

U okviru ove radnje promatramo problem tankih ravninskih lukova, što znači usvajanje sljedećih pretpostavki: - os luka je ravninska krivulja, - vanjske sile djeluju u ravnini osi luka, poprečne posmične deformacije mogu biti zanemarene.

\subsection{LJUSKE KAO KONSTRUKCIJSKI ELEMENTI}

Ljuske u smislu konstruktivnog elementa zauzimaju značajno mjesto u građevinarstvu, strojarstvu, aeronautici i pomorskom inženjerstvu. Raširena upotreba ljusaka u građevinarstvu nastala je uslijed estetskih i konstruktivnih prednosti. Konstruktivne prednosti uključuju veliku nosivost $\mathrm{u}$ odnosu na težinu konstrukcije, tj. optimalnost oblika pri prenošenju opterećenja, te veliku krutost i zatvorenost prostora kojeg omeđuju (bez unutrašnjih podupora). Drugim riječima, ljuske su sposobne prenositi vanjska opterećenja zbog naravi svoje geometrije, što ih čini jačima i krućima od ostalih konstrukcijskih oblika. Mehanički gledano, ljuske prenose opterećenja pomoću poprečnih (savojnih) i ravninskih (membranskih) naprezanja. Ta podjela ih čini dominantno membranskim, savojnim ili miješanim ljuskama.

Primjeri ljusaka u građevinarstvu uključuju krovove velikih raspona, silose, betonske kupole i spremnike za tekućine (Slika 1.2, Slika 1.3).

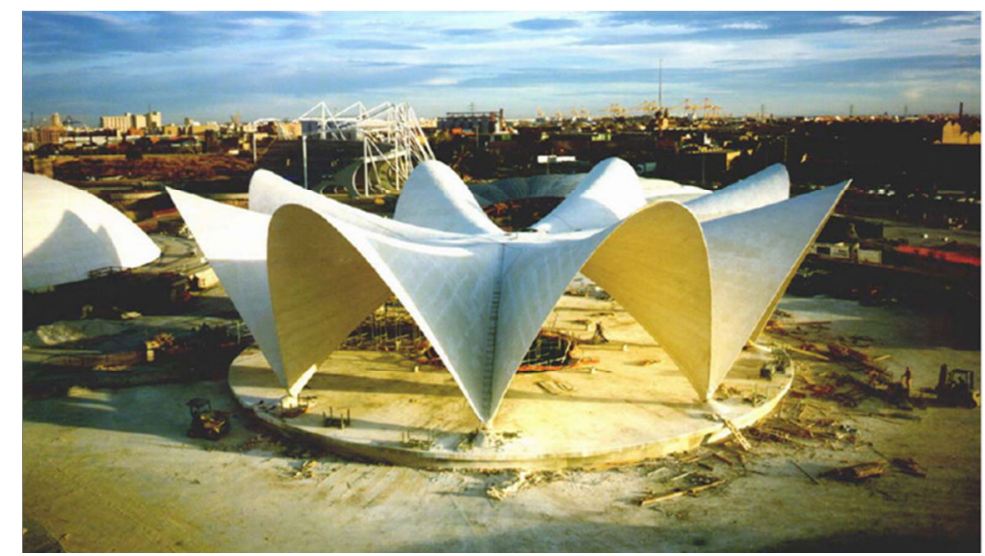

Slika 1.2 Gradnja L'Oceanogràfic vodenog parka u Valenciji 


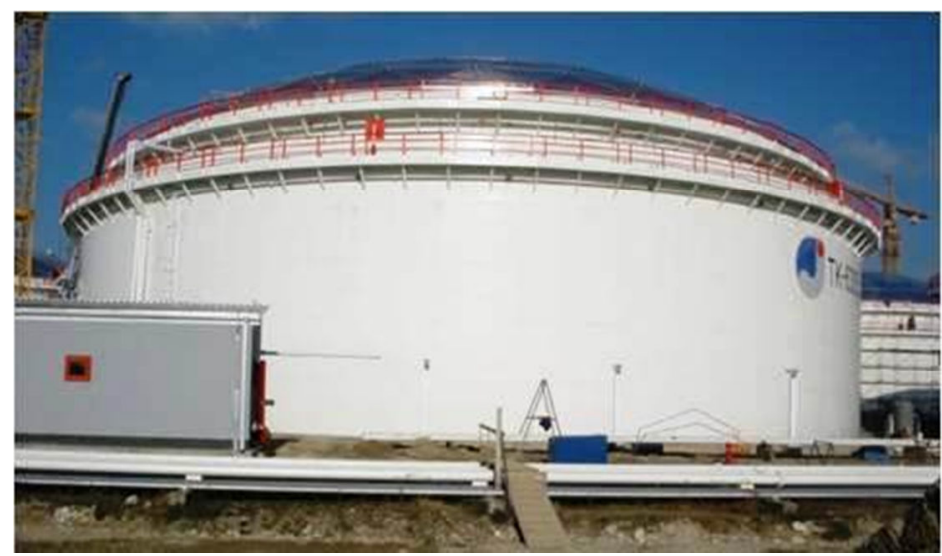

Slika 1.3 Silos za skladištenje naftnih derivata

Primjeri ljusaka u strojarstvu uključuju cjevovodne sustave, diskove turbina i razne tlačne spremnike. Zrakoplovi, projektili, rakete, brodovi i podmornice su primjeri ljusaka u aeronautici i podmorskom inženjerstvu. Ljuske također nalazimo u prirodi, u biljnom i životinjskom svijetu (kostur lubanje, ljuska jajeta itd.).

Ljuskom smatramo tijelo omeđeno dvjema zakrivljenim plohama čija je međusobna udaljenost mala u usporedbi sa ostalim dimenzijama. Mjesta koja leže na jednakim udaljenostima od dviju zakrivljenih površina nazivamo srednjom plohom, dok međusobnu udaljenost zakrivljenih ploha nazivamo debljinom ljuske (Crtež 1.1). Geometrija ljuske je u potpunosti određena geometrijom srednje plohe i debljinom $b . R_{1}$ i $R_{2}$ (Crtež 1.1) predstavljaju polumjere zakrivljenosti na okomitim stranicama segmenta ljuske.

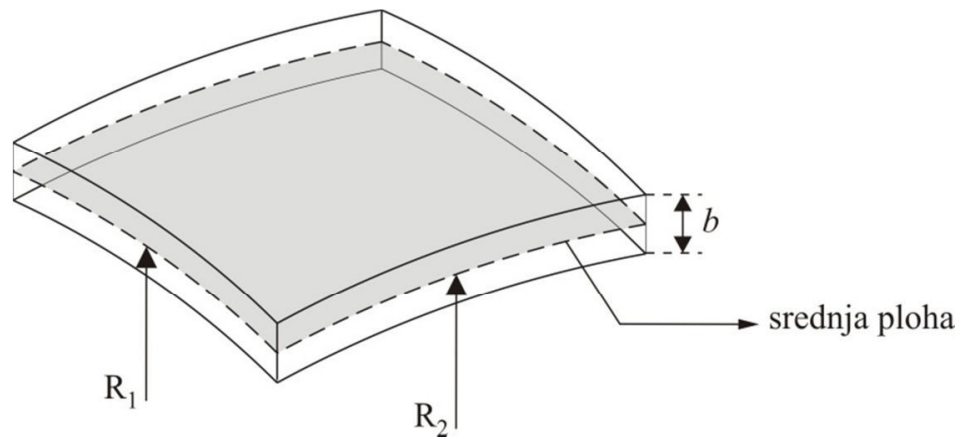

Crtež 1.1 . Segment ljuske

Potrebno je napomenuti da ukoliko $R_{1}$ i $R_{2}$ imaju najveći i najmanji polumjer gledano od svih okomitih stranica koje prolaze ovim segmentom, u tom se slučaju nazivaju glavnim polumjerima zakrivljenosti. Iz njih se onda definiraju glavne zakrivljenosti $\kappa_{1} \mathrm{i} \kappa_{2}$ kao

$$
\kappa_{1}=\frac{1}{R_{1}}, \quad \kappa_{2}=\frac{1}{R_{2}}
$$


Produkt glavnih zakrivljenosti $\kappa_{1} \kappa_{2}$ poznat je kao Gaussova zakrivljenost. Ljuske se često klasificiraju prema Gaussovoj zakrivljenosti, pa tako imamo ljuske s pozitivnom i negativnom Gaussovom zakrivljenošću, te one za koje je Gaussova zakrivljenost jednaka nuli. Ako promatramo ljuske prikazane na crtežu 1.2 vidljivo je da sferna ljuska ima $\kappa_{1}=\kappa_{2}$, kod konusne ljuske su $\kappa_{1}=0$ i $\kappa_{2} \neq 0$, dok ploče karakterizira $\kappa_{1}=\kappa_{2}=0$.

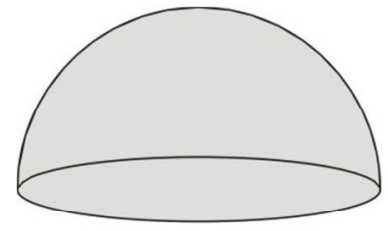

(a)

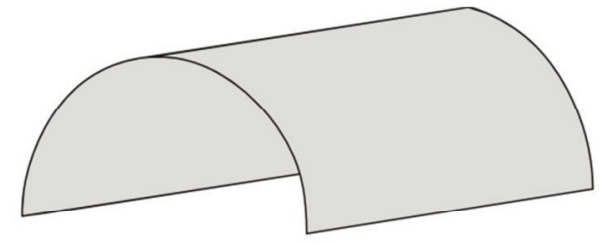

(b)

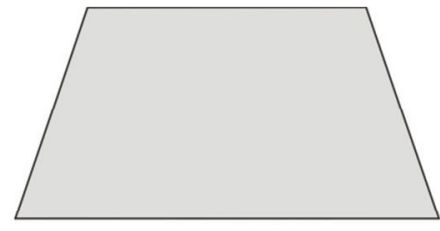

(c)

Crtež 1.2 (a) Sferna ljuska (b) Konusna ljuska (c) Ploča

Kod proračuna ljusaka postoje dvije glavne klase: - debele ljuske i - tanke ljuske. Ljuska se smatra tankom ako maksimalna vrijednost odnosa $b / R$ (gdje je $R$ radijus zakrivljenosti srednje plohe) može biti zanemarena u odnosu na jedinicu. Inženjerski promatrano, ljusku smatramo tankom ako zadovoljava sljedeći uvjet

$$
\max \left(\frac{\mathrm{b}}{\mathrm{R}}\right) \leq \frac{1}{20}
$$

Gornja nejednakost prilično grubo definira granicu između debelih i tankih ljusaka, koja u stvarnosti ovisi i o drugim geometrijskim parametrima poput rubnih uvjeta, opterećenja, itd. U praksi se većina ljusaka nalazi se unutar gore navedenog odnosa, što tankim ljuskama daje veliku praktičnu odliku.

Sukladno podjeli na tanke i debele ljuske, definirale su se i dvije glavne teorije pri proračunu konstrukcija ljuske: - Kirchhoff-Love i - Reissner-Mindln (Crtež 1.3). Kirchhoff-Love teorija zanemaruje utjecaj posmičnih deformacija po visini ploče na posmična naprezanja. Greška koja se javlja uslijed takvog zanemarivanja raste sa porastom debljine ploče, zbog čega se ova teorija još naziva i teorijom tankih ploča. Dakle, po toj teoriji promjena nagiba normale na srednju plohu uzrokovana je jedino progibom ploče (Crtež 1.3), odnosno $\phi_{\mathrm{x}}=0$. Reissner-Mindln-ova teorija uzima u obzir i zakretanje normale uslijed poprečnih posmičnih deformacija $\phi_{\mathrm{x}} \neq 0$ (Crtež 1.3), uslijed čega normala više nije okomita na srednju plohu, ali se također uzima kao linearna. 


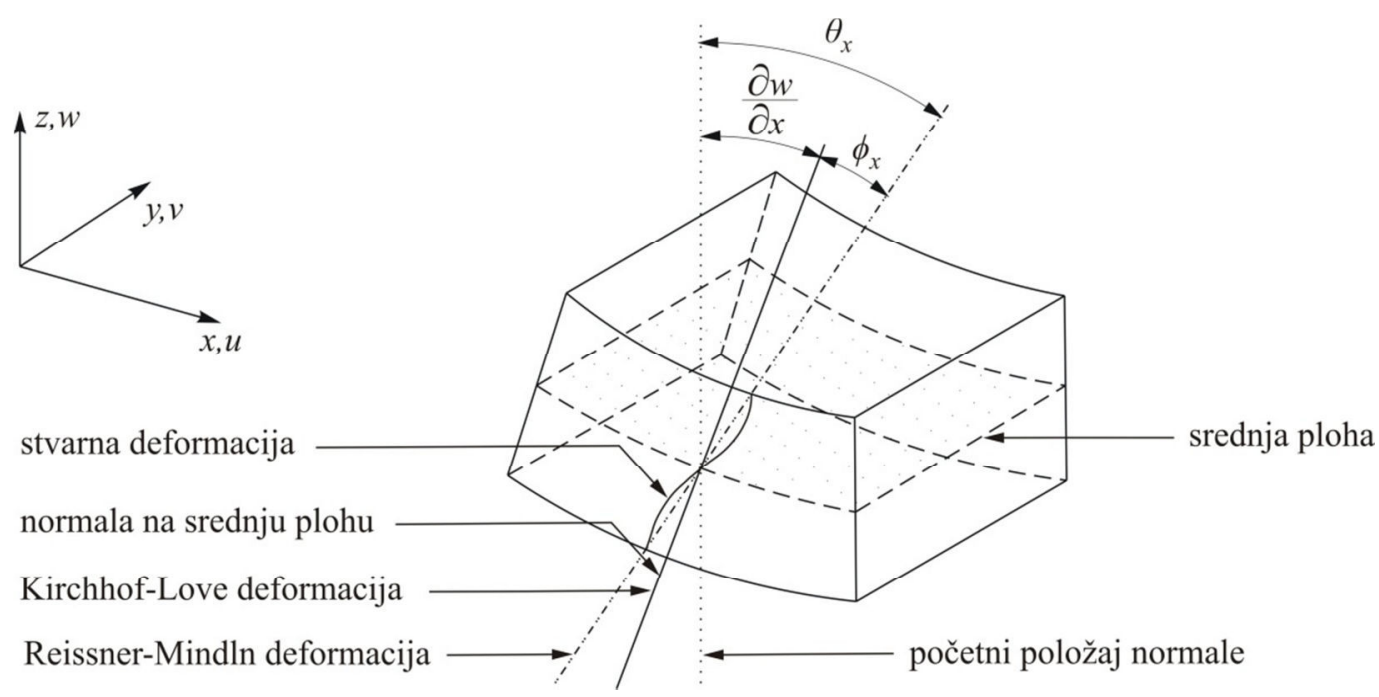

Crtež 1.3 Teorije pri proračunu konstrukcija ljuske

U okviru ove radnje promatramo problem tankih ljuska, što znači i usvajanje sljedećih pretpostavki proračuna:

- točke koje su prije deformiranja bile na pravcu okomitom na srednju površinu ljuske nalaze se i poslije deformiranja na pravcu okomitom na deformiranu srednju površinu (analogno Navier-ovoj hipotezi za grede),

- debljina ljuske je mala u odnosu na polumjere zakrivljenosti srednje ravnine ljuske,

- normalna naprezanja okomito na srednju površinu su tako mala da se mogu zanemariti, odnosno nema promjene pravog kuta između normale i bilo kojeg pravca na površini.

Mala debljina konstrukcije ljuske upućuje na njezinu djelotvornost pri prenošenju opterećenja. Efikasnost lučnog oblika leži u prenošenju poprečnih opterećenja uzdužnim silama, umanjujući time iznose poprečne sile i momenta savijanja. Ljuska tako uravnotežuje poprečna opterećenja pomoću tlačnih i vlačnih naprezanja raspoređenih jednoliko po debljini. Takvo stanje naprezanja nazivamo membranskim. Iako su u općenitom slučaju poprečna sila i momenti prisutni, učinkovitost oblika ljuske ovisi prvenstveno o membranskim naprezanjima. Izražen moment savijanja obično je lokaliziran na manjem području kod diskontinuiteta pri geometriji i opterećenju, npr. u blizini pridržanja.

Međutim, u određenim slučajevima upravo ta mala debljina postaje slabost. Ako promatramo uzdužne sile unutar ljuske, pri vlačnim naprezanjima dolazi do pune iskoristivosti materijala ravnomjerno po cijelom poprečnom presjeku. Pri tlačnim naprezanjima također dolazi do ravnomjerne raspodjele naprezanja poprečnom presjeku, no međutim moramo se pobrinuti da naprezanja budu iznosom manja od kritičnih naprezanja pri izbočivanju. Ta kritična naprezanja 
određena su debljinom ljuske: -što je tanja ljuska niži je iznos kritičnog naprezanja za izbočivanje. Taj problem može značajno umanjiti nosivost ljusaka, i treba nastojati da se pri dominantnom opterećenju što veći dio konstrukcije nađe pod vlačnim naprezanjem.

\subsection{MOTIVACIJA I CILJEVI RADA}

Tanke ljuske su jedan od najučinkovitijih i najraširenijih konstrukcijskih oblika. Uslijed naravi njihovog položaja na konstrukciji često su podložne raznim dinamičkim opterećenima (leteći projektili, udari vjetra...), što zahtjeva njihovu detaljnu dinamički analizu. Iako je dosad najrašireniji alat $u$ analizi konstrukcija ljusaka bila metoda konačnih elemenata (MKE), pokazalo se da ta metoda u kombinaciji sa najjednostavnijim tročvornim konačnim elementom posjeduje određena ograničenja [B5], [C5], [D9]. Pri smanjenju debljine ljuske u odnosu na njezinu duljinu posmični članovi počinju dominirati matricom krutosti i time uzrokuju nerealno povećanje krutosti poznato kao posmično blokiranje. Iako su se četverostranični konačni elementi pokazali puno bolji u prevladavaju problema posmičnog blokiranja, i posjeduju puno bogatije polje deformacija, trokutni konačni elementi su posebno zanimljivi zbog svoje računalne jednostavnosti i učinkovitosti pri opisivanju proizvoljne geometrije. Trokutasti tročvorni elementi su još uvijek pod stalnim razvojem u metodi konačnih elemenata, uzimajući u obzir problem posmičnog blokiranja [B13], [L6], [L9], [O7], [P11].

Nasuprot MKE, metoda diskretnih elemenata (MDE) razvila se kao rješenje za analizu diskretnih elemenata. Kombinirana metoda konačno-diskretnih elemenata (MKDE) proizlazi iz porodice metode diskretnih elemenata, te objedinjuje prednosti MKE i MDE. U okvirima ove metode omogućena je interakcija između bilo kojih diskretnih elemenata, s time da svaki od njih posjeduje svoju mrežu konačnih elemenata [M12]. Jednadžbe gibanja rješavaju se eksplicitno, u svakom vremenskom koraku, eksplicitnom metodom konačnih razlika. To se odvija u kombinaciji sa masama koncentriranim u čvorove, što znači da nema potrebe za sastavljanjem matrice masa ni matrice krutosti.

Danas glavni interes kod analize ljusaka obuhvaća smanjivanje računalnog obima na praktično primjenjivu razinu. Tom problemu može se pristupiti sa više stajališta. Neki od njih uključuju otklanjanje nedostataka na postojećim jednostavnim konačnim elementima, te razvoj novih konačnih elemenata koji omogućavaju što rjeđu diskretizaciju domene. Problemu također možemo pristupiti i intuitivnim kreiranjem novih numeričkih modela, usuglašenima sa trenutnim računalnim razvojima i prikladnima za opću analizu tankih ljusaka. Upravo iz tih razmatranja 
proizlazi glavna motivacija za izradu ove disertacije. Disertacija za cilj ima razvijanje numeričkog modela za simulaciju ponašanja tankih ljusaka pod dinamičkim opterećenjem, spajajući kombiniranu metodu konačno-diskretnih elemenata sa tročvornim trokutnim konačnim elementima. Očekuje se da bi ovaj numerički model mogao pomoći pri analizi dinamičkog ponašanja i stabilnosti konstrukcija ljuske, te služiti kao podloga za daljnju nadogradnju materijalnih nelinearnosti i udara, što je i omogućeno samim odabirom metode konačno-diskretnih elemenata.

Analiza lukova, iako u jednostavnijem kontekstu, u sebi sadrži mnoge poteškoće koje se mogu susresti pri analizi konstrukcija ljusaka [C15]. Upravo stoga, ako se modeliranje lukova izvrši na sličnim temeljima to može pružiti i uvid u ponašanje konstrukcija ljusaka. Ta ideja služila je kao motivacija za razvoji i verifikaciju numeričkog modela lukova, prije nego se pristupi analizi složenijih konstrukcija poput ploča i ljusaka. Zbog formulacijske jednostavnosti i računalne učinkovitosti odabrani su ravni dvočvorni konačni elementi.

Ciljevi ovog rada su sljedeći:

- Razvoj novog i originalnog algoritma za statičku, dinamičku i analizu stabilnosti grednih elemenata. Algoritam se bazira na dvočvornim konačnim linijskim elementima oslobođenima rotacije, i uzima u obzir linearno elastično ponašanje, velike rotacije, velike pomake i konačne deformacije. Model se bazira na eksplicitnoj integraciji jednadžbi gibanja u vremenu.

- Implementacija novorazvijenog algoritma za statičku, dinamičku i analizu stabilnosti tankih grednih elemenata u Yfdem otvoreni računalni program koji se bazira na MKDE.

- Validacija i primjena novorazvijenog računalnog programa u statičkoj, dinamičkoj i analizi stabilnosti tankih grednih i lučnih konstrukcija.

- Razvoj novog i originalnog algoritma za statičku, dinamičku i analizu stabilnosti tankih ploča i ljusaka. Algoritam se bazira na tročvornim konačnim elementima oslobođenima rotacije, i uzima u obzir linearno elastično ponašanje materijala, velike rotacije, velike pomake i konačne deformacije. Model se bazira na eksplicitnoj integraciji jednadžbi gibanja u vremenu.

- Implementacija novorazvijenog algoritma za statičku, dinamičku i analizu stabilnosti tankih ploča i ljusaka u Yfdem otvoreni računalni program koji se bazira na MKDE. 
- Validacija i primjena novorazvijenog računalnog programa u statičkoj, dinamičkoj i analizi stabilnosti tankih ploča i ljusaka.

- Razrada primjene i daljnjeg razvoja novih, predloženih modela.

\subsection{SADRŽAJ RADA}

Kako priroda ponašanja konstrukcija lukova vuče paralele sa ponašanjem konstrukcija ljusaka, u ovog sklopu rada razvijen je numerički model za analizu lučnih konstrukcija na temelju kojeg je poopčenjem sa linijske konstrukcije u plošnu razvijen numerički model za analizu ponašanja konstrukcija ljusaka. Predmet ovog rada bio je stoga razvoj i verifikacija numeričkih modela za analizu konstrukcija lukova i ljusaka zasnovanih na kombiniranoj metodi konačnodiskretnih elemenata. Modeli su implementirani u računalni program Yfdem koji se temelji na kombiniranoj metodi konačno-diskretnih elemenata.

Rad je podijeljen u osam poglavlja.

U prvom poglavlju predstavlja se tematika tankih lukova i ljusaka, njihova primjena, te potreba za dinamičkom analizom. Također, prikazana je motivacija za numeričko modeliranje takvih konstrukcija kombiniranom metodom konačno-diskretnih elemenata u kombinaciji sa najjednostavnijim konačnim elementima (dvočvorni ravni i trokutasti tročvorni konačni element). $\mathrm{Na}$ kraju su navedeni ciljevi rada i pregled poglavlja.

U drugom poglavlju obuhvaćen je pregled najraširenijih metoda pri analizi konstrukcija lukova i ljusaka, s posebnim naglaskom na modeliranje ljusaka pomoću trokutastih konačnih elemenata. Također su predstavljeni problemi koji se javljaju pri njihovom modeliranju, s težištem na problemu blokiranja. Navedene su i modifikacije kojima se ti problemi pokušavaju otkloniti. $\mathrm{Na}$ kraju je prikazan dosadašnji rad u modeliranju lukova i ljusaka koristeći kombiniranu metodu konačno-diskretnih elemenata.

U trećem poglavlju prikazane su osnove kombinirane metode konačno-diskretnih elemenata namijenjene za dinamičku analizu lukova i ljusaka. Svaki luk/ljuska predstavlja diskretni element diskretiziran s mrežom konačnih elemenata koja omogućuje njihovu deformabilnost. Shodno tome prikazani su pristupi detekcije kontakata i interakcije diskretnih elemenata, te proračun sila koje nastaju uslijed deformabilnosti pripadajućih konačnih elemenata, skupa sa vremenskom diskretizacijom. 
U četvrtom poglavlju predstavljen je numerički model za statičku i dinamičku analizu lukova. Detaljno je prikazana diskretizacija konstrukcije te mehanizmi prijenosa uzdužnih i savojnih deformacija. U sklopu ovog poglavlja također je provedena verifikacija modela za statičku i dinamičku analizu lukova, te njegova primjena na problem stabilnosti lukova.

U petom poglavlju predstavljen je novi numerički model za statičku i dinamičku analizu ljusaka. Detaljno je prikazana diskretizacija konstrukcije te mehanizmi za prijenos membranskih i savojnih deformacija. Opisane su dvije varijante proračuna savojne krutosti, od kojih je za daljnju primjenu usvojena samo jedna varijanta. Provedena je verifikacija razvijenog algoritma za statičku i dinamičku analizu ljuska, te njegova primjena na analizu konačnih rotacija i pomaka.

U šestom poglavlju prikazani su primjeri primjene razvijenih modela. Primjena modela lukova ilustrirana je primjerom čeličnog luka podloženog potresnom opterećenju. Primjena modela ljusaka ilustrirana je analizom točke gubitka stabilnosti kod triju tipskih problema, tj. grede, ploče i cilindra.

U sedmom poglavlju iznijeti su najvažniji zaključci ovog rada kao i pravci daljnjih istraživanja, temeljeno na rezultatima prikazanima u radnji.

Osmo poglavlje sadrži pregled korištene literature. 


\section{OSVRT NA MODELIRANJE KONSTRUKCIJA LUKOVA I LJUSAKA}

Analiza zakrivljenih konstrukcija izvodi se, u većini slučajeva, primjenom numeričkih metoda. Postoji cijeli niz praktičnih inženjerskih problema za koja analitičko rješenje predstavlja matematički jako složen problem. Kada su nam i poznata, rješenja izvedena iz teorije odnose se samo na specijalne, najčešće osnosimetrične geometrijske oblike sa posebnim slučajevima opterećenja. Shodno tome pribjegavamo numeričkim metodama koja točno rješenje opisuju samo u diskretnim točkama, tzv. čvorovima. Takav pristup omogućuje provedbu analize uz postizanje zadovoljavajuće točnosti.

Kao najrašireniji alat za analizu zakrivljenih konstrukcija pokazala se metoda konačnih elemenata. U okvirima te metode potrebno je razumjeti ponašanje pojedinačnog konačnog elemenata, kojim se dalje opisuje zakrivljena geometrija i provode uvjeti kontinuiteta između elemenata skupa sa rubnim uvjetima. Novija istraživanja zakrivljenih konstrukcija također obuhvaćaju metodu rubnih elemenata, bezmrežne metode te kombiniranu metodu konačnodiskretnih elemenata. U daljnjem osvrtu na modeliranje zakrivljenih konstrukcija detaljnije je približen dio o ravnim dvočvornim i trokutastim tročvornim konačnim elementima, budući da su isti primjenjivani u ovom radu. 


\subsection{METODA KONAČNIH ELEMENATA}

\subsubsection{Modeliranje lukova}

Zakrivljene grede i lukovi opterećenja prenose interakcijom savojne i aksijalne krutosti, što predstavlja mehanički složen problem. Pri njihovom opisivanju konačnim elementima temeljenima na metodi pomaka, polje pomaka opisivalo se polinomima različitih stupnjeva. Ti polinomi odabrani su na način da zadovoljavaju uvjete poput stanja konstantnih deformacija i pomake krutog tijela. Kod zakrivljenih konačnih elemenata treba biti zadovoljen i dodatni uvjet nerastezljivosti pri savijanju, što je posebno bitno pri analizi dubokih i tankih lukova. Ukoliko taj uvjet nije zadovoljen, savojna naprezanja rezultirat će dominantno aksijalnim odgovorom konstrukcije umjesto savojnog nerastezljivog ponašanja. Taj fenomen, poznat kao membransko blokiranje, podcjenjuje savojne deformacije i precjenjuje savojne frekvencije. Nadalje, klasični izoparametrijski elemenata nižeg reda na dubokim i tankim lukovima pokazuju fenomen posmičnog blokiranja. Posmično blokiranje iskazuje se nerealnom procjenom posmične energije $u$ odnosu na savojnu, što također rezultira nerealno krutim ponašanjem. Potrebno je još naglasiti kako odabir konačnog elementa ovisi o vitkosti konstrukcije i kutu koji zatvaraju početna i krajnja os zakrivljenosti luka/grede. Najjednostavniji element korišten pri analizi predmetnih konstrukcija je ravni dvočvorni element.

U samim počecima modeliranja lukova bilo je potrebno otkloniti gore navedene efekte. Ashwell i dr. [A9] su, koristeći pretpostavku konstantnih membranskih i linearnih savojnih deformacija, predstavili dvočvorni element oslobođen membranskog blokiranja. Dawe [D1], [D2] je analizirao različite dvočvorne konačne elemente koji su varirali u stupnju polinoma za opisivanje uzdužnih i poprečnih pomaka. Zaključio je da polinom petog stupnja kod uzdužnih i kod poprečnih pomaka bilježi brzu konvergenciju i dobre rezultate, čak i za tanke lukove sa grubljom mrežom. Meck [M3] je pokazao da se pogreška kod upotrebe klasičnih polinomnih funkcija za opisivanje pomaka može eliminirati povezivanjem poprečnih i uzdužnih pomaka. Pokazao je kako kod tankih i dubokih lukova treba nužno biti zadovoljen uvjet nerastezljivosti pri savojnim deformacijama, jer inače dolazi do problema blokiranja. U samim počecima, reducirana integracija nametnula se kao rješenje problema blokiranja [P14], [S13]. Iako je postignuto poboljšanje u točnosti, reducirana integracija uslijed niskog ranga matrice krutosti dovodi do neželjenih zero-energy modova, Također, reducirana integracija rezultira i odvajanjem savojnouzdužnog djelovanja, što je jedna od osnovnih pretpostavki kod zakrivljenih elemenata. Tessler i 
Spiridigliozzi [T7] su predložili tzv. penalty relaxation pristup za oslobođenje od problema blokiranja.

Uz razvoj klase tročvornih izoparametrijskih elemenata sa kvadratnom interpolacijom uzdužnih i poprečnih pomaka također se pojavio problem blokiranja. Prathap i Babu [P13] predstavili su tročvorni posmično deformabilni element sa pristupom dosljednosti polja deformacija. Taj pristup pronalazi nedosljednosti u posmičnom i membranskom polju deformacija (što je uzrok blokiranja i smanjenja točnosti), te ih zatim otklanja primjenom modificiranih funkcija oblika. Kasnije su Lee i dr. [L7] primijenili pristup dosljednosti polja deformacija na dvočvorni konačni element. Razdvajali su poprečne pomake na savojni i posmični dio, koristeći posmična ograničenja, te uzdužnu zakrivljenost usuglašenu sa membranskim poljem. Lee i Sin [L3] su predstavili element koji zakrivljenost interpolira preko tri čvora, a posmičnu i uzdužnu deformacijsku energiju uračunava preko jednadžbi ravnoteže. Tročvorna zakrivljenost se, preko transformacijske matrice, reducira u dvočvornu konfiguraciju. Choi i Lim [C8] razvili su dvočvorni i tročvorni posmično deformabilni element temeljen na pretpostavljenim konstantnim (za dvočvorni) i linearnim (za tročvorni) poljima deformacije.

Friedman i Kosmatka [F11] predstavili su ravni dvočvorni posmično deformabilni element sa kubnim polinomom za raspodjelu poprečnih pomaka i polinomom četvrtog stupnja za kut savojne rotacije. Polinomi su međusobno nezavisni, i zadovoljavaju dvije homogene diferencijalne jednadžbe vezane za debele grede. Ista metodologija je kasnije primijenjena na dvočvorni zakrivljeni element [F10]. Krishnan i dr. [K9], [K10] su uspoređivali učinkovitost dvočvornog zakrivljenog elementa. Uspoređivali su element sa tri stupnja slobode u čvoru (uzdužni i poprečni pomak, te zaokret) sa posmično deformabilnim elementom sa četiri stupnja slobode (dodavanje stupnja poprečne posmične deformacije). Usporedbe su proveli za statičku i slobodnu dinamičku analizu. Litewka i Rakowski [L17] su također predstavili dvočvorni zakrivljeni element sa šest stupnjeva slobode za analizu tankih i debelih elemenata. Polazište im je bio konačni element sa konstantnom zakrivljenošću i 18 točnih funkcija oblika, dobivenih kao rješenje diferencijalne jednadžbe luka sa konstantnom zakrivljenošću, prikazanih u [L18]. U [L17] su te trigonometrijske funkcije oblika prikazane u obliku exponencijalnog reda, sa koeficijentima koji ovise o geometrijskim i fizikalnim svojstvima elementa. Dalje su iz deformacijske energije odredili matricu krutosti elementa.

Raveendranath i dr. [R2] predstavili su dvočvorni posmično deformabilni element nastao pretpostavljenim poljem pomaka. Za polje poprečnog pomaka predložen je kubni polinom. Koristeći ravnotežne jednadžbe za silu-moment i moment-posmik dobiveni su uzdužni pomaci i 
kut rotacije. Dobiveno polje pomaka dosljedno je sa poprečnim pomacima, a element je oslobođen od membranskog i posmičnog blokiranja. Kasnije su, na sličnom principu, Raveendranath i dr. [R3] predstavili tročvorni posmično deformabilni element. Krenuli su od pretpostavke polinoma četvrtog stupnja za polje savojnih rotacija, preko čega su dalje izraženi uzdužni i poprečni pomaci te kut rotacije poprečnog presjeka.

Također je potrebno spomenuti mješovite i hibridne formulacije konačnih elemenata, koje za zakrivljene konstrukcije pokazuju znatne prednosti u odnosu na metodu pomaka. Reddy i Volpi [R5] su predstavili usporedbu rezultata standardne formulacije sa punom integracijom i mješovite formulacije sa reduciranom integracijom za kružne probleme. Zaključili su kako je kod prvog pristupa konvergencija ili ispod zadovoljavajuće razine ili uopće ne postoji, dok se kod drugog pristupa konvergencija poklapa sa onom predviđenom prema teoriji. Saritas [S5] je predložio mješoviti dvočvorni zakrivljeni element temeljen na Hu-Washizu varijacijskom principu. Umjesto pomaka, oblikovnim funkcijama opisana su naprezanja. Element je oslobođen blokiranja i može vršiti materijalno linearnu i nelinearnu analizu. Također je pokazao kako je za linearno rješenje dovoljno koristiti samo jedan konačni element po rasponu.

Budući da se konvencionalni mješovito hibridni elementi sa nižim redom interpolacijskih funkcija nisu pokazali potpuno učinkovitim pri savojnom djelovanju i višim vibracijskim oblicima, pojavile su se formulacije sa uvođenjem dodatnih unutrašnjih bezčvornih stupnjeva slobode sa pretpostavkama za polje pomaka. Zhang i Di [Z1] su predstavili dva dvočvorna zakrivljena posmično deformabilna elementa od kojih je jedan temeljen na standardnoj metodi pomaka (princip potencijalne energije) a drugi na mješovito hibridnoj formulaciji sa HellingerReissner varijacijskim principom. Standardni element koristi kubne poprečne pomake i polinom četvrtog stupnja za opisivanje kuta rotacije, te unutrašnje bezčvorne funkcije pomaka koje osiguravaju potrebnu vezu između rotacije i pomaka za eliminiranje problema blokiranja. Mješovito hibridni element je temeljen na naprezanjima. Pristup uporabe unutrašnjih parametara pomaka se pokazao uspješnim, a oba elementa su oslobođena od problema blokiranja. Kim i Park [K5] su također predstavili dvočvorni zakrivljeni element temeljen na Hellinger-Reissner varijacijskom principu i dodatnim bezčvornim stupnjevima slobode. Proučavali su utjecaj reda unutrašnjih bezčvornih stupnjeva slobode pomaka i oblika matrice krutosti na rezultate mješovito hibridnih elemenata kod statičke i dinamičke analize. Neki od ranijih radova sa mješovitom hibridnom formulacijom uključuju [S4], [D8], [K4].

Wo i Chiang [W9] predstavili su tanki dvočvorni element gdje su eksplicitne funkcije oblika iz postojeće literature zamijenili jednostavnijim implicitnim funkcijama predstavljenima $u$ 
matričnom obliku. Također su, osim zakrivljenog elementa, predstavili i ravni hibridni element sa koncentriranim masama. Navedeno pojednostavljenje funkcija oblika nije značajno uzrokovalo na pad točnosti elementa. Dodavanjem torzijskog i posmičnog stupnja slobode zakrivljenom elementu, Wu i Chiang [W10] su također predstavili zakrivljeni element za izračun slobodnih vibracija okomito na ravninu luka. Također su pokazali kako izračun slobodnih frekvencija sa pristupom koncentriranih masa može davati rezultate jako slične onima sa pristupom raspodijeljenih masa. Leung i Zhu [L11] su predstavili nekoliko Fourier $p$-elemenata za ravninsku vibraciju tankih i debelih zakrivljenih greda. Uvođenjem dodatnih stupnjeva slobode, preko sinusa u Fourierovim trigonometrijskim funkcijama, izbjegnut je problem blokiranja te povećana konvergencija i stabilnost elementa.

Saffari i Tabatabaei [S2] su također poput [L3] predstavili konačni element koji umjesto polja pomaka interpolira zakrivljenost, i to pomoću trigonometrijskih funkcija. Da bi se uračunali rubni uvjeti, također je korištena matrica transformacije između zakrivljenosti i vektora pomaka. Problem blokiranja eliminiran je ravnotežnom jednadžbom minimuma potencijalne energije, napisanom preko komponenata pomaka. Kasnije su Saffari i dr. [S3] proširili taj pristup na slobodnu dinamičku analizu kružnog luka. Većina navedenih elemenata usredotočena je na slobodne dinamičke i statičke analize. Njihova prikladnost za dinamičke i geometrijski nelinearne analize u većini slučajeva nije istraživana. Pan i Liu [P2] predstavili su zakrivljeni posmično deformabilni element temeljen na izoparametrijskoj formulaciji i nelinearnoj vezi deformacijapomak, uz dinamičke jednadžbe napisane preko principa virtualnog rada.

U posljednja dva desetljeća došlo je do razvoja konačnih elemenata oslobođenih rotacije, tzv. RF elemenata. Glavna karakteristika RF elemenata je pojednostavljenje problema izbacivanjem rotacijskih stupnjeva slobode uz povećanje interpolacijske domene izvan područja integracijske domene. Drugim riječima, pri interpolaciji pomaka konačni element promatramo skupa sa njemu susjednim konačnim elementima. Iako je težište ideje RF elemenata na razvoju trokutastih elemenata za analizu ljusaka, u posljednje vrijeme predložili su se i RF gredni elementi. Phaal i Calladine [P9] su razvili gredni RF element pretpostavljajući kvadratnu raspodjelu poprečnih pomaka, uz konstantnu zakrivljenost dobivenu promatranjem triju susjednih čvorova kao što je prikazano na crtežu 2.1 (a). Flores i Oñate [F9] predstavili su RF element za nelinearnu analizu greda i rotaciono simetričnih ljusaka, s posebnim naglaskom na zakrivljenim i razgranatim gredama. Konačni elementi smatraju se ravnima, i nad njima se određuju normale, kako je prikazano na crtežu 2.1 (b). Zakrivljenosti u čvorovima 2 i 3 određene su na temelju promjene položaja u normalama, kako je opisano u [F9]. Oñate i Zarate [O6] su kasnije proširili 
taj pristup na debele grede dodavanjem dodatnih stupnjeva slobode koji opisuju poprečnu posmičnu deformaciju.

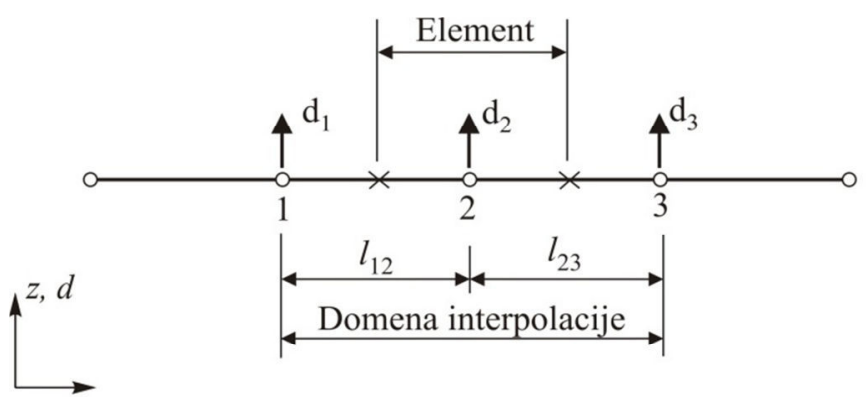

(a)

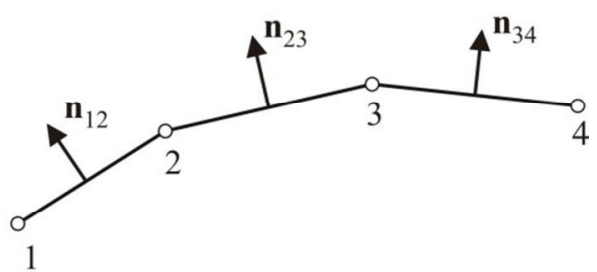

(b)

Crtež 2.1 (a) Tri uzastopna čvora ravnog elementa (b) Četiri uzastopna čvora zakrivljenog elementa [Z4]

Battini [B7] je predložio RF gredni korotacijski element, odnosno element gdje su pomaci razloženi na dio uslijed krutog tijela i uslijed deformacije. Konačni element se ponovo promatra preko četiri čvora, dva na elementu skupa sa najbližim lijevim i najbližim desnim čvorom. Zhou i Sze [Z3] su predstavili proširenje ravnog elementa od Phaal i Calladine [P10] na zakrivljeni element, i time omogućili njegovu primjenu na zakrivljene grede. Također su primijenili korotacijski pristup. Ovaj jednostavni element pokazao se iznimno učinkovitim pri analizi geometrijski nelinearnih problema.

\subsubsection{Modeliranje ljusaka}

Analiza ljuski obično se provodi na način da se čvorovi konačnih elemenata rasporede po srednjoj plohi ljuske i u svakom čvoru definira pet stupnjeva slobode, tri pomaka i dva zaokreta normale oko tangenti na srednju plohu (Crtež 2.2). Kada bi se takvi elementi ljuske kombinirali sa drugim tipovima elemenata dolazilo bi do nekompatibilnosti zaokreta u dodirnim čvorovima, a time i numeričkih poteškoća u proračunu. Shodno tome atraktivno je uvođenje rotacije normale na srednju plohu kao šestog stupnja slobode, tzv. "stupanj slobode bušenja".

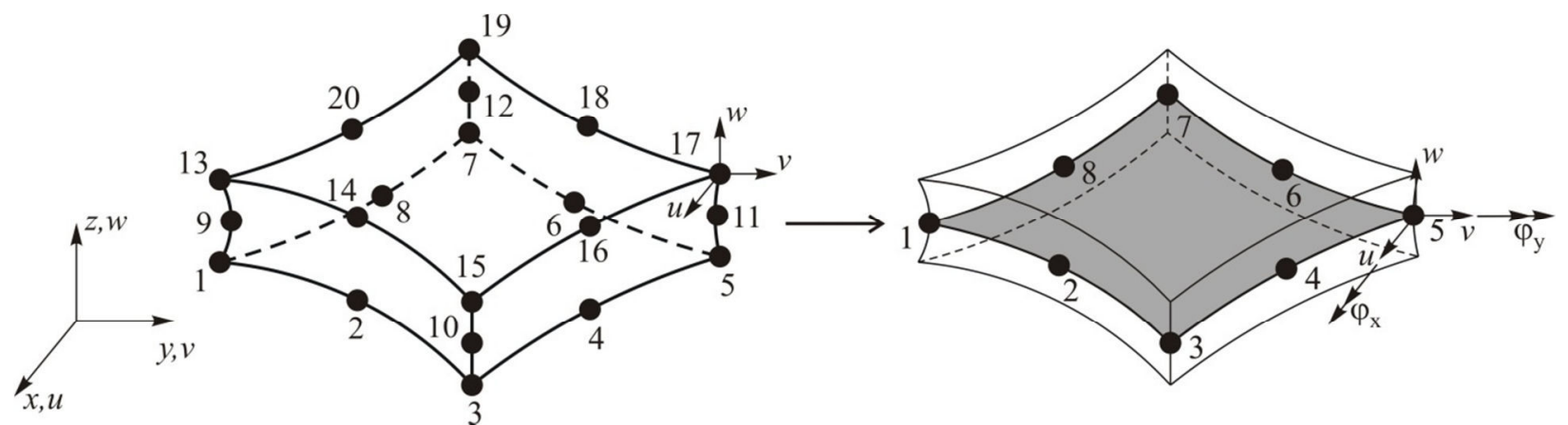

Crtež 2.2 20-čvorni prostorni i 8-čvorni element ljuske [G3] 
Postoje tri osnovna pristupa pri odabiru konačnog elemenata za analizu ljusaka:

- zakrivljeni elementi formulirani na temelju različitih teorija ljusaka,

- degenerirani izoparametrijski elementi izvedeni iz prostornih elemenata (Crtež 2.2),

- ravni elementi izvedeni kombinacijom membranskih i savojnih elemenata (Crtež 2.3).

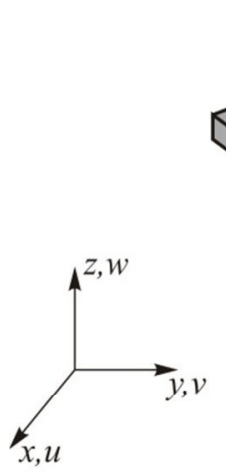

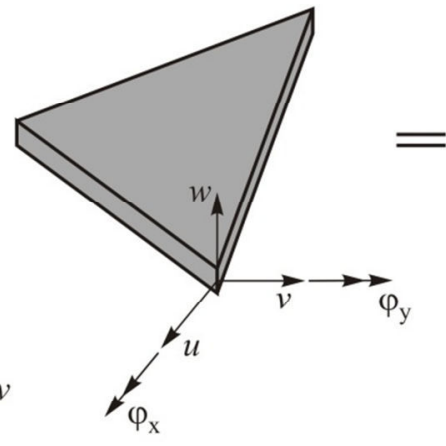

Element ljuske

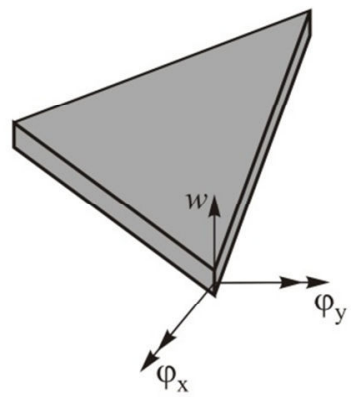

Element ploče

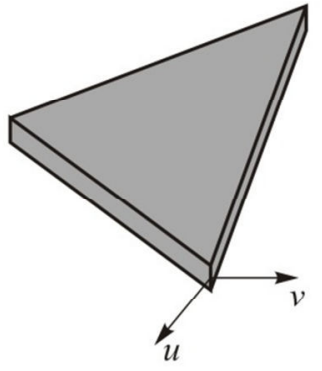

Membranski element

Crtež 2.3 Trokutasti element ljuske sa pet stupnjeva slobode u čvoru

Zakrivljene elemente formulirane na temelju različitih teorija ljusaka karakterizira jako složena formulacija. Također ih prati i osjetljivost na deformacije pri pomaku krutog tijela. Jednostavnijim pristupom pokazali su se elementi izvedeni degeneriranjem izoparametrijskih trodimenzionalnih elemenata. Taj pristup je posljednjih desetljeća dominirao računalnom analizom ljuska. Uzrok tome pronalazimo u jednostavnosti njihove formulacije i dosta dobrim rezultatima usprkos problemima poput onih uzrokovanih blokiranjem. Temeljeni su na ReissnerMindlin pretpostavkama, a mogu se primijeniti jednako za tanke kao i za debele ljuske. Iako imaju jednostavnu formulaciju, pokazali su se računalno zahtjevnima pri nelinearnim proračunima, što im donekle otežava primjenu, posebno kod materijalno nelinearnih problema. Opširniji prikaz ovih elemenata može se pronaći u knjigama od Hughes-a [H8], Bathe-a [B5], te Chapelle i Bathe [C5].

Ravni elementi za analizu ljusaka koriste se od samih početaka primjene MKE. Njihova formulacija nastala je kombiniranjem ravninskih membranskih elemenata sa elementima korištenima pri analizi ploča (Crtež 2.3). Shodno tome, kod ovih elemenata dolazi do odvojenog promatranja membranskog i savojnog deformiranja, uz primjenu principa superpozicije. Jednostavnost takve formulacije uz zadovoljavajuću točnost osigurava ravnim elementima kontinuiranu upotrebu kod analize ljusaka. Membranske sile nastaju isključivo kao posljedica tangencijalnih komponenti pomaka, dok su momenti savijanja i uvijanja povezani samo s komponentom u pravcu normale na srednju plohu. Drugi nedostatak im je približnost opisivanja 
zakrivljene geometrije ravnom diskretizacijom, zbog čega je potrebno koristiti gustu mrežu konačnih elemenata. U primjeni su ravni trokutni i pravokutni elementi.

Glavnu zapreku razvojima konačnog elementa za analizu konstrukcija ljuske predstavlja efekt posmičnog blokiranja [B5], [D9], [C5]. Efekt se manifestira na način da konvergencija rješenja drastično slabi kako se debljina ljuske smanjuje. Drugim riječima, kod određenih odnosa debljine i duljine ljuske aproksimacija konačnim elementima ne može dovoljno dobro opisati polje pomaka uslijed savijanja. Rješenja su se pojavila u obliku reducirane i selektivne integracije, te hibridnih i mješovitih formulacija. Budući da četverostranični elementi imaju jednostavniji koordinatni sustav i bogatije polje deformacija lakše je pronaći elemente tog tipa koji premošćuju fenomen blokiranja. Četverostranični konačni elementi bilježe bolju konvergenciju u odnosu na trokutaste elemente, te je radi toga napravljeno puno više istraživanja i ima puno više rezultata vezano za korištenje tog tipa elementa. No međutim, u slučajevima složene geometrije ovi elementi postaju previše iskrivljeni i umjesto njih se pribjegava upotrebi trokutastih konačnih elemenata. Pravokutnim elementima moguće je opisati cilindrične oblike i različite prostorne pločaste konstrukcije, dok su trokutasti elementi prikladni i kod diskretizacije dvostruko zakrivljenih ljusaka.

\subsubsection{Trokutasti konačni elementi pri modeliranju ljusaka}

(a) Trokutasti konačni elementi za opisivanje membranskih problema

Najjednostavniji elementi za opisivanje membranskog dijela naprezanja su trokutasti element sa konstantnim deformacijama (CST) i linearnim deformacijama (LST) [C15]. CST je najjednostavniji membranski element uopće. Sastoji se od tri čvora sa dva slobodna pomaka u ravnini elementa i linearnom raspodjelom pomaka unutar elementa (crtež 2.4(a)). LST [H8] sadrži šest čvorova, tri na krajevima stranica i još tri, po jedan na polovici svake stranice, te kvadratnu raspodjelu pomaka unutar elementa (crtež 2.4(b)). Unatoč tome što LST ima superiornije karakteristike u odnosu na CST, CST se uslijed bolje kompatibilnosti sa elementima ploča češće nalazi u upotrebi.

Glavni nedostatak navedenih elementa je odsutnost stupnja slobode bušenja, uslijed čega dolazi do problema singularnosti. Prvi trokutasti membranski element sa stupnjem slobode bušenja razvijen je od Allman-a [A3] i poznat je kao Allmanov trokut. Iako je formulacija Allmanovog trokuta jednostavna, pokazalo se da također podliježe od problemu singularnosti. Naime, singularnost se dogodi kada su čvorni pomaci jednaki nuli a čvorne rotacije identične. 


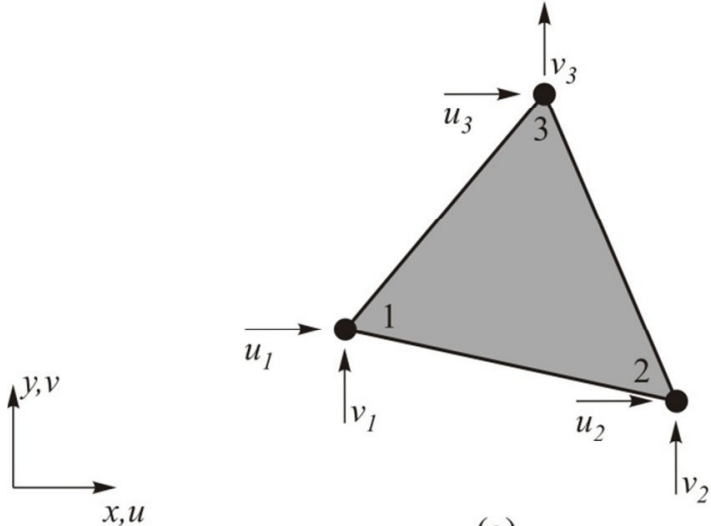

(a)

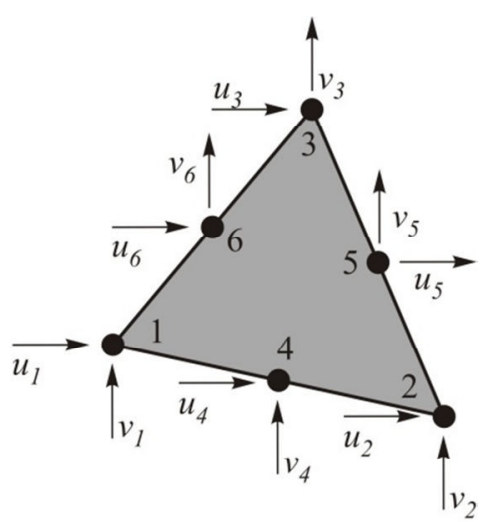

(b)

Crtež 2.4 (a) CST konačni element (b) LST konačni element

Allman je kasnije razvio i generalizaciju svog trokuta opisanu u [A4]. U toj formulaciji ravninski su pomaci opisani kubnim polinomom, a ako se zanemare članovi trećeg reda dolazi se do klasičnog Allmanovog trokuta. Cook je dalje dokazao da se Allmanov element može izvesti iz LST elementa na način da se pomaci na sredinama stranica povežu sa pomacima i rotacijama na krajevima [C13]. Još jedan uspješni trokutasti membranski element sa stupnjem slobode bušenja razvili su Bergan i Fellipa [B10] na temelju [B11]. Carpenter i dr. [C2] razvili su membranski element sa poljem pomaka identičnom Allmanovom trokutu, ali uz korištenje jedne točke integracije za izračun matrice krutosti. Kao rezultat reducirane integracije dolazi do tzv. "spurious zero energy modes", koji su otklonjeni koristeći stabilizacijsku shemu od Fish i Belytschko [F7]. To je učinjeno dodajući dodatne zakonitosti u vezu deformacije i pomaka, tako da se nulti modovi onemoguće. Cook je također predložio stabilizacijsku shemu [C14] u kojoj su dvije matrice dodane u matricu krutosti Allmanovog elementa sa jednom točkom integracije.

Gore predloženi konačni elementi temeljeni su na metodi pomaka, koja sa sobom vuče nedostatke detaljnije opisane u sljedećem poglavlju. Shodno tome, došlo je do razvoja konačnih elemenata temeljenih na hibridnim i mješovitim formulacijama. Cook [C14] je predstavio ravni trokutasti element koristeći hibridni pristup temeljen na nezavisnim naprezanjima u elementu i pomacima uzduž granice elementa. Hughes and Bezzi [H7] istraživali su varijacijske principe koji dopuštaju odvojena polja rotacija, što vodi membranskim elementima sa stupnjem slobode bušenja. To je najprije primijenjeno na četverostraničnim konačnim elementima [I1], [I3]. U seriji napravljenoj od tri dijela Alvin i dr. [A5], Felippa i Militello [F6] i Felippa i Alexander [F5] predstavili su visoko učinkoviti membranski trokutasti element sa rotacijom koristeći produženu formulaciju (EFF) i metodu pretpostavljenih devijatorskih deformacija (ANDES). Felippa je također objavio [F3] gdje uspoređuje membranske konačne elemente sa rotacijskim stupnjem slobode i pokazuje kako optimalni element koristi ANDES formulaciju. Famjan [F2] je koristeći 
princip minimuma potencijalne energije predstavio membranski trokutasti element sa stupnjem slobode bušenja i dvije matrice krutosti: čista matrica krutosti izvedena iz izduženja stranica elementa i globalna matrica krutosti ovisna o čvornim pomacima. Taj princip se pokazao učinkovitim pri nelinearnoj analizi. Tian i Yagawa [T9] pokazali su da matrica krutosti Allmanovog trokuta koja je originalno izračunata od LST može izvesti učinkovitije iz CST, i predstavili njezino pojednostavljenje. Huang i dr. [H6] također su razvili element modifikacijom Allmanovog trokuta, ali oslobođen od tzv. spourious energy modes.

(b) Trokutasti konačni elementi pri modeliranju ploča

Za razliku od membranskih problema, kod savijanja ploča postoji raznolikiji izbor konačnih elemenata. Bazeley i dr. [B8] razvili su prvi nekonformni trokutasti element koji, iako je bilježio bolje rezultate od konfornog elementa, nije posjedovao punu konvergenciju. Autori su došli do zaključka kako je nužan i dovoljan uvjet za konvergenciju nekonformnog elementa njegova mogućnost iskazivanja konstantnih deformacija kod neizmjerno malih elemenata. Taj postupak provjere, kasnije nazvan patch testom, ustalio se kao standardni postupak testiranja konačnog elementa. Skupina konačnih elemenata biva podvrgnuta konstantnim deformacijama i prati se da li njihovo ponašanje odgovara konstitutivnom zakonu i egzaktnim naprezanjima.

Morley [M9] je predstavio nekonformni trokutasti element sa kvadratnom raspodjelom pomaka izraženom preko progiba u krajnjim rubnim čvorovima i nagiba na sredinama rubnih stranica elementa. Morleyev element je pokazao dobro opisivanje momenta savijanja kod ploča. U samim počecima Baotz i dr. [B6] proglasili su diskretni Kirchhoffov element (DKT) temeljen na metodi pomaka i hibridni model sa rasporedom naprezanja (HSM) najpouzdanijim tročvornim elementima za analizu tankih ploča. DKT sadrži devet stupnjeva slobode, progib i dvije rotacije za tri pripadajuća čvora, kao što je prikazano na crtežu 2.5(a). Posmična deformacijska energija je u potpunosti zanemarena, ali u formulaciji se najprije pretpostavi da su posmične deformacije prisutne i deformacijska energija izražena u smislu normalnih rotacija. Zbog prisutnosti samo prvih derivacija normalnih rotacija u izrazu za deformacijsku energiju, funkcije oblika korištene pri opisivanju normalnih rotacija zadovoljavaju samo $C^{0}$ kontinuitet. Normalne rotacije su najprije izražene u smislu čvornih vrijednosti na krajevima i sredinama stranica koristeći standardne kvadratne oblikovne funkcije, a dalje eliminirane primjenom diskretnih Kirchhoffovih ograničenja. Iako je nekonformni element, DKT prolazi patch test i shodno tome konvergira točnom rješenju. 


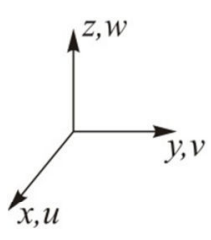

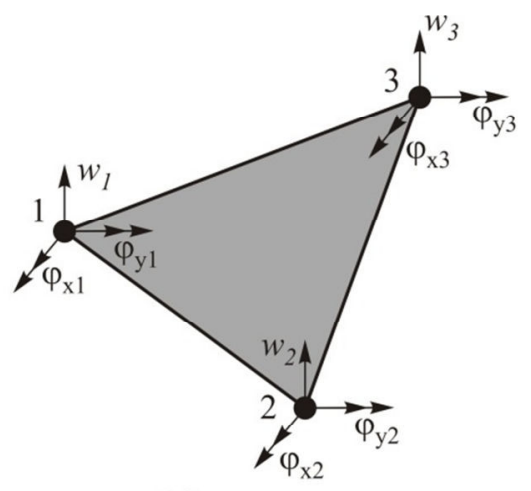

(a)

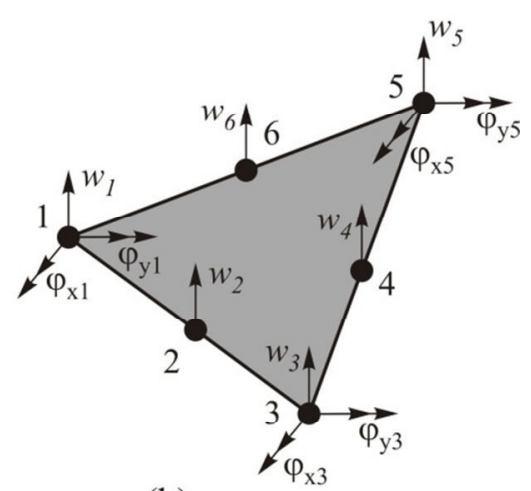

(b)

Crtež 2.5 (a) DKT konačni element (b) DKTP konačni element

Meek i Tan [M4] su razvili DKT sa tzv. Loof čvorovima. Poprečni pomak izrazili su standardnim kvadratnim funkcijama, dok su rotacije interpolirane preko vrijednosti u tzv. Loof čvorovima. Dhatt i dr. [D3] predstavili su šest čvorni diskretni Kirchhoffov element (DKTP), nastao dodavanjem stupnja slobode pomaka u polovicama stranica konačnog elementa, kao što je prikazano na crtežu 2.5(b). Unatoč povećanju stupnjeva slobode sa 9 na 12, za DKTP je pokazano isti red točnosti kao i DKT. Zbog svoje jednostavnosti DKT se puno više proširio u upotrebi i od HSM. Tessler i Hughes [T6] predstavili su tročvorni nekonformni posmično deformabilan element MIN3, temeljen na Reissner-Mindlin teoriji. Glavna pretpostavka MIN3 elementa je da rotacije variraju linearno po elementu, dok su poprečni pomaci izraženi su u kvadratnom obliku. Poprečni pomaci na sredinama stranica eliminirani su preko ograničenja da je posmična deformacija konstantna uzduž rubova elementa (crtež 2.6). Upotrebom anisoparametrijske formulacije i faktora korekcije posmika MIN3 postiže brzu konvergenciju ka točnom rješenju i prikladan je za proračun tankih i debelih ploča.
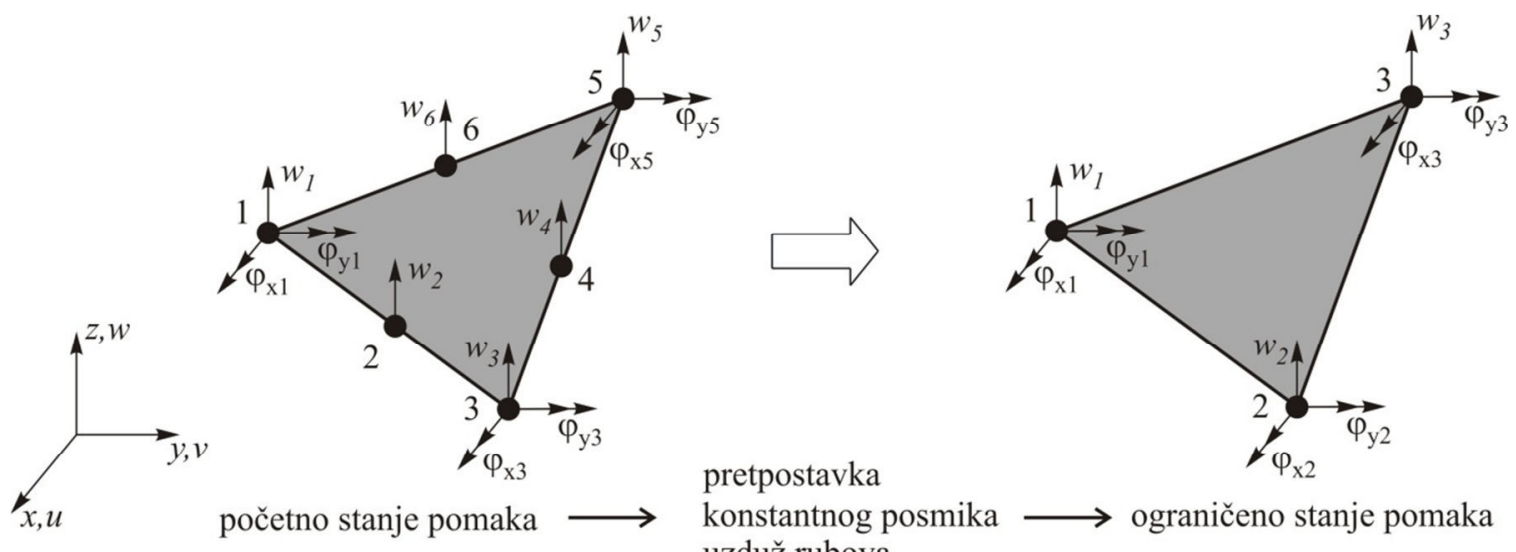

pretpostavka

konstantnog posmika $\longrightarrow$ ograničeno stanje pomaka uzduž rubova

Crtež 2.6 MIN3 konačni element

Felippa i Bergan [F4] predstavili su trokutasti element za analizu ploča temeljen na slobodnoj formulaciji. Element je nastao modifikacijom kubičnih izraza iz [B8]. Budući da je 
slobodna formulacija temeljena na principima patch testa, element nastao upotrebom ovog principa sa sigurnošću zadovoljava patch test. Specht [S12] je također predstavio modificiranu verziju od [B8], nastalu nametanjem uvjeta da su integrirani skokovi pomaka i njihove derivacije uzduž stranica elementa jednake nuli. Sze i dr. [S17], [S18] su formulacijom pretpostavljenih deformacija razvili šest čvorni trokutasti $C^{0}$ element. Element uzima u obzir poprečna posmična naprezanja, ne pati od posmičnog blokiranja i prolazi patch test. Piltner i Taylor [P11] razmatrali su tri seta poboljšanih funkcija deformacija s ciljem poboljšanja tročvornih trokutastih elemenata sa tri rotacijska stupnja slobode. Bletzinger i dr. [B13] predstavili su tzv. Discrete Shear Gap metodu za analizu Reissner-Mindln ploča. Rezultat je element oslobođen od problema posmičnog blokiranja.

U novije vrijeme četverostranični elementi su se pokazali nadmoćnijima pri analizi ploča u odnosu na trokutaste elemente. Trokutasti elementi korisniji su pri opisivanju dvostruko zakrivljenih geometrija, pa se njihov razvoj više usmjerio na analizu konstrukcija ljusaka. Bezine [B12] je prikazao usporedbe različitih elemenata za analizu ploča u inženjerskim software-ima temeljenim metodi konačnih elemenata, za tanke i debele ploče. Također, novija istraživanja sve više uključuju hibridne i mješovite formulacije (sa svrhom otklonjenja problema posmičnog blokiranja) i fokusiraju se na analize debelih ploča.

Maunder i dr. [M2] razvili su hibridni element s raspodjelom naprezanja kod kojeg su bočna polja pomaka korištena u dobivanju ravnotežnih modela, sa ravnotežom u jakoj formulaciji. Brasile [B14] je razvio mješoviti hibridni trokutasti element prema Reissner-Mindlin teoriji TIP3, koristeći metodu vezane interpolacije [T5]. Budući da vezana interpolacija ne može osigurati element oslobođen posmičnog blokiranja primijenjena je i reducirana integracija. Razvijeni element uspio je zadovoljiti patch test čak i za jako tanke ploče. Hibridni Trefftz konačni elementi su se također pokazali vrlo učinkovitima pri modeliranju ploča. Trokutasti elementi nastali na tom principu mogu se pronaći u radovima poput Choo i dr. [C9] i Rezaiee-Pajand i Karkon [R6]. Oba istraživanja pokazala su visoku točnost razvijenih elemenata pri analizi ploča, uz odsustvo problema posmičnog blokiranja.

Kod primjene mješovitih formulacija, najzastupljenija je MITC metoda koju predlažu Lee i Bathe [L4], [L6]. Osnovna ideja MITC tehnike je odvojena interpolacija pomaka i deformacija, te zatim njihovo povezivanje u tzv. čvornim točkama. Interpolacije pomaka i deformacija odabrane su na takav način da se spriječe tzv. spurious zero energy modovi i postigne konvergencija ka točnom rješenju neovisno o debljini ploče. Unatoč poboljšanjima ove formulacije, element nije oslobođen problema posmičnog blokiranja. 
Serpik [S6] je razvio tročvorni element za analizu tankih ploča nastao prema načelima patch testa. Cai i dr. [C1] predstavili su jednostavni trokutasti element DST-S6 nastao kombinacijom DKT, dodajući dva dodatna stupnja slobode u svaki čvor. Dodatni stupnjevi slobode predstavljaju rotacije koje uzrokuju poprečne posmične deformacije $\gamma_{x}$ i $\gamma_{y}$, kako je pokazano za $\gamma_{x}$ na crtežu 2.7 .

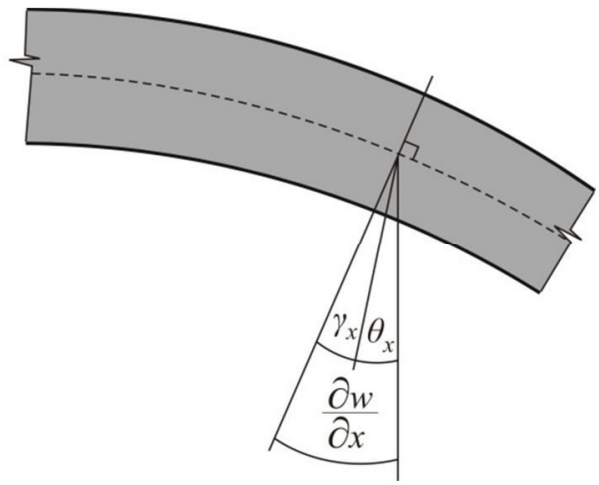

Crtež 2.7 Rotacija uslijed poprečne posmične deformacije [C1]

Kod slučaja tankih ploča DST-S6 konvergira ka DKT. Numerički primjeri pokazali su da je ovim pristupom izbjegnut problem posmičnog blokiranja, da element prolazi patch test te ima visoku točnost i brzu konvergenciju. Prikladan je za tanke i debele ploče. Element sa dva dodatna posmična stupnja slobode obrađen je i od Zhuang i dr. [Z5]. Detaljni prikaz elemenata korištenih za analizu ploča prema Reissner-Mindln teoriji dat je u preglednom članku [C3].

(c) Modeliranje ljusaka trokutastim konačnim elementima

Modeliranje ljuske ravnim trokutastim elementima uključuje spoj membranskih (CST, LST, Allmanov element) i savojnih deformacija (DKT, MIN3 i Morleyov element), kao što je prikazano na crtežu 2.8 .

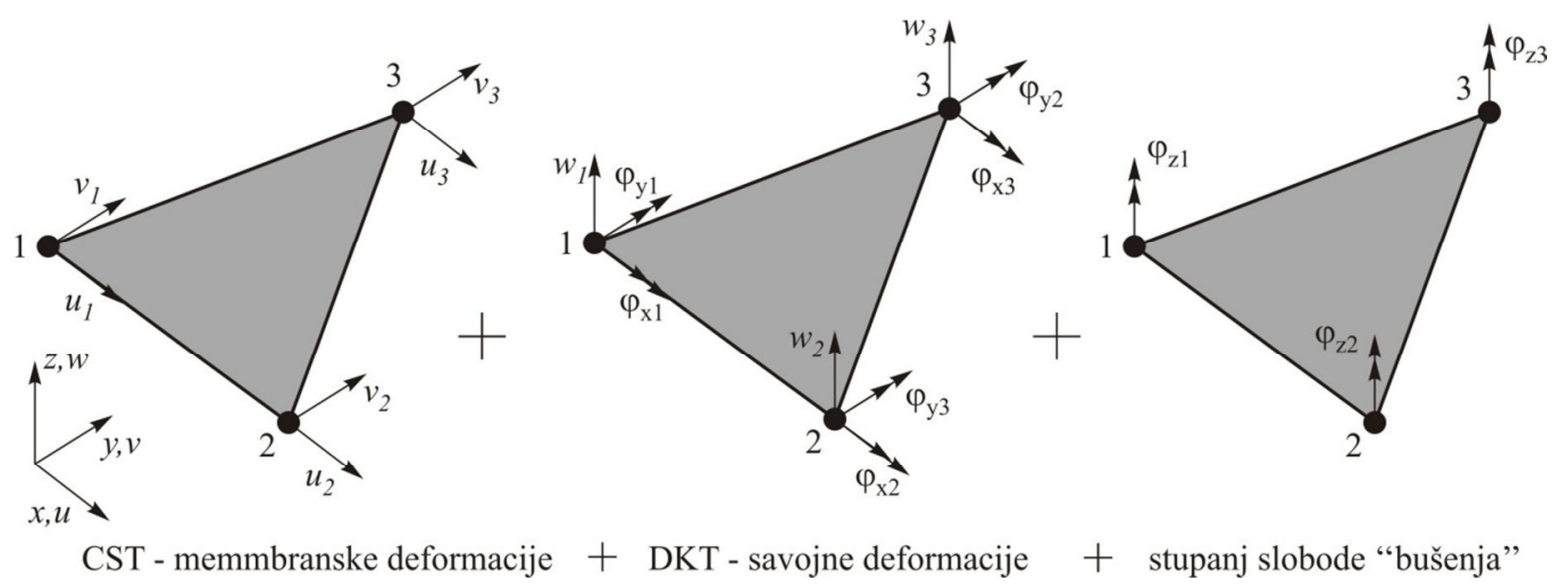

Crtež 2.8 Nastanak tročvornog konačnog elementa za analizu ljusaka pomoću DKT elementa 
Nedostatci koji su se pojavili uz takav pristup razvili su ravne trokutaste elemente temeljene na mješovitim i hibridnim formulacijama. Većina njih je primarno namijenjena za nelinearnu analizu ljusaka, budući da je nelinearna analiza sa ravnim elementima ekonomičnija od one sa zakrivljenim elementima. Nelinearnost se obično ostvaruje obnovljenom Lagrangeovom formulacijom (eng. updated Lagrangian formulation) gdje se varijable nalaze u referentnom sustavu koji se u svakom vremenskom koraku ažurira tj. obnavlja.

Ravne trokutaste elemente za nelinearnu elastičnu analizu ljusaka uveo je Argyris [A6]. Njegova formulacija temeljena je na odvajanju pomaka krutog tijela od deformacija elementa. Horrigmoe i Bergan [H4] predstavili su trokutasti hibridni element ljuske s raspodjelom naprezanja za nelinearnu analizu. Chen [C6] je predstavio trokutasti element nastao kombinacijom CST i Morleyovog trokuta za elastoplastičnu analizu ploča i ljusaka. Chen je koristio Von Karman-ovu teoriju velikih pomaka uz Lagrangeovu formulaciju za opisivanje deformacije elementa, ali su njegovi primjeri uključivali samo male rotacije. Peric i Owen [P8] predstavili su formulaciju za tanke ljuske identičnu onoj od Chena, ali uz primjere koji uključuju velike rotacije. Bathe i Ho [B4] razvili su trokutasti element kombinirajući DKT i CST element. Za velike pomake primijenjena je obnovljena Lagrangeova formulacija. Membranska naprezanja i unutarnje sile računati su prema [H4] dok su zakrivljenosti i savojni momenti računati iz inkrementalnih pomaka i ažurirani na kraju svakog inkrementa. Zbog upotrebe linearne inkrementalne formulacije bez otklanjanja rotacija krutog tijela iz ukupnih inkrementalnih pomaka, formulacija je ograničena na male inkrementalne rotacije. Hsiao [H5] je uspio riješiti ta ograničenja uklanjajući modove krutog tijela u dvije faze. U prvoj fazi nedeformirani element je rotiran do međupozicije koristeći rotaciju izvan njegove ravnine, dok se dalje postavlja u konačni položaj koristeći rotaciju u ravnini elementa. Peng i Cristfield [P7] predstavili su konačni element identičan kao kod Chena, ali su primjenom sličnog postupka kao i Hsiao odvojili pomake krutog tijela od ukupnih pomaka i time omogućili primjenu i kod velikih prirasta opterećenja. Mek i Tan [M5] predstavili su trokutasti element nastao kombinacijom LST i diskretnog Kirchhoffovog elementa sa tzv. loof čvorovima. Mana tog elementa je što zbog prisutnosti članova četvrtog reda u formulaciji treba uzeti sedam točaka za numeričku integraciju matrice krutosti. Poulsen i Damkilde [P12] su predstavili trokutasti element nastao kombinacijom LST i savojnog elementa poput onoga od [M5], sa očuvanjem simetričnosti i poboljšanjem funkcije poprečnih pomaka u svrhu bolje raspodjele opterećenja i boljih rezultata u nelinearnoj analizi. Međutim, ni Mek i Tan [M5] ni Poulsen i Damkilde [P12] nisu prikazali primjere koju uključuju velike rotacije. Fafard i dr. [F1] predstavili su šestčvorni ravni trokutasti element DLTP nastao kombinacijom šestčvornog Kirchhoffovog 
elementa DKTP [D3] i LST, uz primjenu dviju Lagrangeovih formulacija. Prva formulacija ULF1 predstavlja potpunu Lagrangeovu formulaciju na svakom koraku, s time da je konfiguracija na početku vremenskog koraka pretpostavljena kao referentna konfiguracija. Proračun naprezanja i tangentne matrice krutosti uzima u obzir sve nelinearnosti. Druga formulacija ULF2 je puna obnovljena Lagrangeova formulacija gdje je konfiguracija predložena na kraju svake iteracije uzeta kao referentna konfiguracija. Iako se koristi linearizirana inkrementalna formulacija naprezanja su izračunata pomoću nelinearne veze pomaka i deformacije.

Madenci i Braut [M1] predstavili su ravni element za statičku analizu kompozitnih ljusaka nastao kombinacijom membranskih i savojnih elemenata razvijenih od Bergana i Fellipe [B10] i [F4]. Madenci i Braut koristili su obnovljenu Lagrangeovu formulaciju u kojoj su modovi krutog tijela otklonjeni koristeći proceduru od Hsiaoa [H5]. Prisustvo stupnja slobode bušenja uspješno je eliminiralo problem singularnosti. Oral i Barut [O8] predstavili su posmično deformabilan ravni element za velike pomake ljusaka nastao kombinacijom Allmanovog trokuta i MIN3 savojnog elementa. Također su koristili obnovljenu Lagrangeovu formulaciju u kojoj su modovi krutog tijela otklonjeni koristeći proceduru od Hsiao-a [H5].

U svim do sada navedenim elementima, osim Bathe i Ho [B4], Fafrad i dr. [F1], Meek i Tan [M5] i Poulsen i Damkilde [P12] velikim rotacijama pristupljeno je na način da su modovi krutog tijela otklonjeni iz ukupnih inkrementalnih pomaka. Predstavljeno je i nekoliko formulacija za velike rotacije temeljene na izoparametrijskim elementima i totalnoj Lagrangeovoj formulaciji uz korištenje rotacijskih matrica sa tri rotacijske komponente [S8], [P3], [I2] ili korištenjem nelinearnih trigonometrijskih funkcija parametriziranih sa dvije rotacijske komponente [S16]. Onate i dr. [O5] predstavili su trokutasti element za geometrijski nelinearnu analizu, nastao kombiniranjem LST elementa i savojnog elementa temeljenog na Reissner-Mindlin teoriji, sa linearnom interpolacijom poprečnih pomaka koristeći krajnje čvorove i linearnom interpolacijom okomite rotacije i poprečnih deformacija koristeći čvorove na polovicama stranica. Ova formulacija prikladna je za tanke i debele ljuske.

Kontinuirani interes za razvoj preciznijih i računalno efikasnijih trokutastih elemenata odlikovao se stalnim razvojem novih trokutastih elemenata [L12], [A7]. Značajan broj radova objavljen je na temu mješovitih formulacija i MITC trokutastog tročvornog i šestčvornog konačnog elemenata [L5], [L6]. MITC, tzv. mixed interpolation of tensorial components, interpolira pomake i deformacije odvojeno, te ih veže u definiranim točkama na konačnom elementu. Poprečni posmik pretpostavljen je konstantnim uzduž rubova elementa, kao što je prikazano na crtežu 2.9 . 

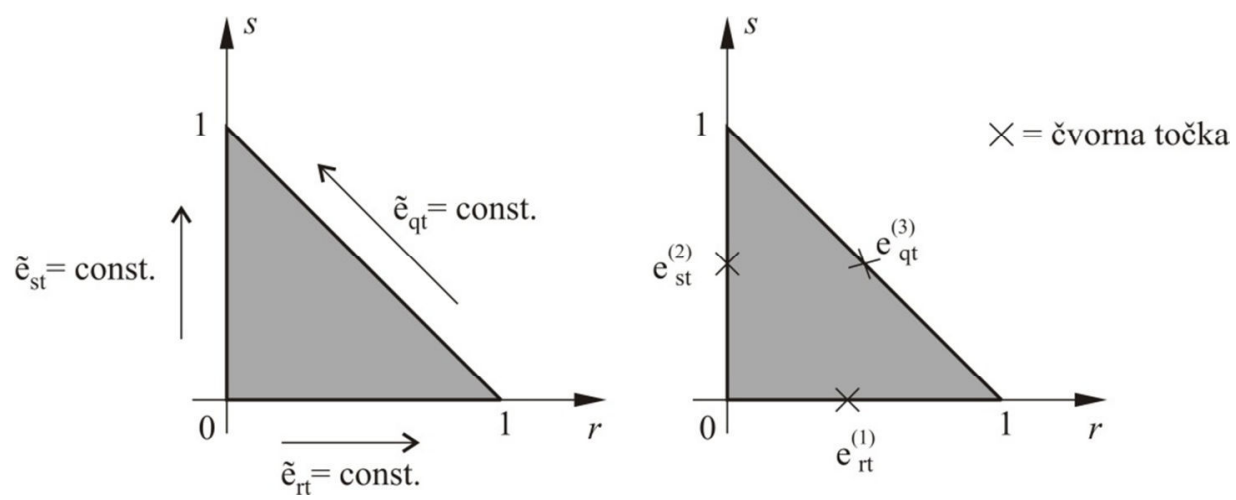

Crtež 2.9 Polje poprečnih posmičnih deformacija i pripadne povezujuće točke za tročvorni MITC konačni element [L6]

Iako su učinkovitiji od klasičnih elemenata na bazi pomaka i pristupa sa selektivnom reduciranom integracijom, još uvijek su patili od posmičnog blokiranja zbog čega su razvijena i poboljšanja u tročvornom MITC3 [L9] i šestčvornom MITC6 [K3] elementu. Autori su također razvili MITC3+ element [L8] obogaćen tzv. bubble kubičnim funkcijama za rotaciju i pretpostavljenim poprečnim posmičnim deformacijama. Ovaj element bilježi izvrsnu konvergenciju te se u kombinaciji sa potpunom Lagrangeovom formulacijom [J2] pokazao učinkovitim i u nelinearnoj analizi ljusaka. Shin i Lee [S7] razvili su tročvorni trokutasti element sa 18 stupnjeva slobode i ANDES formulacijom za membransku komponentu elementa. Također su primijenili tehniku izglađivanja deformacija i uveli faktor modifikacije, kako bi se poboljšalo ponašanje elementa.

U svrhu još jednostavnije analize ljuska razvijeni su trokutasti konačni elementi bez rotacija (RF), primjenjivi isključivo za analizu tankih ljusaka. RF elementi koriste grupu od četiri konačna elementa, kao što je prikazano na crtežu 2.10, da bi se iz njihovih pomaka odredila zakrivljenost središnjeg konačnog elementa. Kod analize ploča potrebno je poznavati samo vertikalni pomak, dok je kod analize ljusaka potrebno poznavati sva tri pomaka u čvorovima grupe elemenata.

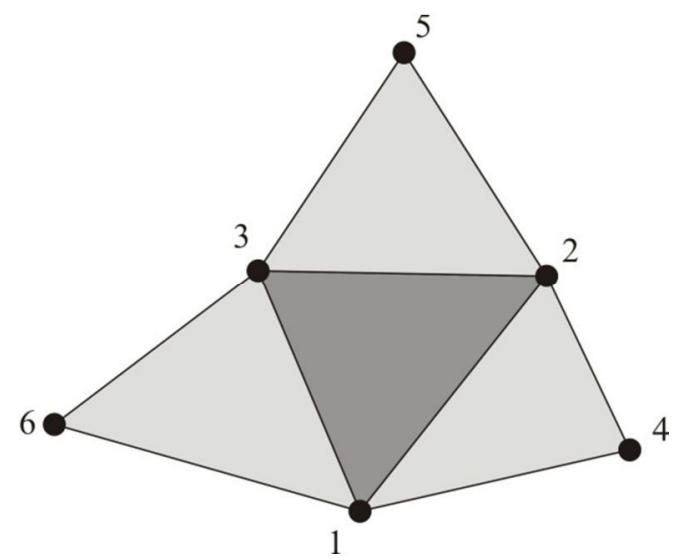

Crtež 2.10 Grupa konačnih elemenata sa kontrolnim elementom u sredini 
Barnes [B3] je prvi predstavio teoriju o RF elementima, gdje se na temelju rotacija grupe elemenata (Crtež 2.10) određuje konstantna zakrivljenost okomita na rubove središnjeg konačnog elementa. Superpozcijom zakrivljenosti rubova dalje se formira matrica krutosti konačnog elementa. Bernes nije predstavio numeričke rezultate ove ideje. Chan i Davies [C4] određivali su kutove rotacije elementa koristeći poprečne pomake, ali uz korištenje pretpostavljenih zrcalnih elemenata na rubovima. Kasnije su Hampshire i dr. [H1] proširili ideju od Chena i Davisa, zamjenjujući pretpostavljene zrcalne elemente sa susjednima. Phaal i Calladine [P9] su pomoću kvadratnog polinoma određivali konstantnu zakrivljenost nad grupom konačnih elemenata, te kombinacijom sa CST elementom omogućili analizu ljusaka. Iako se ovaj element u početku pokazao nepraktičnim, kasnije je pokazano da postiže dosta dobre rezultate kod nestrukturiranih mreža [G1]. Oñate i Cervera [O3] predstavili su savojni element sa neovisnom aproksimacijom zakrivljenosti, izraženim preko gradijenta progiba uzduž rubova konačnog elementa. Njegovom kombinacijom sa CST elementom Oñate i Zarate [O7] su predstavili formulaciju za analizu ljusaka, kasnije proširenu na velike progibe [O4] te uvrnute i razgranate ljuske [F9]. Kasnije je također kombiniran sa LST elementom [F8] da bi se postiglo bolje opisivanje membranskih naprezanja. Sabourin i Brunet [S1] su razvili RF trokutasti element koristeći matricu krutosti predloženu od Barnesa [B3], vezu kutova rotacije i pomaka preuzetu od Chan i Davies [C4], te rubne uvjete poput onih od Oñate i Cervera [O3]. Guo i dr. [G4] razvili su RF element koristeći DKT6 savojni element prema [R7] u kombinaciji sa CST. U grupu drugačijih RF elemenata spada Laurent i Rio [L1], gdje su se korištenjem isoparametrijskih interpolacija modelirale normalne zakrivljenosti uzduž ruba elementa, što je dovelo do problema pronalaženja integracijskih točaka. Potrebno je spomenuti elemente od Hauptmann i Schweizerhof [H2] gdje je razvijen RF element koji koristi pomake na dnu i vrhu poprečnog presjeka, te Dung i Wells [D10] gdje je predstavljen RF element temeljen na standardnim Lagrangeovim funkcijama pomaka. Također, nedavno su Zhou i Sze [Z3] predstavili RF element nastao produženjem [P9] formulacije. Produženje se odnosi na zakrivljene geometrije, kod kojih se pristup zglobova na elementima zamjenjuje jednostavnim principom interpolacije. Ovaj model pokazao se učinkovitim kod geometrijski vrlo nelinearnih analiza (npr. simulacija ovjesa).

\subsubsection{Problematična ponašanja pri numeričkoj analizi lukova i ljusaka}

Primjenom MKE za analizu lukova i ljusaka uočeno je kako konačni elementi temeljeni na metodi pomaka mogu davati loše rezultate i bilježiti slabu konvergenciju. Dobiveni pomaci konstrukcije iznosima su bili premali u odnosu na stvarno fizikalno ponašanje. Shodno tome 
razvio se pojam blokiranja, kao opis lažnog povećanja krutosti, opisujući time to što se konstrukcija blokira prema pomacima. Prema mehanizmu nastanka blokiranje se dijeli na posmično, membransko, i volumensko.

(a) Posmično blokiranje (eng. shear locking)

Posmična krutost počinje dominirati rješenjem, čineći promatrane elemente nerealno krutima Posmično blokiranje se, prema mehanizmu nastanka, dijeli na posmično blokiranje u ravnini i na poprečno posmično blokiranje.

Posmično blokiranje u ravnini pogađa 2 d i $3 d$ elemente. Efekt se može ilustrirati kada se deformacije uslijed čistog savijanja opisuju konačnim elementima sa linearnim funkcijama oblika, kao što je prikazano na crtežu 2.11. U slučaju četveročvornog elementa normalna naprezanja $\sigma_{x}$ variraju linearno i odgovaraju ideji savijanja dok istovremeno postoje i posmična naprezanja $\tau_{x y}$ koja variraju linearno sa $x$ koordinatom [K8]. Budući da posmična naprezanja ne odgovaraju problemu čistog savijanja, a javljaju se skupa sa normalnim naprezanjima, smatramo ih parazitskim. Posmične deformacije dalje preuzimaju dio deformacijske energije i ukrućuju promatrani problem. Potrebno je naglasiti kako s matematičkog stajališta ovaj problem ne postoji, odnosno nije uzrokovan pogreškom u proračunu već samim oblikom konačnog elementa.
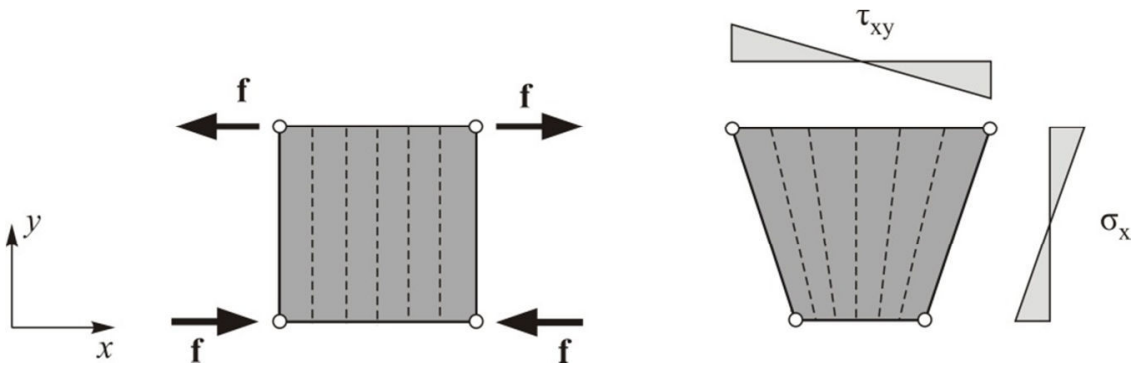

Crtež 2.11 Posmično blokiranje u ravnini

Efekt poprečnog posmičnog blokiranja javlja se kod elemenata baziranih na ReissnerMindlin teoriji, odnosno kod uzimanja u obzir poprečnog posmičnog deformiranja konstrukcije. Blokiranje nastaje uslijed nedostatka koordinacije u opisivanju pomaka i posmičnog zaokreta, odnosno pretpostavke o njihovoj neovisnosti. Uzimanjem istih interpolacijskih funkcija za opisivanje pomaka i zaokreta stvaraju se parazitska poprečna posmična naprezanja koja se povećavaju sa smanjenjem odnosa visine presjeka i duljine konstrukcije, što je suprotno stvarnom fizikalnom ponašanju. Posmična energija tada počinje dominirati ukupnom deformacijskom energijom rezultirajući nerealno krutim ponašanjem. Budući da je ovaj efekt najistraženiji vid blokiranja, mehanizam njegovog nastanka detaljno je prikazan u brojnoj literaturi [D9], [B5], [C15], [B17]. 
(b) Membransko blokiranje

Do membranskog blokiranja dolazi isključivo kod zakrivljenih elemenata (lukova i ljusaka). U slučaju njihovog opterećenja čistim momentnom savijanja u rješenju se, uslijed približnog opisivanja pomaka funkcijama nižeg reda, pojavljuju parazitska membranska naprezanja koja nerealno ukrućuju promatrani element [C15], [B5]. Drugim riječima, konačni elementi nisu u mogućnosti savojne deformacije opisati nerastezljivim ponašanjem. Shodno tome, ovaj efekt izražen je kod vitkih elemenata pod dominantno savojnim opterećenjem. Potrebno je napomenuti kako do njega dolazi ako su i elementi kojima se opisuje geometrija zakrivljeni. Linearni trokuti su uvijek ravni, pa su stoga u potpunosti oslobođeni od ovog efekta, neovisno o obliku ljuske koju opisuju. Ovaj efekt izražen je kod kvadratnih i bikvadratnih elemenata.

(c) Volumensko blokiranje

Za razliku od ostalih blokiranja, volumensko blokiranje ovisi o parametru materijala tj. Poissonovu koeficijentu [C15]. Element nije u stanju modelirati određene deformacije bez promjene $\mathrm{u}$ volumenu. Kod nestišljivih materijala, odnosno kako Poissonov koeficijent $v \rightarrow 0.5$ modul posmika $\mathrm{G} \rightarrow \infty$, što znači da svaki mali dio elementa mora sačuvati svoj volumen pri bilo kojoj deformaciji. Kao posljedica dolazi do nestišljivog ponašanja materijala i nerealno visoke krutosti. Kada je Poissonov koeficijent jednak nuli ne dolazi do problema volumenskog blokiranja. Mehanički gledano, parazitska naprezanja koja dovode do ovog efekta su normalna naprezanja.

Sprječavanje efekta blokiranja konstrukcije

Problem blokiranja uočen je na konačnim elementima temeljenima na metodi pomaka, koji se izvode iz varijacijskog principa minimuma potencijalne energije ili principa virtualnih pomaka [S11]. Neovisne varijable su pomaci, derivacijom kojih se izvode ostale veličine potrebne za procjenu stanja derivacija i naprezanja. Pritom se pogreška nastala pri pomaku znatno uvećava, a pojavljuju se i poteškoće pri zadovoljavanju potrebnih uvjeta kompatibilnosti što je posebno izraženo u analizi ploča i ljusaka. Budući da je problem blokiranja poznat od samih početaka MKE razvijeni su brojni načini za njegovo prevladavanje, a najrašireniji uključuju:

- korištenje elemenata višeg reda,

- reducirana integracija i selektivna reducirana integracija,

- mješovite i hibridne formulacije konačnih elemenata,

- metoda pretpostavljene deformacije (ANS), 
- metoda poboljšanje deformacije (EAS),

- metoda raskoraka u posmiku (DSG).

Iako korištenje elemenata višeg reda znatno umanjuje probleme blokiranja, konačni elementi nižeg reda se zbog svoje računalne jednostavnosti smatraju iznimno atraktivnima. Prvi i najjednostavniji pokušaj eliminiranja blokiranja bila je reducirana integracija [Z6], [B5]. Iako u nekim slučajevima može davati točna rješenja, vodi do tzv. spurious zero energy modes. Selektivna reducirana integracija uvela je različite redove integracije za različite deformacije [B5]. Tu se pojavio isti problem kao i kod reducirane integracija, ali u manjoj mjeri, zbog čega je selektivna reducirana integracija pronašla širu primjenu [B17], [A8].

Mješovita formulacija izvedena je iz proširenih varijacijskih principa. kao što su $\mathrm{Hu}-$ Washizuov i Hellinger-Reissnerov varijacijski princip [S11]. Temelji se na uvođenju novih neovisnih varijabli koje, osim pomaka, mogu biti deformacija i naprezanje, odnosno unutarnje sile i momenti. Neovisne varijable opisuju se interpolacijskim funkcijama na cijelom području elementa, a prikladnim izborom tih varijabli može se izbjeći pojava blokiranja. Sukladno tome, broj nepoznatih veličina u čvorovima je povećan, pa je matrica konačnog elementa složenija je nego kod metode pomaka. Hibridna metoda postoji kao hibridna metoda pomaka i mješovita hibridna metoda izvedene iz principa minimuma potencijalne energije, te kao hibridna metoda sila izvedena iz principa minimuma komplementarne potencijalne energije. Hibridna metoda pomaka pokazuje polje pomaka unutar elementa kao funkciju poopćenih parametara pretpostavljene interpolacijske funkcije, dok se duž rubova zadaje raspodjela naprezanja ovisno o njihovim čvornim veličinama. Mješovita hibridna metoda opisuje pomake unutar elementa i naprezanja duž rubova pomoću poopćenih parametara, a raspodjela pomaka duž rubova opisuje se kao funkcija pomaka u čvorovima. Hibridna metoda sila opisuje raspodjelu naprezanja unutar elementa, dok se raspodjela pomaka duž rubova opisuje interpolacijskim funkcijama ovisno o čvornim pomacima. Detaljnije o ovim metodama može se pronaći u [S11], [B5], [Z7].

Metodu pretpostavljenih deformacija ANS predstavili su Park i Stanley [P4]. Ideja ove metode je zamjena polja deformacija izračunatih iz pomaka, unutar principa minimuma potencijalne energije, sa nezavisno pretpostavljenim deformacijama u odgovarajućim točkama elementa. U općem slučaju ANS metode određuju se: - komponente deformacija koje će biti zamijenjene, - pozicija odgovarajućih točaka, - usvojene interpolacije za pretpostavljene deformacije. Iako elementi nastali iz ovog pristupa, poput MITC elemenata, postižu dobre rezultate nema strogo određenog kriterija za pretpostavljene deformacija. Felippa i Militello [F6] 
su kombinacijom slobodne formulacije i ANS metodu pretpostavljenih devijatorskih naprezanja ANDES.

Metodu poboljšanje deformacije EAS predstavili su Simo i Rifai [S9]. Metoda se temelji na Hu-Washizu varijacijskom principu u kojem se pomaci, deformacije i naprezanja tretiraju kao nepoznate veličine. Iz ovog se pristupa razvila cijela klasa konačnih elemenata koji su, za razliku od elemenata temeljenih na metodi pomaka, oslobođeni problema posmičnog i volumetrijskog blokiranja. Bletzinger i dr. predstavili su metodu raskoraka u posmiku [B13] koja se temelji na dekompoziciji savojnih i posmičnih deformacija. DSG uspoređuje stvarne pomake sa onima od čistog savijanja, i njihovu razliku naziva posmičnim raskorakom. Posmične deformacije dalje se određuju iz posmičnog raskoraka i eliminiraju parazitska posmična naprezanja. Autori su pokazali kako ova metoda uspješno otklanja posmično blokiranje uz visoku računalnu učinkovitost.

\subsection{MODELIRANJE LUKOVA I LJUSAKA POMOĆU BEZMREŽNIH METODA I METODE RUBNIH ELEMENATA}

Iako je metoda konačnih elemenata naširoko prihvaćen numerički alat za analizu lukova, ploča i ljusaka, ona u sebi sadrži i ograničenja nametnuta samom mrežom konačnih elemenata. Kreiranje mreže pokazalo se manjkavim za slučajeve velikih deformacija, pojavu pukotina ili značajnijih distorzija mreže. Također, samo formiranje mreže konačnih elemenata zahtjeva računalni angažman, kojeg nam je u interesu minimizirati. U potrazi za prilagodljivijim i robusnijim pristupom u zadnja je dva desetljeća došlo je do razvoja tzv. bezmrežnih metoda, koje osiguravaju riješenje preko skupa slučajno raspodjeljenih čvorova bez predefinirane mreže koja te čvorove povezuje [L20]. Postoji cijeli niz do sada predloženih bezmrežnih metoda s razlikama u formulacijskim procesima (jaka, kolokacijska ili slaba), aproksimacijskim funkcijama (Smoothed Particle Hydrodynamics SPH, Reproducing Kernel Particle Method RKPM, Moving Least Squares MLS, Point Interpolation Method PIM, ...) i zastupljenosti domene (cijela domena ili samo rubni dio).

Pregledom dosadašnje literature iz bezmrežinh metoda zastupljenih u analizi greda, lukova, ploča i ljusaka najzastupljenijima su se pokazale bezmrežne metode temeljene na slabim formulacijama poput lokalne Petrov-Galerkin metode (MLPG) i Element free Galerkin metode (EFG). Analizu tankih greda MLPG metodom prvi su predložili su Alturi i drugi [A10]. U predmetnom radu također su predložili i generaliziraciju konvencionalne MLS interpolacije uvođenjem nagiba kao dodatne neovisne varijable, što je primjenjivo i na drugim bezmrežnim 
metodama. Raju i dr. [R1] također su predložili analizu tankih greda sa MLPG metodom, ali uz upotrebu radijalnih baznih interpolacijskih funkcija umjesto generaliziranie MLS interpolacije. Ovaj pristup pokazao se računalno efiksanijim, postižući bolju točnost uz manje računalnih operacija. Analiza greda EFG metodom i MLS aproksimacijom predložena je od strane Tiago i Leitão [T8] u svrhu slobodnih oscilacija, te od Xia i drugih [X1] u svrhu gemotrijski nelinearne analize posebno pogodne za velike pomake. Wang i Chen [W1] su dalje proširili analizu bezmrežnih metoda na zakrivljene grede, posebno adresirajući probleme blokiranja. Predložena formulacija temelji se na Stabilized Conforming Nodal Integration (SCNI), i stanje čistog savijanja kod tankih zakrivljenih greda opisuje bez parazitskih posmičnih i mebranskih naprezanja.

Prva istraživanja Kirchhoff-ovih ploča bezmrežnim metodama uključivala su primjenu Diffuse element method [H3], i nisu polučila zadovoljavajuće rezultate. Krysl i Belytschko su kasnije ponudili značajno unaprijeđenu analizu taknih ploča i ljusaka koristeći EFG metodu [K11], [K12]. U svrhu opisivanja geometrije ljuske i numeričke integracije, domena je prekrivena tzv. pozadinskim elementima (poddomenama). Metoda je temeljena na MLS aproksimaciji, dok su rubni uvjeti provedeni preko Lagrangeovih multiplikatora. Konzistentnost je osigurana odabirom kvadratnih baza od drugog i četvrtog stupnja. Li i drugi [L13] predstavili su trodimenzionalni pristup bezmrežnoj nelinernoj analizi tankih ljusaka pod velikim deformacijama, koristeći tzv. window function based bezmrežne interpolacije sa diskusijom o otklanjanju efekta blokiranja. Liu i Chen [L19] su također upotrijebili EFG metodu u kombinaciji sa MLS aproksimacijom, ali u statičkoj i dinamičkoj analizi tankih ploča različitih oblika i rubnih uvjeta. U statičkim analizama rubni su uvjeti osigurani tzv. penalty metodom, dok su u dinamičkim analizama osigurani ortogonalno transformacijskom tehnikom. Navedeni pristup kasnije je proširen i na spregnute ploče [C7] te na tanke ljuske [L21]. Peng i drugi [P5] predložili su statičku analizu koncentrično i ekscentrično ukručenih ploča prema EFG metodi u kombnaciji sa teorijom posmične deformabilnosti prvoga reda. Ukručena ploča promatrana je kao ploča spregnute sa gredama. Autori su kasnije proširili nalaizu na orebrebrene ukrućene i neukručene ploče, promatrane kao ortotropne ploče spregnute sa gredama [L15], [P6], [L14]. Belinha i Dinis [B9] predložili su EFG metodu za nelinearnu analizu ploča i višeslojnih ploča uzimajući teoriju posmične deformabilnosti prvog reda i MLS aproksimaciju oblikovnih funkcija. U upotrebi bezmrežnih metoda kod analize graničnih stanja, Le i drugi [L2] su modelirali ploče koristeći h-adaptive EFG metodu sa MLS aproksimacijom. U predloženoj analizi čvorovi mogu biti premješteni, odbačeni ili dodatno uvedeni bez složenih manipulacija podacima. Pogreška izračunatog polja pomaka i njegovih 
derivacija procjenjivana je sa visokom točnošću, koristeći Taylorov razvoj. EFG metoda sa MLS aproksimacijom upotrebljena je i kod problema lokalnog izbočavanja čeličnih greda sa nepravilnim otvorima u pojasevima, [A1], te kod problema izbočavanja kosih i romboidnih tankih ploča [J1]. U novije vrijeme, Wang i drugi [W2], [W3] uspješno su predstavili dinamičku analizu i analizu stabilnosti tankih ploča koristeći Galerkinov bezmrežni pristup sa Hermite reproducing kernel aprokismacijom. Moosavi i drugi [M8] predložili su ortogonalnu bezmrežnu metodu konačnih volumena, te primjerima pokazali visoku učinkovitost metode pri analizi ljusaka.

Unatoč prednostima, bezmrežne metode također bilježe značajne računalne zahtjeve te povremene nestabilnosti. Alternativno dolazi do primjene metode rubnih elemenata (MRE), koju karakterizira diskretizacija samo po rubovima domene, odnosno isključivo rubno modeliranje problema [A2]. Takav pristup postignut je redukcijom problema preko domene ploče/ljuske na integralne jednadžbe po rubu elementa. Da bi se postigla potrebna redukcija, rješenje je potrebno prikazati kao sumu integrala koji odgovaraju djelujućem opterećenju i komplementarnog rješenja (neopterećeni problem sa rubnim uvjetima). MRE najčešće se djeli ovisno o pristupu pronalaska komplenetarnog rješenja na izravnu i neizravnu formulaciju. [B1], [B15]. Kao rezultat, MRE karakteritira smanjenje sustava pripadajućih jednadžbi, dok je kvaliteta rješenja ovisna isključivo o rješenju na rubu. To se prevodi u manji računalni angažman i smanjenje nepotrebnih podataka. U većini analiza MRE problem svodi na 1D linijske elemente po rubovima ploče/ljuske. Međutim, ukoliko želimo analizirati elemente nejednolike debljine, ili ih spariti sa plošnom analizom (odnos fluida i konstrukcije), korisno je primjeniti površinsku diskretizaciju i 3D teoriju elastičnosti.

Geometrijski nelinearne formulacije tankih ploča i ljusaka pomoću MRE predstavljenje su još ranih osamdesetih godina prošlog stoljeća. Prve analize tankih ploča obuhvačaju formulaciju od Kamyia i Sawaki-a [K1] temeljena na Bergerovoj jednadžbi i tehnici težinskog reziduala, te formulacija od Tanake [T1] temeljenu na Von Karmanovim nelinearnim jednadžbama. Nakon toga, MRE je u više radova uspješno primjenjena za analizu nelinearnih tankih ploča uključujući velike pomake i post-kritična ponašanja [Y2], [O1], [Q1], [A11], [T3], [T2], [W4]. MRE je također uspješno primjenjena u analizi debelih ploča [L10], [S14], uključujući velike pomake [W7], post-kritično ponašanje [W8], te kombinaciju geometrijske i materijalne nelinearnosti [S15]. Prve primjene MRE na analizu geometrijski nelinearnih ljusaka uključuju radove od Kamiya i Sawaki [K2] gdje su analizirane plitke ljuske sa proizvoljnim konturama, Tosaka i Miyake [T10] gdje je data teoretska podloga za velike progibe sa tri tipa integralnih jednadžbi, te Zhang i Atluri [Z2] gdje je obrađena analiza nakon gubitka stabilnosti plitkih ljusaka. Ye [Y1] je analizirao plitke ljuske kombiniranjem MRE i MKE, dok su Lin i Long [L16] predstavili analizu 
ljusaka sa MRE temeljenoj na metodi pomaka. Liu [L22] je analizirao 3D pristup MRE i zaključio kako kod ljusaka ne dolazi do problema degeneracije linearnog sustava jednadžbi usljed blizine dvaju površinskih granica, kao što je slučaj kod pukotina. Također je detaljno prikazan i pristup kod problema singularnosti, koji se pojavljuje kod 3D analize predmetnih konstrukcija sa MRE. Autor je također prikazao prednosti, nedostatke i primjenu predloženog modela u odnosu na MKE. Metoda dvostruke uzajamnosti, originalno predložena od Nardini i Brebbia [N1] u svrhu dinamičke analize MRE, u zadnje se vrijeme ustalila se kao način postupanja s integralima preko domene. Wen i drugi [W6] su razradili primjenu navedene metode pri transformaciji integrala domene u rubnu analizu, za slučaj posmično deformabilnih ploča i ljusaka. Dirgantara i Aliabadi [D6] su predstavili geometrijski nelinearnu analizu posmično deformabilnih ljusaka, u kojoj je rub je diskretiziran kvadratnim isoparametrijskim elementima, dok je problem domene prebačen na rubove koristeći metodu dvostruke uzajamnosti. Za rješavanje problema nelinearnosti predložili su jednostavnu i učinkovitu metodu inkrementa. U zadnje vrijeme, Useche [U2] je predstavio dinamičku analizu posmično deformabilnih elastičnih plitkih ljusaka također koristeći metodi dvostruke uzajamnosti. MRE formulacija temeljena je na izravnoj vremenskoj integraciji i elastostatic temeljnim rješenjima. Plitku ljusku modelirao je prema [W6], odnosno spajanjem MRE za posmično deformabilne ploče s membranskim stanjem naprezanja. Isti pristup kasnije je primjenjen na tranzijentnu dinamičku analizu plitkih ljusaka [U1].

\subsection{LUKOVI I LJUSKE U KOMBINIRANOJ METODI KONAČNO- DSIKRETNIH ELEMENATA}

Bangash i Munjiza [B2] predstavili su računalno učinkovit konačni element za analizu tankih grednih konstrukcija, kao što je prikazano na crtežu 2.12(a). U svrhu 3D analize, element u čvorovima posjeduje tri translacije $\mathrm{i}$ tri rotacije. Uslijed savojnih deformacija dolazi do zakrivljenost u gredi koju su autori u čvoru $i$ (crtež 2.12(b)) aproksimirali kao

$$
\kappa_{i}=\frac{2 \varphi_{i}}{h}
$$

Primjenom najjednostavnijeg (ravnog dvočvornog) konačnog elementa stvorila se podloga za daljnju učinkovitu analizu strukturalnog otkazivanja i kolapsa armirano-betonskih grednih elemenata [M13]. Razvijeni element su implementirali u kompjutorski program Yfdem. 


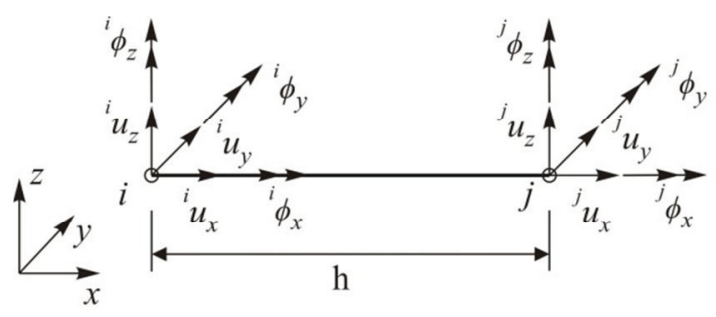

(a)

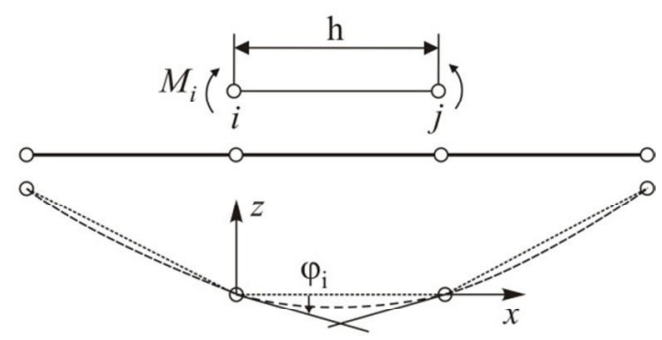

(b)

Crtež 2.12 (a) Gredni element u MKDE (b) Gredni element pod savijanjem [B2]

Paavilainen i dr. također su razvili gredni element u okviru MKDE [P1]. Njihov model pogodan je za 2D elastičnu analizu posmično deformabilnih grednih elemenata. Također su, upotrebom pristupa kohezivnih pukotina, postigli dobre rezultate pri simulaciji višestrukih pukotina $u$ grednom elementu.

Munjiza i dr. predstavili su analizu ljusaka sa razvojem konačnog elementa prikazanog na crtežu 2.13 [M16]. Razvijeni model cilja na analizu pukotina i fragmentacije kod višeslojnih konstrukcija ljuske, te je implementirali u kompjutorski program Yfdem.

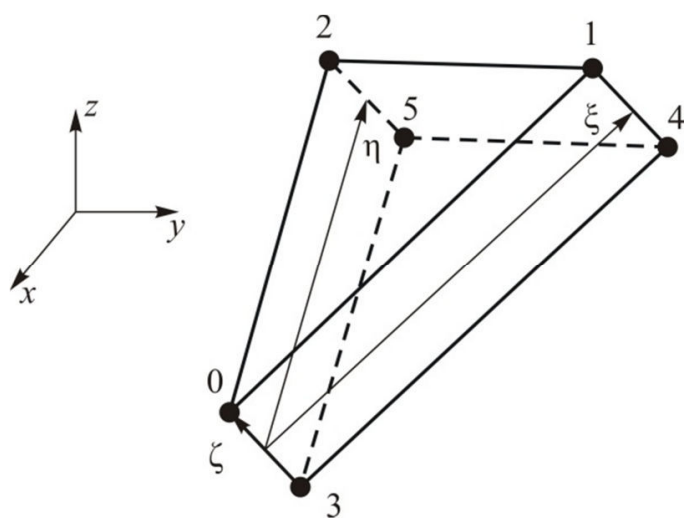

Crtež 2.13 Konačni element za analizu ljusaka sa globalnim x-y-z i lokalnim $\xi-\eta-\zeta$ koordinatnim sustavom [M16]

Kontakta interakcija riješena je upotrebom no binary search (NBS) algoritma za detekciju kontakata u kombinaciji sa opisom konačnog elementa pomoću tri tetraedra, kako je prikazano na crtežu 2.14 .

Rousseau i dr. su također modelirali ljuske u okvirima MKDE [R8]. Fokusirajući se na problem udara u armirano-betonske ljuske predstavili su spoj konačnih i diskretnih elemenata na način da se ljuska modelira konačnim elementima, dok se u blizini udara konačnim elementima pridodaju i diskretni. Lokalizacijom diskretnih elemenata samo na područje udara postiglo se znatno smanjenje obima proračuna. 

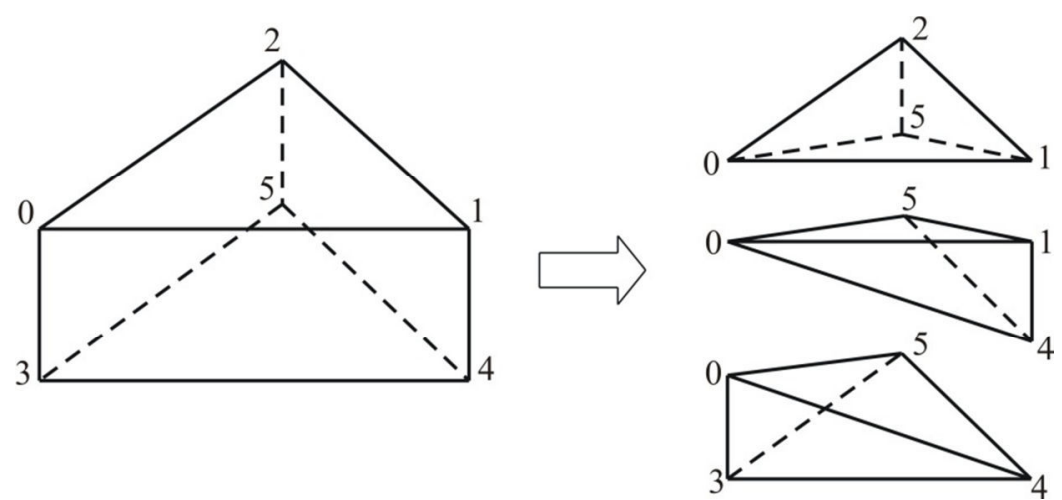

Crtež 2.14 Konačni element za analizu ljusaka podijeljen u tri tetraedra, u svrhu kontaktne interakcije [M16]

Potrebno je napomenuti kako se, u okvirima MKDE, modeliranje trokutastim tročvornim elementima do sada primjenjivalo u okvirima $2 \mathrm{D}$, dok je njihovo poopćenje u prostornu analizu prema autorovim saznanjima napravljeno jedino u vidu membranskih naprezanja [D7]. 


\section{OSNOVE KOMBINIRANE METODE KONAČNO- DISKRETNIH ELEMENATA}

U ovom poglavlju prikazat će se teoretska podloga kombinirane metode konačno-diskretnih elemenata, koja je u ovom radu korištena kao polazište za numeričku analizu zakrivljenih konstrukcija. MKDE, koju je razvio Munjiza [M12], zasniva se na simulaciji ponašanja velikog broja diskretnih elemenata koji se mogu naći u međusobnoj interakciji. Svaki diskretni element (zakrivljena konstrukcija) diskretiziran je s vlastitom mrežom konačnih elemenata, čime je omogućena njegova deformabilnost.

MKDE jednadžbe gibanja rješava eksplicitno, za svaki čvor u svakom vremenskom koraku. Jednadžbe se formiraju poznavanjem sila u čvorovima u kombinaciji sa masama koncentriranima u čvorove. Sile su proračunate obradom eventualne kontaktne interakcije diskretnih elemenata i deformacije konačnih elemenata. Shodno tome, u ovom poglavlju dat je prikaz obrade kontakte interakcije u 3D problemima, izračuna sila uslijed deformabilnosti konačnih elemenata te vremenske diskretizacije. 


\subsection{OBRADA 3D KONTAKTNE INTERAKCIJE U KOMBINIRANOJ METODI KONAČNO-DISKRETNIH ELEMENATA}

Kontaktna interakcija u kombiniranoj metodi konačno-diskretnih elemenata obuhvaća dva algoritamski odvojena aspekta:

- detekcija kontakata,

- interakcija kontakata.

Detekcijom kontakata omogućeno je prepoznavanje parova diskretnih elemenata koji su dovoljno blizu da se nalaze u mogućem kontaktu, odnosno eliminiranje onih parova diskretnih elemenata koji su dovoljno daleko da ne mogu biti u kontaktu. Na taj način daljnji proračun interakcije provodi se eliminirajući parove koji se ne nalaze u kontaktu, i time smanjuje računalni obim potreban za ukupnu analizu. U sklopu kombinirane metode konačno-diskretnih elemenata implementiran je NBS algoritam [M10] koji je prema autorovu saznanju do sada najbrži algoritam za prepoznavanje kontakata među elementima sličnih dimenzija.

Nakon detekcije elemenata slijedi proračun kontaktnih sila koje se javljaju uslijed njihove interakcije. Kontaktne sile nastaju kao rezultat pritiska između dva diskretna elementa, od kojih se jedan proglašava kontaktorom, a drugi metom [M11]. U sklopu ove metode usvojen pristup određivanja kontaktnih sila pomoću penalty koeficijenta u kombinaciji sa njihovom koncentriranom raspodjelom po dodirnoj površini, kao što je prikazano na crtežu 3.1.

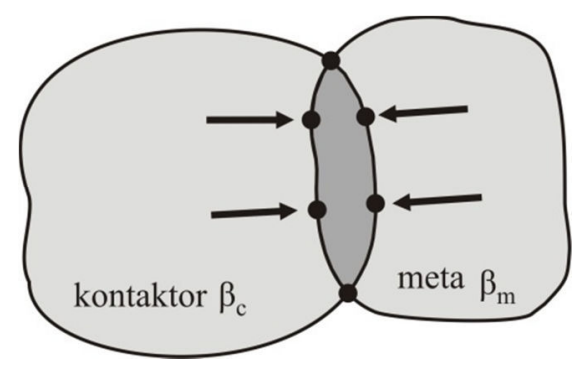

Crtež 3.1 Pristup koncentrirane raspodjele kontaktnih sila

Za potrebe proračuna kontaktnih sila nad kontaktorom i nad metom uspostavljena su potencijalna polja $\varphi_{k}$ i $\varphi_{m}$ čiji potencijal opada od središta tih elemenata prema rubovima. Penetracijom diferencijalno malog volumena $d V$ kontaktora u metu dolazi do diferencijalne sile kojom meta, uslijed svog potencijala, djeluje kontaktor

$$
d \mathbf{f}=-\operatorname{grad} \varphi_{t}\left(P_{t}\right) d V
$$


gdje je $\mathrm{P}_{\mathrm{t}}$ točka preklapanja na koja pripada meti. $\mathrm{S}$ druge strane, sila kojom meta svojim potencijalom, zbog prodora kontaktora $\mathrm{u}$ metu, djeluje na diferencijalno mali volumen $d V \mathrm{u}$ okolini točke $\mathrm{P}_{\mathrm{m}}$ koja se nalazi na meti jednaka je

$$
d \mathbf{f}=\operatorname{grad} \varphi_{c}\left(P_{c}\right) d V
$$

Ukupna kontaktna diferencijalna sila na točku može se napisati u obliku

$$
d \mathbf{f}=\left[\operatorname{grad} \varphi_{c}\left(P_{c}\right)-\operatorname{grad} \varphi_{t}\left(P_{t}\right)\right] d V
$$

Da bi se dobila ukupna kontaktna sila na kontaktor, potrebno je provesti integraciju prethodnog izraza preko cijelog preklapajućeg volumena $V$ iz čega slijedi izraz

$$
\mathbf{f}=\int_{V=\beta_{t} \cap \beta_{c}}\left[\operatorname{grad} \varphi_{c}-\operatorname{grad} \varphi_{t}\right] d V
$$

koji se još može zapisati u obliku

$$
\mathbf{f}=\int_{S \beta_{t} \cap \beta_{c}} \mathbf{n}\left(\varphi_{c}-\varphi_{t}\right) d S
$$

gdje je $\mathbf{n}$ jedinična vanjska normala na površini preklapajućeg volumena $V$. Ako bi se htjela dobiti ukupna kontaktna sila na metu, tada bi se proveo isti postupak s tim da bi kontaktor i meta zamijenili uloge.

Budući da se u kombiniranoj metodi konačno-diskretnih elemenata svaki diskretni element opisuje sa svojom mrežom konačnih elemenata, volumen diskretnog elementa možemo pisati kao

$$
\beta=\beta_{1} \cup \beta_{2} \ldots \cup \beta_{i} \ldots \cup \beta_{n}
$$

Analogno volumenu, možemo i potencijal pridružen diskretnom elementu prikazati kao sumu potencijala u konačnim elementima

$$
\varphi=\varphi_{1} \cup \varphi_{2} \ldots \cup \varphi_{i} \ldots \cup \varphi_{n}
$$

Tom raspodjelom promatramo penetraciju volumena diskretnih elemenata preko prostornih konačnih elemenata. Budući da je potencijalni broj kontakata među konačnim elementima jako velik, u svrhu što bržeg proračuna kontaktnih sila kao i sila koje su posljedica deformiranja izabran je najjednostavniji prostorni konačni element, a to je četveročvorni tetraedar (Crtež 3.2). 


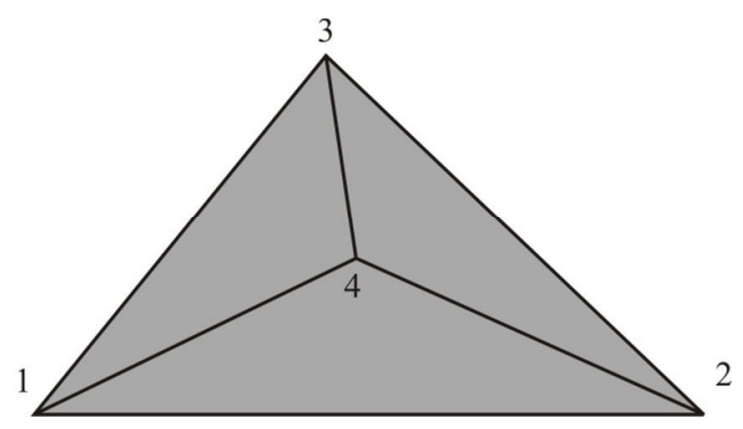

Crtež 3.2 Četveročvorni tetraedar kao konačni element za interakciju

Za tetraedre je najrazumljivije potencijal $\varphi$ definirati određivanjem središnje točke $u$ tetraedru, kao što je prikazani na crtežu 3.3. Koristeći središnju točku, tetraedar možemo podijeliti u 5 podtetraedara, te potencijal u nekoj točki P konačnog elementa na dijelu koji pripada $i-j-k-l$ podtetraedru definirati kao

$$
\varphi(P)=k\left(\frac{V_{i-j-k-p}}{4 V_{i-j-k-l}}\right)
$$

gdje $k$ predstavlja penalty parametar, $V_{i-j-k-l}$ je volumen $i-j-k-l$ podtetraedra dok je $V_{i-j-k-l-p}$ volumen koji pripada $i-j-k-l-p$ podtetraedru, tj. podtetraedru kod kojeg je jedan čvor zamijenit sa točkom P.

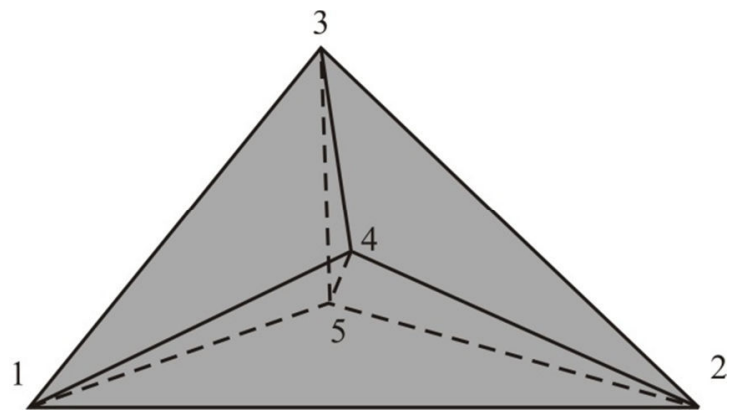

Crtež 3.3 Tetraedar sa središnjom točkom preko koje se definira potencijal [M12]

Računalni aspekt određivanja sila uslijed interakcije započinje sa identifikacijom konačnog elementa kontaktora i mete. Nadalje, definiraju se četiri pripadna podtetraedra za metu $\left(\mathrm{T}_{1}, \mathrm{~T}_{2}, \mathrm{~T}_{3}\right.$, $\mathrm{T}_{4}$ ) i za kontaktor $\left(\mathrm{t}_{1}, \mathrm{t}_{2}, \mathrm{t}_{3}, \mathrm{t}_{4}\right)$, te se provodi izračun za sve njihove kombinacije. Prvo se definira polinom presječnice baze kontaktorovog podtetraedra sa podtetraedrom mete

$$
S=\left(\mathrm{S}_{1}, \mathrm{~S}_{2}, \mathrm{~S}_{3}, \ldots, \mathrm{S}_{\mathrm{i}}, \ldots, \mathrm{S}_{\mathrm{n}}\right)
$$

kako je prikazano na crtežu 3.4. 


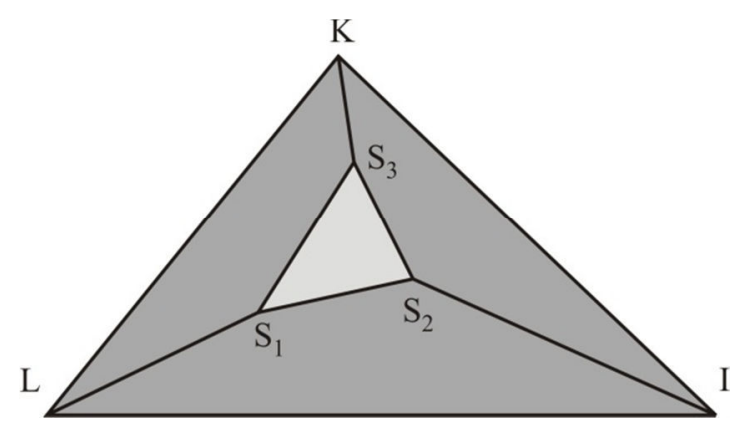

Crtež 3.4 Presječnice baze kontaktorovog podtetraedra sa podtetraedrom mete (I, J, K, L) [M12]

Nadalje, traže se točke presjecišta definiranog poligona $S$ sa bazom podtetraedra kontraktora

$$
P=\left(\mathrm{B}_{1}, \mathrm{~B}_{2}, \mathrm{~B}_{3}, \ldots, \mathrm{B}_{\mathrm{i}}, \ldots, \mathrm{B}_{\mathrm{n}}\right)
$$

kako je prikazano na crtežu 3.5 (a). U svakoj točki poligona $P$ potrebno je odrediti iznos potencijala.

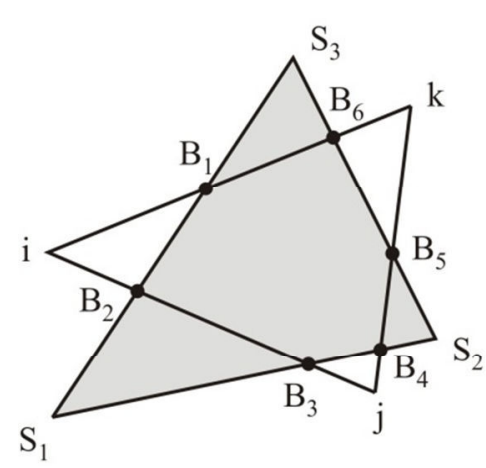

(a)

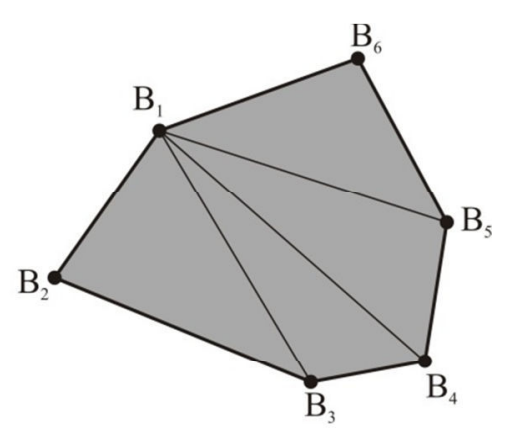

(b)

Crtež 3.5 Kontaktni poligon (a) presječnica (b) izračun kontaktnih sila [M12]

Ukupna kontaktna sila određuje se integracijom preko polinoma $P$, sumiranjem kontaktnih sila na dijelovima trokuta, kako je prikazano na crtežu 3.5(b). Kontaktne sile dalje se prenose u ekvivalentne čvorne sile na pripadajućim podtetraedrima, gdje se množe sa jediničnim vektorima normale baze kontaktora. Potrebno je napomenutu kako svakom raspodjelom sila dio sile pripada središnjoj točki tetraedra, što se također ekvivalentno prenosi u vanjske čvorove.

Ovdje predočeni postupak ponavlja se za svaki tetraedar dva puta, jednom kao za kontaktor, i jednom kao za metu. 


\subsection{DEFORMABILNOST KONAČNIH ELEMENATA}

U sklopu MKDE svaki diskretni element opisan je sa svojom mrežom konačnih elemenata. Takav pristup omogućava analizu deformabilnosti diskretnog elementa promatrajući deformabilnost njegovih konačnih elemenata. Pomaci deformabilnog tijela u svakom vremenskom trenutku ispunjavaju uvjete kontinuiteta, a to znači da će skup materijalnih točaka koje su u početnoj konfiguraciji formirale zatvorenu glatku krivulju formirati zatvorenu glatku krivulju u bilo kojem vremenskom trenutku u deformiranoj konfiguraciji. Zbog potrebe za što jednostavnijim i bržim algoritmom, te učinkovitom reprezentacijom proizvoljne prostorne geometrije, za opisivanje prostornih diskretnih elemenata odabrani su trokutasti tročvorni konačni elementi.

Deformiranje trokutastog tročvornog konačnog elementa prikazano je na crtežu 3.6. Kako bismo opisali prikazanu deformaciju i uspješno uspostavili vezu između naprezanja i deformacija, usvojena su tri koordinatna sustava također prikazana na crtežu 3.6.

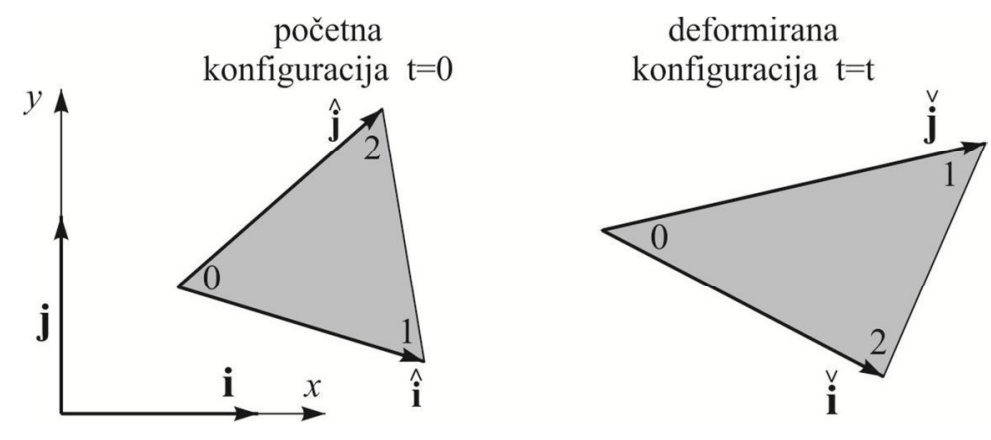

Crtež 3.6 Trokutni tročvorni konačni element u početnoj i deformiranoj konfiguraciji [M12]

Bazni vektori početne konfiguracije $(\hat{\mathbf{i}}, \hat{\mathbf{j}})$ mogu se izraziti preko baznih vektora deformirane početne konfiguracije $(\breve{\mathbf{i}}, \breve{\mathbf{j}})$

$$
\begin{aligned}
& \hat{\mathbf{i}}=\hat{i}_{\breve{x}} \breve{\mathbf{i}}+\hat{i}_{\breve{y}} \breve{\mathbf{j}} \\
& \hat{\mathbf{j}}=\hat{j}_{\breve{x}} \breve{\mathbf{i}}+\hat{j}_{\breve{y}} \breve{\mathbf{j}}
\end{aligned}
$$

Analogno, bazni vektori deformirane početne konfiguracije mogu se izraziti preko baznih vektora početne konfiguracije

$$
\begin{aligned}
& \breve{\mathbf{i}}=\breve{i}_{\widehat{x}} \hat{\mathbf{i}}+\breve{i}_{\hat{y}} \hat{\mathbf{j}} \\
& \breve{\mathbf{j}}=\breve{j}_{\hat{x}} \hat{\mathbf{i}}+\breve{j}_{\hat{y}} \hat{\mathbf{j}}
\end{aligned}
$$


Kao što je poznato, polje pomaka nad trokutastim tročvornim elementom opisano je linearnim funkcijama oblika

$$
\begin{aligned}
& x_{c}=\alpha_{x} x_{i}+\beta_{x} y_{i} \\
& y_{c}=\alpha_{y} x_{i}+\beta_{y} y_{i}
\end{aligned}
$$

gdje su $x_{c}$ i $y_{c}$ trenutne koordinate $\mathrm{u}$ deformiranoj konfiguraciji, a $x_{i}$ i $y_{i}$ početne koordinate $\mathrm{u}$ nedeformiranoj konfiguraciji. Kao rezultat toga, konačni elementi imaju konstantan gradijent deformiranja u svim točkama elementa i konstantne parcijalne derivacije pomaka po $x$ i $y$. Gradijent deformiranja F najjednostavnije je izračunati na početnoj deformiranoj konfiguraciji $(\hat{\mathbf{i}}, \hat{\mathbf{j}})$

$$
\mathbf{F}=\left[\begin{array}{ll}
\frac{\partial x_{c}}{\partial \bar{x}_{i}} & \frac{\partial x_{c}}{\partial \bar{y}_{i}} \\
\frac{\partial y_{c}}{\partial \bar{x}_{i}} & \frac{\partial y_{c}}{\partial \bar{y}_{i}}
\end{array}\right]
$$

gdje su $x_{c}$ i $y_{c}$ trenutne koordinate u globalnom koordinatnom sustavu (i, j), dok su $\hat{x}_{i}$ i $\hat{y}_{i}$ koordinate definirane u deformiranom lokalnom koordinatnom sustavu. Ako se npr. uzme član $\partial x_{c} / \partial \bar{x}_{i}$, tada bi se on po matematičkoj formulaciji, uzimajući u obzir da je

$$
\begin{aligned}
& x_{c}=x_{c}\left(\hat{x}_{i}, \hat{y}_{i}\right) \\
& y_{c}=y_{c}\left(\hat{x}_{i}, \hat{y}_{i}\right)
\end{aligned}
$$

izračunao na način

$$
\frac{\partial x_{c}}{\partial \hat{x}_{i}}=\lim _{\Delta \hat{x}_{i} \rightarrow 0} \frac{x_{c}\left(\hat{x}_{i}+\Delta \hat{x}_{i}, \hat{y}_{i}\right)-x_{c}\left(\hat{x}_{i}, \hat{y}_{i}\right)}{\Delta \hat{x}_{i}}
$$

Budući da je gradijent deformiranja $\mathbf{F}$ konstantan, u prethodnom izrazu nije potrebno da $\Delta \widehat{x}_{i}$ teži prema nuli već se može uzeti neka konačna duljina, pa se može pisati

$$
\frac{\partial x_{c}}{\partial \bar{x}_{i}}=\frac{x_{1 c}-x_{0 c}}{|\hat{\mathbf{i}}|}
$$

gdje su $x_{1 c}$ i $x_{0 c} x$ koordinate čvora 1 i 0 u trenutnoj konfiguraciji. Slično se može pokazati i za ostale članove tenzora $\mathbf{F}$ iz čega slijedi 


$$
\mathbf{F}=\left[\begin{array}{ll}
\frac{x_{1 c}-\mathbf{x}_{0 c}}{|\hat{\mathbf{i}}|} & \frac{x_{2 c}-x_{0 c}}{|\hat{\mathbf{j}}|} \\
\frac{y_{1 c}-y_{0 c}}{|\hat{\mathbf{i}}|} & \frac{y_{2 c}-y_{0 c}}{|\hat{\mathbf{j}}|}
\end{array}\right]
$$

Da bi se izračunao član tenzora $\mathbf{F}$ npr. $\partial x_{c} / \partial x_{i}$, to se može napraviti usmjerenim deriviranjem

$$
\frac{\partial x_{c}}{\partial x_{i}}=\frac{\partial x_{c}}{\partial \bar{x}_{i}} \frac{\partial \hat{x}_{i}}{\partial x_{i}}+\frac{\partial x_{c}}{\partial \hat{y}_{i}} \frac{\partial \hat{y}_{i}}{\partial x_{i}}
$$

Slično se može napraviti i s ostalim članovima tenzora $\mathbf{F}$

$$
\begin{aligned}
& \frac{\partial x_{c}}{\partial y_{i}}=\frac{\partial x_{c}}{\partial \bar{x}_{i}} \frac{\partial \bar{x}_{i}}{\partial y_{i}}+\frac{\partial x_{c}}{\partial \hat{y}_{i}} \frac{\partial \hat{y}_{i}}{\partial y_{i}} \\
& \frac{\partial y_{c}}{\partial x_{i}}=\frac{\partial y_{c}}{\partial \bar{x}_{i}} \frac{\partial \bar{x}_{i}}{\partial x_{i}}+\frac{\partial y_{c}}{\partial \hat{y}_{i}} \frac{\partial \hat{y}_{i}}{\partial x_{i}} \\
& \frac{\partial y_{c}}{\partial y_{i}}=\frac{\partial y_{c}}{\partial \bar{x}_{i}} \frac{\partial \bar{x}_{i}}{\partial y_{i}}+\frac{\partial y_{c}}{\partial \hat{y}_{i}} \frac{\partial \hat{y}_{i}}{\partial y_{i}}
\end{aligned}
$$

što dovodi do gradijenta deformiranja u obliku

$$
\mathbf{F}=\left[\begin{array}{ll}
\frac{\partial x_{c}}{\partial x_{i}} & \frac{\partial x_{c}}{\partial y_{i}} \\
\frac{\partial y_{c}}{\partial x_{i}} & \frac{\partial y_{c}}{\partial y_{i}}
\end{array}\right]=\left[\begin{array}{ll}
\frac{\partial x_{c}}{\partial \hat{x}_{i}} & \frac{\partial x_{c}}{\partial \hat{y}_{i}} \\
\frac{\partial y_{c}}{\partial \hat{x}_{i}} & \frac{\partial y_{c}}{\partial \hat{y}_{i}}
\end{array}\right]\left[\begin{array}{ll}
\frac{\partial \widehat{x}_{i}}{\partial x_{i}} & \frac{\partial \hat{x}_{i}}{\partial y_{i}} \\
\frac{\partial \hat{y}_{i}}{\partial x_{i}} & \frac{\partial \hat{y}_{i}}{\partial y_{i}}
\end{array}\right]
$$

Koristeći izraz (3.18), gradijent deformiranja može biti zapisan u obliku

$$
\mathbf{F}=\left[\begin{array}{ll}
\frac{\partial x_{c}}{\partial x_{i}} & \frac{\partial x_{c}}{\partial y_{i}} \\
\frac{\partial y_{c}}{\partial x_{i}} & \frac{\partial y_{c}}{\partial y_{i}}
\end{array}\right]=\left[\begin{array}{ll}
x_{1 c}-x_{0 c} & x_{2 c}-x_{0 c} \\
y_{1 c}-y_{0 c} & y_{2 c}-y_{0 c}
\end{array}\right]\left[\begin{array}{ll}
\frac{1}{|\hat{\mathbf{i}}|} \frac{\partial \hat{x}_{i}}{\partial x_{i}} & \frac{1}{|\hat{\mathbf{i}}|} \frac{\partial \hat{x}_{i}}{\partial y_{i}} \\
\frac{1}{|\hat{\mathbf{j}}|} \frac{\partial \hat{y}_{i}}{\partial x_{i}} & \frac{1}{|\hat{\mathbf{j}}|} \frac{\partial \hat{y}_{i}}{\partial y_{i}}
\end{array}\right]
$$

Stupci drugog tenzora s desne strane predstavljaju komponente baznih normiranih vektora $(\mathbf{i}, \mathbf{j})$ zapisanih preko baznih vektora $(\hat{\mathbf{i}}, \hat{\mathbf{j}})$ što omogućuje da se prethodni izraz prikaže u obliku 


$$
\mathbf{F}=\left[\begin{array}{ll}
\frac{\partial x_{c}}{\partial x_{i}} & \frac{\partial x_{c}}{\partial y_{i}} \\
\frac{\partial y_{c}}{\partial x_{i}} & \frac{\partial y_{c}}{\partial y_{i}}
\end{array}\right]=\left[\begin{array}{ll}
\frac{\partial x_{c}}{\partial \hat{x}_{i}} & \frac{\partial x_{c}}{\partial \hat{y}_{i}} \\
\frac{\partial y_{c}}{\partial \bar{x}_{i}} & \frac{\partial y_{c}}{\partial \hat{y}_{i}}
\end{array}\right]\left[\begin{array}{ll}
i_{\widehat{x}} & j_{\widehat{x}} \\
i_{\hat{y}} & j_{\hat{y}}
\end{array}\right]
$$

Budući da je veza između deformirane $(\widehat{\mathbf{i}}, \widehat{\mathbf{j}})$ i početne konfiguracije $(\mathbf{i}, \mathbf{j})$ definirana kao

$$
\left[\begin{array}{ll}
i_{\hat{x}} & j_{\hat{x}} \\
i_{\hat{y}} & j_{\hat{y}}
\end{array}\right]=\left[\begin{array}{ll}
\hat{i}_{x} & \hat{j}_{x} \\
\hat{i}_{y} & \hat{j}_{y}
\end{array}\right]^{-1}
$$

te uzimajući u obzir da je

$$
\left[\begin{array}{ll}
\hat{i}_{x} & \hat{j}_{x} \\
\hat{i}_{y} & \hat{j}_{y}
\end{array}\right]^{-1}=\left[\begin{array}{ll}
x_{1 i}-x_{0 i} & x_{2 i}-x_{0 i} \\
y_{1 i}-y_{0 i} & y_{2 i}-y_{0 i}
\end{array}\right]^{-1}
$$

izraz (3.23) se može napisati u obliku

$$
\mathbf{F}=\left[\begin{array}{ll}
\frac{\partial x_{c}}{\partial x_{i}} & \frac{\partial x_{c}}{\partial y_{i}} \\
\frac{\partial y_{c}}{\partial x_{i}} & \frac{\partial y_{c}}{\partial y_{i}}
\end{array}\right]=\left[\begin{array}{ll}
x_{1 c}-x_{0 c} & x_{2 c}-x_{0 c} \\
y_{1 c}-y_{0 c} & y_{2 c}-y_{0 c}
\end{array}\right]\left[\begin{array}{ll}
x_{1 i}-x_{0 i} & x_{2 i}-x_{0 i} \\
y_{1 i}-y_{0 i} & y_{2 i}-y_{0 i}
\end{array}\right]^{-1}
$$

gdje su $x_{i i}$ i $y_{i i}$ koordinata $x$, odnosno $y, i$-tog čvora u početnoj konfiguraciji. Na isti način moguće je izračunati i gradijent brzine koji će, primjenjujući analogiju s tenzorom $\mathbf{F}$, imati oblik

$$
\mathbf{L}=\left[\begin{array}{ll}
\frac{\partial v_{x c}}{\partial x_{i}} & \frac{\partial v_{x c}}{\partial y_{i}} \\
\frac{\partial v_{y c}}{\partial x_{i}} & \frac{\partial v_{y c}}{\partial y_{i}}
\end{array}\right]=\left[\begin{array}{ll}
v_{x 1 c}-v_{x 0 c} & v_{x 2 c}-v_{x 0 c} \\
v_{y 1 c}-v_{y 0 c} & y_{y 2 c}-v_{y 0 c}
\end{array}\right]\left[\begin{array}{ll}
x_{1 c}-x_{0 c} & x_{2 c}-x_{0 c} \\
y_{1 c}-y_{0 c} & y_{2 i}-y_{0 c}
\end{array}\right]^{-1}
$$

Da bi došli do pripadajućih naprezanja u elementu, potrebno je razlučiti rotaciju od rastezanja elementa. Shodno tome, tenzor $\mathbf{F}$ možemo napisati kao produkt dvaju tenzora

$$
\mathbf{F}=\mathbf{V R}
$$

gdje $\mathbf{R}$ prezentira rotaciju, dok se $\mathbf{V}$ naziva lijevi tenzor rastezanja. Da bi se lijevi GreenSt.Venantov tenzor deformacija mogao razlučiti na dio koji obuhvaća promjenu volumena i na dio koji obuhvaća promjenu oblika, potrebno je gradijent deformiranja $\mathbf{F}$ napisati kao umnožak tri 
tenzora od kojih će jedan predstavljati čistu rotaciju $\mathbf{R}$, drugi promjenu oblika bez promjene volumena $\mathbf{V}_{\mathbf{d}}$, a treći promjenu volumena bez promjene oblika $\mathbf{V}_{\mathbf{s}}$

$$
\mathbf{F}=\mathbf{V}_{\mathbf{s}} \mathbf{V}_{\mathbf{d}} \mathbf{R}
$$

Važno je napomenuti da je $\operatorname{det} \mathbf{F}=\operatorname{det} \mathbf{V}_{\mathbf{s}} \mathrm{i} \operatorname{det} \mathbf{V}_{\mathbf{d}}=1$. Lijevi Green-St.Venantov tenzor deformacija može se napisati kao

$$
\begin{aligned}
\breve{\mathbf{E}} & =\frac{1}{2}\left(\mathbf{F} \mathbf{F}^{\mathbf{T}}-\mathbf{I}\right)=\frac{1}{2}\left[\left(\mathbf{V}_{\mathbf{s}} \mathbf{V}_{\mathbf{d}} \mathbf{R}\right)\left(\mathbf{V}_{\mathbf{s}} \mathbf{V}_{\mathbf{d}} \mathbf{R}\right)^{\mathbf{T}}-\mathbf{I}\right] \\
& =\frac{1}{2}\left[\mathbf{V}_{\mathbf{s}} \mathbf{V}_{\mathbf{d}} \mathbf{R R}^{\mathbf{T}} \mathbf{V}_{\mathbf{d}}^{\mathbf{T}} \mathbf{V}_{\mathbf{s}}^{\mathbf{T}}-\mathbf{I}\right] \\
& =\frac{1}{2}\left[\mathbf{V}_{\mathbf{s}} \mathbf{V}_{\mathbf{d}} \mathbf{V}_{\mathbf{d}}^{\mathbf{T}} \mathbf{V}_{\mathbf{s}}^{\mathbf{T}}-\mathbf{I}\right]
\end{aligned}
$$

Budući da tenzor $\mathbf{V}_{\mathbf{s}}$ ne uzrokuje nikakvu promjenu oblika nego samo promjenu volumena koji se uveća za ( $\operatorname{det} \mathbf{F}$ ) puta, može se zaključiti da se tenzor $\mathbf{V}_{\mathbf{s}}$ može napisati u obliku

$$
\mathbf{V}_{\mathbf{s}}=\mathbf{I} \sqrt{\operatorname{det} \mathbf{F}}
$$

jer se svaka stranica diferencijalnog elementa produlji za $\sqrt{\operatorname{det} \mathbf{F}}$ puta. Uvrštavajući izraz (3.31) u (3.30) dobije se

$$
\breve{\mathbf{E}}=\frac{1}{2}\left[\mathbf{V}_{\mathbf{d}} \mathbf{V}_{\mathbf{d}}^{\mathbf{T}}(|\operatorname{det} \mathbf{F}|)-\mathbf{I}\right]
$$

Dio lijevog Green-St.Venantovog tenzora deformacija koji se odnosi na promjenu oblika izgleda kao

$$
\breve{\mathbf{E}}_{\mathbf{d}}=\frac{1}{2}\left(\mathbf{V}_{\mathbf{d}} \mathbf{V}_{\mathbf{d}}^{\mathbf{T}}-\mathbf{I}\right)=\frac{1}{2}\left(\frac{\mathbf{F} \mathbf{F}^{\mathbf{T}}}{|\operatorname{det} \mathbf{F}|}-\mathbf{I}\right)
$$

dok dio koji se odnosi na promjenu volumena ima oblik

$$
\breve{\mathbf{E}}_{\mathbf{s}}=\frac{1}{2}\left(\mathbf{V}_{\mathbf{s}} \mathbf{V}_{\mathbf{s}}^{\mathbf{T}}-\mathbf{I}\right)=\frac{1}{2}(\mathbf{I}|\operatorname{det} \mathbf{F}|-\mathbf{I})=\mathbf{I}\left(\frac{|\operatorname{det} \mathbf{F}|-1}{2}\right)
$$

Poznavajuči gradijent deformiranja F moguće je izračunati lijevi Cauchy-Greenov tenzor deformiranja B 


$$
\mathbf{B}=\mathbf{F F}^{T}=\mathbf{V} \mathbf{V}^{T}=\left[\begin{array}{ll}
\frac{\partial x_{c}}{\partial x_{i}} & \frac{\partial x_{c}}{\partial y_{i}} \\
\frac{\partial y_{c}}{\partial x_{i}} & \frac{\partial y_{c}}{\partial y_{i}}
\end{array}\right]\left[\begin{array}{ll}
\frac{\partial x_{c}}{\partial x_{i}} & \frac{\partial y_{c}}{\partial x_{i}} \\
\frac{\partial x_{c}}{\partial y_{i}} & \frac{\partial y_{c}}{\partial y_{i}}
\end{array}\right]
$$

Na sličan način može se dobiti tenzor brzine deformiranja D dobiven iz gradijenta brzine. Budući da gradijent brzine L u sebi sadrži komponente brzine koje su posljedica brzine deformiranja i brzine rotacije, potrebno je uzeti u obzir samo simetrični dio gradijenta brzine koji sadrži komponente vezane uz brzinu deformiranja u obliku

$$
\mathbf{D}=\frac{1}{2}\left(\mathbf{L}+\mathbf{L}^{T}\right)=\frac{1}{2}\left(\left[\begin{array}{ll}
\frac{\partial v_{x c}}{\partial x_{i}} & \frac{\partial v_{x c}}{\partial y_{i}} \\
\frac{\partial v_{y c}}{\partial x_{i}} & \frac{\partial v_{y c}}{\partial y_{i}}
\end{array}\right]+\left[\begin{array}{ll}
\frac{\partial v_{x c}}{\partial x_{i}} & \frac{\partial v_{y c}}{\partial x_{i}} \\
\frac{\partial v_{x c}}{\partial y_{i}} & \frac{\partial v_{y c}}{\partial y_{i}}
\end{array}\right]\right)
$$

Iz lijevog Cauchy-Greenovog tenzora deformiranja, za male deformacije slijedi GreenSt.Venantov tenzor deformacija

$$
\breve{\mathbf{E}}=\frac{1}{2}\left(\mathbf{V}^{2}-\mathbf{I}\right)=\frac{1}{2}(\mathbf{B}-\mathbf{I})=\frac{1}{2}\left(\left[\begin{array}{ll}
\frac{\partial x_{c}}{\partial x_{i}} & \frac{\partial x_{c}}{\partial y_{i}} \\
\frac{\partial y_{c}}{\partial x_{i}} & \frac{\partial y_{c}}{\partial y_{i}}
\end{array}\right]\left[\begin{array}{ll}
\frac{\partial x_{c}}{\partial x_{i}} & \frac{\partial y_{c}}{\partial x_{i}} \\
\frac{\partial x_{c}}{\partial y_{i}} & \frac{\partial y_{c}}{\partial y_{i}}
\end{array}\right]-\left[\begin{array}{cc}
1 & 0 \\
0 & 1
\end{array}\right]\right)
$$

koji se može prikazati dijelom koji u sebi sadrži doprinos od promjene oblika

$$
\breve{\mathbf{E}}_{d}=\frac{1}{2}\left(\frac{\mathbf{V}^{2}}{|\operatorname{det} \mathbf{F}|}-\mathbf{I}\right)=\frac{1}{2}\left(\frac{\mathbf{B}}{|\operatorname{det} \mathbf{F}|}-\mathbf{I}\right)=\frac{1}{2}\left(\frac{1}{|\operatorname{det} \mathbf{F}|}\left[\begin{array}{ll}
\frac{\partial x_{c}}{\partial x_{i}} & \frac{\partial x_{c}}{\partial y_{i}} \\
\frac{\partial y_{c}}{\partial x_{i}} & \frac{\partial y_{c}}{\partial y_{i}}
\end{array}\right]\left[\begin{array}{ll}
\frac{\partial x_{c}}{\partial x_{i}} & \frac{\partial y_{c}}{\partial x_{i}} \\
\frac{\partial x_{c}}{\partial y_{i}} & \frac{\partial y_{c}}{\partial y_{i}}
\end{array}\right]-\left[\begin{array}{ll}
1 & 0 \\
0 & 1
\end{array}\right]\right)
$$

i dijelom koji doprinosi promjeni volumena

$$
\breve{\mathbf{E}}_{s}=\frac{1}{2}\left(\mathbf{V}_{\mathrm{s}} \mathbf{V}_{\mathrm{s}}^{\mathbf{T}}-\mathbf{I}\right)=\mathbf{I}\left(\frac{|\operatorname{det} \mathbf{F}|-1}{2}\right)=\left(\frac{|\operatorname{det} \mathbf{F}|-1}{2}\right)\left[\begin{array}{ll}
1 & 0 \\
0 & 1
\end{array}\right]
$$

Poznavajući tenzor deformacija, Cauchyjev tenzor naprezanja može se dobiti koristeći Hookov zakon sukladno izrazu 


$$
\boldsymbol{\sigma}=\frac{E}{(1+v)} \breve{\mathbf{E}}_{d}+\frac{E}{(1-2 v)} \breve{\mathbf{E}}_{s}+\bar{\mu} \mathbf{D}
$$

gdje je $E$ modul elastičnosti, $v$ Poissonov koeficijent, a $\bar{\mu}$ koeficijent prigušenja koji sa $\mathbf{D}$ predstavlja doprinos brzine deformiranja. Prethodni izraz može se još zapisati kao

$$
\boldsymbol{\sigma}=2 \mu \breve{\mathbf{E}}+\lambda \varepsilon_{v} \mathbf{I}+\bar{\mu} \mathbf{D}
$$

gdje su $\mu$ i $\lambda$ Laméove konstante, dok je $\varepsilon_{v}$ volumenska deformacija koja je jednaka

$$
\varepsilon_{v}=\varepsilon_{x x}+\varepsilon_{y y}+\varepsilon_{z z}
$$

Sila po jedinci duljine stranice trokutnog elementa (s) u deformiranoj konfiguraciji može se izračunati pomoću komponenti jedinične normale položene na stranicu trokuta $u$ deformiranoj konfiguraciji (n), prikazanoj na crtežu 3.7.

$$
\mathbf{s}=\boldsymbol{\sigma} \mathbf{n}=\left\{\begin{array}{l}
s_{x} \\
s_{y}
\end{array}\right\}=\left[\begin{array}{ll}
\sigma_{x x} & \sigma_{x y} \\
\sigma_{y x} & \sigma_{y y}
\end{array}\right]\left\{\begin{array}{l}
n_{x} \\
n_{y}
\end{array}\right\}
$$

Sila po jedinici duljine stranice trokutnog elementa koja pripada pojedinom čvoru definirana je izrazom

$$
\mathbf{f}=\frac{1}{2} \mathbf{s}=\frac{1}{2}\left\{\begin{array}{l}
s_{x} \\
s_{y}
\end{array}\right\}=\frac{1}{2}\left[\begin{array}{ll}
\sigma_{x x} & \sigma_{x y} \\
\sigma_{y x} & \sigma_{y y}
\end{array}\right]\left\{\begin{array}{l}
n_{x} \\
n_{y}
\end{array}\right\}
$$

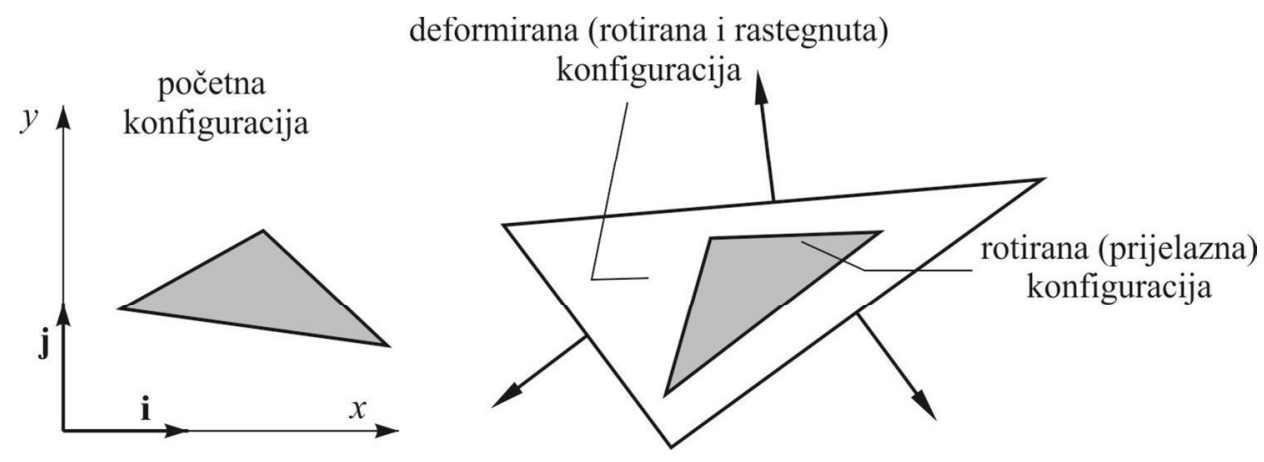

Crtež 3.7 Vektori normale na trokut [M12] 


\subsection{VREMENSKA DISKRETIZACIJA}

U kombiniranoj metodi konačno-diskretnih elemenata svaki diskretni element diskretiziran je sa svojom mrežom konačnih elemenata. Kao što je već navedeno, u okvirima ove radnje korištena je diskretizacija pomoću trokutastih tročvornih konačnih elemenata. Oblik i položaj diskretnog elementa tada možemo opisati trenutnim koordinatama čvorova konačnih elemenata u obliku

$$
\mathbf{x}=\left[\begin{array}{c}
x_{1} \\
x_{2} \\
x_{3} \\
\cdots \\
x_{i} \\
\cdots \\
x_{n}
\end{array}\right]
$$

gdje $n$ predstavlja ukupan broj stupnjeva slobode predmetnog diskretnog elementa. Analogno, polje brzina nad diskretnim elementom definirano je brzinama u čvorovima konačnih elemenata

$$
\mathbf{v}=\dot{\mathbf{x}}=\left[\begin{array}{c}
\dot{x}_{1} \\
\dot{x}_{2} \\
\dot{x}_{3} \\
\cdots \\
\dot{x}_{i} \\
\cdots \\
\dot{x}_{n}
\end{array}\right]
$$

dok je polje ubrzanja nad diskretnim elementom definirano ubrzanjima u čvorovima konačnih elemenata

$$
\mathbf{a}=\ddot{\mathbf{x}}=\left[\begin{array}{c}
\ddot{x}_{1} \\
\ddot{x}_{2} \\
\ddot{x}_{3} \\
\cdots \\
\ddot{x}_{i} \\
\cdots \\
\ddot{x}_{n}
\end{array}\right]
$$


Da bi se uzeli u obzir inercijalni efekti, u proračun je potrebno uvesti masu koja je u kombiniranoj metodi konačno-diskretnih elemenata koncentrirana u čvorove konačnih elemenata (crtež 3.8). Taj pristup nam znači da se masa, umjesto raspodijele po cijelom diskretnom elementu, pretpostavlja isključivo koncentrirano i to u čvorovima konačnih elemenata.

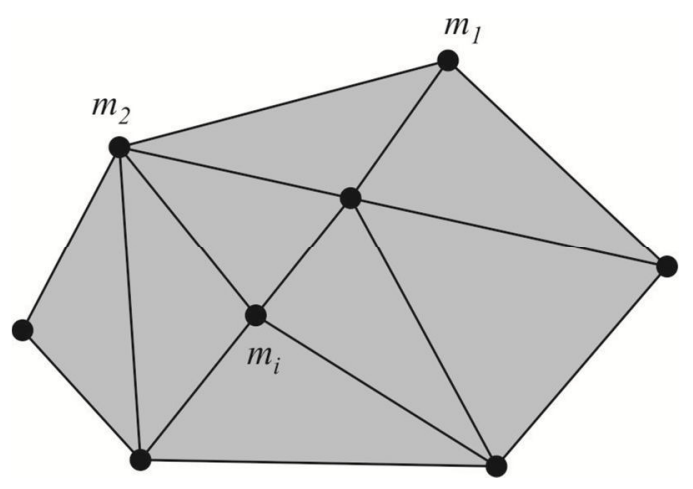

Crtež 3.8 Model koncentriranih masa

Analogno koordinatama, brzinama i ubrzanjima, masu koja pripada određenim stupnjevima slobode možemo prikazati kao

$$
\mathbf{m}=\left[\begin{array}{c}
m_{1} \\
m_{2} \\
m_{3} \\
\ldots \\
m_{i} \\
\cdots \\
m_{n}
\end{array}\right]
$$

Ukupna sila koje se javlja u čvoru konačnog elemenata posljedica je:

- interakcije između dva ili više diskretnih elemenata u kontaktu,

- deformiranja konačnog elementa,

- djelujućih vanjskih opterećenja,

- prigušenja (bilo vanjskog ili unutrašnjeg).

Zbrajanjem tih sila u svakom čvoru diskretnog elementa dobivamo raspodjelu sila po elementu koju možemo prikazati kao 


$$
\mathbf{f}=\left[\begin{array}{c}
f_{1} \\
f_{2} \\
f_{3} \\
\cdots \\
f_{i} \\
\cdots \\
f_{n}
\end{array}\right]
$$

Poznavanje sila u čvorovima omogućava nam sklapanje jednadžbe dinamičke ravnoteže sustava

$$
\left[\begin{array}{ccccccc}
m_{1} & & & & & & \\
& m_{1} & & & & & \\
& & m_{2} & & & & \\
& & & \ldots & & & \\
& & & m_{i} & & \\
& & & & \ldots & \\
& & & & & m_{n}
\end{array}\right]\left[\begin{array}{c}
\ddot{x}_{1} \\
\ddot{x}_{2} \\
\ddot{x}_{3} \\
\ldots \\
\ddot{x}_{i} \\
\ldots \\
\ddot{x}_{n}
\end{array}\right]=\left[\begin{array}{c}
f_{1} \\
f_{2} \\
f_{3} \\
\ldots \\
f_{i} \\
\ldots \\
f_{n}
\end{array}\right]
$$

Ukoliko ne dolazi do pojave procesa loma matrica masa može se smatrati konstantnom, dok je vektor čvornih sila funkcija čvornih koordinata i brzina. U okvirima ovdje predstavljene metode za integraciju prethodne jednadžbe u vremenu izabrana je eksplicitna metoda konačnih razlika [M12], koja je uvjetno stabilna i čija stabilnost i točnost ovisi o izboru vremenskog koraka. Osnovna shema metode konačnih razlika može se prikazati u obliku

$$
\begin{gathered}
\mathbf{v}_{t+\Delta t / 2}=\mathbf{v}_{t-\Delta t / 2}+\Delta t \mathbf{m}^{-1} \mathbf{f}_{t} \\
\mathbf{x}_{t+\Delta t}=\mathbf{x}_{t}+\Delta t \mathbf{v}_{t+\Delta t / 2}
\end{gathered}
$$

gdje je $\mathbf{v}_{t+\Delta t / 2}$ vektor čvornih brzina u trenutku $(t+\Delta t / 2), \mathbf{v}_{t-\Delta t / 2}$ vektor brzina $\mathrm{u}$ trenutku ( $t-\Delta t / 2), \mathbf{f}_{t}$ vektor čvornih sila u položaju $\mathbf{x}_{t}, \mathbf{m}$ matrica masa, $\mathbf{x}_{t+\Delta t}$ vektor koordinata čvorova u trenutku $t+\Delta t, \mathbf{x}_{t}$ vektor koordinata čvorova u trenutku $t, \Delta t$ vremenski korak.

Iz izraza (3.50) može se uočiti da u kombiniranoj metodi konačno-diskretnih elemenata nema rješavanja sustava jednadžbi, već se vremenska integracija jednadžbi gibanja u vremenu, uz primjenu modela koncentriranih masa i eksplicitne integracijske metode, svodi na rješavanje $n$ linearnih jednadžbi za svaki vremenski korak. 


\section{NUMERIČKI MODEL ZA ANALIZU KONSTRUKCIJA LUKOVA}

U okviru ovog poglavlja detaljno je opisan numerički model za analizu konstrukcija lukova, razvijen u sklopu kombinirane metode konačno-diskretnih elemenata. Kako u okvirima ove metode nema potrebe za sastavljanjem matrica krutosti niti matrice masa, razvoj modela se svodi na računanje čvornih sila na temelju početnih i trenutnih koordinata čvorova konačnih elemenata.

U daljnjem tekstu nalazi se detaljni prikaz konačnog elemenata, diskretizacije te mehanizama nosivosti uzdužnih i poprečnih deformacija lučnih konstrukcija. Da bi se omogućila numerička analiza, ovdje prezentirani model implementiran je u kompjuterski program Y-3D [M12]. Razvijeni su algoritmi koji u svakom vremenskom koraku uključuju praćenje stanja naprezanja i deformacija u konačnom elementu, integraciju jednadžbe gibanja u vremenu koja uključuje velike pomake i rotacije te vizualizaciju spomenutih efekata. Također, provedena je i validacija numeričkog modela prikazana na nekoliko jednostavnih primjera koji obuhvaćaju validaciju mehanizma nosivosti uzdužnih i poprečnih deformacija, njihovu interakcije te analizu stabilnosti konstrukcije. 


\subsection{NUMERIČKI MODEL LUKOVA}

Geometrija luka je, u okviru ovdje predloženog numeričkog modela, predstavljena pomoću najjednostavnijih ravnih dvočvornih konačnih elemenata, kao što je prikazano na crtežu 4.1. Masa konstrukcije koncentrirana je u čvorovima konačnih elemenata. Pri tome, svakom čvoru pripada masa od polovice njemu susjednih konačnih elemenata.
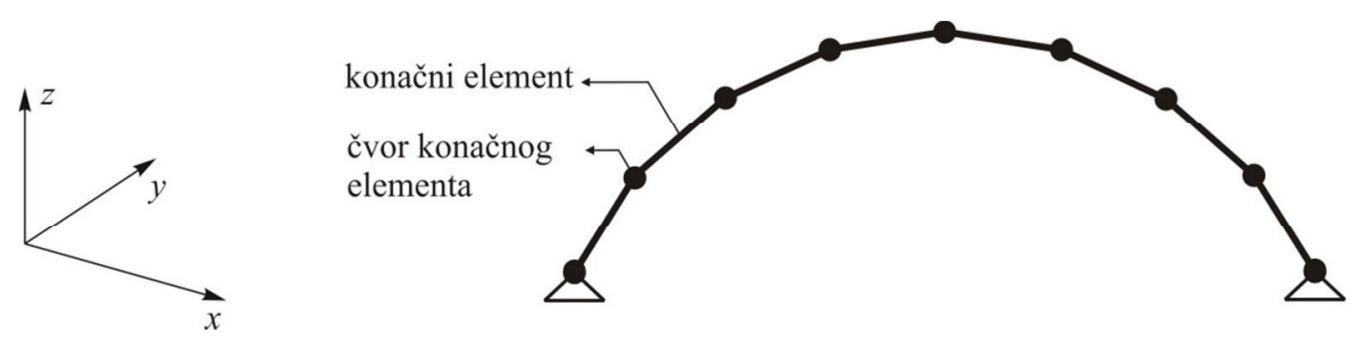

Crtež 4.1 Diskretizacija konstrukcije luka

Svaki konačni element definiran je globalnim kartezijevim koordinatama pripadajućih čvorova u početnoj i trenutnoj konfiguraciji, kao što je prikazano na crtežu 4.2.

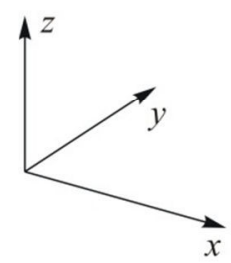

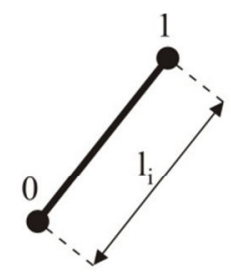

početna konfiguracija

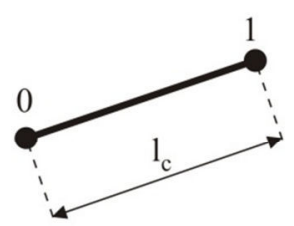

trenutna konfiguracija

Crtež 4.2 Početna i trenutna konfiguracija dvočvornog konačnog elementa

Budući da se kod lukova prijenos opterećenja odvija kombiniranim djelovanjem uzdužne i savojne krutosti, tako su i čvorne sile u ovom numeričkom modelu računate odvojeno, od uzdužne i od poprečne deformacije.

Poznavajući početne i trenutne koordinate elementa moguće je izračunati uzdužnu deformaciju

$$
\varepsilon=\left(l_{c}-l_{i}\right) / l_{i}
$$

iz čega proizlazi pripadajuće naprezanje

$$
\sigma=E \varepsilon+\bar{\mu} \dot{\varepsilon}
$$

gdje je $E$ modul elastičnosti, $\bar{\mu}$ koeficijent prigušenja dok je $\dot{\varepsilon}$ brzina promjene naprezanja. Naprezanje se dalje prevodi u odgovarajuće čvorne sile 


$$
f_{0}=f_{1}=\sigma A
$$

u smjeru osi konačnog elementa, kao što je prikazano na crtežu 4.3.
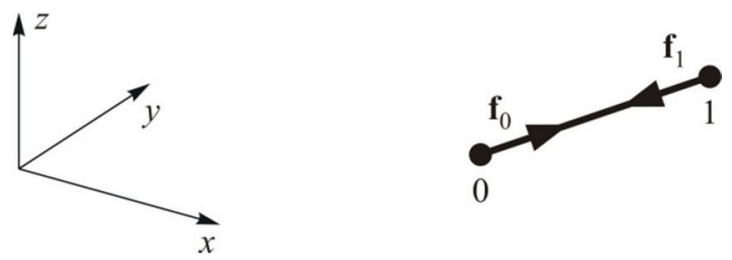

Crtež 4.3 Čvorne sile uslijed uzdužne deformacije dvočvornog konačnog elementa

Sile uslijed savojne deformacije luka računaju se ovisno o promjeni zakrivljenosti konstrukcije. Da bi se izračunala zakrivljenost potrebno je svaki čvor promatrati skupa sa njemu susjednim čvorovima, kao što je prikazano na crtežu 4.4 .
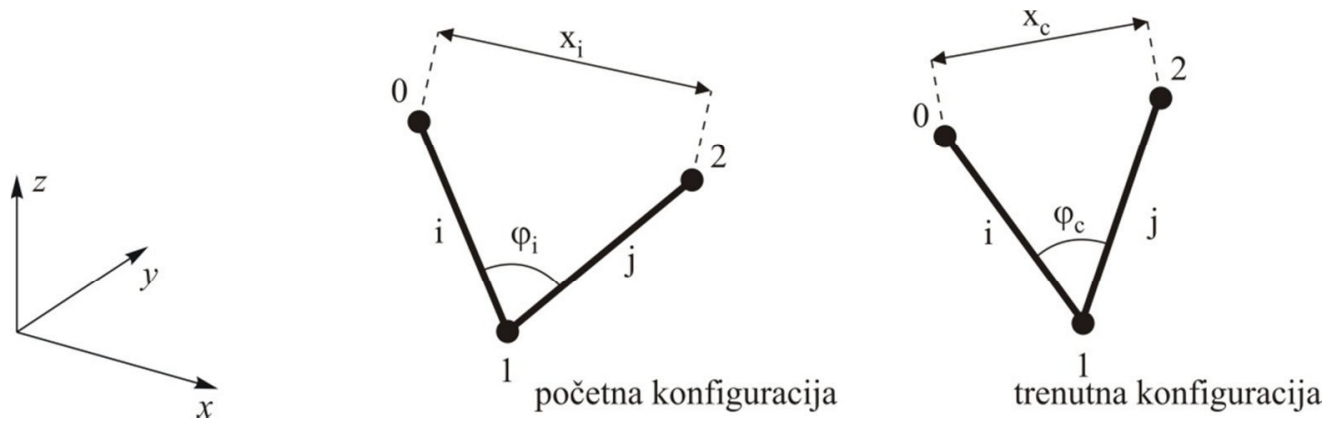

Crtež 4.4 Početna i trenutna pozicija čvora 1 sa susjednim čvorovima 0 i 2

Uzimajući u obzir matematički izraz zakrivljenosti triju točaka, početna zakrivljenost može se pisati kao

$$
\kappa_{i}=2 \frac{\sin \varphi_{i}}{x_{i}}
$$

gdje $\varphi_{i}$ predstavlja početni kut između konačnih elemenata, dok $x_{i}$ predstavlja početnu udaljenost, kao što je prikazano na crtežu 4.4. Analogno, trenutna zakrivljenost dobije se kao

$$
\kappa_{c}=2 \frac{\sin \varphi_{c}}{x_{c}}
$$

gdje $\varphi_{c}$ predstavlja početni kut između konačnih elemenata, dok $x_{c}$ predstavlja početnu udaljenost, kao što je prikazano na crtežu 4.4. Promjena zakrivljenosti na čvoru 1 definirana je kao

$$
\kappa=\kappa_{c}-\kappa_{i}
$$


Moment u čvoru 1 (crtež 4.4) može se pisati ovisno o promjeni zakrivljenosti $\kappa$ kao

$$
m=D \kappa+\mu \dot{\kappa}
$$

gdje $D$ predstavlja savojnu krutost

$$
D=E I
$$

gdje je $I$ moment inercije poprečnog presjeka konačnog elementa, $\mu$ poprečni koeficijent prigušenja, dok je $\dot{\kappa}$ brzina promjene zakrivljenosti. Savojni moment $m$ potrebno je prebaciti u ekvivalentne čvorne sile okomite na pripadajući konačni element, kao što je prikazano na crtežu 4.5 .
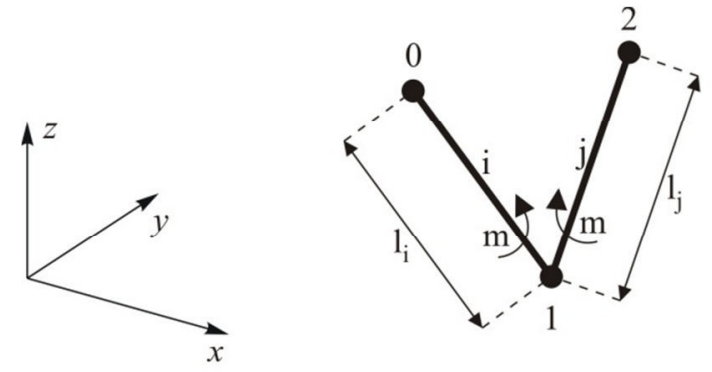

(a)

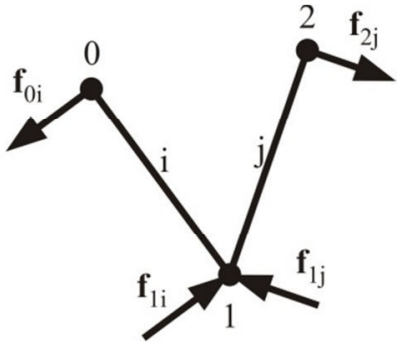

(b)

Crtež 4.5 Ekvivalentne čvorne sile uslijed savojnog momenta (a) moment (b) čvorne sile

Čvorne sile uslijed momenta u čvorovima 0,1 i 2 (crtež 4.5) iznose

$$
\begin{gathered}
f_{0 i}=f_{1 i}=\frac{m}{l_{i c}} \\
f_{1 j}=f_{2 j}=\frac{m}{l_{j c}}
\end{gathered}
$$

gdje su $l_{i c}$ i $l_{j c}$ trenutne duljine konačnih elemenata $i \mathrm{i} j$.

Za slučaj rubnih konačnih elemenata potrebno je nadomjestiti nedostatak trećeg čvora potrebnog za izraze (4.4) i (4.5). Kod zglobnih i slobodnih rubnih uvjeta moment mora biti jednak nuli, što se u predmetnom modelu reflektira na način da je promjena zakrivljenosti $\kappa$ u rubnom čvoru jednaka nuli. Kod upetih rubnih uvjeta upetost se uzima u obzir preko kružnice koja prolazi kroz rubni i prvi njemu susjedni čvor, te ima tangentu koja na rubnom čvoru odgovara i tangenti konstrukcije (crtež 4.6). Određivanjem zakrivljenosti predmetne kružnice u početnoj (crtež 4.6 (a)) 
i trenutnoj (crtež 4.6 (b)) konfiguraciji definirana je promjena zakrivljenosti $\kappa$ rubnog čvora, iz čega dalje slijedi moment na upetome rubu.

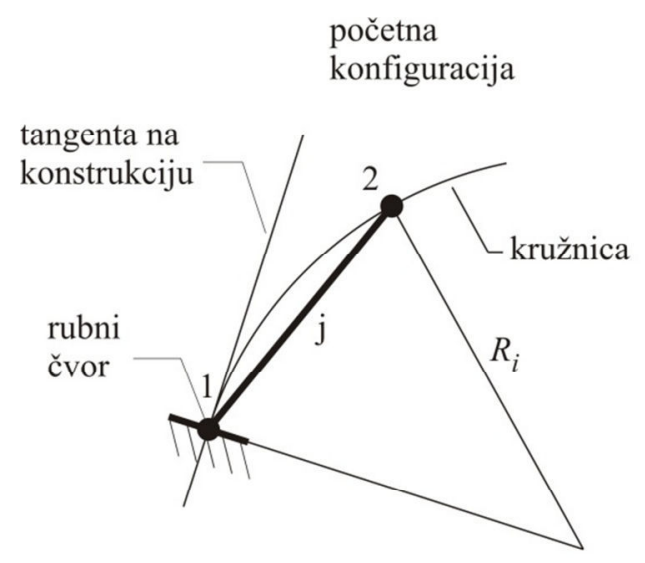

(a)

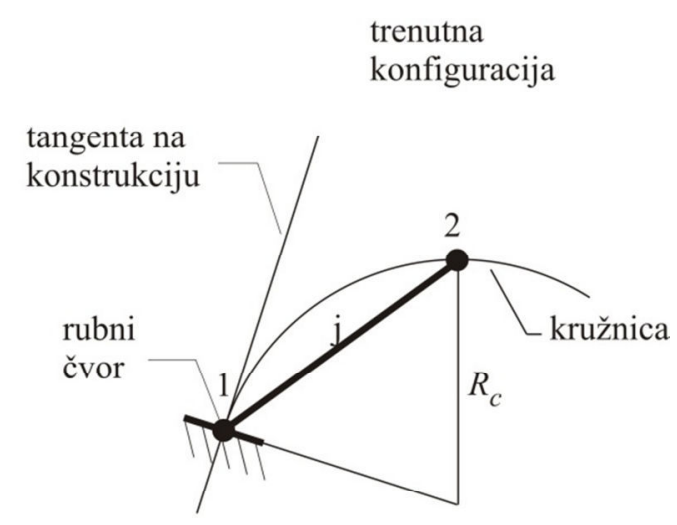

(b)

Crtež 4.6 Upeti rubni uvjet u (a) početnoj konfiguraciji (b) trenutnoj konfiguraciji

Implementacija upetosti izvršena je aproksimacijom predloženog postupka pomoću tzv. fiktivnog čvora, kako je prikazano na crtežu 4.7. Fiktivni čvor, sa nepromijenjenim koordinatama u početnoj i trenutnoj geometriji, nalazi se na kružnici koja prolazi rubnim čvorom, njemu najbližem susjednom čvoru i na rubnom čvoru ima tangentu koja odgovara tangenti konstrukcije (crtež 4.7). $\mathrm{Na}$ ovaj način zakrivljenost rubnog čvora u početnoj konfiguraciji u potpunosti odgovara stvarnoj zakrivljenosti konstrukcije, dok zakrivljenost u trenutnoj konfiguraciji uslijed pomicanja tangente bilježi odstupanja od stvarne vrijednosti. Međutim, približavanjem fiktivnog čvora rubnom čvoru dolazi do podudaranja u tangentama kružnice i konstrukcije. Može se pokazati kako kod tisuću puta manje duljine fiktivnog elementa $i$ (crtež 4.7) od konačnog elementa $j$ (crtež 4.7) odstupanje iznosi manje od $0.01 \%$.

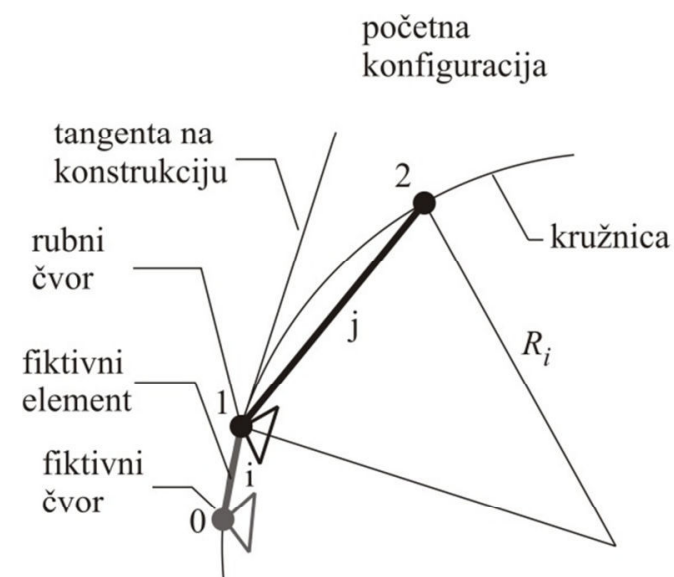

(a)

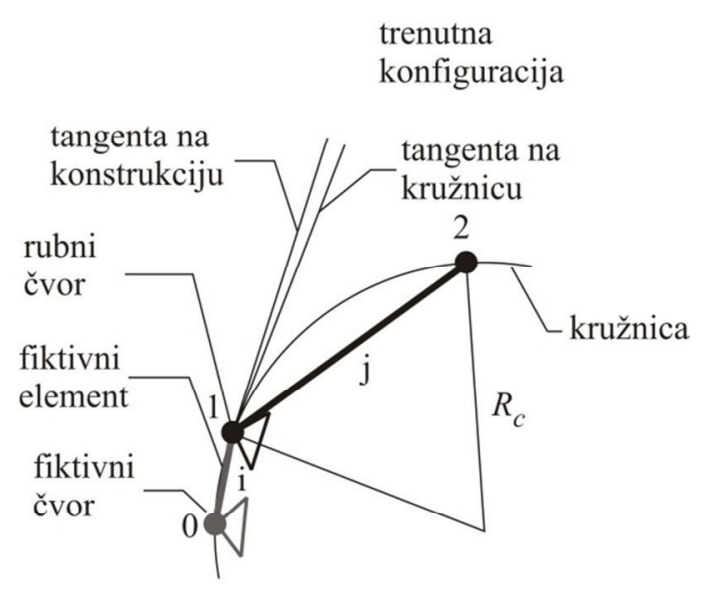

(b)

Crtež 4.7 Implementacija rubnog uvjeta u (a) početnoj konfiguraciji (b) trenutnoj konfiguraciji 
Proceduru prikazanu u ovom poglavlju potrebno je ponoviti za svaki čvor konačnog elementa. Sile uslijed uzdužnih naprezanja, kao i ekvivalentne sile uslijed momenta, pribrajaju se globalnom vektoru čvornih sila.

\subsection{VERIFIKACIJA NUMERIČKOG MODELA}

Predloženi numerički model implementiran je u open source MKDE paket - Yfdem [M12]. Verifikacija modela izvedena je nizom primjera, uspoređujući dobivene rezultate sa onima očitanima u programskom paketu ABAQUS [S10]. Prikazani su efikasnost i preciznost savojnog mehanizma, kombinacije savojnog i uzdužnog mehanizma, implementacije rubnih uvjeta upetosti, analize stabilnosti, te post-kritičnog ponašanja konstrukcije. Numerički rezultati u ABAQUS-u dobiveni su koristeći tročvorne kvadratne gredne elemente (B22), uzimajući u obzir geometrijsku nelinearnost i linearno elastično ponašanje materijala.

Da bi se osigurala dovoljna gustoća diskretizacije numeričkog rješenja u ABAQUS-u, mreža konačnih elemenata progušćivana je sve dok razlika u rješenjima dvaju uzastopnih gustoća nije bila manja od $0.005 \%$.

\subsubsection{Prosta greda pod vlastitom težinom}

Prosta greda pod opterećenjem od vlastite težine (crtež 4.8) odabrana je u svrhu validacije savojnog mehanizma predloženog modela. Greda se početno nalazi u idealno ravnoj geometriji i uslijed vlastite težine podliježe oscilacijama. Karakteristika odabranog materijala je $E=210 \mathrm{GPa}$, gustoća $\rho=7850 \mathrm{~kg} / \mathrm{m}^{3}$, dok je za konstantu gravitacije usvojeno $g=10 \mathrm{~m} / \mathrm{s}^{2}$. Širina poprečnog presjeka uzeta je kao $1 \mathrm{~m}$, dok je visina varirana u vrijednostima od $10 \mathrm{~mm}, 50 \mathrm{~mm}$ i $200 \mathrm{~mm}$.

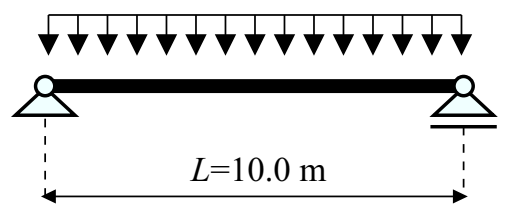

Crtež 4.8 Prosta greda pod gravitacijskim opterećenjem

Diskretizacija grede izvršena je koristeći 2, 4, 8 i 16 konačnih elemenata, što znači da je duljina konačnog elementa $l$ iznosila L/2, L/4, L/8 i L/16. Ravnotežni položaj za pojedinu diskretizaciju moguće je dobiti uvođenjem koeficijenta prigušenja, uslijed čega osciliranjem greda u konačnici zauzima ravnotežni položaj (crtež 4.9). 


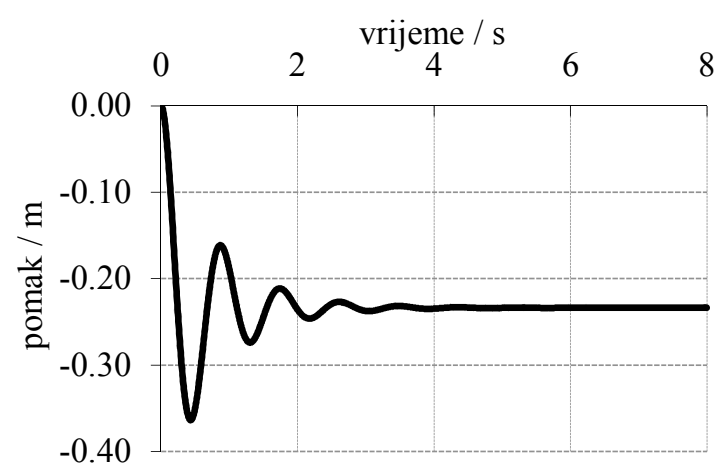

Crtež 4.9 Krivulja vrijeme-pomak na sredini raspona za $50 \mathrm{~mm}$ debelu prostu gredu diskretiziranu sa 16 konačnih elemenata i koeficijent prigušenja od $\mu=109.8 \mathrm{kNm}^{2} / \mathrm{s}$.

Ravnotežni progib na sredini grede, dobiven predloženim numeričkim modelom, uspoređen je sa numeričkim rješenjem dobivenim programskim paketom ABAQUS [S10], kako je prikazano u tablici 4.1. Numeričko rješenje iz ABAQUS-a dobiveno je upotrebom 100 tročvornih grednih elemenata.

Tablica 4.1 Progib na sredini proste grede $\mathrm{u}(\mathrm{mm})$

\begin{tabular}{|c|c|c|c|}
\hline Debljina grede & $\mathbf{1 0} \mathbf{~ m m}$ & $\mathbf{5 0} \mathbf{~ m m}$ & $\mathbf{2 0 0} \mathbf{~ m m}$ \\
\hline \hline MKDE $(l=L / 2)$ & 4070.4 & 279.935 & 17.522 \\
MKDE $(l=L / 4)$ & 3211.4 & 244.675 & 15.322 \\
MKDE $(l=L / 8)$ & 3065.5 & 235.927 & 14.784 \\
MKDE $(l=L / 16)$ & 3034.2 & 233.742 & 14.648 \\
\hline ABAQUS nelinearno & 3024.0 & 232.999 & 14.601 \\
\hline
\end{tabular}

Relativna pogreška numeričkog rezultata dobivenog predloženim MKDE modelom, $\mathrm{u}$ usporedbi sa geometrijski nelinearnim rješenjem dobivenim ABAQUS-om, prikazana je u tablici 4.2. Vidljivo je kako povećanjem broja konačnih elemenata numeričko rješenje konvergira ka rješenju dobivenom sa ABAQUS-om, te da se pogreška smanjuje sa $l^{2}$. Također je vidljivo da je utjecaj debljine grede na pogrešku zanemariv, što pokazuje kako numerički model ne pati od problema blokiranja.

Tablica 4.2 Relativna pogreška proste grede u usporedbi sa rješenjem dobivenim iz ABAQUS-a (\%)

\begin{tabular}{|c|c|c|c|}
\hline Debljina grede & $\mathbf{1 0} \mathbf{~ m m}$ & $\mathbf{5 0} \mathbf{~ m m}$ & $\mathbf{2 0 0} \mathbf{~ m m}$ \\
\hline \hline $\operatorname{MKDE}(l=L / 2)$ & 34.60 & 20.14 & 20.01 \\
$\operatorname{MKDE}(l=L / 4)$ & 6.20 & 5.01 & 4.94 \\
$\operatorname{MKDE}(l=L / 8)$ & 1.37 & 1.26 & 1.25 \\
$\operatorname{MKDE}(l=L / 16)$ & 0.34 & 0.32 & 0.32 \\
\hline
\end{tabular}

Validacija dinamičkog ponašanja grede provedena je usporedbom numeričkog rješenja za slobodne oscilacije, promatrajući pomak sredine grede dobiven predloženim MKDE modelom i 
ABAQUS paketom, kako je pokazano na crtežu 4.10. Diskretizacija unutar predloženog modela provedena je sa 16 konačnih elemenata. Iz crteža je vidljivo kako je postignuto izvrsno poklapanje rezultata.

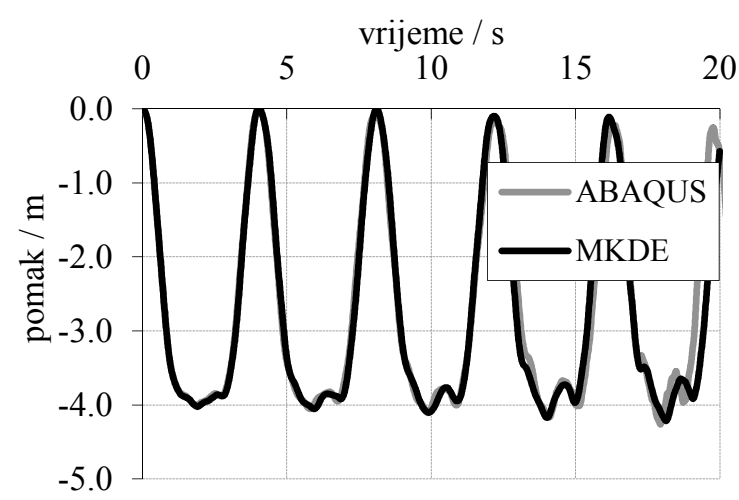

(a)

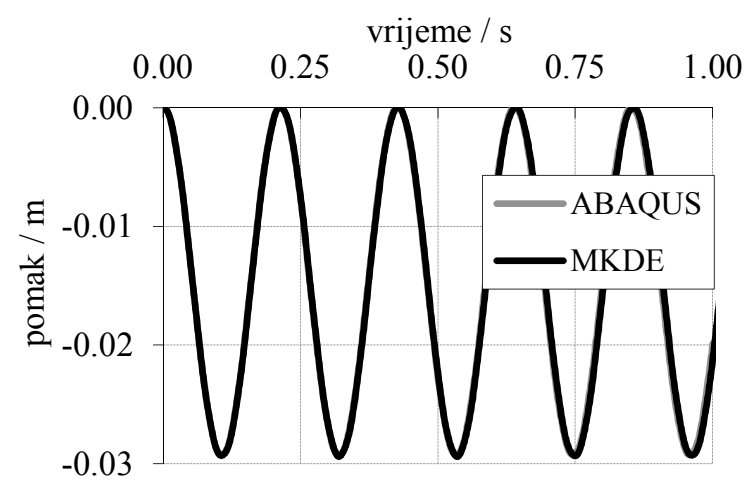

(c)

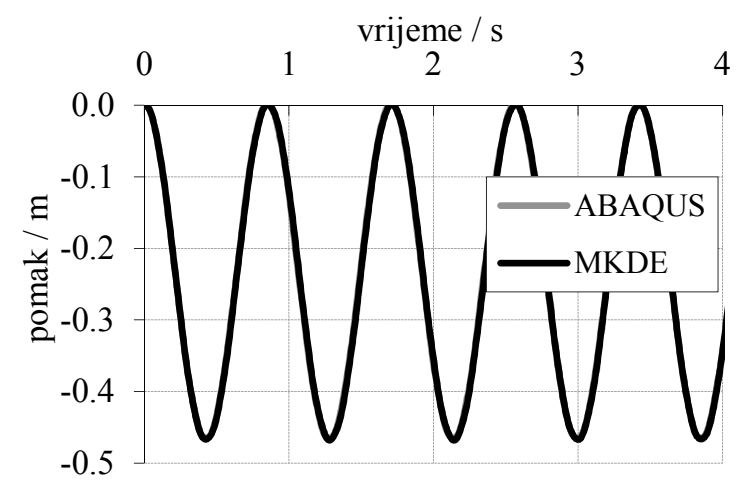

(b)

Crtež 4.10 Usporedba pomaka na sredini proste grede za slobodne oscilacije, sa debljinom grede od (a) 10 $\mathrm{mm}$, (b) $50 \mathrm{~mm}$ i (c) $200 \mathrm{~mm}$.

\subsubsection{Obostrano upeta greda pod vlastitom težinom}

Obostrano upeta greda pod opterećenjem od vlastite težine (crtež 4.11) odabrana je u svrhu validacije savojne krutosti predloženog modela za slučaj upetih rubnih uvjeta. Materijalne karakteristike, poprečni presjek i diskretizacija odgovaraju onima u prethodnom primjeru.

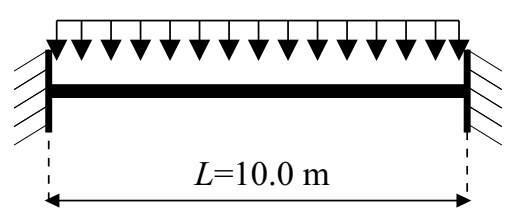

Crtež 4.11 Obostrano upeta greda pod gravitacijskim opterećenjem 
Ravnotežni progib na sredini upete grede, dobiven predloženim numeričkim modelom, uspoređen je sa numeričkim rješenjem dobivenim programskim paketom ABAQUS [S10], kako je prikazano u tablici 4.3. Numeričko rješenje iz ABAQUS-a dobiveno je koristeći 100 tročvornih grednih elemenata.

Tablica 4.3 Progib na sredini upete grede $u(\mathrm{~mm})$

\begin{tabular}{|c|c|c|c|}
\hline Debljina grede & $\mathbf{1 0} \mathbf{~ m m}$ & $\mathbf{5 0} \mathbf{~ m m}$ & $\mathbf{2 0 0} \mathbf{~ m m}$ \\
\hline \hline MKDE $(l=L / 2)$ & 55.765 & 37.562 & 3.2850 \\
MKDE $(l=L / 4)$ & 55.142 & 35.421 & 3.0112 \\
MKDE $(l=L / 8)$ & 54.463 & 34.828 & 2.9428 \\
MKDE $(l=L / 16)$ & 54.012 & 34.676 & 2.9257 \\
\hline ABAQUS nelinearno & 53.947 & 34.625 & 2.9199 \\
\hline
\end{tabular}

Relativna pogreška rezultata dobivenog sa predloženim modelom, u usporedbi sa geometrijski nelinearnim rješenjem dobivenim sa ABAQUS-om, prikazana je u tablici 4.4. Vidljivo je da kako povećanjem broja konačnih elemenata numeričko rješenje konvergira ka rješenju dobivenom sa ABAQUS-om, te da se pogreška smanjuje sa $l^{2}$. Također je vidljivo kako je utjecaj debljine grede na pogrešku zanemariv, što pokazuje da numerički model ne pati od problema blokiranja.

Tablica 4.4 Relativna pogreška upete grede u usporedbi sa rješenjem dobivenim sa ABAQUS-om (\%)

\begin{tabular}{|c|c|c|c|}
\hline Debljina grede & $\mathbf{1 0} \mathbf{~ m m}$ & $\mathbf{5 0} \mathbf{~ m m}$ & $\mathbf{2 0 0} \mathbf{~ m m}$ \\
\hline \hline MKDE $(l=L / 2)$ & 3.37 & 8.48 & 12.50 \\
$\operatorname{MKDE}(l=L / 4)$ & 2.21 & 2.30 & 3.13 \\
$\operatorname{MKDE}(l=L / 8)$ & 0.96 & 0.59 & 0.78 \\
$\operatorname{MKDE}(l=L / 16)$ & 0.12 & 0.15 & 0.20 \\
\hline
\end{tabular}

Validacija dinamičkog ponašanja upete grede provedena je usporedbom numeričkog rješenja za slobodne oscilacije, promatrajući pomak na sredini upete grede dobiven predloženim MKDE modelom i ABAQUS paketom, kako je pokazano na crtežu 4.12. Diskretizacija unutar predloženog modela provedena je sa 16 konačnih elemenata. Iz crteža je vidljivo kako je postignuto izvrsno poklapanje rezultata. 


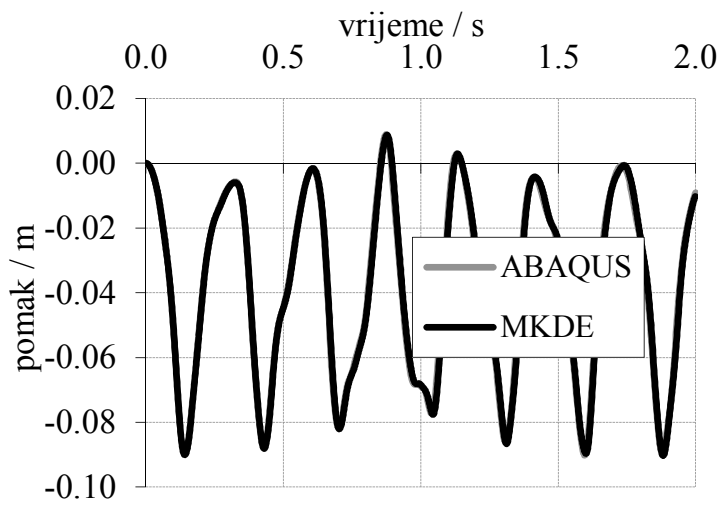

(a)

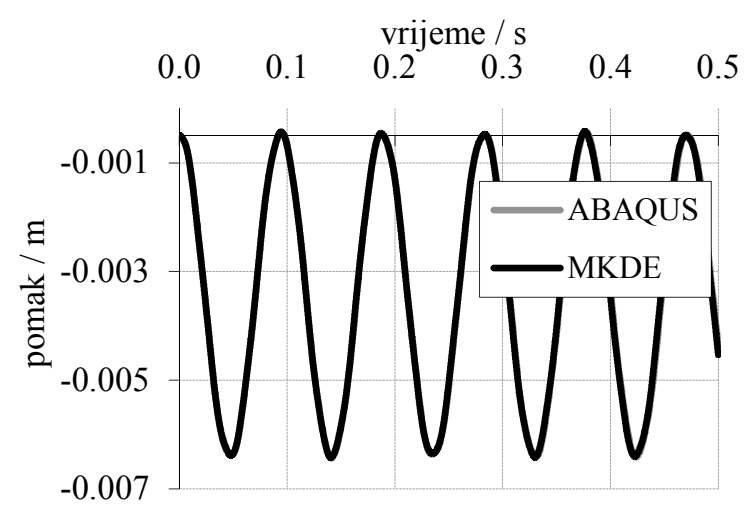

(c)

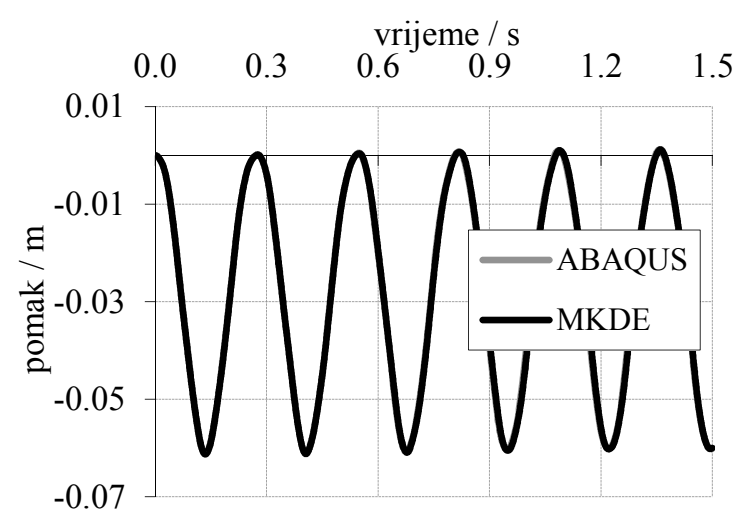

(b)

Crtež 4.12 Usporedba pomaka na sredini upete grede za slobodne oscilacije, sa debljinom grede od (a) 10 mm, (b) $50 \mathrm{~mm} \mathrm{i} \mathrm{(c)} 200 \mathrm{~mm}$.

\subsubsection{Zglobni luk pod vlastitom težinom}

Zglobni luk prikazan na crtežu 4.13, opterećen gravitacijskim opterećenjem od vlastite težine, odabran je u svrhu validacije interakcijskog djelovanja uzdužne i savojne krutosti. Materijalne karakteristike odgovaraju onima usvojenima u primjeru 4.2.1. Širina poprečnog presjeka uzeta je kao $1 \mathrm{~m}$, dok je visina varirana u vrijednostima od $25 \mathrm{~mm}, 50 \mathrm{~mm}, 100 \mathrm{~mm}$ i 200 $\mathrm{mm}$.

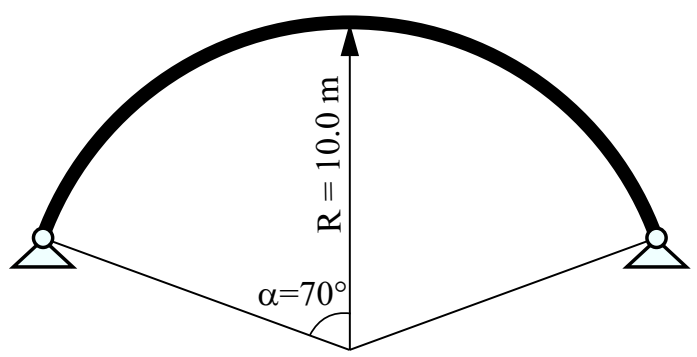

Crtež 4.13 Zglobni luk pod gravitacijskim opterećenjem 
Diskretizacija luka izvršena je koristeći 16, 32, 64 i 128 konačnih elemenata. Ravnotežni progib na sredini luka, dobiven predloženim numeričkim modelom, uspoređen je sa numeričkim rješenjem dobivenim programskim paketom ABAQUS [S10], kako je prikazano u tablici 4.5. Numeričko rješenje iz ABAQUS-a dobiveno je koristeći 244 tročvornih grednih elemenata.

Tablica 4.5 Progib na sredini zglobnog luka u (mm)

\begin{tabular}{|c|c|c|c|c|}
\hline Debljina grede & $\mathbf{2 5} \mathbf{~ m m}$ & $\mathbf{5 0} \mathbf{~ m m}$ & $\mathbf{1 0 0} \mathbf{~ m m}$ & $\mathbf{2 0 0} \mathbf{~ m m}$ \\
\hline \hline MKDE (16 elem) & 453.98 & 59.210 & 13.274 & 3.2753 \\
MKDE (32 elem) & 435.54 & 59.210 & 13.274 & 3.2753 \\
MKDE (64 elem) & 428.93 & 58.919 & 13.228 & 3.2650 \\
MKDE (128 elem) & 427.00 & 58.826 & 13.213 & 3.2615 \\
\hline ABAQUS nelinearno & 426.53 & 58.792 & 13.208 & 3.2618 \\
\hline
\end{tabular}

Relativna pogreška numeričkog rezultata dobivenog sa predloženim MKDE modelom, $\mathrm{u}$ usporedbi sa geometrijski nelinearnim rješenjem dobivenim sa ABAQUS-om, prikazana je u tablici 4.6. U tablici je vidljivo kako sa povećanjem broja konačnih elemenata numeričko rješenje konvergira ka rješenju dobivenom sa ABAQUS-om, te da se pogreška smanjuje sa $l^{2}$.

Tablica 4.6 Relativna pogreška zglobnog luka u usporedbi sa rješenjem dobivenim sa ABAQUS-om (\%)

\begin{tabular}{|c|c|c|c|c|}
\hline Debljina grede & $\mathbf{2 5} \mathbf{~ m m}$ & $\mathbf{5 0} \mathbf{~} \mathbf{m}$ & $\mathbf{1 0 0} \mathbf{~ m m}$ & $\mathbf{2 0 0} \mathbf{~ m m}$ \\
\hline \hline MKDE (16 elem) & 6.43 & 1.21 & 0.57 & 0.39 \\
MKDE (32 elem) & 2.11 & 0.71 & 0.50 & 0.41 \\
MKDE (64 elem) & 0.56 & 0.22 & 0.15 & 0.10 \\
MKDE (128 elem) & 0.11 & 0.06 & 0.04 & -0.01 \\
\hline
\end{tabular}

Validacija dinamičkog ponašanja luka provedena je usporedbom numeričkog rješenja za slobodne oscilacije, promatrajući pomak na sredini luka dobiven predloženim MKDE modelom i ABAQUS paketom, kako je pokazano na crtežu 4.14. Diskretizacija unutar predloženog modela provedena je sa 128 konačnih elemenata. Iz crteža je vidljivo kako je postignuto izvrsno poklapanje rezultata.

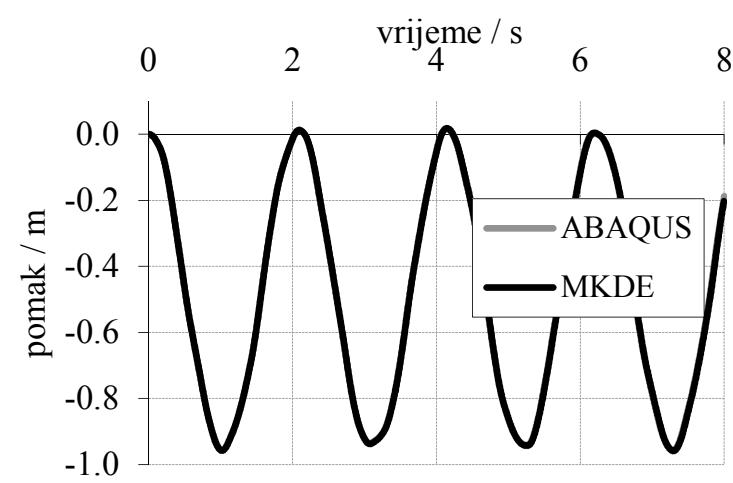

(a)

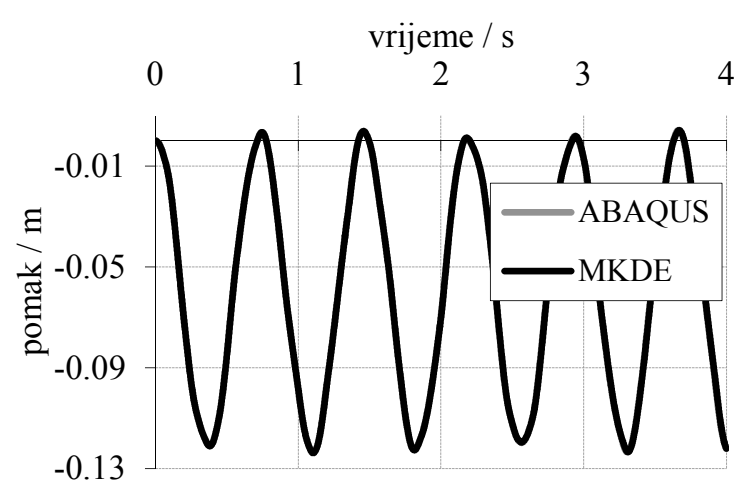

(b) 


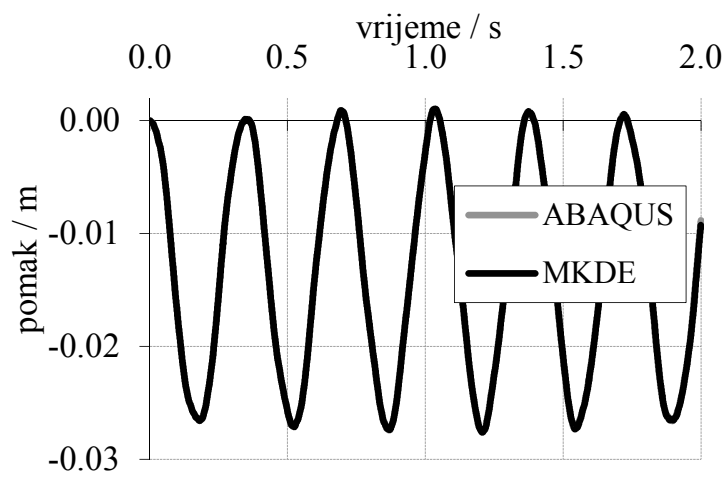

(c)

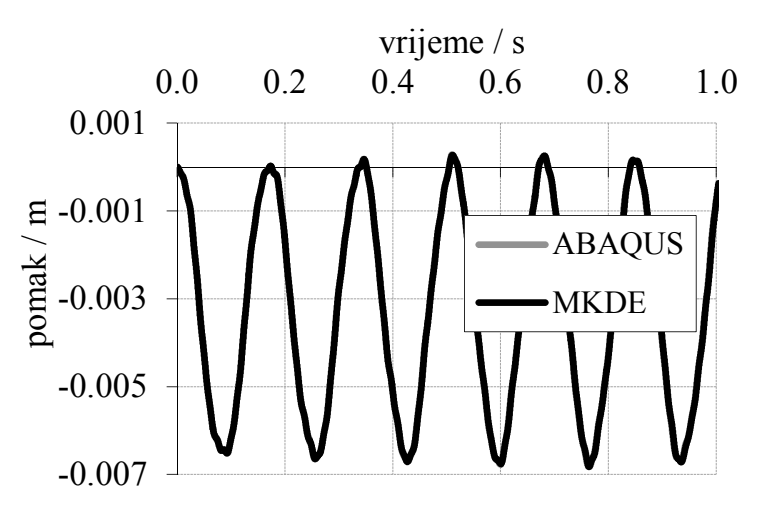

(d)

Crtež 4.14 Usporedba pomaka na sredini zglobnog luka za slobodne oscilacije, sa debljinom luka od (a) 25 $\mathrm{mm}$, (b) $50 \mathrm{~mm}$, (c) $100 \mathrm{~mm}$ i (d) $200 \mathrm{~mm}$.

\subsubsection{Upeti luk pod vlastitom težinom}

Upeti luk prikazan na crtežu 4.15, opterećen gravitacijskim opterećenjem od vlastite težine, odabran je u svrhu validacije interakcijskog djelovanja uzdužne i savojne krutosti sa upetim rubnim uvjetima. Materijalne karakteristike odgovaraju onima usvojenima u primjeru 4.2.1. Širina poprečnog presjeka uzeta je kao $1 \mathrm{~m}$, dok je visina varirana u vrijednostima od $25 \mathrm{~mm}, 50 \mathrm{~mm}$, $100 \mathrm{~mm}$ i $200 \mathrm{~mm}$.

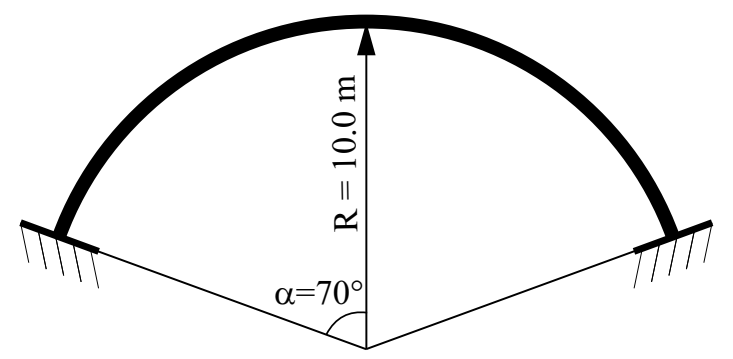

Crtež 4.15 Upeti luk pod gravitacijskim opterećenjem

Diskretizacija luka izvršena je koristeći 16, 32, 64 i 128 konačnih elemenata. Ravnotežni progib na sredini luka, dobiven predloženim numeričkim modelom, uspoređen je sa numeričkim rješenjem dobivenim programskim paketom ABAQUS [S10], kako je prikazano u tablici 4.7. Numeričko rješenje iz ABAQUS-a dobiveno je koristeći 244 tročvornih grednih elemenata.

Tablica 4.7 Progib na sredini upetog luka u (mm)

\begin{tabular}{|c|c|c|c|c|}
\hline Debljina grede & $\mathbf{2 5} \mathbf{~ m m}$ & $\mathbf{5 0} \mathbf{~ m m}$ & $\mathbf{1 0 0} \mathbf{~ m m}$ & $\mathbf{2 0 0} \mathbf{~ m m}$ \\
\hline \hline MKDE (16 elem) & 171.49 & 30.566 & 7.1910 & 1.8231 \\
MKDE (32 elem) & 152.07 & 27.605 & 6.5185 & 1.6592 \\
MKDE (64 elem) & 147.34 & 26.846 & 6.3441 & 1.6166 \\
MKDE (128 elem) & 146.17 & 26.655 & 6.3000 & 1.6058 \\
\hline ABAQUS nelinearno & 145.77 & 26.590 & 6.2853 & 1.6022 \\
\hline
\end{tabular}


Relativna pogreška numeričkog rezultata dobivenog sa predloženim MKDE modelom, $\mathrm{u}$ usporedbi sa geometrijski nelinearnim rješenjem dobivenim sa ABAQUS-om, prikazana je u tablici 4.8. U tablici je vidljivo kako sa povećanjem broja konačnih elemenata numeričko rješenje konvergira ka rješenju dobivenom sa ABAQUS-om, te da se pogreška smanjuje sa $l^{2}$.

Tablica 4.8 Relativna pogreška upetog luka u usporedbi sa rješenjem dobivenim sa ABAQUS-om (\%)

\begin{tabular}{|c|c|c|c|c|}
\hline Debljina grede & $\mathbf{2 5} \mathbf{~ m m}$ & $\mathbf{5 0} \mathbf{~ m m}$ & $\mathbf{1 0 0} \mathbf{~ m m}$ & $\mathbf{2 0 0} \mathbf{~ m m}$ \\
\hline \hline MKDE (16 elem) & 17.64 & 14.95 & 14.41 & 13.79 \\
MKDE (32 elem) & 4.32 & 3.82 & 3.71 & 3.56 \\
MKDE (64 elem) & 1.08 & 0.96 & 0.94 & 0.90 \\
MKDE (128 elem) & 0.27 & 0.24 & 0.23 & 0.22 \\
\hline
\end{tabular}

Validacija dinamičkog ponašanja luka provedena je usporedbom numeričkog rješenja za slobodne oscilacije, promatrajući pomak na sredini luka dobiven predloženim MKDE modelom i ABAQUS paketom, kako je pokazano na crtežu 4.16. Diskretizacija unutar predloženog modela provedena je sa 128 konačnih elemenata. Iz crteža je vidljivo kako je postignuto izvrsno poklapanje rezultata.

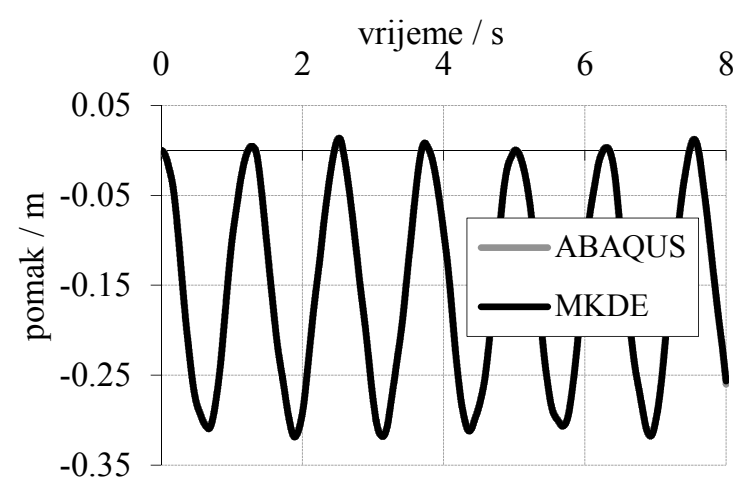

(a)

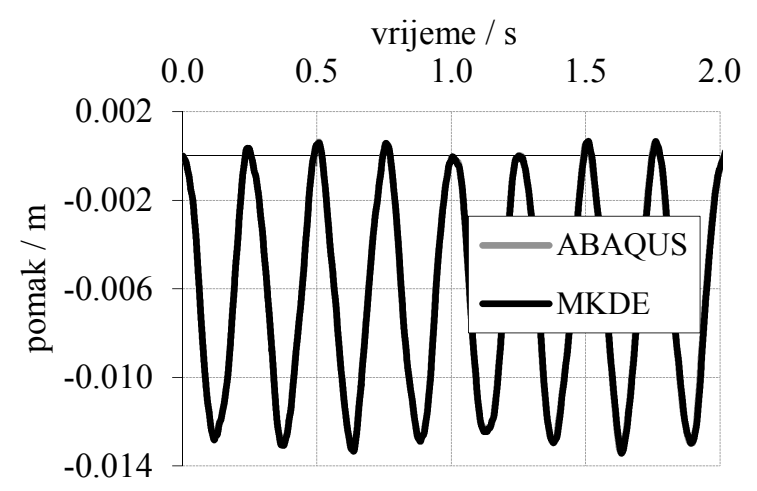

(c)

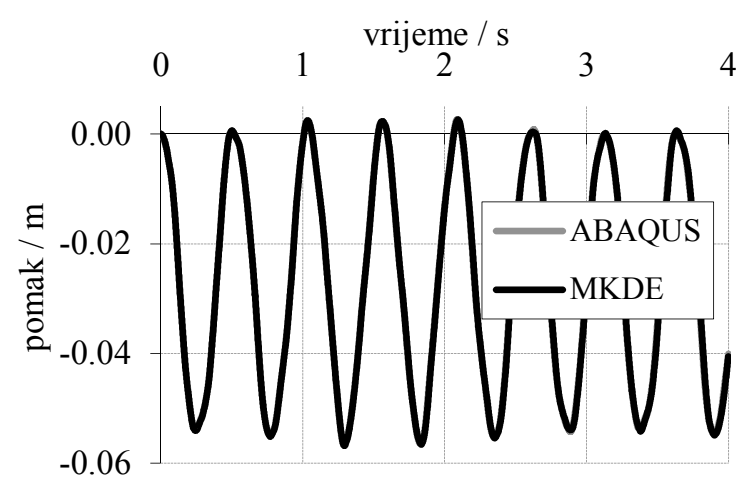

(b)

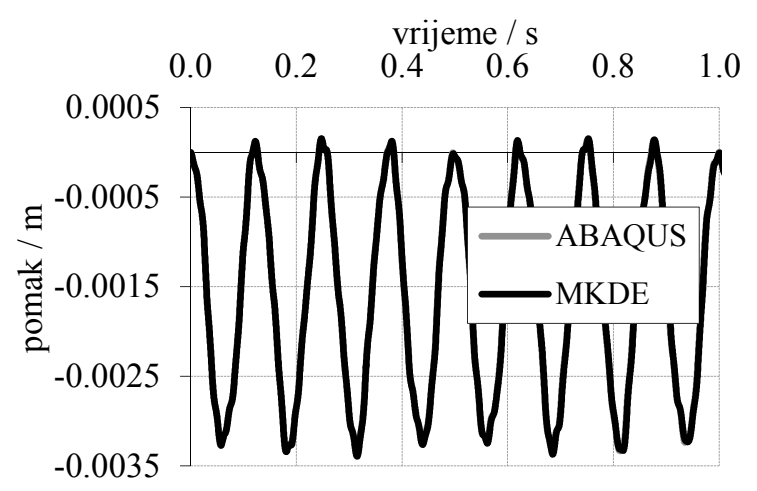

(d)

Crtež 4.16 Usporedba pomaka na sredini upetog luka za slobodne oscilacije, sa debljinom luka od (a) 25 $\mathrm{mm}$, (b) $50 \mathrm{~mm}$, (c) $100 \mathrm{~mm}$ i (d) $200 \mathrm{~mm}$. 


\subsubsection{Konzola podložena posmičnoj sili na slobodnom kraju}

Konzola podložena posmičnoj sili na slobodnom kraju, kako je prikazano na crtežu 4.17, odabrana je u svrhu validacije predloženog modela za slučajeve konačnih pomaka i rotacija. Konzola ima modul elastičnosti od $E=210 \mathrm{GPa}$, širina poprečnog presjeka iznosi $1 \mathrm{~m}$, dok je visina poprečnog presjeka $200 \mathrm{~mm}$. Diskretizacija konzole provedena je sa 16 konačnih elemenata.

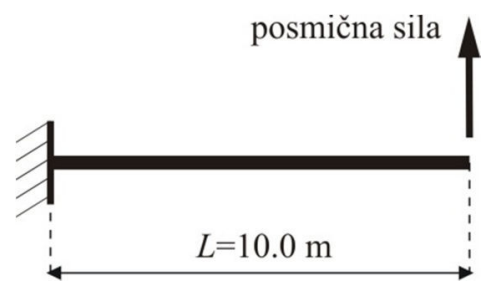

Crtež 4.17 Konzola podložena posmičnoj sili

Crtež 4.18 prikazuje dijagrame vertikalne sile na slobodnom kraju konzole u ovisnosti o vertikalnom i horizontalnom pomaku slobodnog kraja. Numerički pomak dobiven predloženim modelom uspoređen je sa rješenjem dobivenim ABAQUS paketom, koristeći 100 tročvornih grednih elemenata.

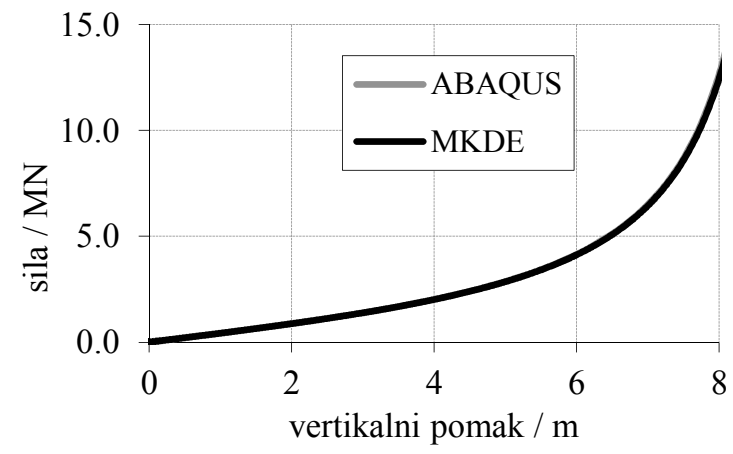

(a)

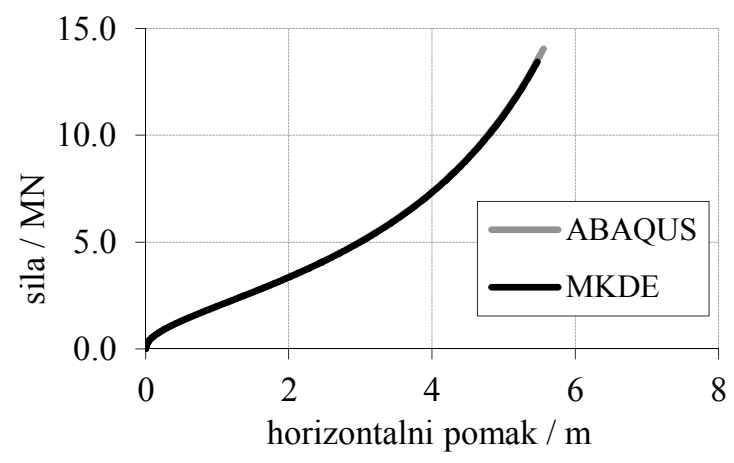

(b)

Crtež 4.18 Usporedba pomaka na slobodnom kraju konzole (a) sila-vertikalni pomak, (b) sila-horizontalni pomak.

Na crtežu je vidljivo kako su numerička rješenja usuglašena, odnosno kako je predloženi model sposoban predvidjeti ponašanje konstrukcije i uslijed konačnih pomaka i konačnih rotacija.

\subsubsection{Prosta greda opterećena centričnim tlakom}

Prosta greda, čije geometrijske i materijalne karakteristike odgovaraju onima usvojenima u primjeru 4.2.1, odabrana je u svrhu validacije gubitka stabilnosti predloženog numeričkog modela. 
Greda je podložena monotono rastućem tlačnom opterećenju na svom desnom kraju, izazvanom preko brzine $v$, kako je prikazano na crtežu 4.19. Usvojena brzina iznosi

$$
v=0.25 \cdot 10^{-7} b^{3} t(\mathrm{~m} / \mathrm{s})
$$

gdje $b$ predstavlja debljinu grede, dok $t$ predstavlja vrijeme u sekundama.

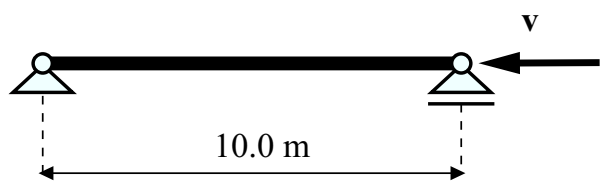

Crtež 4.19 Prosta greda pod opterećenjem od brzine

Kada sila izazvana horizontalnim pomakom uslijed brzine $v$ dosegne kritičnu vrijednost, sustav postaje nestabilan i dolazi do pojave izvijanja. Rezultati dobiveni predloženim numeričkim modelom prikazani su na crtežu 4.20. Da bi se unio neki oblik imperfekcije u sustav, pretpostavljena je zanemarujuće mala vrijednost gravitacije od $g=10^{-10} \mathrm{~m} / \mathrm{s}^{2}$.

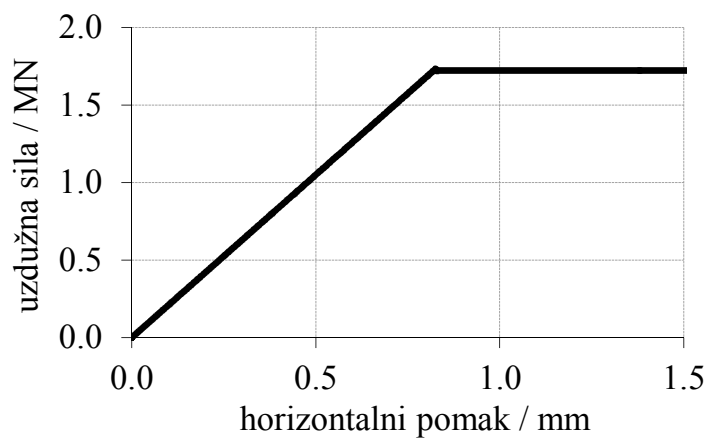

Crtež 4.20 Odnos pomak-uzdužna sila na desnom kraju grede debljine 100mm

Diskretizacija konstrukcije izvršena je pomoću 16 konačnih elemenata. Kritična sila, dobivena iz predloženog modela, uspoređena je sa analitičkim rješenjem [M6], kako je i prikazano u tablici 4.9.

Tablica 4.9 Kritično opterećenje (MN)

\begin{tabular}{|c|c|c|c|c|}
\hline Debljina grede & $\mathbf{2 5} \mathbf{~ m m}$ & $\mathbf{5 0} \mathbf{~} \mathbf{m}$ & $\mathbf{1 0 0} \mathbf{~ m m}$ & $\mathbf{2 0 0} \mathbf{~ m m}$ \\
\hline \hline MKDE $(l=L / 2)$ & 0.02187 & 0.1750 & 1.400 & 11.206 \\
$\operatorname{MKDE}(l=L / 4)$ & 0.02563 & 0.2050 & 1.641 & 13.131 \\
$\operatorname{MKDE}(l=L / 8)$ & 0.02664 & 0.2131 & 1.705 & 13.652 \\
MKDE $(l=L / 16)$ & 0.02690 & 0.2152 & 1.722 & 13.783 \\
\hline Analitički & 0.02698 & 0.2158 & 1.727 & 13.817 \\
\hline
\end{tabular}


Relativna pogreška numeričkog rješenja u usporedbi sa analitičkim rješenjem prikazana je u tablici 4.10. Vidljivo je kako sa povećanjem broja konačnih elemenata numeričko rješenje konvergira ka analitičkom, te se pogreška smanjuje sa $l^{2}$. Također, može se uočiti kako je relativna pogreška istog reda kao i pogreška dobivena u primjeru 4.2.1. Ovaj primjer prikazuje da predloženi numerički model uspješno uzima u obzir pojavu izvijanja, što spada u standardni pristup u MKDE.

Tablica 4.10 Relativna pogreška kritičnog opterećenja u usporedbi sa analitičkim rješenjem (\%)

\begin{tabular}{|c|c|c|c|c|}
\hline Debljina grede & $\mathbf{2 5} \mathbf{~ m m}$ & $\mathbf{5 0} \mathbf{~ m m}$ & $\mathbf{1 0 0} \mathbf{~ m m}$ & $\mathbf{2 0 0} \mathbf{~ m m}$ \\
\hline \hline $\operatorname{MKDE}(l=L / 2)$ & 18.94 & 18.90 & 18.93 & 18.90 \\
$\operatorname{MKDE}(l=L / 4)$ & 5.00 & 5.00 & 4.98 & 4.96 \\
$\operatorname{MKDE}(l=L / 8)$ & 1.26 & 1.25 & 1.27 & 1.19 \\
$\operatorname{MKDE}(l=L / 16)$ & 0.30 & 0.28 & 0.30 & 0.25 \\
\hline
\end{tabular}

\subsubsection{Luk podložen monotono rastućem koncentriranom opterećenju}

Ovaj primjer odabran je u svrhu analize ponašanja konstrukcije nakon dosezanja točke maksimalne nosivosti. Dva luka, čije geometrije su prikazane na crtežu 4.21, podložena su monotono rastućoj koncentriranoj sili u sredini raspona. Karakteristika materijala korištenog u ovom primjeru je $E=210 \mathrm{GPa}$, gustoća $\rho=7850 \mathrm{~kg} / \mathrm{m}^{3}$, dok je za konstantu gravitacije usvojeno $g=10 \mathrm{~m} / \mathrm{s}^{2}$. Širina poprečnog presjeka uzeta je kao $1 \mathrm{~m}$, dok je visina poprečnog presjeka $100 \mathrm{~mm}$.

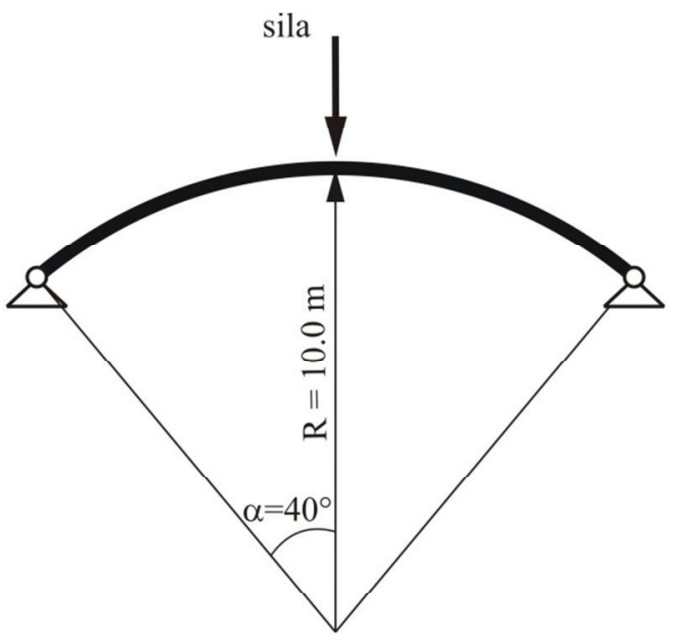

(a)

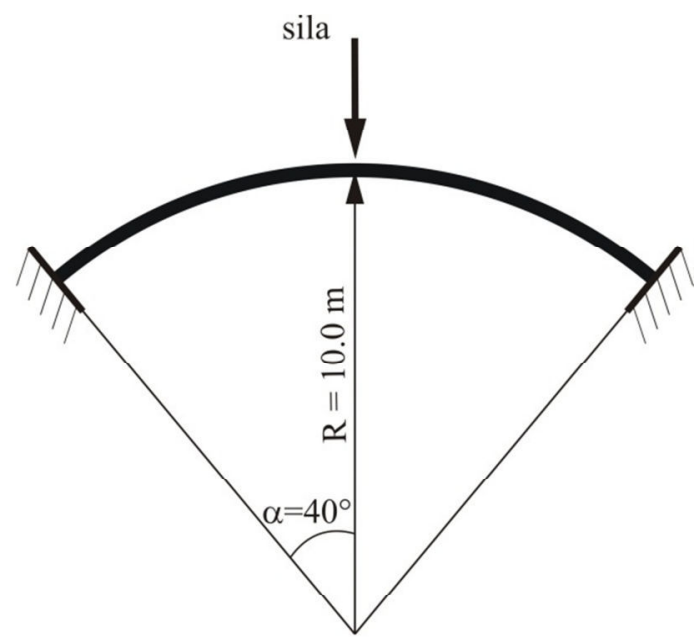

(b)

Crtež 4.21 Luk podložen monotono rastućem koncentriranom opterećenu (a) zglobni luk, (b) upeti luk.

Diskretizacija konstrukcije unutar MKDE modela izvršena je pomoću 128 konačnih elemenata. Krivulja sila-pomak na sredini lukova dobivena predloženim MKDE modelom uspoređena je sa geometrijski nelinearnim rješenjem dobivenim sa ABAQUS-om, koristeći 427 
tročvorna konačna elemenata (crtež 4.22). Sa crteža je vidljivo kako su oba numerička rješenja usuglašena, odnosno kako je predloženi model sposoban predvidjeti kritično i post-kritično ponašanje konstrukcije.

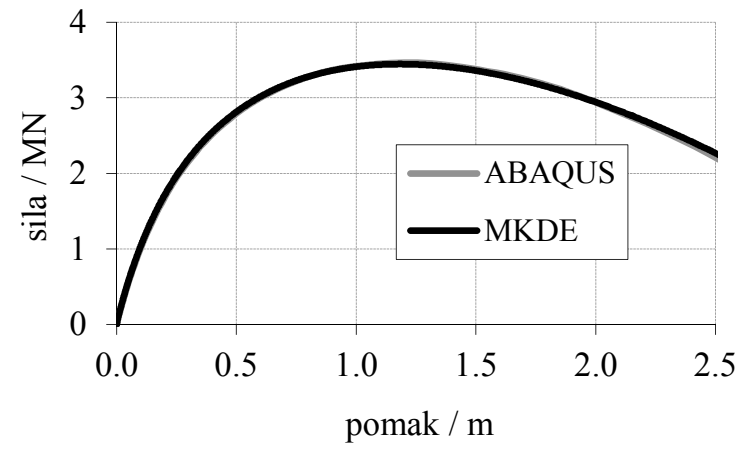

(a)

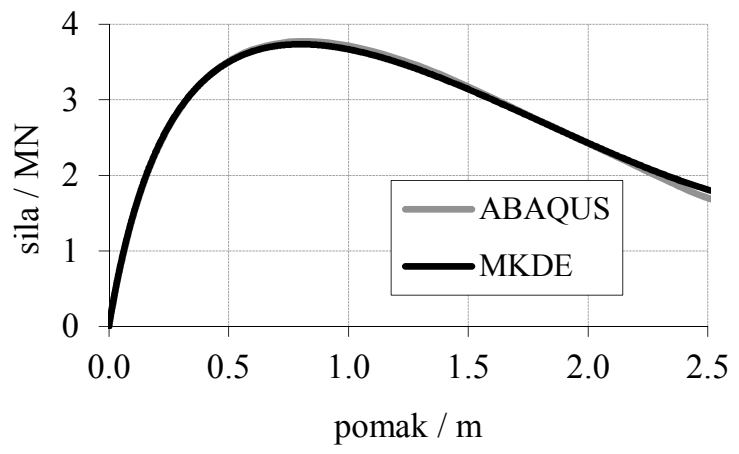

(b)

Crtež 4.22 Usporedba krivulje sila-pomak na sredini luka (a) zglobni luk, (b) upeti luk.

Deformacijski oblik zglobnog i upetog luka, dobiven predloženim MKDE modelom, u trenutku kada središnji progib iznosi 1.0 m i 2.5 m prikazan je na crtežu 4.23.

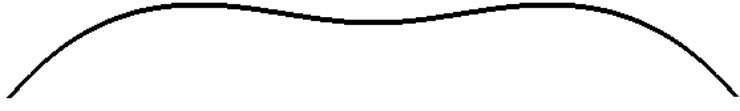

(a)

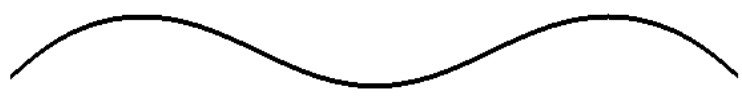

(c)

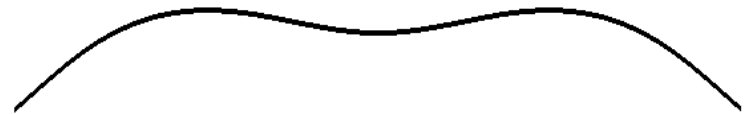

(b)

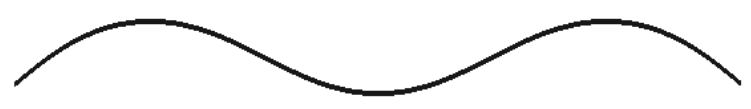

(d)

Crtež 4.23 Deformacijska krivulja luka u trenutku kada središnji progib iznosi $1.0 \mathrm{~m}$ za (a) zglobni luk, (b) upeti luk i $2.5 \mathrm{~m}$ za (c) zglobni luk, (d) upeti luk. 


\section{NUMERIČKI MODELI ZA ANALIZU KONSTRUKCIJA LJUSAKA}

U ovom poglavlju detaljno je prikazan novi razvijeni numerički model za analizu konstrukcija ljusaka u sklopu kombinirane metode konačno-diskretnih elemenata. Kako u okvirima ove metode nema potrebe za sastavljanjem matrica krutosti niti matrice masa, razvoj modela se svodi na računanje čvornih sila na temelju početnih i trenutnih koordinata čvorova konačnih elemenata.

U daljnjem tekstu nalazi se detaljni prikaz konačnog elemenata, diskretizacije i mehanizama nosivosti membranskih i savojnih deformacija kod konstrukcija ljusaka. Prikazane su dvije varijante proračuna savojnih deformacija, od kojih je za daljnju analizi predložena samo jedna varijanta. Da bi se omogućila numerička analiza, ovdje prezentirani modeli implementirani su u kompjuterski program Y-3D [M12]. Razvijeni su algoritmi koji u svakom vremenskom koraku uključuju praćenje stanja naprezanja i deformacija u konačnom elementu, integraciju jednadžbe gibanja u vremenu koja uključuje velike pomake i rotacije te vizualizaciju spomenutih efekata. Također, provedena je i validacija numeričkog modela prikazana na nekoliko jednostavnih primjera koji obuhvaćaju validaciju mehanizama nosivosti membranskih i poprečnih deformacija, te njihove interakcije. 


\subsection{DISKRETIZACIJA LJUSAKA}

Ljuska se u okviru kombinirane metode konačno-diskretnih elemenata promatra kao diskretni element, koji je diskretiziran vlastitom mrežom konačnih elemenata. Diskretizacija je provedena pomoću trokutastih tročvornih elemenata, sa masama koncentriranima u čvorove elemenata, kao što je prikazano na crtežu 5.1.

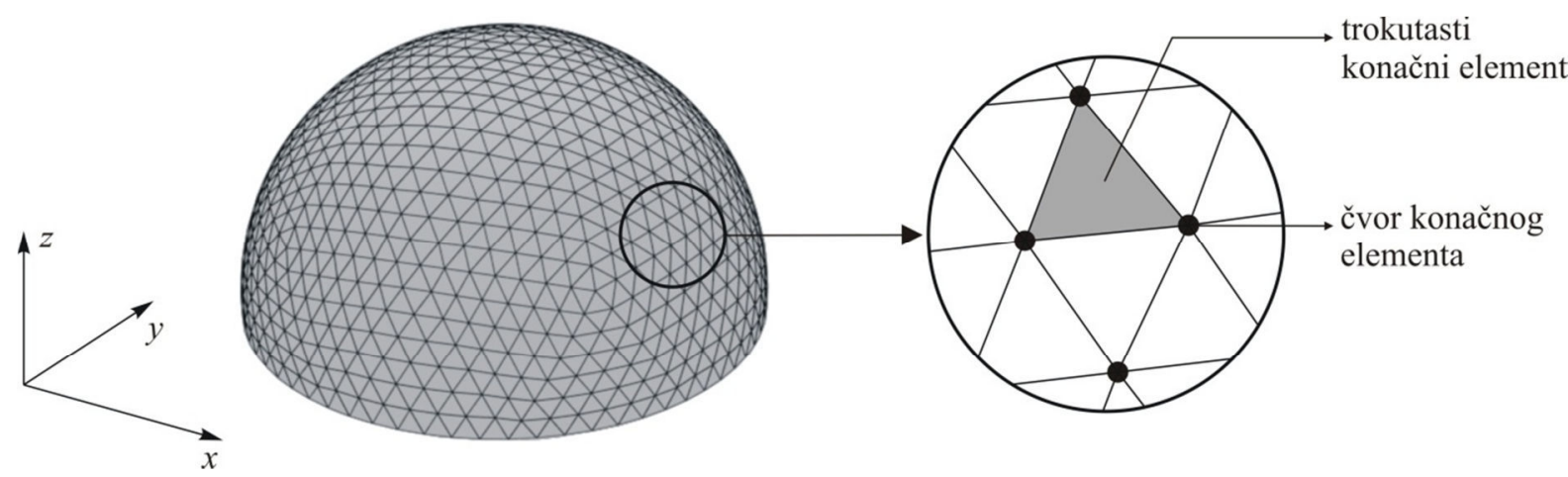

Crtež 5.1 Diskretizacija konstrukcije ljuske

\subsection{MODEL PRIJENOSA MEMBRANSKE KRUTOSTI KOD LJUSAKA}

Poznavanjem početne i trenutne geometrije konačnog elementa moguće je iz pripadne deformacije izračunati membranska naprezanja, odnosno sile u čvorovima u ravnini konačnog elementa. Kao što je već prikazano, geometrija svakog trokuta definirana je pomoću tri pripadajuća čvora, pri čemu je svaki čvor opisan sa pripadnim globalnim kartezijevim koordinatama $(\mathrm{x}, \mathrm{y}, \mathrm{z})$, lokalnim početnim kartezijevim koordinatama $(\bar{x}, \bar{y}, \bar{z})$ i lokalnim trenutnim kartezijevim koordinatama $(\tilde{x}, \tilde{y}, \tilde{z})$, kao što je prikazano na crtežu 5.2.
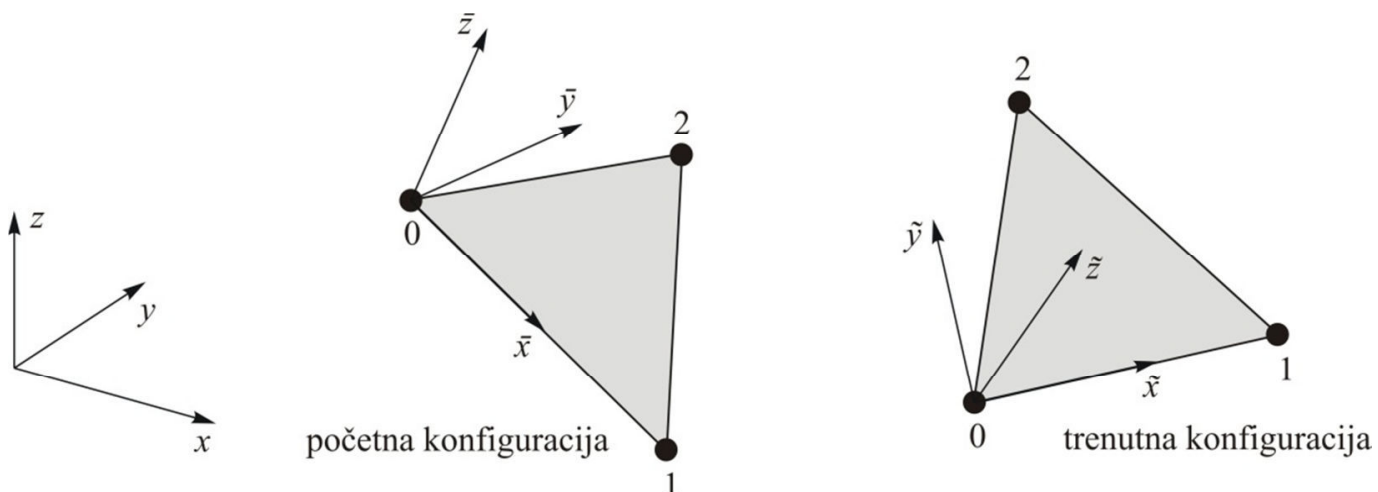

Crtež 5.2 Početna i trenutna konfiguracija tročvornog konačnog elementa

Lokalni rotirani koordinatni sustavi usvojeni su $\mathrm{u}$ svrhu poboljšanja kompjutorske učinkovitosti. Budući da se ravnina konačnog elementa poklapa sa $\mathrm{x}-\mathrm{y}$ ravninom lokalnih 
koordinatnih sustava, konačni element biva prebačen na dvije koordinatne osi. Deformacijski gradijent $\mathbf{F}$ se može prikazati kao (Munjiza, 2004)

$$
\mathbf{F}=\left[\begin{array}{cc}
\tilde{x}_{1}-\tilde{x}_{0} & \tilde{x}_{2}-\tilde{x}_{0} \\
\tilde{y}_{1}-\tilde{y}_{0} & \tilde{y}_{2}-\tilde{y}_{0}
\end{array}\right]\left[\begin{array}{cc}
\bar{x}_{1}-\bar{x}_{0} & \bar{x}_{2}-\bar{x}_{0} \\
\bar{y}_{1}-\bar{y}_{0} & \bar{y}_{2}-\bar{y}_{0}
\end{array}\right]^{-1}
$$

Budući da se ishodište koordinatnog sustava poklapa sa koordinatom prvog čvora konačnog elementa deformacijski gradijent postaje

$$
\mathbf{F}=\left[\begin{array}{ll}
\tilde{x}_{1} & \tilde{x}_{2} \\
\tilde{y}_{1} & \tilde{y}_{2}
\end{array}\right]\left[\begin{array}{ll}
\bar{x}_{1} & \bar{x}_{2} \\
\bar{y}_{1} & \bar{y}_{2}
\end{array}\right]^{-1}
$$

Koristeći deformacijski gradijent, Green-St. Venant deformacijski tenzor može biti prikazan kao (Munjiza, 2004)

$$
\mathbf{E}=1 / 2\left(\mathbf{F F}^{\mathrm{T}}-\mathbf{I}\right)
$$

Uz pomoć Hookovog zakona naprezanja se mogu prikazati kao (Munjiza, 2004)

$$
\mathbf{T}=\frac{E}{1+v} \breve{\mathbf{E}}_{\mathbf{d}}+\frac{E}{1-2 v} \breve{\mathbf{E}}_{\mathbf{s}}+\bar{\mu} \mathbf{D}
$$

gdje je gdje je $E$ modul elastičnosti, $v$ Poissonov koeficijent, $\breve{\mathbf{E}}_{\mathbf{d}}$ deformacija koji se odnosi na promjenu oblika, $\breve{\mathbf{E}}_{\mathbf{s}}$ deformacija koja se odnosi na promjenu volumena, $\bar{\mu}$ koeficijent prigušenja i D tenzor brzine deformiranja.

Uz poznavanje naprezanja u konačnom elementu ekvivalentne čvorne sile mogu biti dobivene integracijom uzduž rubova konačnog elementa

$$
\left[\begin{array}{l}
f_{\widetilde{x}} \\
f_{\widetilde{y}}
\end{array}\right]=\mathbf{T}\left[\begin{array}{l}
n_{\widetilde{x}} \\
n_{\widetilde{y}}
\end{array}\right]
$$

gdje su $n_{\widetilde{x}}$ i $n_{\widetilde{y}}$ komponente geometrijske normale uzduž ruba konačnog elementa. Svakom čvoru pridodaju se sile uslijed naprezanja na polovicama njemu susjednih stranica konačnog elementa. 


\subsection{MODELI PRIJENOSA SAVOJNE KRUTOSTI KOD LJUSAKA}

Kao što je poznato, do aktiviranja savojne krutosti kod konstrukcija ljusaka dolazi uslijed promjene u zakrivljenosti konstrukcije. Shodno tome, da bi se mehanizam savojne krutosti uzeo u obzir potrebno poznavati vrijednost promjene zakrivljenosti na geometriji konstrukcije. U daljnjem tekstu biti će prikazana dva razvijena modela prijenosa savojne krutosti, ovisno o načinu računanja zakrivljenosti konstrukcije.

\subsubsection{Model I}

Model I nastao je kao ideja poopćavanja proračuna lukova (točka 4.1) sa linijskih na plošne zakrivljene konstrukcije. Analogno izrazu (4.4) promatrala se promjena u kutu između dva susjedna konačna elementa, kako je prikazano na crtežu 5.3.

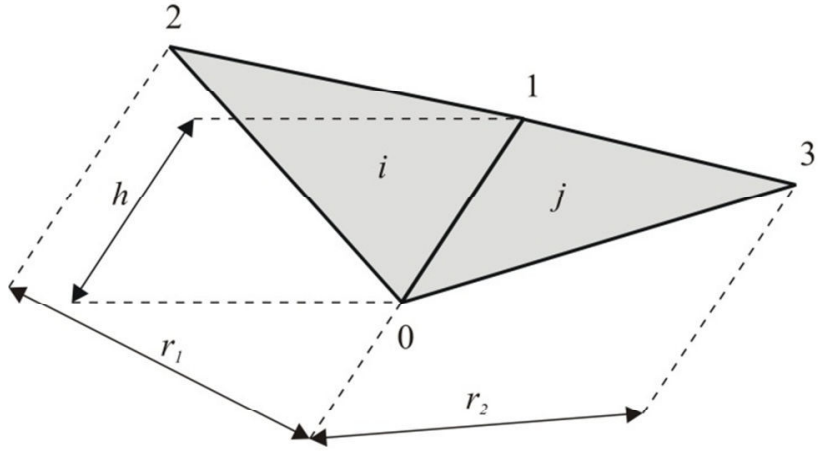

(a)

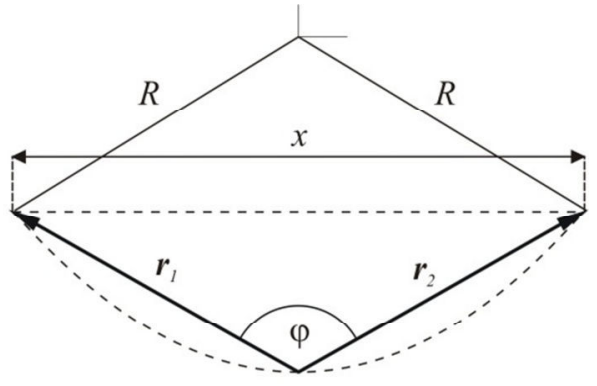

(b)

Crtež 5.3 Dva susjedna konačna elementa (a) geometrija (b) kut između elemenata

Uzimajući u obzir matematički izraz za zakrivljenost triju točaka, početna zakrivljenost susjednih konačnih elemenata može se pisati kao

$$
\kappa_{i}=2 \frac{\sin \varphi_{i}}{x_{i}}
$$

gdje $\varphi_{i}$ predstavlja početni kut između konačnih elemenata, dok $x_{i}$ predstavlja početnu udaljenost, kao što je prikazano na crtežu 5.3. Analogno, trenutna zakrivljenost dobije se kao

$$
\kappa_{c}=2 \frac{\sin \varphi_{c}}{x_{c}}
$$


gdje $\varphi_{c}$ predstavlja početni kut između konačnih elemenata, dok $x_{c}$ predstavlja početnu udaljenost, kao što je prikazano na crtežu 5.3. Promjena zakrivljenosti između dva konačna elementa $\kappa$ može se pisati kao

$$
\kappa=\kappa_{c}-\kappa_{i}
$$

Savojni moment može biti izračunat koristeći konstitutivni zakon, kao što je prikazano na crtežu 5.4. Za linearno elastični materijal savojni moment se može pisati kao (Ventsel, i dr., 2001)

$$
m=\mathrm{I}\left(\kappa+v \kappa_{0}\right)+\left(\dot{\kappa}+v \dot{\kappa}_{0}\right) \mu
$$

gdje $\kappa_{0}$ predstavlja srednju vrijednost promjene zakrivljenosti u smjeru okomito na $\mathbf{r}_{1}$ ili $\mathbf{r}_{2}, \dot{\kappa}$ predstavlja brzinu promjene zakrivljenosti, $\dot{\kappa}_{0}$ predstavlja brzinu promjene zakrivljenosti u smjeru okomitom na $\mathbf{r}_{1}$ ili $\mathbf{r}_{2}, \mu$ predstavlja koeficijent prigušenja, dok $I$ predstavlja dobro poznati izraz za savojnu krutost

$$
I=\frac{E b^{3}}{12\left(1-v^{2}\right)}
$$

gdje je $b$ debljina ljuske.

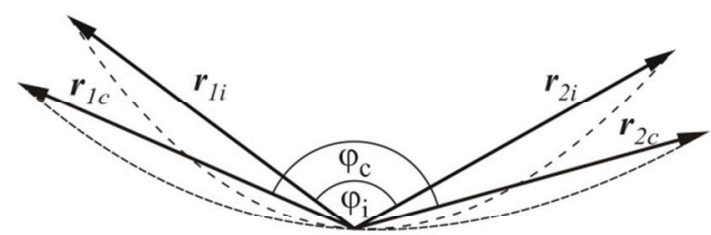

(a)

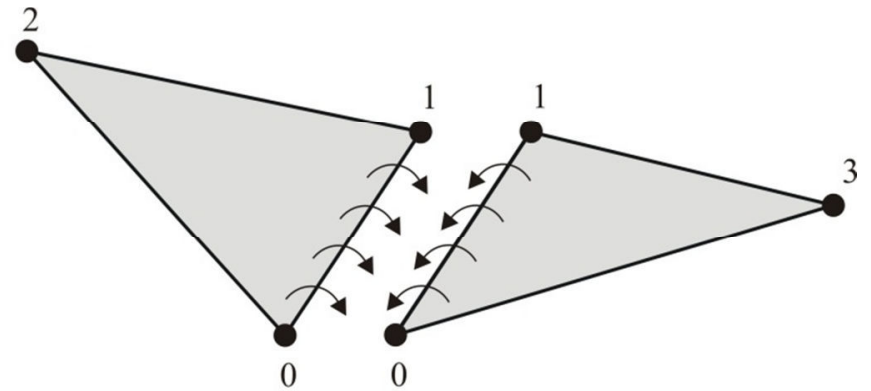

(b)

Crtež 5.4 (a) Početni i trenutni kut između konačnih elemenata (b) Savojni moment

Moment se dalje proračunava $\mathrm{u}$ ekvivalentne čvorne sile f, koje su okomite na ravninu predmetnog konačnog elementa, kao što je prikazano na crtežu 5.5, sa

$$
f_{2}=\frac{m h}{r_{1 c}}, \quad f_{3}=\frac{m h}{r_{2 c}}
$$

gdje je $h$ duljina kontakta između susjednih konačnih elemenata. 


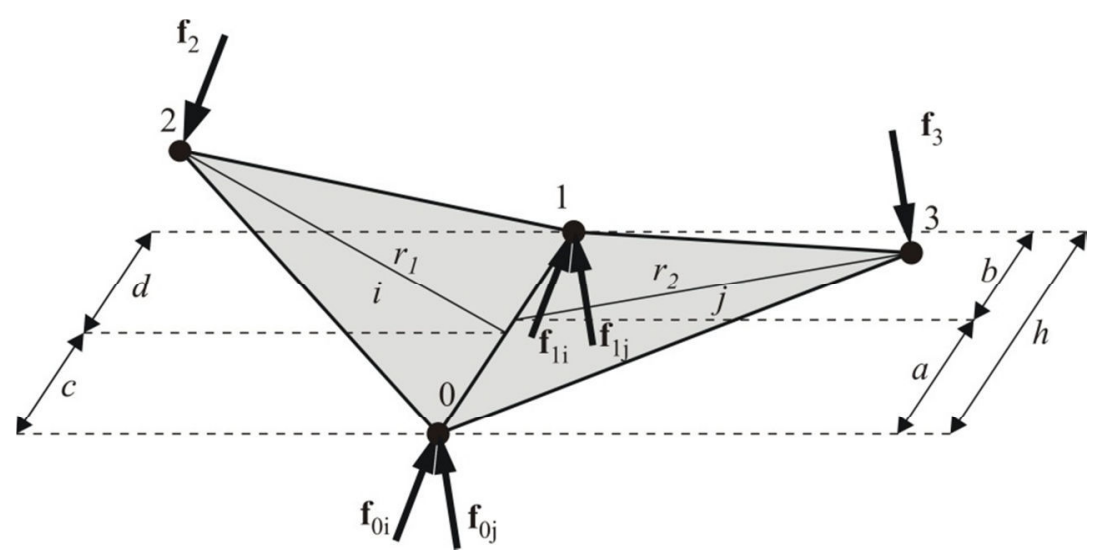

Crtež 5.5 Savojni moment predstavljen sa ekvivalentnim čvornim silama

Sile koje djeluju na pripadajuće čvorove 0 i 1 (crtež 5.5) mogu se odrediti kao

$$
\begin{aligned}
& f_{0 i}=f_{2} \frac{d}{h}, f_{0 j}=f_{3} \frac{b}{h} \\
& f_{1 i}=f_{2} \frac{c}{h}, f_{1 j}=f_{3} \frac{a}{h}
\end{aligned}
$$

Ekvivalentne čvorne sile se dalje dodaju globalnom vektoru čvornih sila. Proceduru prikazanu u ovom poglavlju potrebno je provesti za sve tri stranice konačnog elementa, i to za svaki konačni element.

\subsubsection{Model II}

Da bi se izračunala vrijednost zakrivljenosti na konačnom elementu, konačni element je promatran zajedno sa susjednim čvorovima, kao što je prikazano na crtežu 5.6.
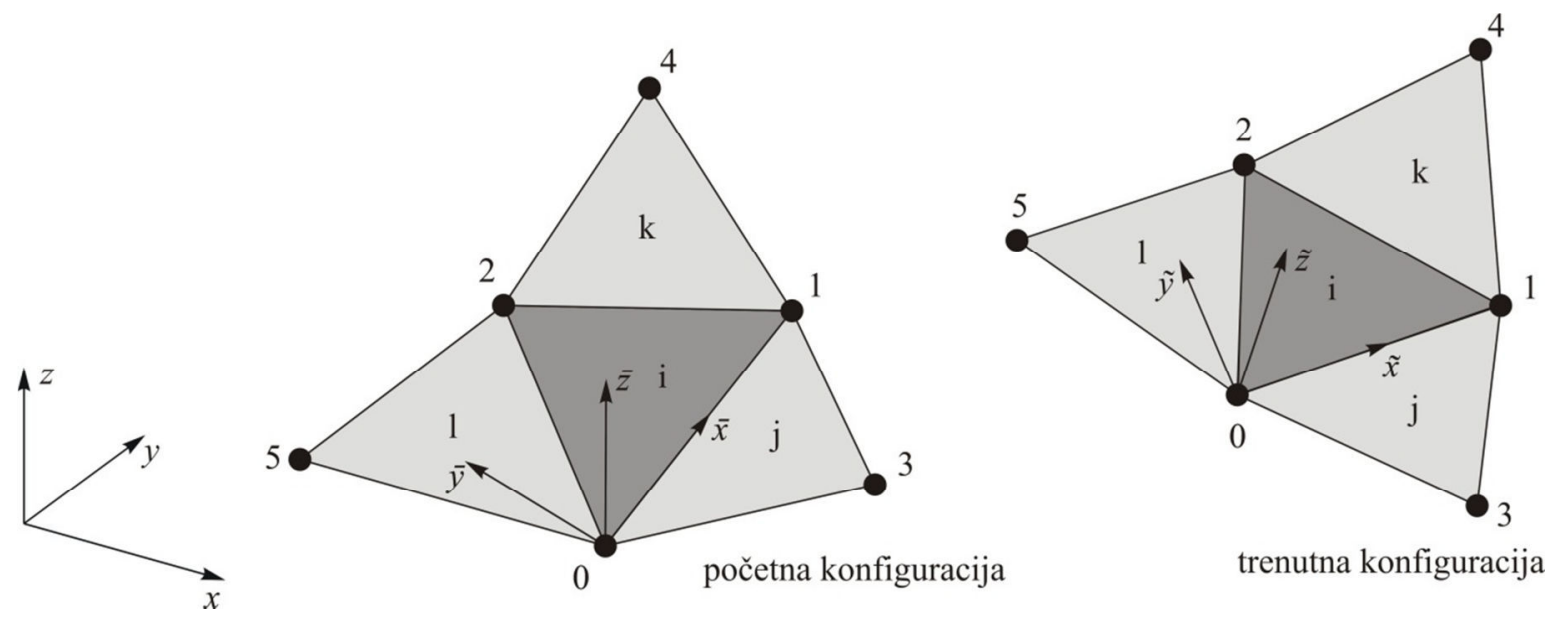

Crtež 5.6 Početna i trenutna konfiguracija konačnog elementa $i$ sa susjednim elementima $j, k$ i $l$ 
Zbog pojednostavljenja proračuna, usvojeni su lokalni koordinatni sustavi također prikazani na crtežu 5.6. Na temelju poznavanja koordinata navedenih čvorova, definiran je polinom drugog stupnja unutar lokalnog koordinatnog sustava na početnoj konfiguraciji (geometriji)

$$
\bar{z}=\bar{\alpha}_{1}+\bar{\alpha}_{2} \bar{x}+\bar{\alpha}_{3} \bar{y}+\bar{\alpha}_{4} \overline{x y}+\bar{\alpha}_{5} \bar{x}^{2}+\bar{\alpha}_{6} \bar{y}^{2}
$$

i na trenutnoj konfiguraciji (geometriji)

$$
\widetilde{z}=\widetilde{\alpha}_{1}+\widetilde{\alpha}_{2} \tilde{x}+\widetilde{\alpha}_{3} \tilde{y}+\widetilde{\alpha}_{4} \tilde{x} \tilde{y}+\widetilde{\alpha}_{5} \tilde{x}^{2}+\tilde{\alpha}_{6} \tilde{y}^{2}
$$

Iz toga proizlaze pripadajuće zakrivljenosti za konačni element $i$, na početnoj konfiguraciji

$$
\bar{\kappa}_{\bar{x} i}=2 \bar{\alpha}_{5}, \quad \bar{\kappa}_{\bar{y} i}=2 \bar{\alpha}_{6}, \quad \bar{\kappa}_{\overline{x y} i}=\bar{\alpha}_{4}
$$

i na trenutnoj konfiguraciji

$$
\widetilde{\kappa}_{\widetilde{\mathrm{x}} \mathrm{i}}=2 \widetilde{\alpha}_{5}, \quad \widetilde{\kappa}_{\tilde{\mathrm{y}} \mathrm{i}}=2 \widetilde{\alpha}_{6}, \quad \widetilde{\kappa}_{\widetilde{\mathrm{x}} \mathrm{i} \mathrm{i}}=\widetilde{\alpha}_{4}
$$

Promjena u zakrivljenosti može biti dobivena oduzimanjem izraza (5.17) od (5.16), odnosno

$$
\kappa_{\widetilde{x} i}=\widetilde{\kappa}_{\widetilde{x} i}-\bar{\kappa}_{\bar{x} i}, \quad \kappa_{\tilde{y} i}=\widetilde{\kappa}_{\tilde{y} i}-\bar{\kappa}_{\bar{y} i}, \quad \kappa_{\widetilde{x} \tilde{y} i}=\widetilde{\kappa}_{\widetilde{x} \tilde{y} i}-\bar{\kappa}_{\overline{x y} i}
$$

Nakon određene promjene u zakrivljenosti, savojni i torzijski momenti za linearno elastični materijal mogu biti lako određeni [V1]

$$
\begin{aligned}
& m_{\widetilde{x} i}=\mathrm{I}\left(\kappa_{\widetilde{x} i}+v \kappa_{\widetilde{y} i}\right)+\left(\dot{\kappa}_{\widetilde{x} i}+v \dot{\kappa}_{\tilde{y} i}\right) \mu \\
& m_{\widetilde{y} i}=\mathrm{I}\left(\kappa_{\tilde{y} i}+v \kappa_{\widetilde{x} i}\right)+\left(\dot{\kappa}_{\tilde{y} i}+v \dot{\kappa}_{\widetilde{x} i}\right) \mu \\
& m_{\widetilde{x} \tilde{y} i}=\mathrm{I}(1-v) \kappa_{\widetilde{x} \tilde{y} i}+(1-v) \dot{\kappa}_{\widetilde{x} \tilde{y} i} \mu
\end{aligned}
$$

gdje $\kappa_{\widetilde{x} i}, \kappa_{\tilde{y} i}$ i $\kappa_{\widetilde{x} \tilde{}}$ predstavljaju brzinu promjene zakrivljenosti, a $\mu$ predstavlja koeficijent prigušenja. Savojna krutost kod ljusaka određena je kao

$$
I=\frac{E b^{3}}{12\left(1-v^{2}\right)}
$$

gdje je $b$ debljina ljuske. Izrazima (5.19), (5.20) i (5.21) određen je savojni moment uzduž odgovarajuće stranice konačnog elementa $i$ 


$$
m_{n i}=m_{\widetilde{x} i} n_{\widetilde{x} i}+m_{\widetilde{y} i} n_{\widetilde{y} i}+2 m_{\widetilde{x} \tilde{y} i} n_{\widetilde{x} i} n_{\widetilde{y} i}
$$

te pripadajući torzijski moment

$$
m_{t i}=m_{\tilde{x} \tilde{y} i}\left(n^{2} \tilde{x} i-n^{2} \tilde{y} i\right)-\left(m_{\tilde{x} i}-m_{\tilde{y} i}\right) n_{\tilde{x} i} n_{\tilde{y} i}
$$

gdje su $n_{\widetilde{x} i}$ i $n_{\widetilde{y} i}$ komponente geometrijske normale uzduž odgovarajućeg ruba konačnog elementa $i$ u lokalnom koordinatnom sustavu (crtež 5.7). Izrazi (5.14) - (5.24) ponovljeni su za konačni element $j$, što daje savojni moment $m_{n j}$ i torzioni moment $m_{t j}$. Moment uzduž pripadajuće stranice konačnog elementa dobije se kao

$$
\begin{gathered}
m_{n}=0.50\left(m_{n i}+m_{n j}\right) \\
m_{t}=0.50\left(m_{t i}+m_{t j}\right)
\end{gathered}
$$

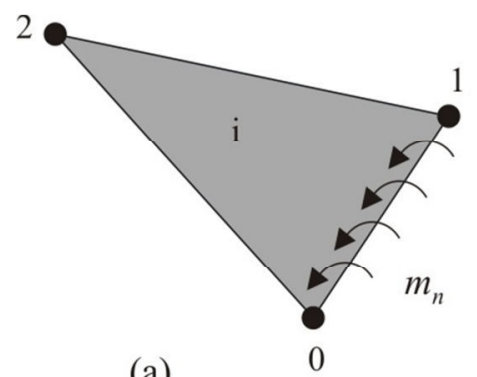

(a)

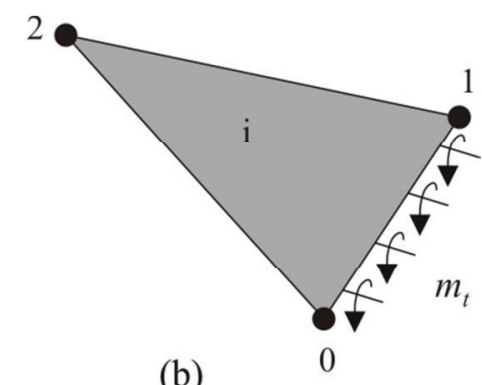

(b)

Crtež 5.7 Moment uzduž stranice konačnog elementa (a) savojni moment (b) torzijski moment

Savojni moment $m_{n}$ i torzijski moment $m_{t}$ nadalje se raspoređuju u ekvivalentne čvorne sile f, okomite na ravninu konačnog elementa, kao što je prikazano na crtežu 5.8. Sile u čvorovima 0,1 i 2 uslijed savojnog momenta iznose

$$
\mathrm{f}_{\mathrm{b} 2}=\frac{\mathrm{m}_{\mathrm{n}} \mathrm{h}}{\mathrm{d}}, \quad \mathrm{f}_{\mathrm{b} 0}=\mathrm{f}_{\mathrm{b} 2} \frac{\mathrm{b}}{\mathrm{h}}, \quad \mathrm{f}_{\mathrm{b} 1}=\mathrm{f}_{\mathrm{b} 2} \frac{\mathrm{a}}{\mathrm{h}}
$$

a uslijed torzijskog momenta iznose

$$
f_{t 0}=f_{t 1}=\frac{m_{t} h}{h}=m_{t}
$$




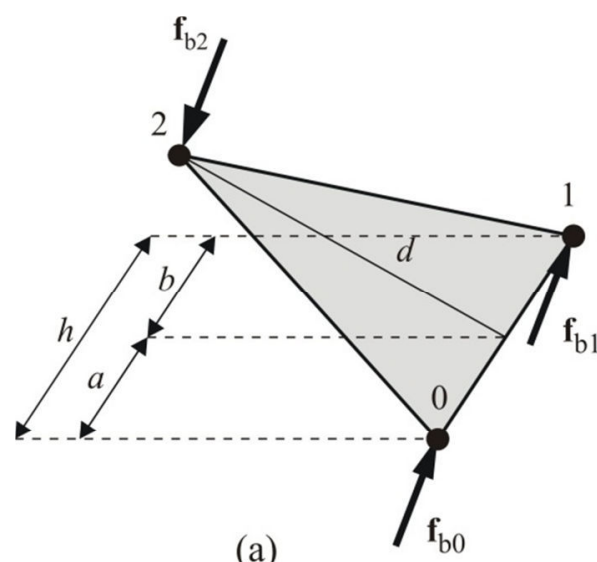

(a)

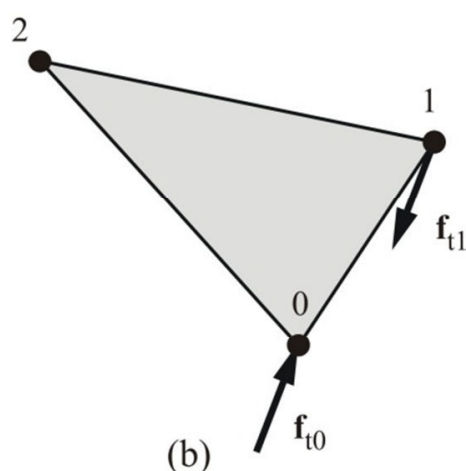

(b)

Crtež 5.8 Ekvivalentne čvorne sile uslijed (a) savojnog momenta (b) torzijskog momenta

Procedura prikazana $\mathrm{u}$ ovom poglavlju ponavlja se za svaki konačni element, sa određivanjem ekvivalentnih čvornih sile kod svake stranice konačnog elementa. Ekvivalentne sile dodaju se globalnom vektoru čvornih sila.

Za slučaj rubnih konačnih elemenata potrebno je nadomjestiti nedostatak jednog ili dva susjedna čvora potrebna za određivanje izraza (5.14) i (5.15). Kod zglobnih i slobodnih rubnih uvjeta čvor koji nedostaje zamjenjuje se prvim najbližim čvorom, kako je prikazano na crtežu 5.9., a daljnji postupak određivanja zakrivljenosti jednak je za početnu i trenutnu konfiguraciju kako je to prethodno opisano.

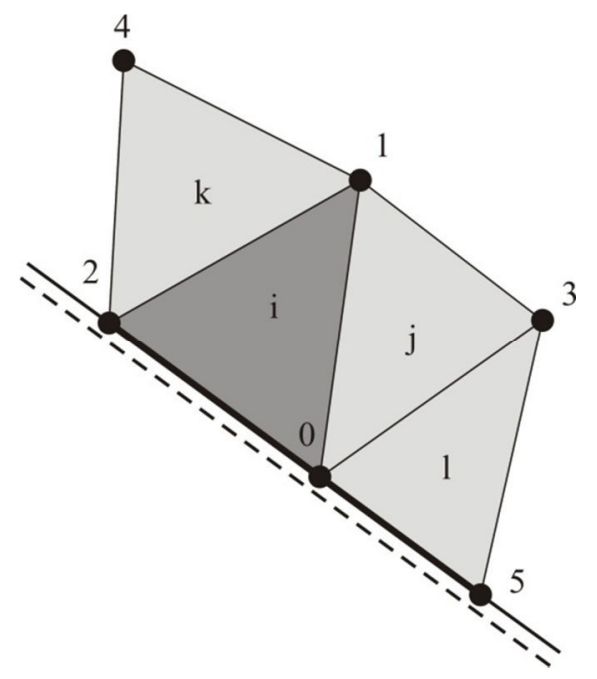

Crtež 5.9 Čvorovi korišteni pri određivanju zakrivljenosti konačnog elementa $i$, za slučaj zglobnih rubnih

$$
\text { uvjeta }
$$

Upeti rubni uvjet može se uzeti u obzir preko plohe koja prolazi kroz čvorove promatranog trokutnog konačnog elementa i čvorove njemu susjednih konačnih elemenata, te čija tangenta okomito na upeti rub odgovara tangenti na konstrukciju. 
U aktualnoj implementaciji to je postignuto pojednostavljenim postupkom uvodeći fiktivne čvorove koji zamjenjuju čvorove koji nedostaju (crtež 5.10). Iz crteža je vidljivo da je postupak određivanja zakrivljenosti na upetome rubu ekvivalentan onome opisanom u poglavlju 4. Fiktivni čvorovi imaju fiksne koordinate u početnoj i trenutnoj konfiguraciji, a nalaze se na plohi koja prolazi kroz čvorove promatranog trokutnog konačnog elementa i njemu susjednih konačnih elemenata te čija se tangenta okomito na upeti rub poklapa sa tangentom na konstrukciju.
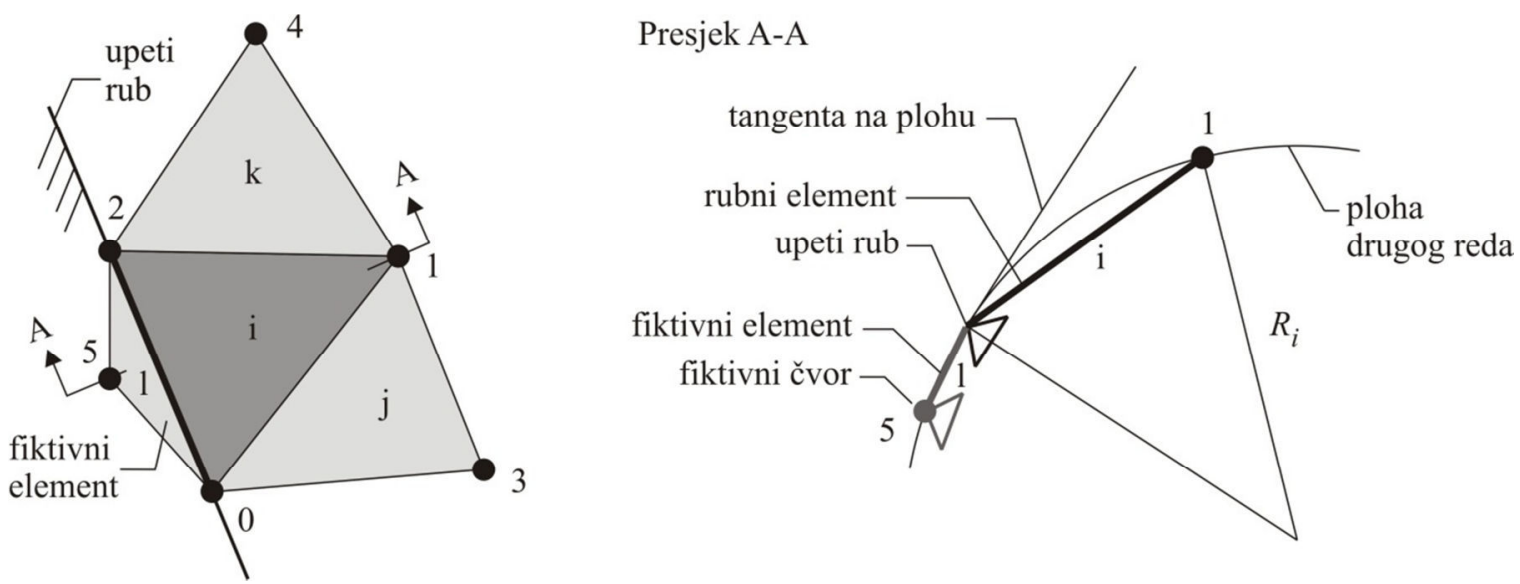

Crtež 5.10 Određivanje zakrivljenosti konačnog elementa $i$, u početnoj konfiguraciji za slučaj upetih rubnih uvjeta

$\mathrm{Na}$ ovaj način zakrivljenost na rubnom elementu u početnoj konfiguraciji je egzaktno određena, međutim u trenutnoj konfiguraciji dolazi do određenih odstupanja budući da se tangenta na plohu okomito na rubnu stranicu i tangenta na konstrukciju ne poklapaju (crtež 5.11). Što je fiktivni čvor bliži upetome rubu, to tangenta na plohu teži tangenti na konstrukciju. Može se pokazati da ako je duljina elementa $l$ više od tisuću puta manja od elementa i to je odstupanje manje od $0.01 \%$.
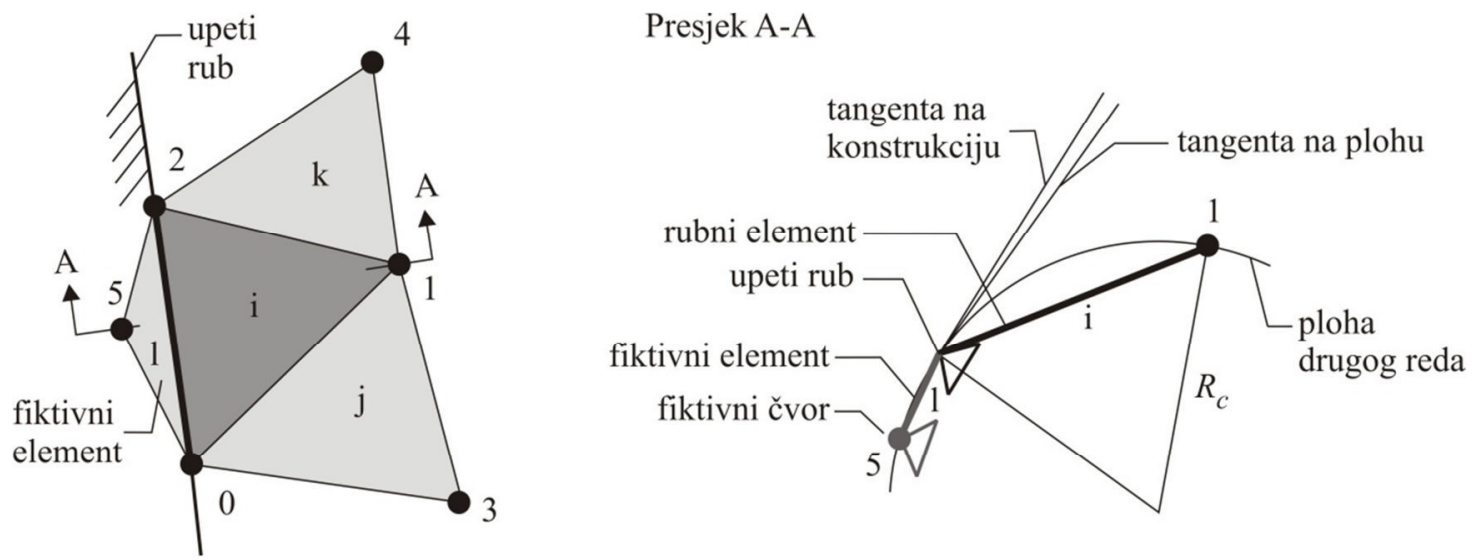

Crtež 5.11 Određivanje zakrivljenosti konačnog elementa $i$, u trenutnoj konfiguraciji za slučaj upetih rubnih uvjeta 


\subsection{VERIFIKACIJA NUMERIČKOG MODELA - MODEL I}

Budući da je model I pokazao nezadovoljavajuće rezultate, u nastavku će se prikazati primjeri koji će prikazati manjkavost ovog modela.

\subsubsection{Slobodno oslonjena kvadratna ploča pod jednoosnim savijanjem - model I}

Kvadratna ploča, kao što je prikazano na crtežu 5.12, odabrana je u svrhu verificiranja savojne krutosti numeričkog modela.

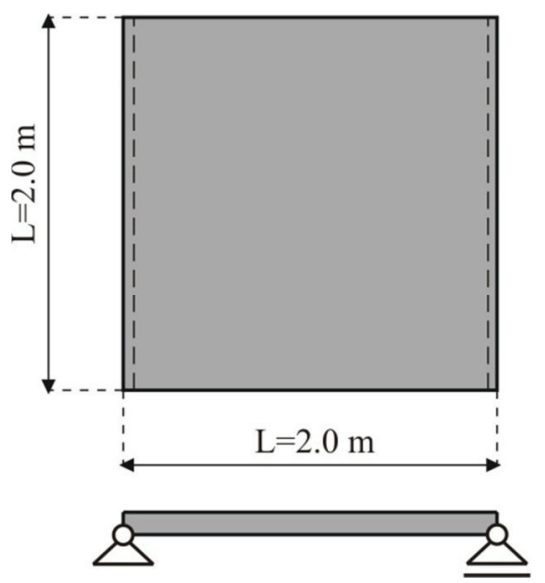

Crtež 5.12 Početna geometrija kvadratne ploče pod jednoosnim savijanjem

Debljina ploče iznosi $0.012 \mathrm{~m}$, modul elastičnosti $E=210 \mathrm{GPa}$, dok je Poissonov koeficijent jednak nuli. Gustoća materijala iznosi to $\rho=7850 \mathrm{~kg} / \mathrm{m}^{3}$, a konstanta gravitacije pretpostavljena je kao $g=10.0 \mathrm{~m} / \mathrm{s}^{2}$. Počevši od idealno ravne geometrije, ploča uslijed vlastite težine i bez djelovanja prigušenja oscilira oko ravnotežnog položaja.

Analiza je provedena za tri mreže konačnih elemenata (F1, F2 i F3), sa diskretizacijama kao što je pokazano na crtežu 5.13. Mreže F1, F2 i F3 sastoje se od 580, 1160 i 2612 trokutnih konačnih elemenata.

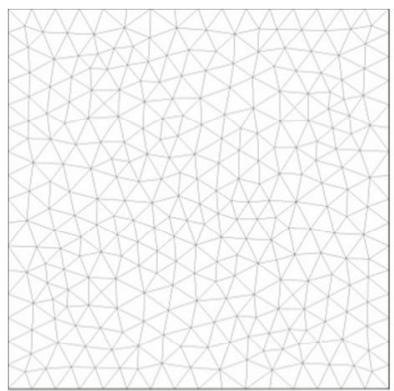

(a)

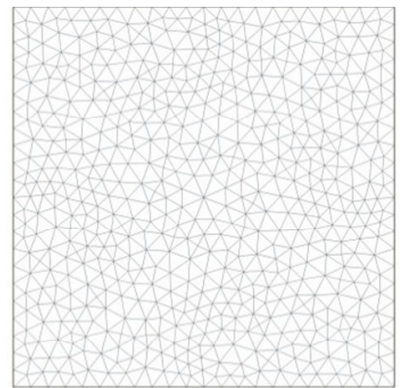

(b)

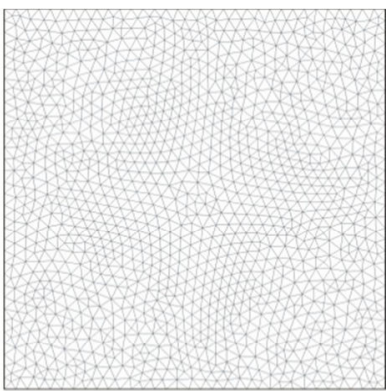

(c)

Crtež 5.13 Diskretizacija kvadratne ploče za model I (a) F1 (b) F2 (c) F3 
Crtež 5.14 pokazuje krivulju pomaka na sredini ploče u vremenu, za tri različite diskretizacije, uspoređenu sa nelinearnim numeričkim rješenjem dobivenim pomoću programskog paketa ABAQUS [S10]. Numeričko rješenje iz ABAQUS-a provedeno je za geometrijski linearnu i nelinearni analizu, koristeći 400 četverostraničnih osamčvornih konačnih elemenata sa šest stupnjeva slobode u čvoru. Linearno rješenje iz ABAQUS-a poklapa se sa analitičkim rješenjem [M6], što implicira da je mreža usvojena u ABAQUS-u dovoljno fina.

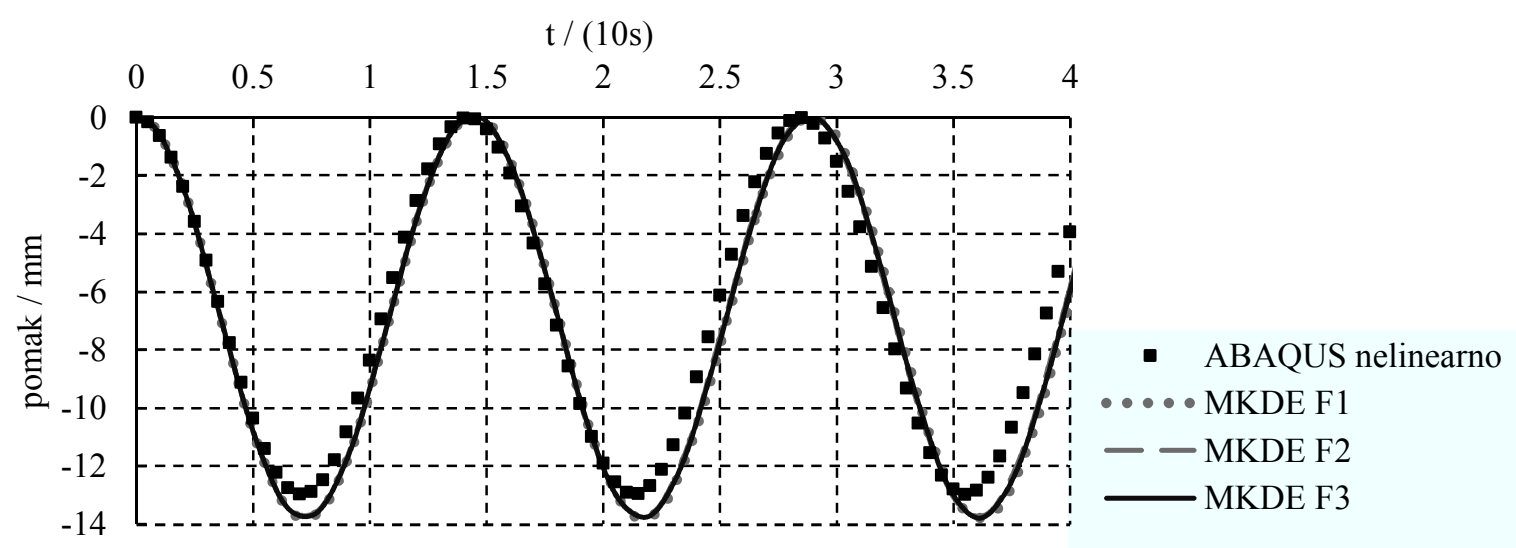

Crtež 5.14 Pomak središta ploče za slobodno osciliranje pod jednoosnim savijanjem - model I

Tablica 5.1 prikazuje vrijednosti maksimalnog pomaka dobivenog iz predstavljenog MKDE modela za tri različite diskretizacije, te njegovu pogrešku u odnosu na nelinearno numeričko rješenje dobiveno pomoću programskog paketa ABAQUS.

Tablica 5.1 Usporedba numeričkog rješenja za jednoosno savijanje - model I

\begin{tabular}{|c|c|c|}
\hline Diskretizacija & Pomak (mm) & Pogreška (\%) \\
\hline \hline F1 & 13.777 & 6.14 \\
\hline F2 & 13.703 & 5.57 \\
\hline F3 & 13.739 & 5.84 \\
\hline
\end{tabular}

Iz crteža 5.1 i tablice 5.1 vidljivo je kako predstavljeni model ne postiže zadovoljavajući opis savojne krutosti ploče pod jednoosnim savijanjem. Proguščenjem mreže konačnih elemenata model se ne približava ka rješenju dobivenom iz ABAQUS-a, i ne bilježi konvergenciju.

\subsubsection{Slobodno oslonjena kvadratna ploča pod dvoosnim savijanjem - model I}

Kvadratna ploča, slobodno oslonjena na sve četiri stranice, odabrana je u svrhu dodatnog analiziranja savojne krutosti numeričkog modela. Dimenzije, diskretizacija i mehaničke karakteristike ploče odgovaraju onima prikazanima u prethodnom primjeru, uz iznimku 
Poissonovog koeficijenta koji iznosi $v=0.3$. Počevši od idealno ravne geometrije, ploča uslijed vlastite težine i bez djelovanja prigušenja oscilira oko ravnotežnog položaja.

Crtež 5.15 pokazuje krivulju pomaka na sredini ploče u vremenu, za tri različite diskretizacije, uspoređenu sa nelinearnim numeričkim rješenjem dobivenim pomoću programskog paketa ABAQUS [S10]. Numeričko rješenje iz ABAQUS-a provedeno je za geometrijski linearnu i nelinearni analizu, koristeći 400 četverostraničnih osamčvornih konačnih elemenata sa šest stupnjeva slobode u čvoru. Linearno rješenje iz ABAQUS-a poklapa se sa analitičkim rješenjem [V1], što implicira da je mreža usvojena u ABAQUS-u dovoljno fina.

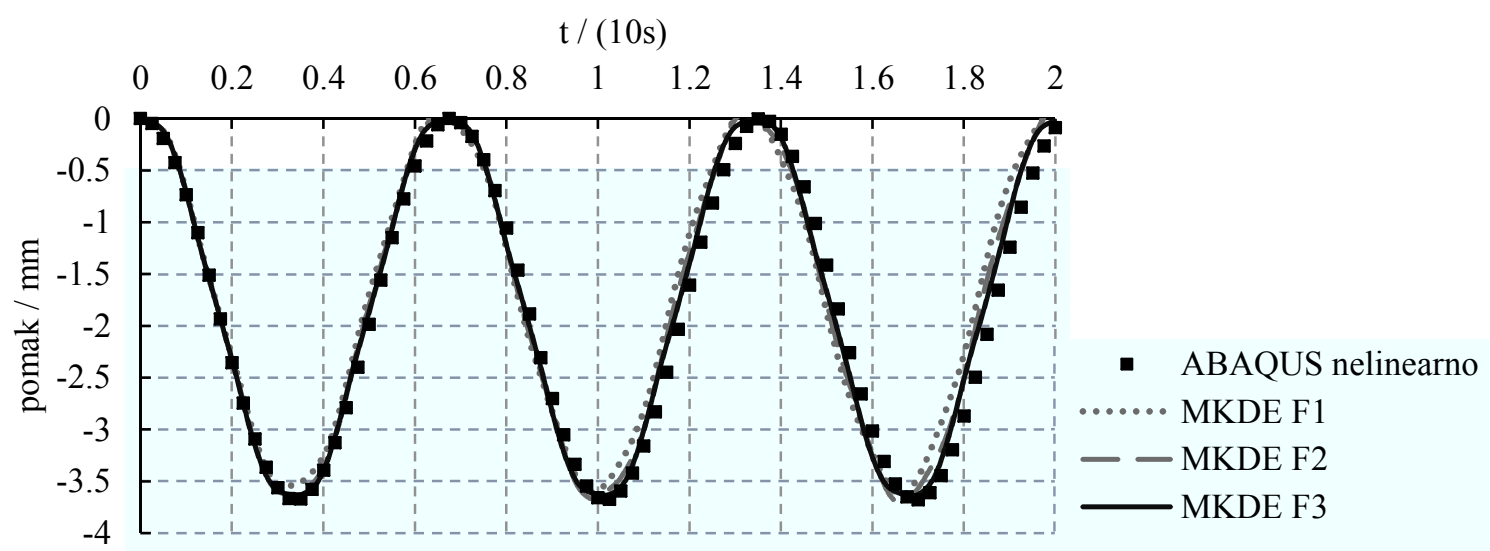

Crtež 5.15 Pomak središta ploče za slobodno osciliranje pod dvoosnim savijanjem - model I

Tablica 5.2 prikazuje vrijednosti maksimalnog pomaka dobivenog iz predstavljenog MKDE modela za tri različite diskretizacije, te njegovu pogrešku u odnosu na nelinearno numeričko rješenje dobiveno pomoću programskog paketa ABAQUS.

Tablica 5.2 Usporedba numeričkog rješenja za dvoosno savijanje - model I

\begin{tabular}{|c|c|c|}
\hline Diskretizacija & Pomak $(\mathrm{mm})$ & Pogreška (\%) \\
\hline \hline F1 & 3.548 & 3.946 \\
\hline F2 & 3.625 & 1.708 \\
\hline F3 & 3.642 & 1.263 \\
\hline
\end{tabular}

Iz tablice je vidljivo kako predstavljeni model sa proguščenjem mreže konačnih elemenata ipak bilježi konvergenciju prema numeričkom rješenju dobivenom pomoću paketa ABAQUS. Međutim, čak i za jako gustu diskretizaciju (F3) bilježi se pogreška od 1.263\%.

\subsubsection{Slobodno oslonjena kružna ploča pod gravitacijskim opterećenjem - model I}

Slobodno oslonjena kružna ploča odabrana je u svrhu dodatnog analiziranja savojne krutosti numeričkog modela. Radijus ploče iznosi $1 \mathrm{~m}$, dok je debljina ploče pretpostavljena kao $0.012 \mathrm{~m}$. 
Mehaničke karakteristike ploče odgovaraju onima korištenima u prethodnom primjeru. Počevši od idealno ravne geometrije, ploča uslijed vlastite težine i bez djelovanja prigušenja oscilira oko ravnotežnog položaja.

Analiza je provedena za tri mreže konačnih elemenata (K1, K2 i K3), sa diskretizacijama kao što je pokazano na crtežu 5.16. Mreže K1, K2 i K3 sastoje se od 394, 834 i 1527 trokutnih konačnih elemenata.

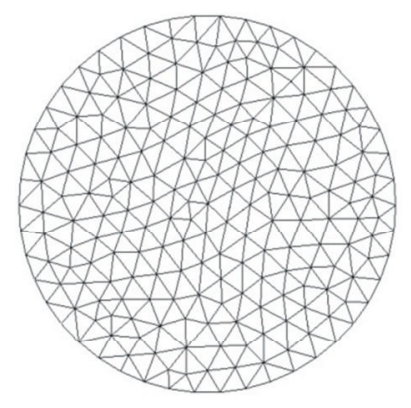

(a)

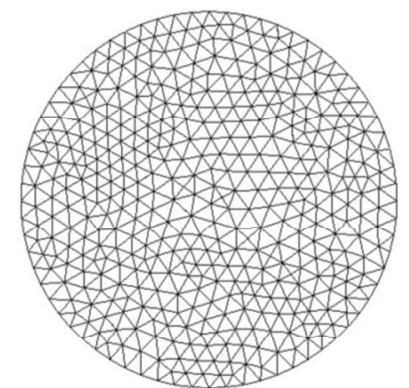

(b)

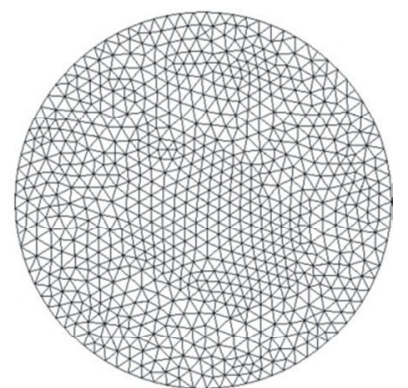

(c)

Crtež 5.16 Diskretizacija kružne ploče za model I (a) K1 (b) K2 (c) K3

Crtež 5.17 pokazuje krivulju pomaka na sredini ploče u vremenu, za tri različite diskretizacije, uspoređenu sa nelinearnim numeričkim rješenjem dobivenim pomoću programskog paketa ABAQUS [S10]. Numeričko rješenje iz ABAQUS-a provedeno je za geometrijski linearnu i nelinearni analizu, koristeći 384 četverostraničnih osamčvornih konačnih elemenata sa šest stupnjeva slobode u čvoru. Linearno rješenje iz ABAQUS-a poklapa se sa analitičkim rješenjem [V1], što implicira da je mreža usvojena u ABAQUS-u dovoljno fina.

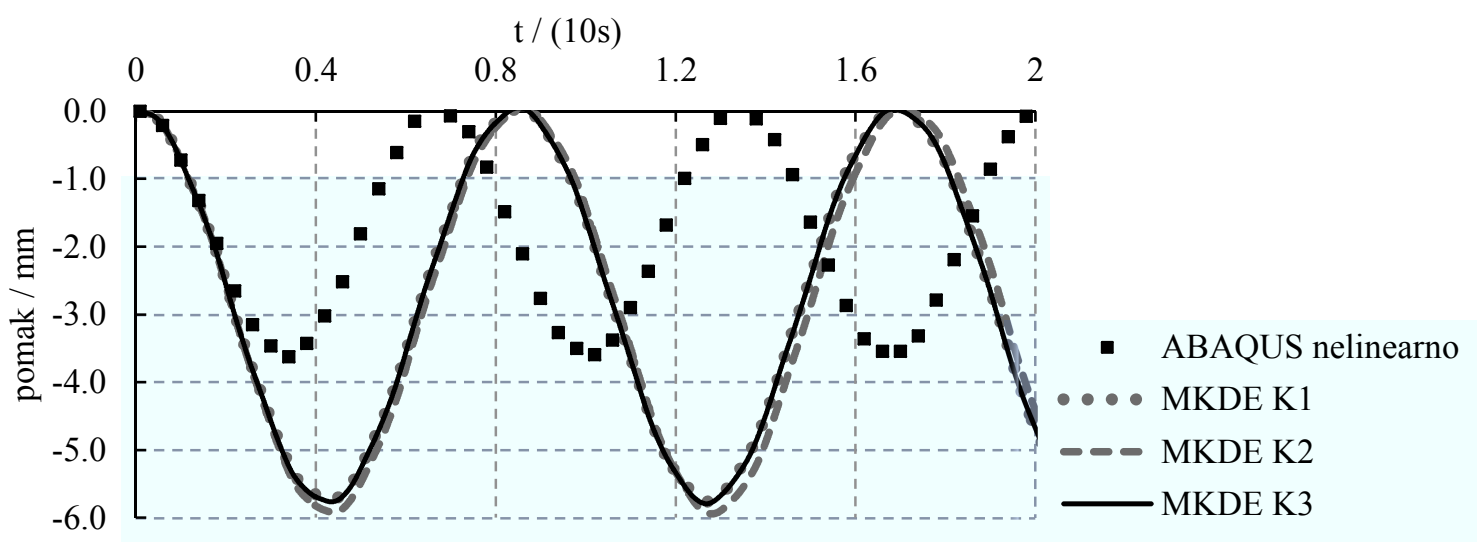

Crtež 5.17 Pomak središta kružne ploče za slobodno osciliranje - model I

Tablica 5.2 prikazuje vrijednosti maksimalnog pomaka dobivenog iz predstavljenog MKDE modela za tri različite diskretizacije te njegovu pogrešku u odnosu na nelinearno numeričko rješenje dobiveno pomoću programskog paketa ABAQUS. 
Tablica 5.3 Usporedba numeričkog rješenja kružne ploče - model I

\begin{tabular}{|c|c|c|}
\hline Diskretizacija & Pomak $(\mathrm{mm})$ & Pogreška (\%) \\
\hline \hline K1 & 5.718 & 59.27 \\
\hline K2 & 5.922 & 64.96 \\
\hline K3 & 5.765 & 60.58 \\
\hline
\end{tabular}

Iz crteža 5.17 i tablice 5.3 vidljivo je kako predstavljeni model bilježi znatna odstupanja pri opisivanju dinamičkog savojnog ponašanja kružne ploče. Proguščenjem mreže konačnih elemenata model se ne približava ka rješenju dobivenom iz ABAQUS-a, i ne bilježi konvergenciju.

\subsection{VERIFIKACIJA NUMERIČKOG MODELA - MODEL II}

Predloženi numerički model implementiran je u open source MKDE paket - Yfdem [M12]. Verifikacija modela izvedena je nizom primjera, uspoređujući dobivene rezultate sa onima očitanima u programskom paketu ABAQUS [S10]. Prikazani su efikasnost i preciznost membranskog i savojnog mehanizma, njihovog kombiniranog djelovanja, analiza stabilnosti, te post-kritično ponašanja konstrukcije.

\subsubsection{Ploča pod vlačnim naprezanjem}

Slobodno oslonjena kvadratna ploča, kao što je prikazano na crtežu 5.18, odabrana je u svrhu verificiranja membranske krutosti numeričkog modela.

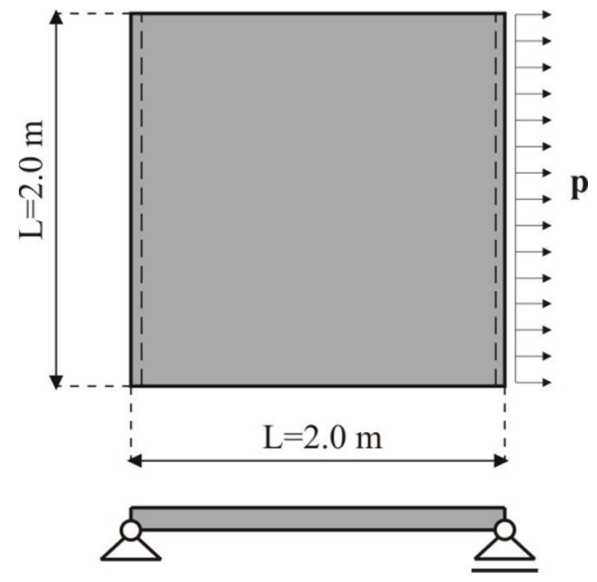

Crtež 5.18 Početna geometrija vlačno opterećene ploče

Ploča je na lijevom rubu fiksirana, dok je desni rub je podložen monotono rastućoj sili

$$
p=300 t\left(k N / m^{\prime}\right)
$$


gdje $t$ predstavlja vrijeme u sekundama. Debljina ploče iznosi $0.012 \mathrm{~m}$, modul elastičnosti $E=210$ $\mathrm{GPa}$, dok je Poissonov koeficijent jednak nuli. Analiza je provedena za tri mreže konačnih elemenata (M1, M2 i M3), sa diskretizacijama kao što je pokazano na crtežu 5.19. Mreže M1, M2 i M3 sastoje se od 36, 160 i 608 trokutnih konačnih elemenata.

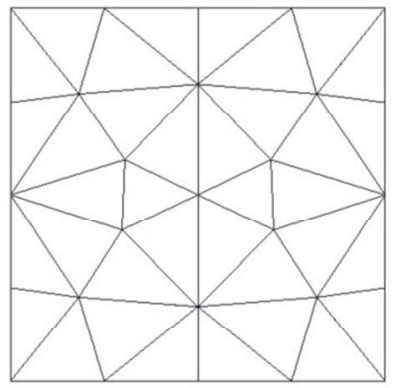

(a)

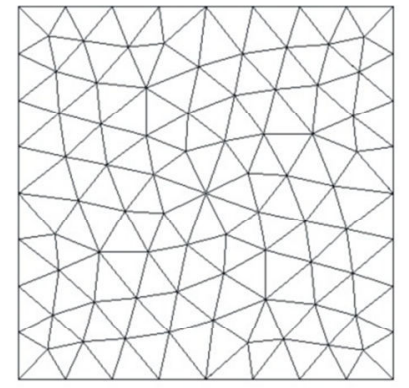

(b)

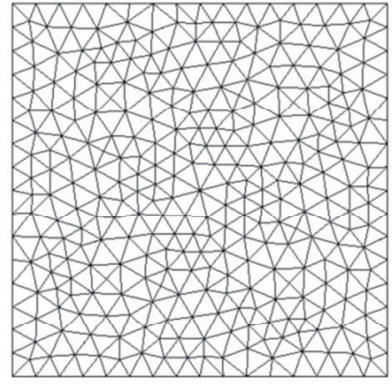

(c)

Crtež 5.19 Diskretizacija kvadratne ploče (a) M1 (b) M2 (c) M3

Usporedba poznatog analitičkog rješenja za pomak na desnom kraju ploče i numeričkog rješenja dobivenog iz predstavljenog modela prikazana je na crtežu 5.20. Vidljivo je kako se za sve tri diskretizacije postiže rješenje jednako analitičkom.

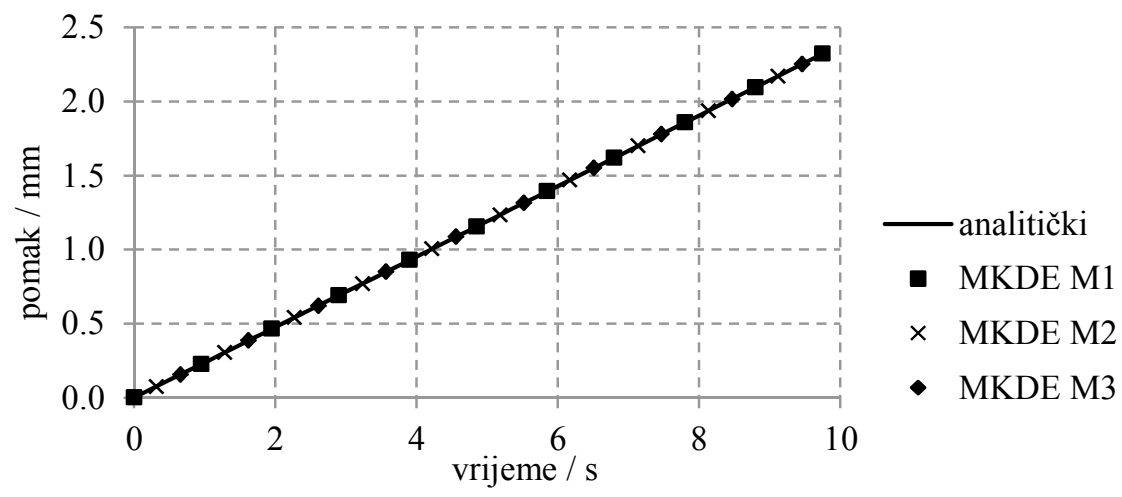

Crtež 5.20 Usporedba analitičkog i numeričkog pomaka na desnom kraju vlačno opterećene ploče

\subsubsection{Slobodno oslonjena kvadratna ploča pod jednoosnim savijanjem}

U svrhu verifikacije mehanizma savojne krutosti kvadratna ploča, sa geometrijom, rubnim uvjetima, materijalnim karakteristikama i diskretizacijom preuzetima iz prethodnog primjera, podložena je gravitacijskom opterećenju. Gustoća materijala iznosi to $\rho=7850 \mathrm{~kg} / \mathrm{m}^{3}$, dok je konstanta gravitacije uzeta kao $g=10.0 \mathrm{~m} / \mathrm{s}^{2}$. Da bi se analizirala eventualna veza greške u progibu na sredini ploče sa debljinom ploče, debljina je varirana kroz sedam slučajeva $(0.5 \mathrm{~mm}, 1 \mathrm{~mm}, 2$ $\mathrm{mm}, 4 \mathrm{~mm}, 8 \mathrm{~mm}, 12 \mathrm{~mm}$ i $16 \mathrm{~mm}$ ). U predmetnoj analizi, ravnotežni progib na sredini ploče 
dobiven je kao rezultat djelovanja prigušenja na slobodne vibracije ploče, počevši od idealno ravne geometrije.

$\mathrm{Na}$ crtežu 5.21 prikazan je pomak središta ploče u vremenu, dobiven predloženim numeričkim modelom uz usvajanje debljine ploče od $b=8 \mathrm{~mm}$ i $b=12 \mathrm{~mm}$ sa koeficijentima prigušenja od $\mu=170 \mathrm{Nms}$ i $\mu=240 \mathrm{Nms}$. Primijenjena mreža konačnih elemenata je M3.

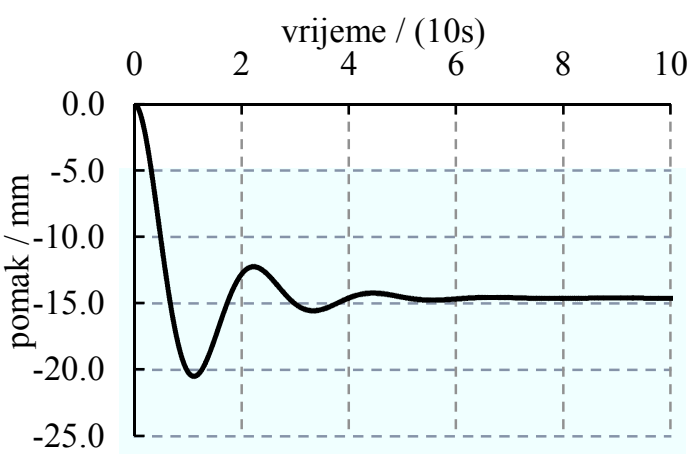

(a)

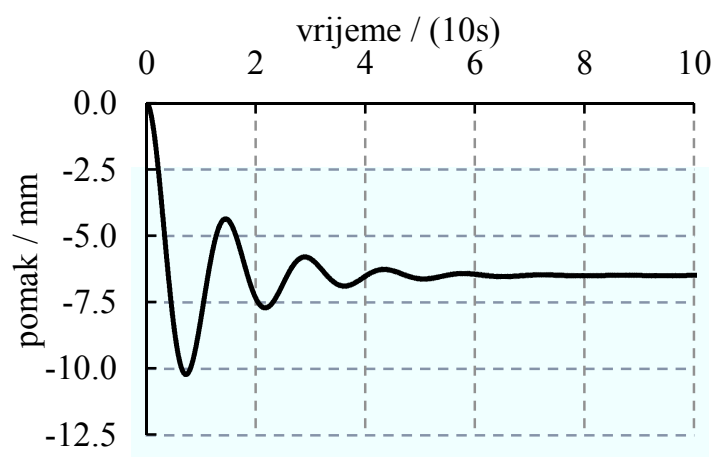

(b)

Crtež 5.21 Pomak središta ploče pod jednoosnim savijanjem za prigušeno osciliranje, za debljinu ploče od (a) $8 \mathrm{~mm}$, (b) $12 \mathrm{~mm}$

Tablica 5.4 prikazuje vrijednosti ravnotežnog pomaka za sedam različitih debljina, dobivene iz predloženog numeričkog modela koristeći tri različite diskretizacije. Također je prikazano i analitičko rješenje ravnotežnog pomaka [M6], te numerička rješenja dobivena koristeći programske pakete ABAQUS [S10] i Scia Engineer [N2]. Za numeričko rješenje korišteno je kod ABAQUS paketa 1600 četverostraničnih osamčvornih konačnih elemenata sa šest stupnjeva slobode u čvoru, dok je kod Scia Engineer paketa korišteno 1600 čevrerostraničnih konačnih elemenata sa šest stupnjeva slobode po čvoru. Za oba paketa pomak je prikazan uzimajući geometrijski linearnu i nelinearnu analizu. Može se uočiti kako numeričko rješenje dobiveno linearnom analizom odgovara analitičkom rješenju, što implicira da su mreže usvojene za ABAQUS i Scia Engineer dovoljno fine.

Tablica 5.4 Usporedba numeričkog i analitičkog rješenja za jednoosno savijanje

\begin{tabular}{|c|c|c|c|c|c|c|c|}
\hline Debljina ploče & $\mathbf{0 . 5} \mathbf{~ m m}$ & $\mathbf{1} \mathbf{~ m m}$ & $\mathbf{2} \mathbf{~ m m}$ & $\mathbf{4} \mathbf{~ m m}$ & $\mathbf{8} \mathbf{~ m m}$ & $\mathbf{1 2} \mathbf{~ m m}$ & $\mathbf{1 6} \mathbf{~ m m}$ \\
\hline \hline MKDE M1 & 725.69 & 525.17 & 214.20 & 56.996 & 14.768 & 6.6305 & 3.7356 \\
MKDE M2 & 760.86 & 553.96 & 221.64 & 58.873 & 14.747 & 6.5602 & 3.6906 \\
MKDE M3 & 763.28 & 554.29 & 219.904 & 58.321 & 14.631 & 6.5029 & 3.6579 \\
\hline Analitički & 3738.1 & 934.52 & 233.63 & 58.408 & 14.602 & 6.4897 & 3.6505 \\
SCIA linearno & 3737.0 & 934.26 & 233.56 & 58.391 & 14.598 & 6.4879 & 3.6496 \\
ABAQUS linearno & 3738.1 & 934.52 & 233.63 & 58.408 & 14.602 & 6.4902 & 3.6509 \\
SCIA nelinearno & 766.19 & 556.44 & 219.33 & 58.106 & 14.584 & 6.4835 & 3.6473 \\
ABAQUS nelinearno & 766.00 & 556.58 & 219.52 & 58.162 & 14.599 & 6.4899 & 3.6509 \\
\hline
\end{tabular}


$\mathrm{Na}$ crtežu 5.22 prikazana je greška numeričkih rezultata dobivenih sa predloženim MKDE modelom u ovisnosti o diskretizaciji i debljini ploče. Rezultati su uspoređivani sa nelinearnim rješenjem dobivenim iz analize ABAQUS-om. Na crtežu 5.22 (a) vidljivo je kako kod finijih mreža debljina ploče nema značajan utjecaj na pogrešku progiba. Na crtežu 5.22 (b) se može uočiti kako sa proguščenjem mreže konačnih elemenata numerički rezultati dobiveni predloženim MKDE modelom konvergiraju ka onima dobivenima sa ABAQUS-om, te postižu izvrsno poklapanje rezultata.

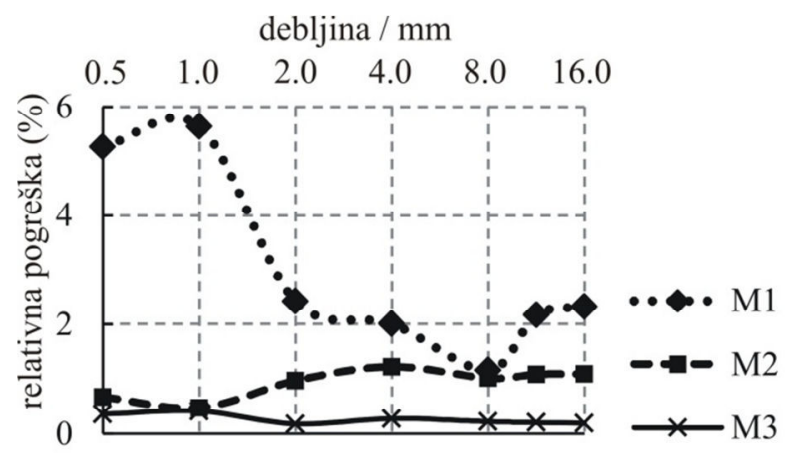

(a)

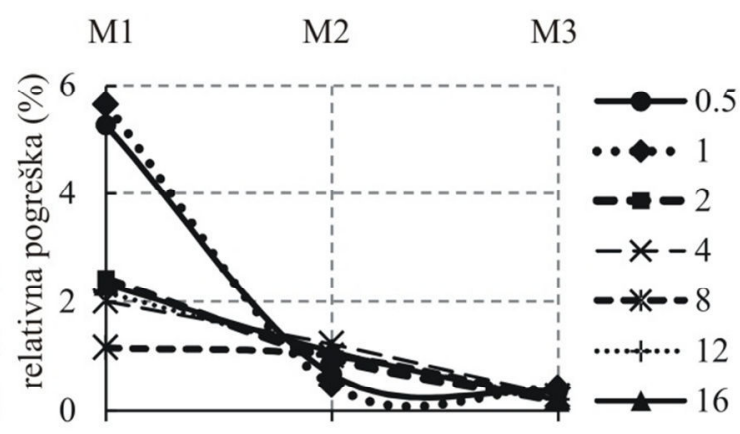

(b)

Crtež 5.22 Jednoosno savijanje (a) ovisnost pogreške o debljini za različite diskretizacije (b) ovisnost pogreške o diskretizaciji za različite debljine

Ako je koeficijent prigušenja jednak nuli, odgovor dobiven sa predloženim MKDE modelom odgovarat će rješenju za slobodne oscilacije sustava. Crtež 5.23 pokazuje krivulju pomaka u vremenu, na sredini ploče za tri različite diskretizacije, uspoređenu sa rješenjem dobivenim iz ABAQUS-a, usvajajući $b=12 \mathrm{~mm}$. Može se uočiti kako sve tri mreže postižu dobro poklapanje rezultata, no međutim kako se gustoća diskretizacije povećava numerički model sve više konvergira ka rješenju iz ABAQUS-a.

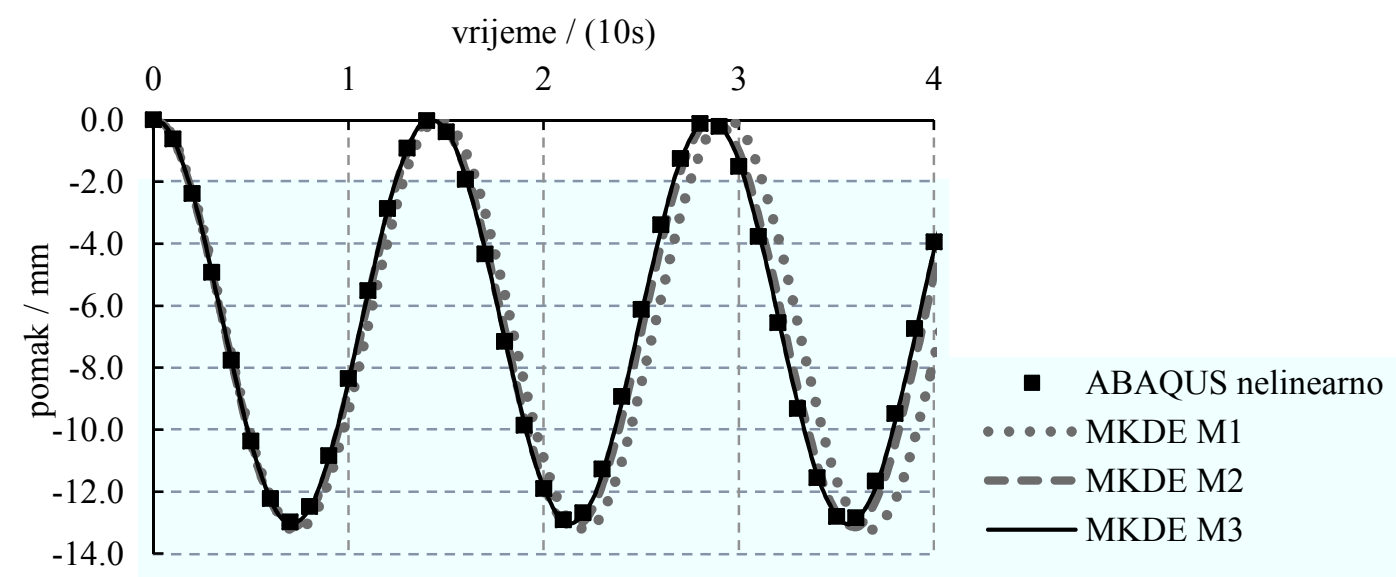

Crtež 5.23 Pomak središta ploče za slobodno osciliranje pod jednoosnim savijanjem 


\subsubsection{Slobodno oslonjena kvadratna ploča pod dvoosnim savijanjem}

Kvadratna slobodno oslonjena ploča, čija geometrija i diskretizacija su prikazane na crtežima 5.24 i 5.19, podložena je gravitacijskom opterećenju u svrhu dodatne verifikacije mehanizma savojne krutosti.
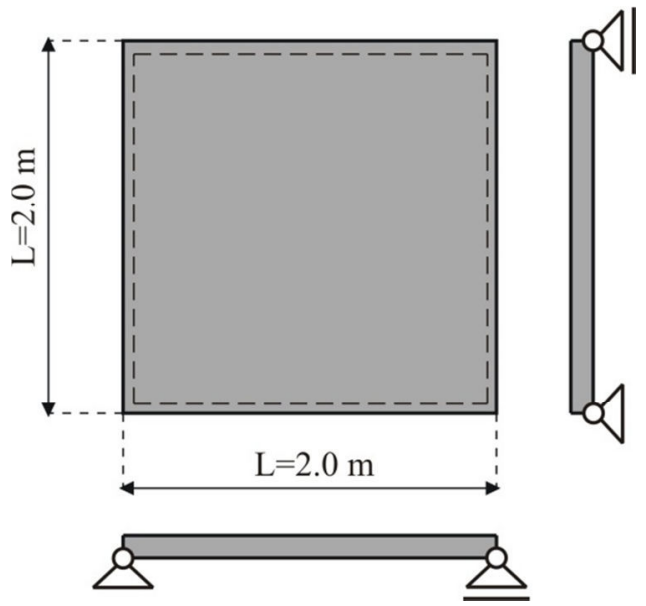

Crtež 5.24 Početna geometrija ploče pod dvoosnim savijanjem

Karakteristike materijala odgovaraju onima u prethodnom primjeru, sa iznimkom Poissonovog koeficijenta koji iznosi 0.3. Debljina je varirana kroz pet slučajeva $(0.5 \mathrm{~mm}, 1 \mathrm{~mm}, 2 \mathrm{~mm}, 4 \mathrm{~mm}$, $8 \mathrm{~mm}, 12 \mathrm{~mm}$ i $16 \mathrm{~mm}$ ), u svrhu analize eventualne veze greške u progibu sa debljinom ploče. Ravnotežni položaj ploče dobiven je uslijed djelovanja prigušenja, tijekom osciliranja ploče počevši od idealno ravne geometrije.

Crtež 5.25 prikazuje pomak središta ploče u vremenu, dobiven predloženim numeričkim modelom uz usvajanje debljine ploče $b=8 \mathrm{~mm}$ i $b=12 \mathrm{~mm}$ sa koeficijentima prigušenja od $\mu=80$ Nms i $\mu=145$ Nms. Primijenjena mreža konačnih elemenata je M3.

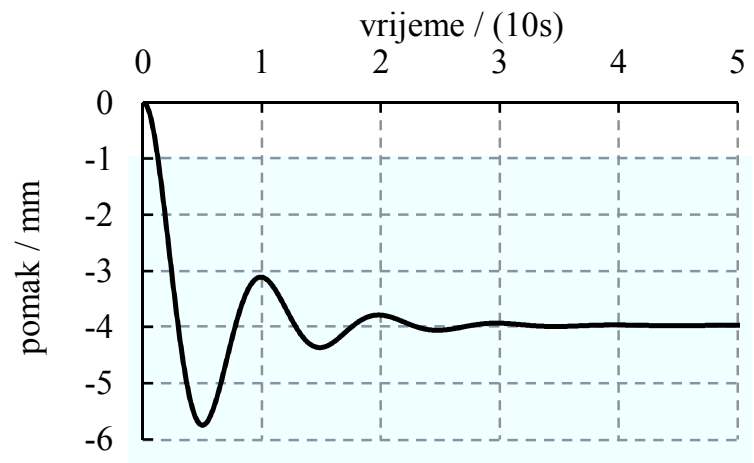

(a)

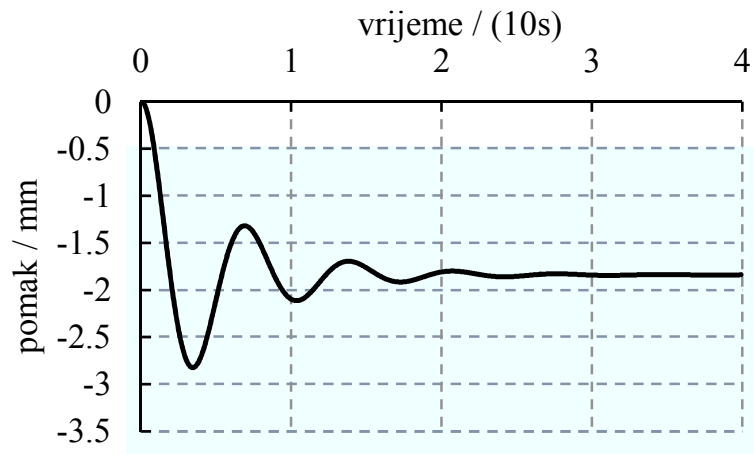

(b)

Crtež 5.25 Pomak središta ploče pod dvoosnim savijanjem za prigušeno osciliranje, za debljinu ploče od

(a) $8 \mathrm{~mm}$, (b) $12 \mathrm{~mm}$ 
Tablica 5.5 prikazuje vrijednosti ravnotežnog pomaka za sedam različitih debljina, dobivene iz predloženog numeričkog modela koristeći tri različite diskretizacije. Također je prikazano i analitičko rješenje ravnotežnog pomaka [V1], te numerička rješenja dobivena koristeći programske pakete ABAQUS [S10] i Scia Engineer [N2]. Za numeričko rješenje korišteno je kod ABAQUS paketa 1600 četverostraničnih osamčvornih konačnih elemenata sa šest stupnjeva slobode u čvoru, dok je kod Scia Engineer paketa korišteno 1600 čevrerostraničnih četveročvornih konačnih elemenata sa šest stupnjeva slobode po čvoru. Može se uočiti kako numeričko rješenje dobiveno linearnom analizom odgovara analitičkom rješenju, što implicira da su mreže usvojene za ABAQUS i Scia Engineer dovoljno fine.

Tablica 5.5 Usporedba numeričkog i analitičkog rješenja za dvoosno savijanje

\begin{tabular}{|c|c|c|c|c|c|c|c|}
\hline Debljina ploče & $\mathbf{0 . 5} \mathbf{~ m m}$ & $\mathbf{1} \mathbf{~ m m}$ & $\mathbf{2} \mathbf{~ m m}$ & $\mathbf{4} \mathbf{~ m m}$ & $\mathbf{8} \mathbf{~ m m}$ & $\mathbf{1 2} \mathbf{~ m m}$ & $\mathbf{1 6} \mathbf{~ m m}$ \\
\hline \hline MKDE M1 & 13.096 & 12.819 & 11.649 & 8.3334 & 3.8203 & 1.7884 & 1.0108 \\
MKDE M2 & 15.908 & 14.947 & 12.149 & 8.9390 & 4.0572 & 1.8893 & 1.0673 \\
MKDE M3 & 16.995 & 15.284 & 12.554 & 9.0318 & 3.9701 & 1.8386 & 1.0380 \\
\hline Analitički & 1060.7 & 265.17 & 66.292 & 16.573 & 4.1432 & 1.8414 & 1.0358 \\
SCIA linearno & 1061.1 & 265.27 & 66.316 & 16.579 & 4.1450 & 1.8421 & 1.0364 \\
ABAQUS linearno & 1061.6 & 265.45 & 66.388 & 16.611 & 4.1602 & 1.8523 & 1.0438 \\
SCIA nelinearno & 16.316 & 15.04 & 12.580 & 9.0599 & 3.9647 & 1.8345 & 1.0357 \\
ABAQUS nelinearno & 17.249 & 15.384 & 12.479 & 9.0681 & 3.9778 & 1.8444 & 1.0430 \\
\hline
\end{tabular}

$\mathrm{Na}$ crtežu 5.26 prikazana je greška numeričkih rezultata dobivenih sa predloženim MKDE modelom u ovisnosti o diskretizaciji i debljini ploče. Rezultati su uspoređivani sa nelinearnim rješenjem dobivenim iz analize ABAQUS-om. Na crtežu 5.26 (a) vidljivo je kako kod finijih mreža debljina ploče nema značajan utjecaj na pogrešku progiba. Na crtežu 5.26 (b) se može uočiti kako sa proguščenjem mreže konačnih elemenata numerički rezultati dobiveni predloženim MKDE modelom konvergiraju ka onima dobivenima sa ABAQUS-om, te postižu izvrsno poklapanje rezultata.

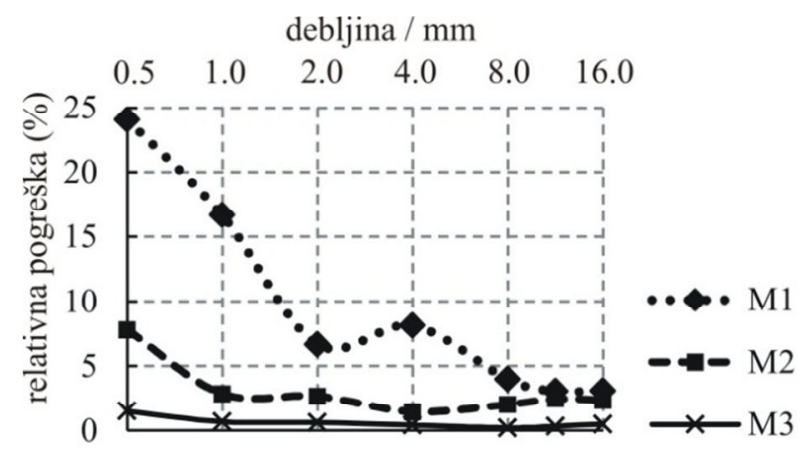

(a)

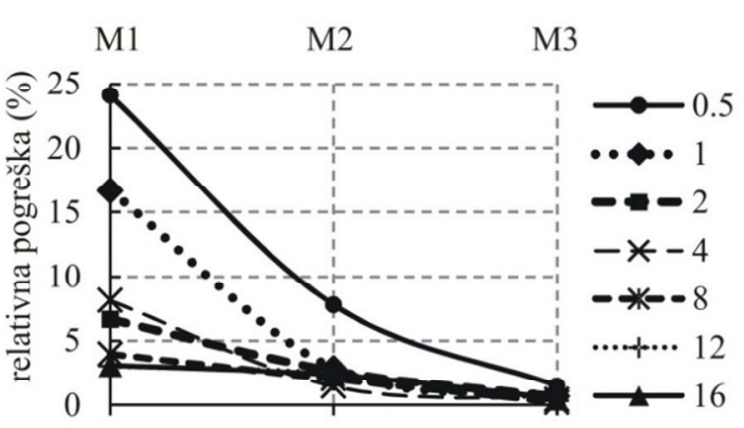

(b)

Crtež 5.26 Dvoosno savijanje (a) ovisnost pogreške o debljini za različite diskretizacije (b) ovisnost pogreške o diskretizaciji za različite debljine 
Ako je koeficijent prigušenja jednak nuli, odgovor dobiven sa predloženim MKDE modelom odgovarat će rješenju za slobodne oscilacije sustava. Crtež 5.27 pokazuje krivulju pomaka u vremenu, na sredini ploče za tri različite diskretizacije, uspoređenu sa rješenjem dobivenim iz ABAQUS-a, usvajajući $b=12 \mathrm{~mm}$. Može se uočiti kako sve tri mreže postižu dobro poklapanje rezultata, i kako sa proguščenjem diskretizacije numerički model sve više konvergira ka rješenju iz ABAQUS-a.

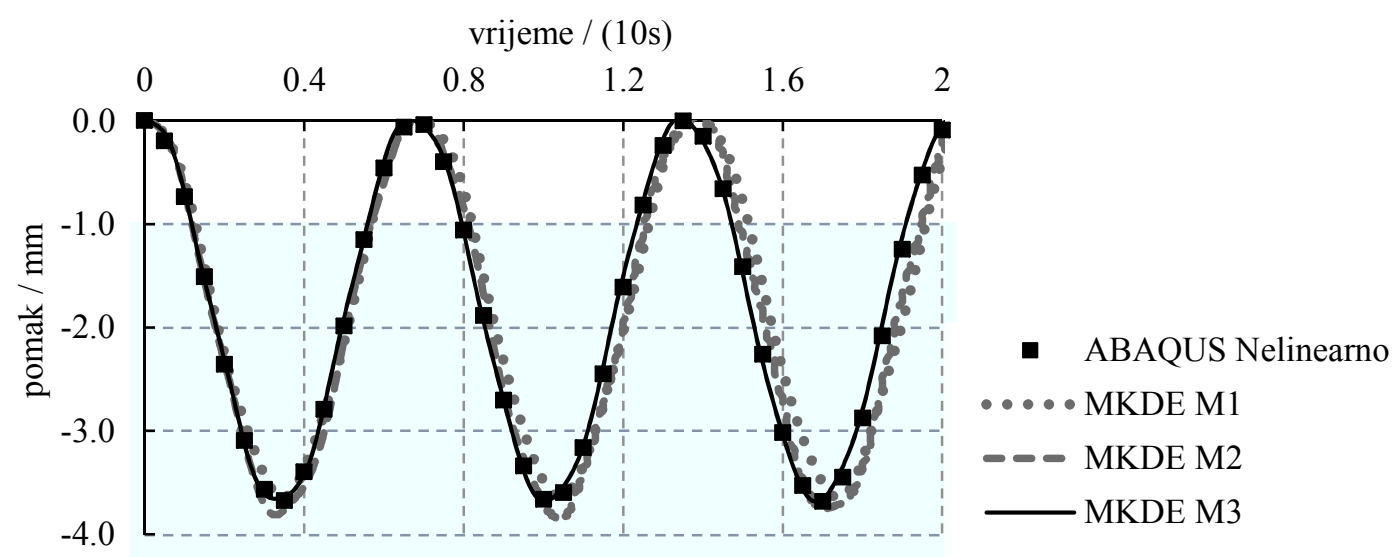

Crtež 5.27 Pomak središta ploče za slobodno osciliranje pod dvoosnim savijanjem

\subsubsection{Slobodno oslonjena kružna ploča pod gravitacijskim opterećenjem}

Slobodno oslonjena kružna ploča podložena gravitacijskom opterećenju odabrana je za dodatnu verifikaciju savojnog mehanizma. Radijus ploče iznosi $1 \mathrm{~m}$, dok mehaničke karakteristike odgovaraju onima korištenima u prethodnom primjeru. Da bi se analizirala eventualna veza greške u progibu na sredini ploče sa debljinom ploče, debljina je varirana kroz pet slučajeva $(0.5 \mathrm{~mm}, 1$ mm, $2 \mathrm{~mm}, 4 \mathrm{~mm}, 8 \mathrm{~mm}, 12 \mathrm{~mm}$ i $16 \mathrm{~mm}$ ). Ravnotežni položaj dobiven je kao rezultat djelovanja prigušenja na slobodne vibracije ploče, počevši od idealno ravne geometrije.

Analiza je provedena za tri mreže konačnih elemenata (R1, R2 i R3), sa diskretizacijama kao što je pokazano na crtežu 5.28. Mreže R1, R2 i R3 sastoje se od 45, 153 i 637 trokutnih konačnih elemenata.

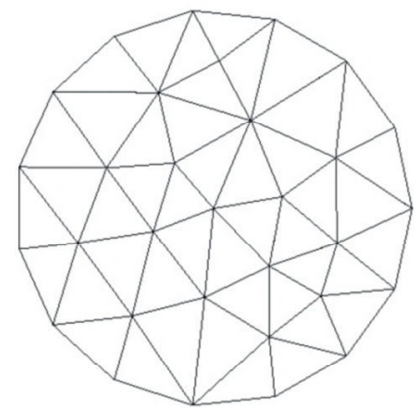

(a)

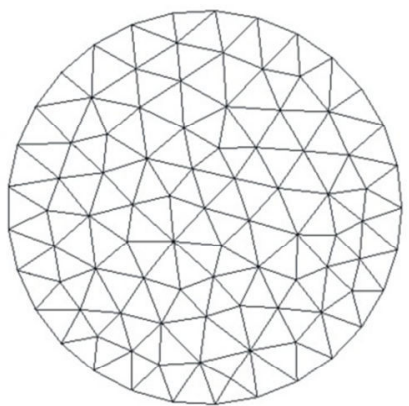

(b)

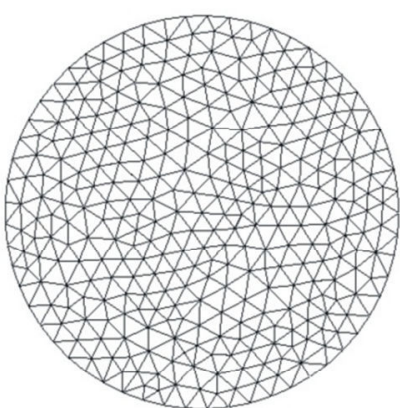

(c)

Crtež 5.28 Diskretizacija kružne ploče (a) R1 (b) R2 (c) R3 
$\mathrm{Na}$ crtežu 5.29 prikazan je pomak središta ploče u vremenu, dobiven predloženim numeričkim modelom uz usvajanje debljine ploče od ploče $b=8 \mathrm{~mm}$ i $b=12 \mathrm{~mm}$, sa koeficijentom prigušenja $\mu=80 \mathrm{Nms}$ i primijenjenom M3 diskretizacije.

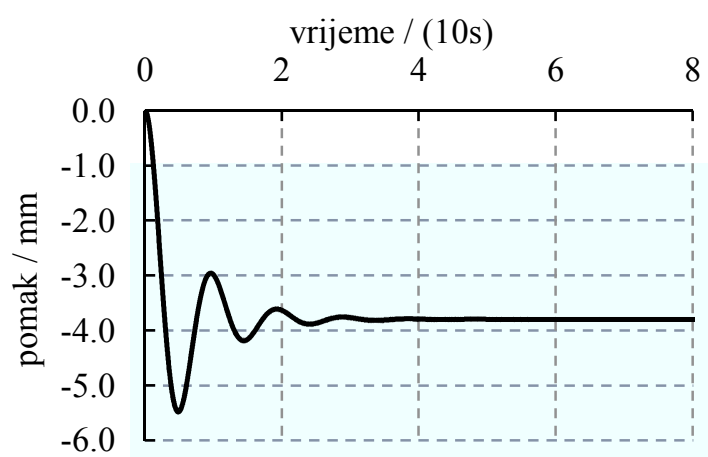

(a)

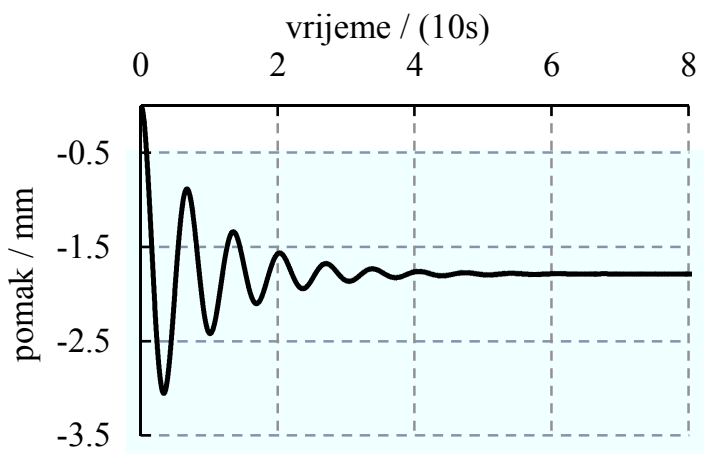

(b)

Crtež 5.29 Pomak središta kružne ploče za prigušeno osciliranje, za debljinu ploče od (a) $8 \mathrm{~mm}$, (b) $12 \mathrm{~mm}$

Tablica 5.6 prikazuje vrijednosti ravnotežnog pomaka za sedam različitih debljina, dobivene iz predloženog numeričkog modela koristeći tri različite diskretizacije. Prikazano je i analitičko rješenje ravnotežnog pomaka [V1], te numerička rješenja dobivena koristeći programske pakete ABAQUS [S10] i Scia Engineer [N2]. Za numeričko rješenje korišteno je kod ABAQUS paketa 1600 četverostraničnih osamčvornih konačnih elemenata sa šest stupnjeva slobode u čvoru, dok je kod Scia Engineer paketa korišteno 1600 čevrerostraničnih četveročvornih konačnih elemenata sa šest stupnjeva slobode po čvoru. Može se uočiti kako numeričko rješenje dobiveno linearnom analizom odgovara analitičkom rješenju, što implicira da su mreže usvojene za ABAQUS i Scia Engineer dovoljno fine.

Tablica 5.6 Usporedba numeričkog i analitičkog rješenja za kružnu ploču

\begin{tabular}{|c|c|c|c|c|c|c|c|}
\hline Debljina ploče & $\mathbf{0 . 5} \mathbf{~ m m}$ & $\mathbf{1} \mathbf{~ m m}$ & $\mathbf{2} \mathbf{~ m m}$ & $\mathbf{4} \mathbf{~ m m}$ & $\mathbf{8} \mathbf{~ m m}$ & $\mathbf{1 2} \mathbf{~ m m}$ & $\mathbf{1 6} \mathbf{~ m m}$ \\
\hline \hline MKDE M1 & 8.6271 & 8.5805 & 8.3570 & 7.2185 & 3.5836 & 1.6882 & 0.95472 \\
MKDE M2 & 9.4281 & 9.3279 & 8.9771 & 7.6373 & 3.7595 & 1.7708 & 1.0014 \\
MKDE M3 & 10.280 & 9.7966 & 9.2097 & 7.7598 & 3.8002 & 1.7884 & 1.0113 \\
\hline Analitički & 1040.1 & 260.03 & 65.008 & 16.252 & 4.0630 & 1.8058 & 1.0157 \\
SCIA linearno & 1040.1 & 260.03 & 65.007 & 16.252 & 4.0630 & 1.8058 & 1.0159 \\
ABAQUS linearno & 1040.0 & 260.02 & 64.997 & 16.251 & 4.0630 & 1.8060 & 1.0160 \\
SCIA nelinearno & 10.358 & 9.8957 & 9.2850 & 7.8048 & 3.8123 & 1.7932 & 1.0141 \\
ABAQUS nelinearno & 10.381 & 9.9072 & 9.2899 & 7.8058 & 3.8145 & 1.7951 & 1.0149 \\
\hline
\end{tabular}

Na crtežu 5.30 prikazana je greška numeričkih rezultata dobivenih sa predloženim MKDE modelom u ovisnosti o diskretizaciji i debljini ploče. Rezultati su uspoređivani sa nelinearnim rješenjem dobivenim iz analize ABAQUS-om. Na crtežu 5.30 (a) vidljivo je kako kod finijih mreža debljina ploče nema značajan utjecaj na pogrešku progiba. Na crtežu 5.30 (b) se može 
uočiti kako sa proguščenjem mreže konačnih elemenata numerički rezultati dobiveni predloženim MKDE modelom konvergiraju ka onima dobivenima sa ABAQUS-om, te postižu izvrsno poklapanje rezultata.

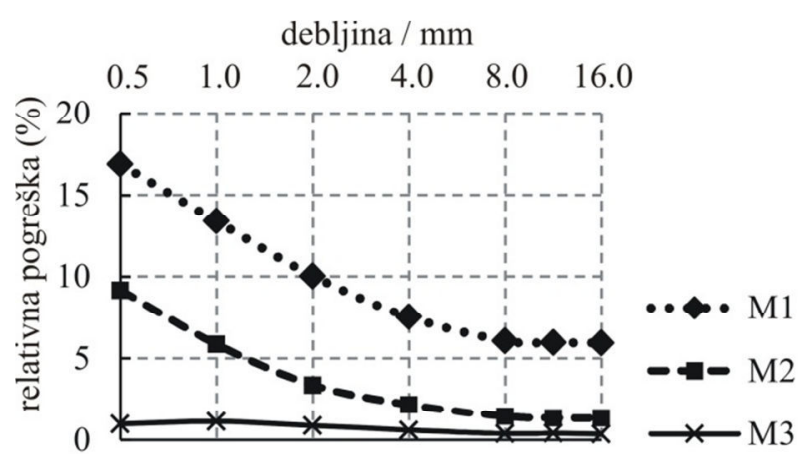

(a)

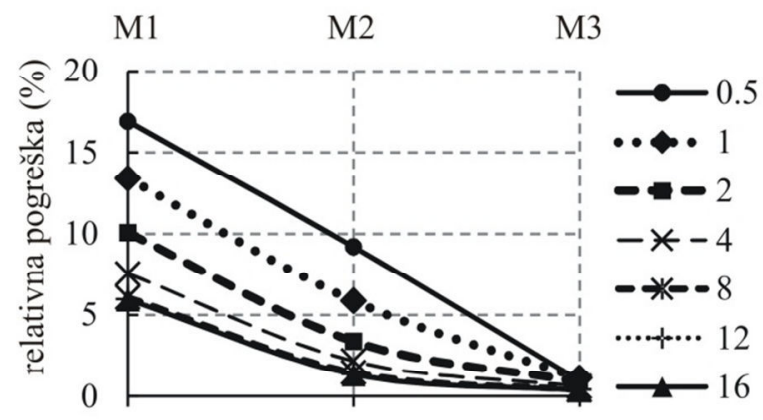

(b)

Crtež 5.30 Kružna ploča (a) ovisnost pogreške o debljini za različite diskretizacije (b) ovisnost pogreške o diskretizaciji za različite debljine

Ako je koeficijent prigušenja jednak nuli, odgovor dobiven sa predloženim MKDE modelom odgovarat će rješenju za slobodne oscilacije sustava. Crtež 5.31 pokazuje krivulju pomaka u vremenu, na sredini ploče za tri različite diskretizacije, uspoređenu sa rješenjem dobivenim iz ABAQUS-a, usvajajući $b=12 \mathrm{~mm}$. Može se uočiti kako sve tri mreže postižu dobro poklapanje rezultata, no međutim kako se gustoća diskretizacije povećava numerički model sve više konvergira ka rješenju iz ABAQUS-a.

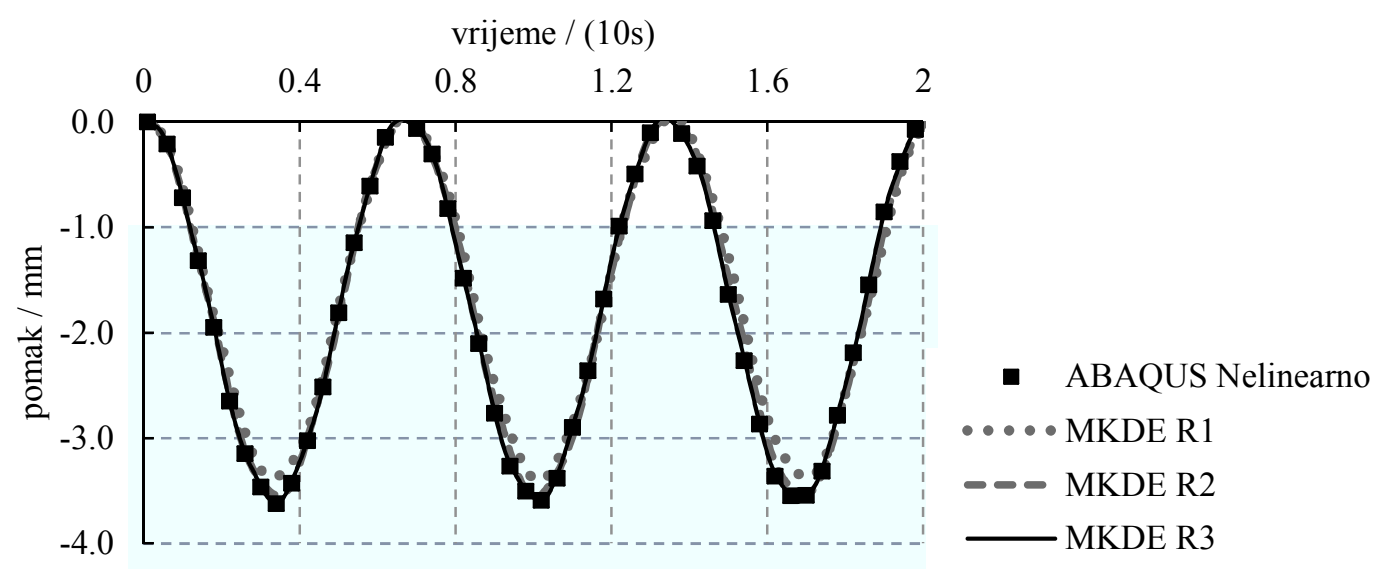

Crtež 5.31 Pomak središta kružne ploče za slobodne oscilacije 


\subsection{5 Čelični luk pod gravitacijskim opterećenjem}

Čelični luk prikazan na crtežu 5.32, opterećen gravitacijskim opterećenjem od vlastite težine, odabran je u svrhu validacije interakcijskog djelovanja membranskog i savojnog mehanizma. Materijalne karakteristike odgovaraju onima usvojenima u primjeru 5.5.2. Širina poprečnog presjeka uzeta je kao $1 \mathrm{~m}$, dok je visina varirana u vrijednostima od $25 \mathrm{~mm}, 50 \mathrm{~mm}$, $100 \mathrm{~mm}$ i $200 \mathrm{~mm}$.

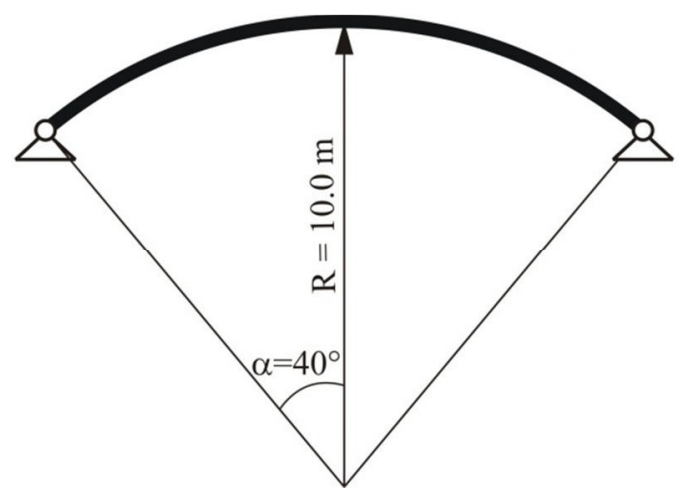

Crtež 5.32 Početna geometrija čeličnog luka

Analiza je provedena za tri mreže konačnih elemenata (L1, L2 i L3), sa diskretizacijama kao što je pokazano na crtežu 5.33. Mreže L1, L2 i L3 sastoje se od 242, 420 i 1174 trokutnih konačnih elemenata.

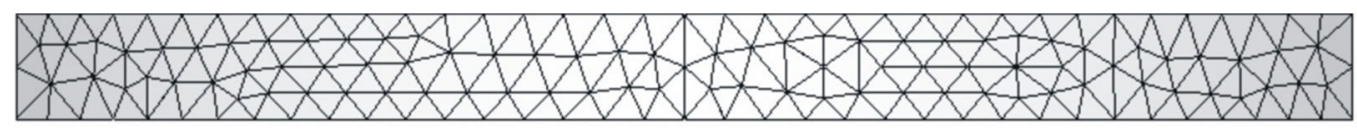

(a)

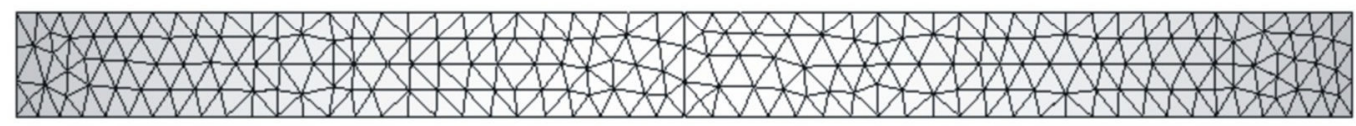

(b)

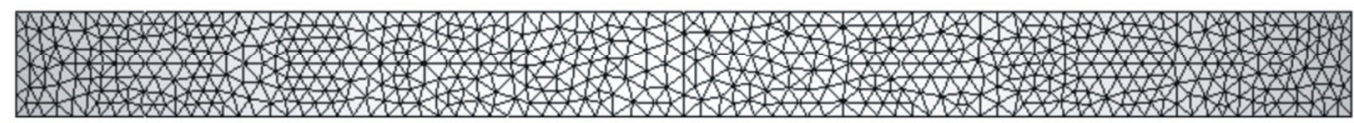

(c)

Crtež 5.33 Diskretizacija čeličnog luka (a) L1 (b) L2 (c) L3

Na crtežu 5.34 prikazan je pomak središta luka u vremenu, dobiven predloženim numeričkim modelom uz usvajanje debljine ploče $b=25 \mathrm{~mm}$, koeficijenta prigušenja od $\mu=4000 \mathrm{Nms}$, te primijenjenu L3 diskretizacije. 


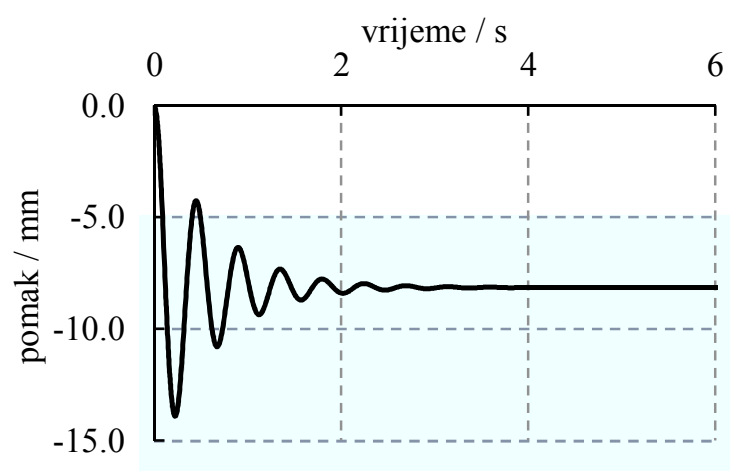

Crtež 5.34 Pomak središta čeličnog luka za prigušeno osciliranje, za debljinu luka od $25 \mathrm{~mm}$

Tablica 5.7 prikazuje vrijednosti ravnotežnog pomaka za četiri različite debljine, dobivene iz predloženog numeričkog modela koristeći tri različite diskretizacije. Prikazano je i numeričko rješenje dobiveno koristeći programski paket ABAQUS [S10], koristeći 800 četverostraničnih osamčvornih konačnih elemenata sa šest stupnjeva slobode u čvoru. Da bi se osigurala zadovoljavajuća diskretizacije numeričkog rješenja u ABAQUS-u, mreža konačnih elemenata progušćivana je sve dok razlika u rješenjima dvaju uzastopnih gustoća nije bila manja od $0.005 \%$.

Tablica 5.7 Usporedba numeričkih rješenja za središnji progib čeličnog luka

\begin{tabular}{|c|c|c|c|c|}
\hline Debljina luka & $\mathbf{2 5} \mathbf{~ m m}$ & $\mathbf{5 0} \mathbf{~ m m}$ & $\mathbf{1 0 0} \mathbf{~ m m}$ & $\mathbf{2 0 0} \mathbf{~ m m}$ \\
\hline \hline MKDE L1 & 8.1312 & 1.8122 & 0.48255 & 0.16319 \\
MKDE L2 & 8.1413 & 1.8153 & 0.48333 & 0.16338 \\
MKDE L3 & 8.1453 & 1.8161 & 0.48350 & 0.16340 \\
\hline ABAQUS nelinearno & 8.1497 & 1.8174 & 0.48417 & 0.16389 \\
\hline
\end{tabular}

$\mathrm{Na}$ crtežu 5.35 prikazana je greška numeričkih rezultata dobivenih sa predloženim MKDE modelom u ovisnosti o diskretizaciji i debljini luka. Na crtežu 5.35 (a) vidljivo je kako kod finijih mreža debljina ploče nema značajan utjecaj na pogrešku progiba. Na crtežu 5.35 (b) se može uočiti kako sa proguščenjem mreže konačnih elemenata numerički rezultati dobiveni predloženim MKDE modelom konvergiraju ka onima dobivenima sa ABAQUS-om, te postižu izvrsno poklapanje rezultata.

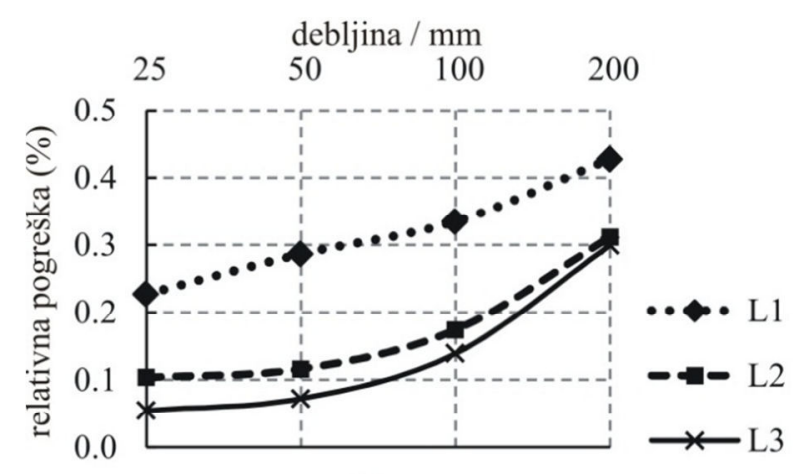

(a)

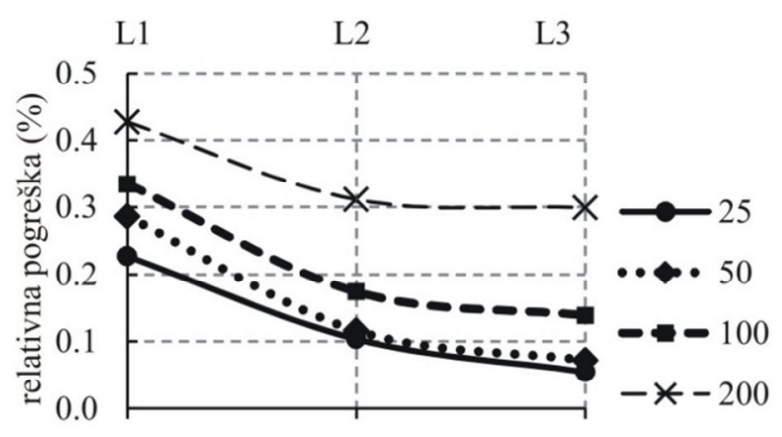

(b)

Crtež 5.35 Čelični luk (a) ovisnost pogreške o debljini za različite diskretizacije (b) ovisnost pogreške o diskretizaciji za različite debljine 
Ako je koeficijent prigušenja jednak nuli, odgovor dobiven sa predloženim MKDE modelom odgovarat će rješenju za slobodne oscilacije sustava. Crtež 5.36 pokazuje krivulju pomaka u vremenu, na sredini luka za tri različite diskretizacije, uspoređenu sa rješenjem dobivenim iz ABAQUS-a, usvajajući $b=25 \mathrm{~mm}$. Može se uočiti kako sve tri mreže postižu izvrsno poklapanje rezultata.

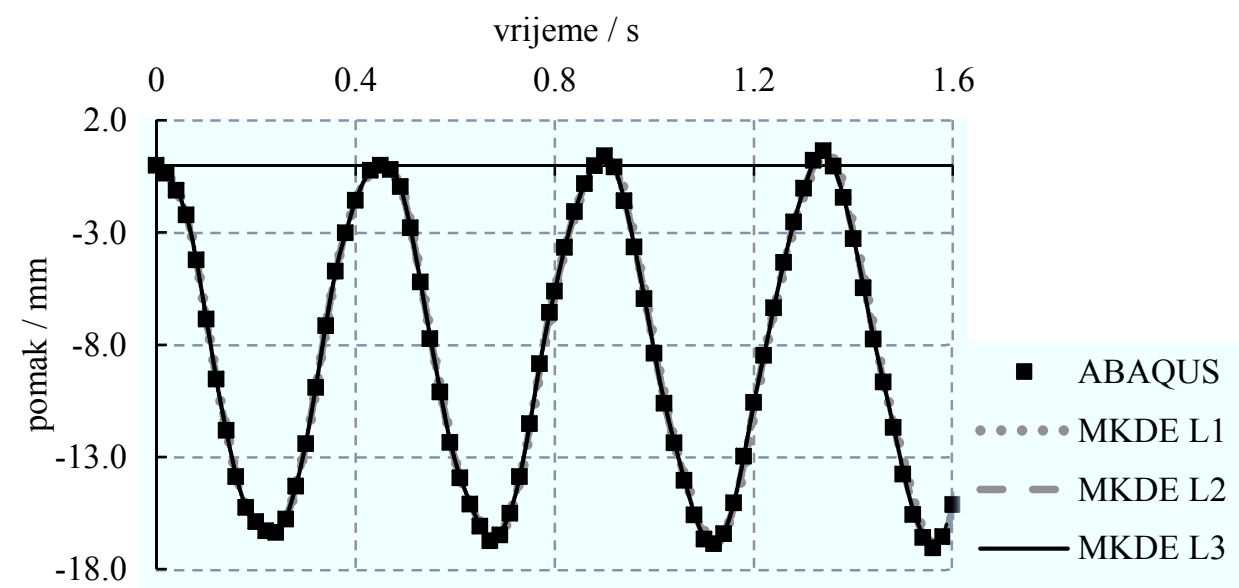

Crtež 5.36 Pomak središta čeličnog luka za slobodne oscilacije, za debljinu luka od $25 \mathrm{~mm}$

\subsubsection{Ljuska pod gravitacijskim opterećenjem}

Čelična ljuska, prikazana na crtežu 5.37, odabrana je u svrhu dodatne validacije interakcijskog djelovanja membranskog i savojnog mehanizma. Geometrija ljuske izvedena je od $1 / 8$ sfere radijusa $4 \mathrm{~m}$, te se nalazi pod gravitacijskim opterećenjem. Debljina ljuske varirana je u vrijednostima od $10 \mathrm{~mm}, 25 \mathrm{~mm}, 50 \mathrm{~mm}$ i $100 \mathrm{~mm}$. Materijalne karakteristike odgovaraju onima usvojenima u primjeru 5.5.3.
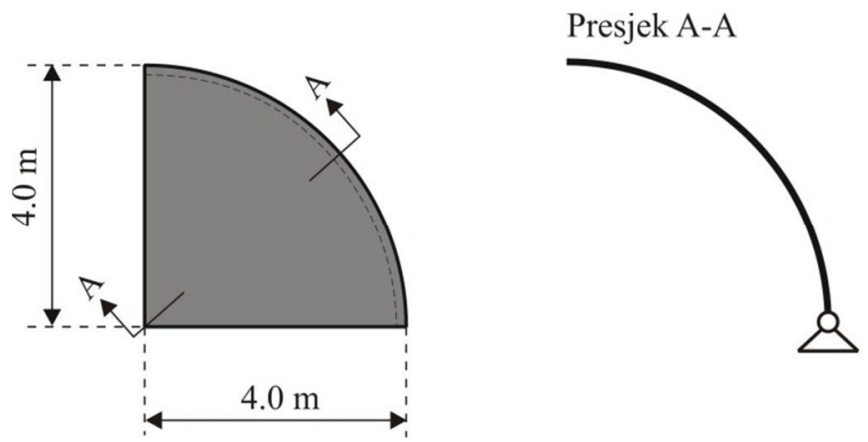

Crtež 5.37 Početna geometrija čelične ljuske

Analiza je provedena za tri mreže konačnih elemenata (K1, K2 i K3), sa diskretizacijama kao što je pokazano na crtežu 5.38. Mreže K1, K2 i K3 sastoje se od 1391, 2413 i 4729 trokutnih konačnih elemenata. 


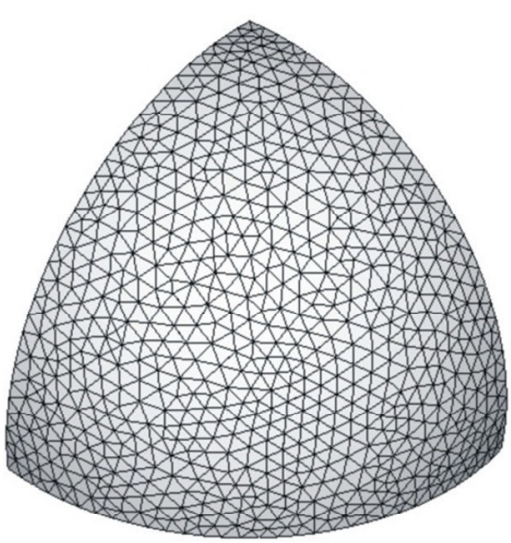

(a)

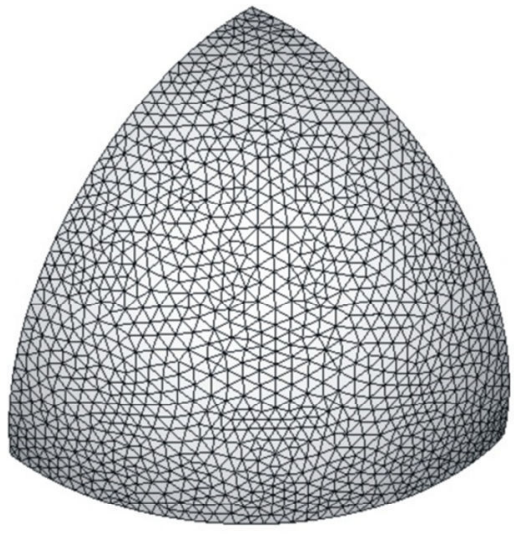

(b)

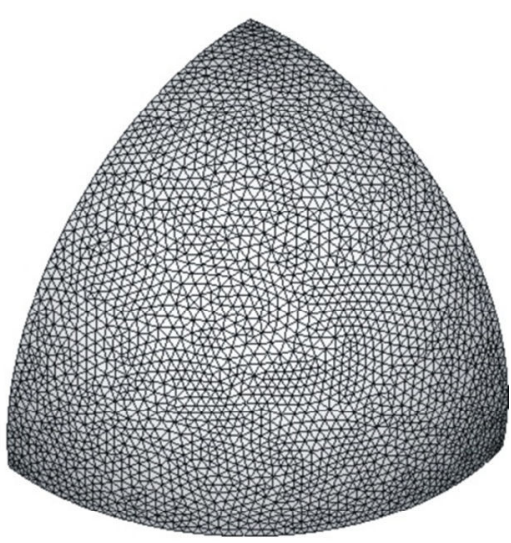

(c)

Crtež 5.38 Diskretizacija čelične ljuske (a) K1 (b) K2 (c) K3

Na crtežu prikazan je pomak vrha ljuske u vremenu, dobiven predloženim numeričkim modelom uz usvajanje debljine ploče $b=25 \mathrm{~mm}$, koeficijenta prigušenja od $\mu=2300 \mathrm{Nms}$, te primijenjenu K3 diskretizacije.

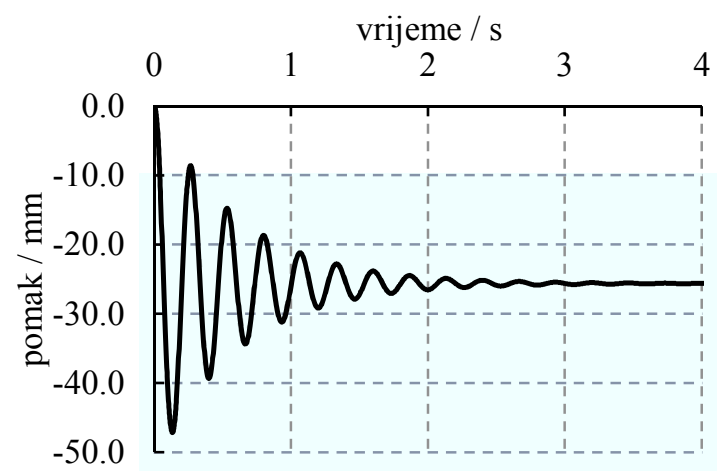

Crtež 5.39 Pomak vrha čelične ljuske za prigušeno osciliranje, za debljinu luka od $25 \mathrm{~mm}$

Tablica 5.8 prikazuje vrijednosti ravnotežnog pomaka za četiri različite debljine, dobivene iz predloženog numeričkog modela koristeći tri različite diskretizacije. Prikazano je i numeričko rješenje dobiveno koristeći programski paket ABAQUS [S10], koristeći 12172 osamčvornih konačnih elemenata sa šest stupnjeva slobode u čvoru. Da bi se osigurala zadovoljavajuća diskretizacije numeričkog rješenja u ABAQUS-u, mreža konačnih elemenata progušćivana je sve dok razlika u rješenjima dvaju uzastopnih gustoća nije bila manja od $0.005 \%$.

Tablica 5.8 Usporedba numeričkih rješenja za središnji progib čelične ljuske

\begin{tabular}{|c|c|c|c|c|}
\hline Debljina ljuske & $\mathbf{1 0} \mathbf{~ m m}$ & $\mathbf{2 5} \mathbf{~ m m}$ & $\mathbf{5 0} \mathbf{~ m m}$ & $\mathbf{1 0 0} \mathbf{~ m m}$ \\
\hline \hline MKDE K1 & 135.57 & 25.420 & 8.4561 & 2.8507 \\
MKDE K2 & 135.37 & 25.555 & 8.5204 & 2.8671 \\
MKDE K3 & 135.59 & 25.647 & 8.5551 & 2.8764 \\
\hline ABAQUS nelinearno & 136.83 & 25.928 & 8.6764 & 2.9413 \\
\hline
\end{tabular}


$\mathrm{Na}$ crtežu 5.40 prikazana je greška numeričkih rezultata dobivenih sa predloženim MKDE modelom u ovisnosti o diskretizaciji i debljini ljuske. Na crtežu 5.40 (a) vidljivo je kako je pogreška značajnija kod debljih ploča, što je u skladu sa usvojenim pretpostavkama za proračun tankih ploča. Na crtežu 5.40 (b) se može uočiti kako sa proguščenjem mreže konačnih elemenata numerički rezultati dobiveni predloženim MKDE modelom konvergiraju ka onima dobivenima sa ABAQUS-om, te postižu izvrsno poklapanje rezultata.

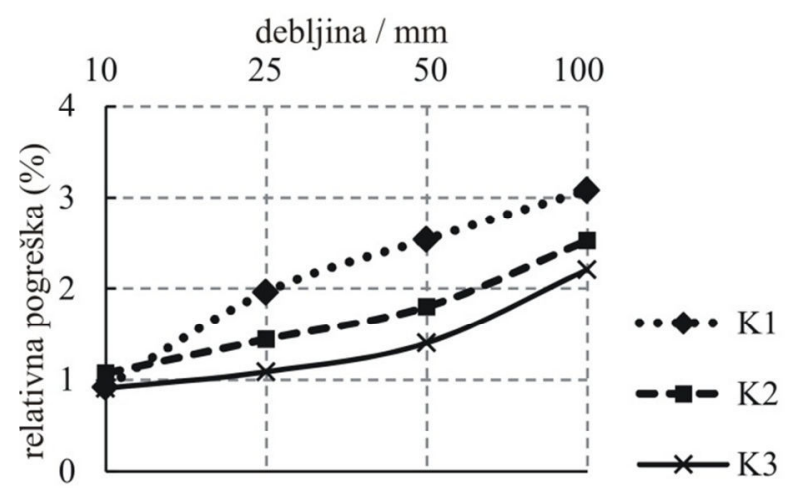

(a)

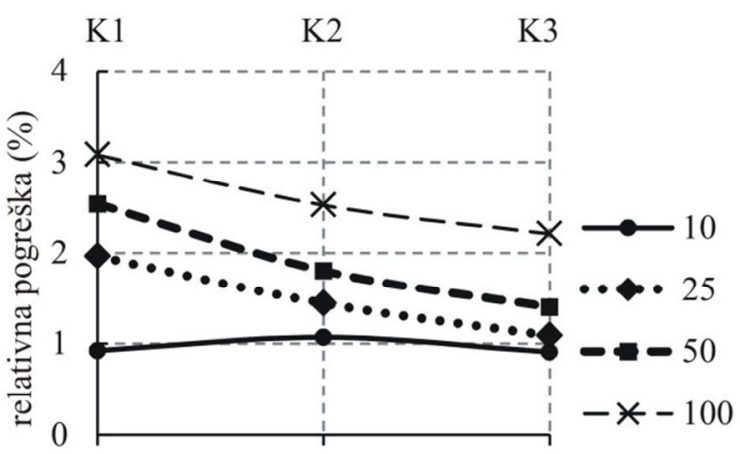

(b)

Crtež 5.40 Čelična ljuska (a) ovisnost pogreške o debljini za različite diskretizacije (b) ovisnost pogreške o diskretizaciji za različite debljine

Ako je koeficijent prigušenja jednak nuli, odgovor dobiven sa predloženim MKDE modelom odgovarat će rješenju za slobodne oscilacije sustava. Crtež 5.41 pokazuje krivulju pomaka u vremenu, na vrhu ljuske za tri različite diskretizacije, uspoređenu sa rješenjem dobivenim iz ABAQUS-a koristeći 315-osamčvornih konačnih elemenata i usvajajući $b=25 \mathrm{~mm}$. Može se uočiti kako sve tri mreže postižu odlično poklapanje rezultata.

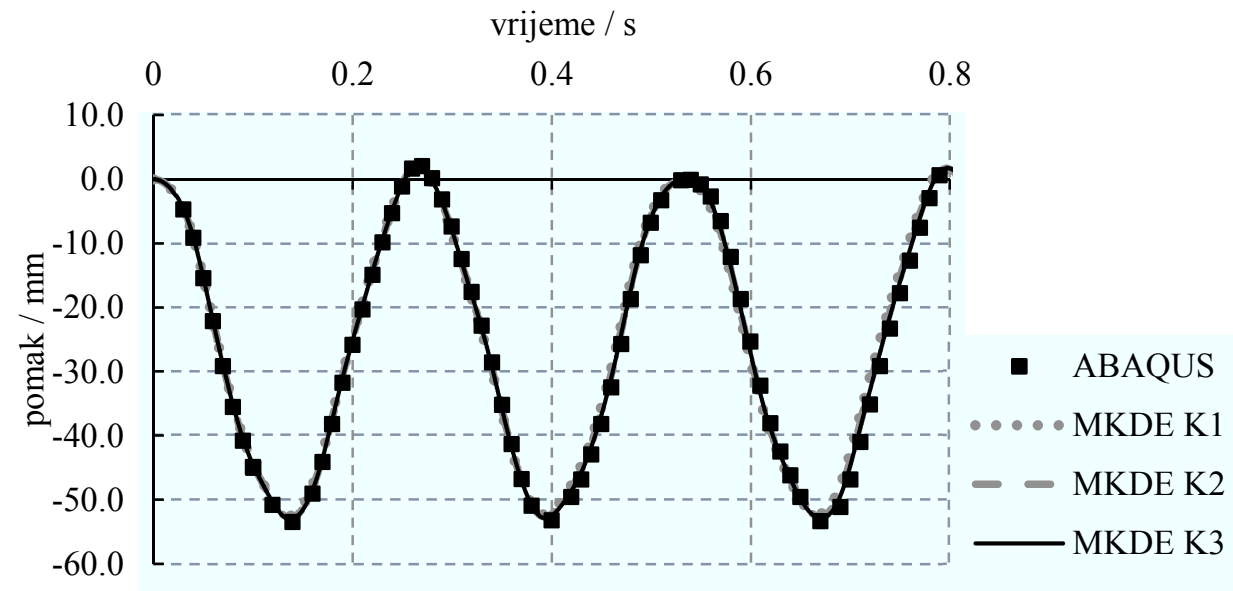

Crtež 5.41 Pomak vrha čelične ljuske za slobodne oscilacije, za debljinu luka od $25 \mathrm{~mm}$ 


\subsubsection{Konzola podložena posmičnoj sili na slobodnom kraju}

Konzola podložena posmičnoj sili na slobodnom kraju, kako je prikazano na crtežu 5.42, odabrana je u svrhu validacije predloženog modela za slučajeve upetih rubnih uvjeta, te konačnih pomaka i rotacija. Konzola ima modul elastičnosti od $E=210 \mathrm{GPa}$, širina poprečnog presjeka iznosi $1 \mathrm{~m}$, dok je visina poprečnog presjeka $200 \mathrm{~mm}$. Diskretizacija ploče izvršena je pomoću 154 konačnih elemenata, kako je prikazano na crtežu 5.42(b).

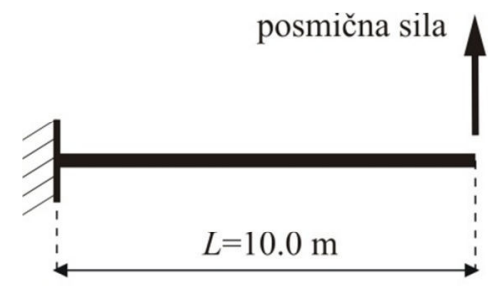

(a)

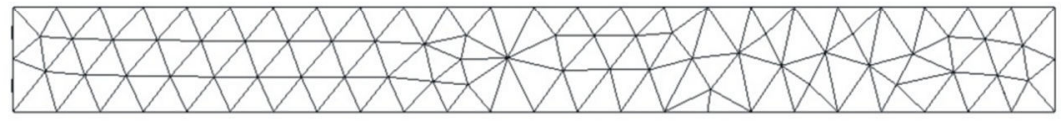

(b)

Crtež 5.42 (a) Početna geometrija konzole (b) pripadajuća diskretizacija konzole

Crtež 5.43 prikazuje dijagrame vertikalne sile na slobodnom kraju konzole u ovisnosti o vertikalnom i horizontalnom pomaku slobodnog kraja. Numerički pomak dobiven predloženim modelom uspoređen je sa rješenjem dobivenim ABAQUS paketom [S10], koristeći 100 tročvornih grednih elemenata.

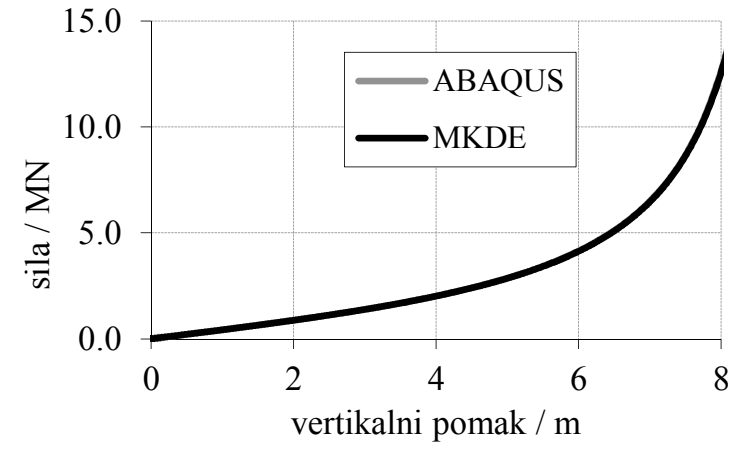

(a)

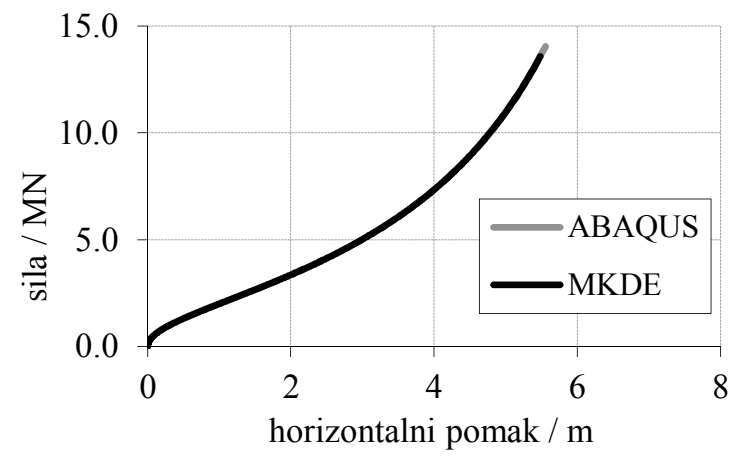

(b)

Crtež 5.43 Usporedba pomaka na slobodnom kraju konzole (a) sila-vertikalni pomak, (b) sila-horizontalni pomak.

$\mathrm{Na}$ crtežu je vidljivo kako su numerička rješenja usuglašena, odnosno kako je predloženi model ljusaka sposoban predvidjeti ponašanje konstrukcije i uslijed konačnih pomaka i konačnih rotacija. Pripadni deformirani oblici konstrukcije, za četiri različite djelujuće sile, prikazani su na crtežu 5.44. 


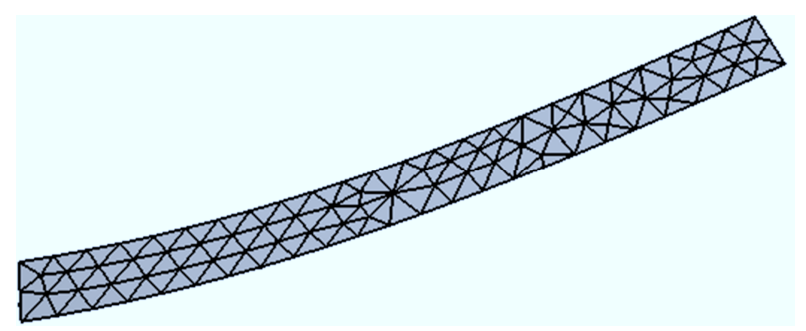

(a)

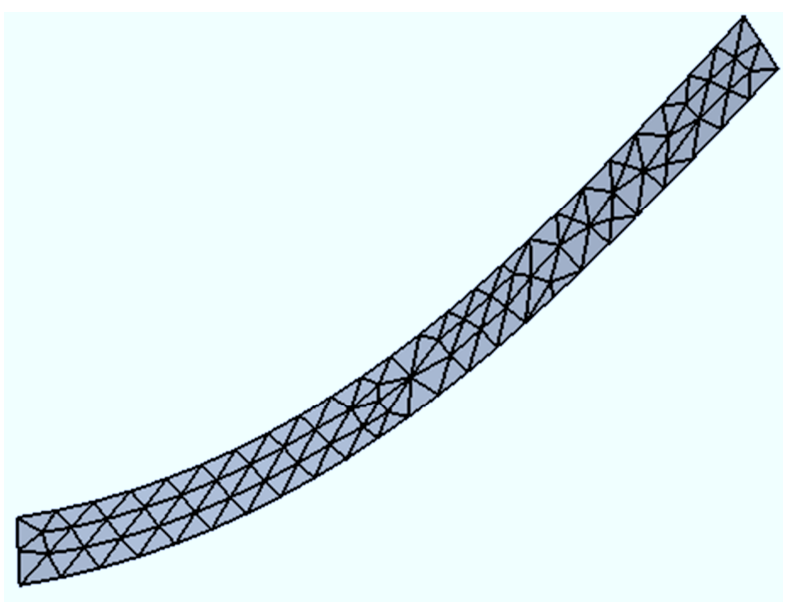

(c)

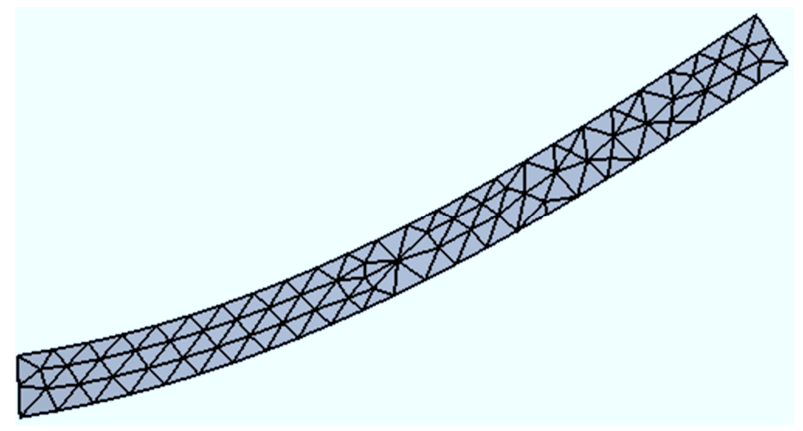

(b)

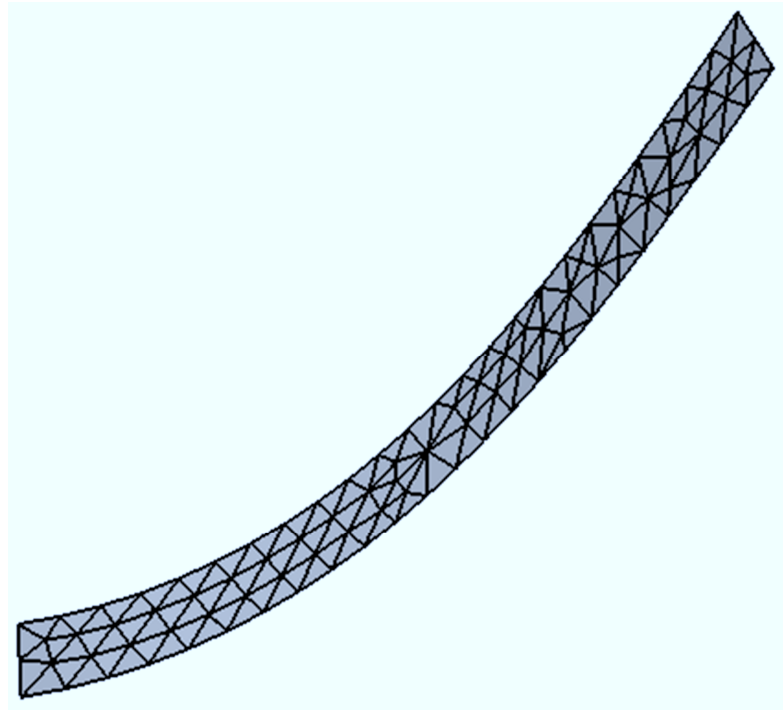

(d)

Crtež 5.44 Deformirani oblici konzole za djelujuće opterećenje od (a) $1.1 \mathrm{MN}$, (b) $2.0 \mathrm{MN}$, (c) $3.6 \mathrm{MN}$, (d) 4.9 MN 


\section{PRIMJENA RAZVIJENOG MODELA U ANALIZI KONSTRUKCJA LUKOVA I LJUSAKA}

U ovom poglavlju prikazani su neki od mogućih načina primjene novo razvijenih numeričkih modela za konstrukcije lukova i ljusaka.

U prvom primjeru analizirana je konstrukcija luka podložena potresnom opterećenju. U drugom primjeru analizirano je ponašanje tlačno opterećene ploče slobodno oslonjene na dva nasuprotna kraja, dok je u trećem primjeru analizirano ponašanje tlačno opterećene ploče slobodno oslonjene na sva četiri kraja. Ova dva primjera odabrana su iz razloga što rubni uvjeti ploče oslonjene na dva kraja uzrokuju gubitak stabilnosti sličan onome kod proste grede, dok ploča oslonjena na sva četiri kraja uzrokuju gubitak stabilnost nakon kojeg slijedi poznati efekt očvrščavanja ploče. U četvrtom primjeru analizirano je ponašanje tlačno opterećenog čeličnog cilindra, skupa sa prikazom gubitka stabilnosti i osvrtom na do sada predložena rješenja i eksperimentalne analize.

Šira primjena razvijenih modela uključuje vremensku analizu proizvoljnih konstrukcija tankih ploča i ljusaka, te tankih ravninskih lučnih i grednih elemenata podloženih dinamičkim opterećenjima. Također, u sklopu predloženog modela razvijena je vizualizacija rezultata koristeći open-source platformu Paraview. 


\section{1 ČELIČNI LUK PODLOŽEN POTRESNOM OPTEREĆENJU}

Čelični kružni luk prikazan na crtežu 6.1, podložen je potresnom opterećenju, a sve u svrhu prikaza primjene predloženog numeričkog modela za dinamičku analizu lučnih konstrukcija. Visina poprečnog presjeka uzeta je kao $100 \mathrm{~mm}$, dok je širina $1000 \mathrm{~mm}$.

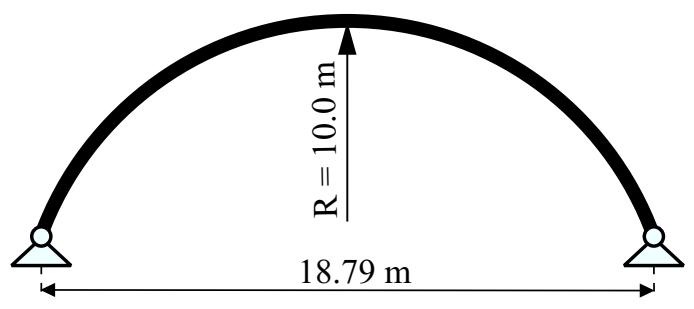

Crtež 6.1 Geometrija čeličnog luka

Karakteristika odabranog materijala je E=210 GPa, gustoća $\rho=7850 \mathrm{~kg} / \mathrm{m} 3$, dok je za konstantu gravitacije usvojeno $\mathrm{g}=10 \mathrm{~m} / \mathrm{s} 2$. Luk je opterećen vlastitom težinom i potresnom ubrzanju prikazanom na crtežu 6.2, skaliranog na vršno ubrzanje od $a_{g}=0.5 \mathrm{~g}$. Koeficijent prigušenja usvojen je kao $\mu=91 \mathrm{kNm}^{2} / \mathrm{s}$.

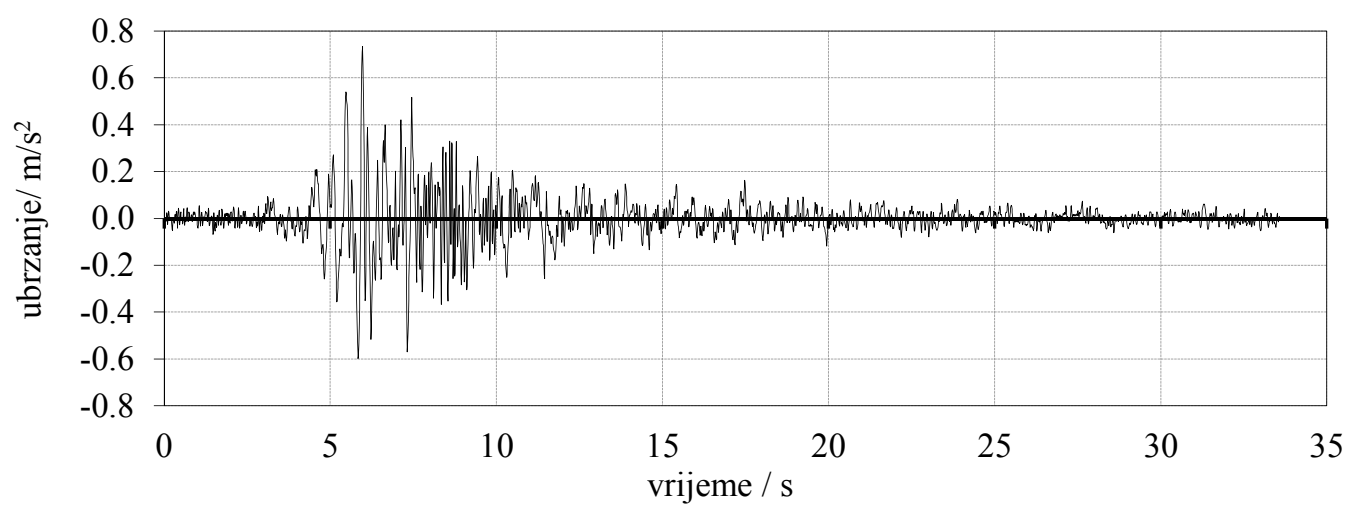

Crtež 6.2 Horizontalna akceleracija snimljena za vrijeme potresa Petrovac (Crna Gora 1979.)

Horizintalni pomak točke vrha luka, dobiven predloženim numeričkim modelom, prikazan je na crtežu 6.3. Potrebno je naglasiti kako proračun uz konačne pomake i rotacije uključuje i eventualni gubitak stabilnosti. Također, u sklopu predloženog modela je osim unosa potresnog opterećenja omogućeno jednostavno variranje vršnog ubrzanja zapisa potresa $a_{g}$ [S20].

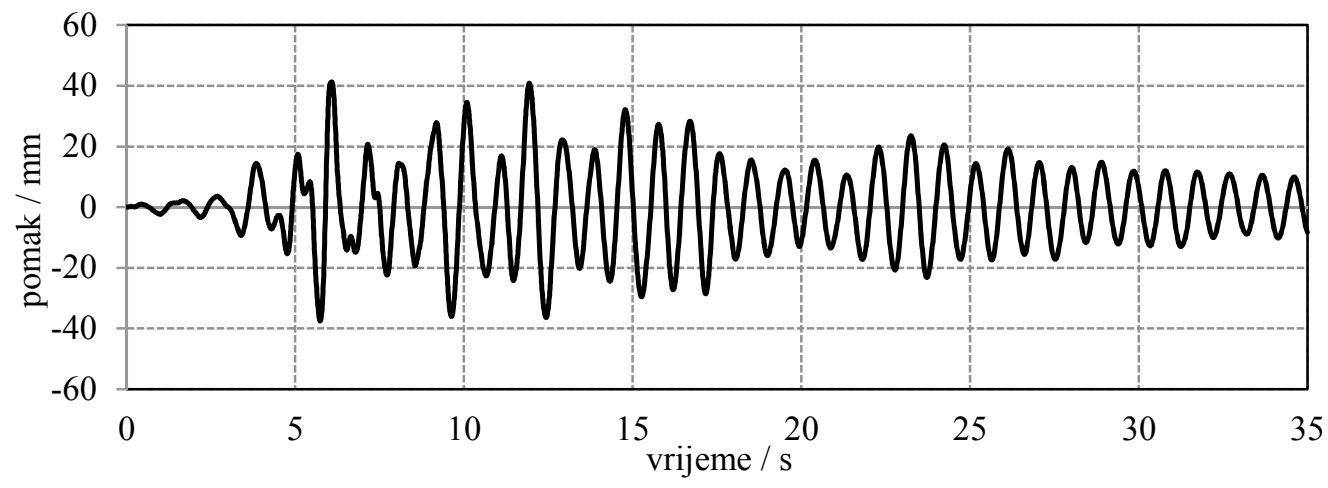

Crtež 6.3 Horizontalni pomak točke vrha luka u vremenu 
$\mathrm{Na}$ crtežu 6.4 prikazan je oblik promatranog luka u vremenu maksimalnog horizontalog pomaka vrha luka, skupa sa čvornim vektorima pomaka i brzina.

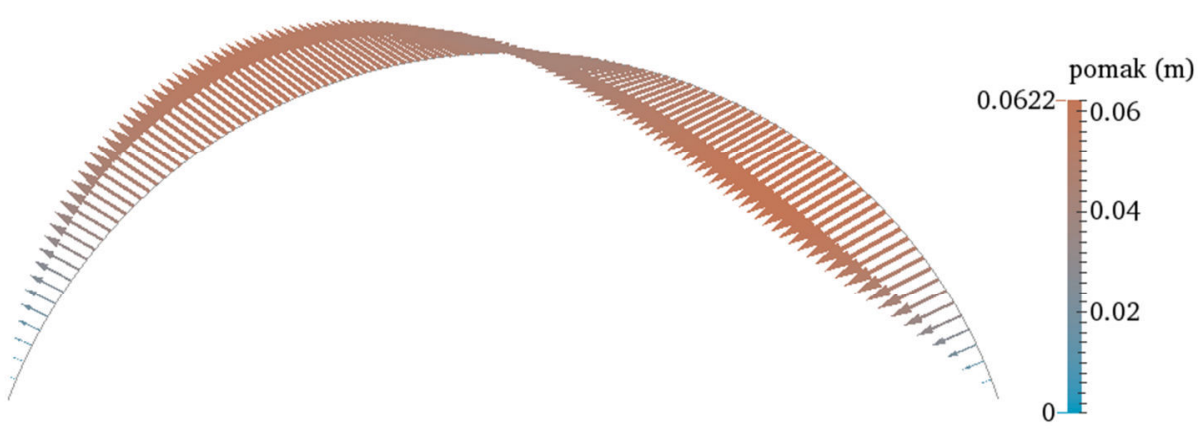

(a)

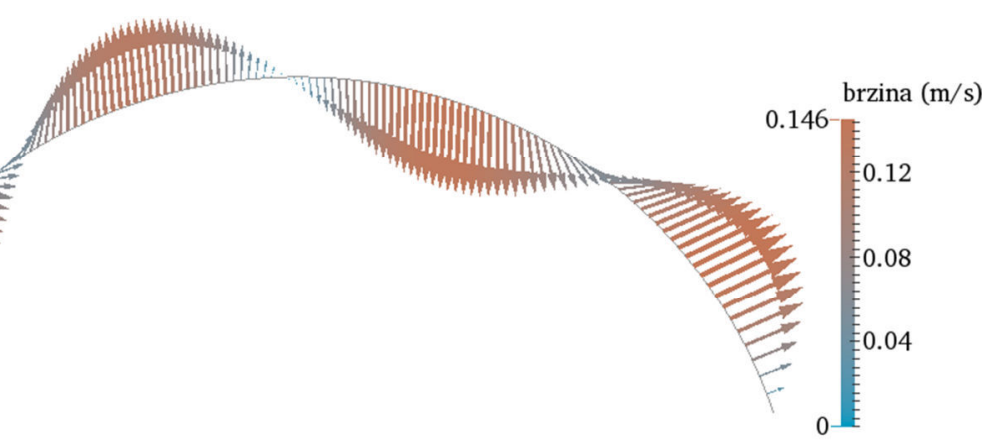

(b)

Crtež 6.4 Vektori pomaka i brzina u trenutku maksimalnog horizontalnog pomaka vrha luka $(t=6.072 \mathrm{~s})$ (a) pomak, (b) brzina

\subsection{KVADRATNA PLOČA POD TLAČNIM OPTEREĆENJEM}

Kvadratna ploča, slobodno oslonjena na dva nasuprotna kraja, odabrana je u svrhu analize gubitka stabilnosti i ponašanja nakon gubitka stabilnosti predloženog MKDE modela. Ploča je podložena monotono rastućem tlačnom opterećenju, izazvanom preko brzine $v$, kako je prikazano na crtežu 6.5 .

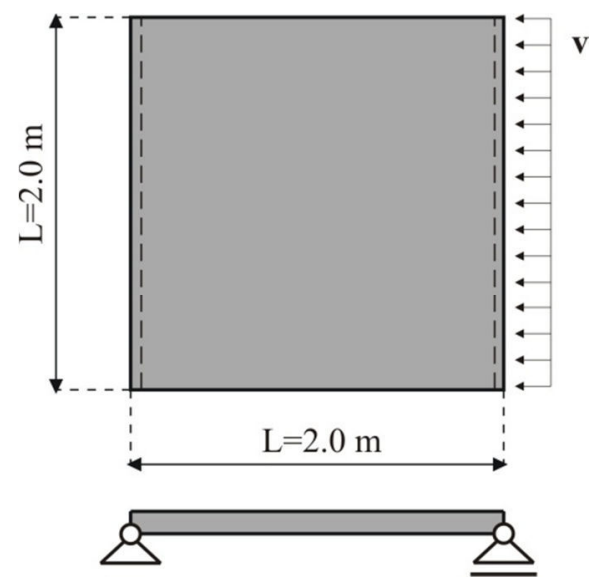

Crtež 6.5 Kvadratna ploča pod tlačnim opterećenjem 
Debljina ploče usvojena je kao $b=5 \mathrm{~mm}$, modul elastičnosti kao $E=210 \mathrm{GPa}$, dok je Poissonov koeficijent jednak nuli. Da bi se u obzir uzeo eventualni dinamički utjecaj u nanošenju tlačnog opterećenja, brzina $v$ varirana je za tri različite vrijednosti

$$
v_{1}=2.142 t \cdot 10^{-9}(\mathrm{~m} / \mathrm{s}) ; \quad v_{2}=5.345 t \cdot 10^{-10}(\mathrm{~m} / \mathrm{s}) ; \quad v_{3}=1.339 t \cdot 10^{-10}(\mathrm{~m} / \mathrm{s}),
$$

gdje $t$ predstavlja vrijeme u sekundama. Diskretizacija ploče izvršena je pomoću 608 konačnih elemenata, kako je prikazano na crtežu 5.19(c).

Kada sila izazvana horizontalnim pomakom uslijed brzine $v$ dosegne kritičnu vrijednost, sustav postaje nestabilan i dolazi do pojave izbočivanja. Da bi se u sustav unio neki oblik imperfekcije, pretpostavljena je zanemarujuće mala vrijednost gravitacije od $g=10^{-10} \mathrm{~m} / \mathrm{s}^{2}$. Rezultati dobiveni predloženim numeričkim modelom, u usporedbi sa analitičkim rješenjem [M6], prikazani su na crtežu 6.6.

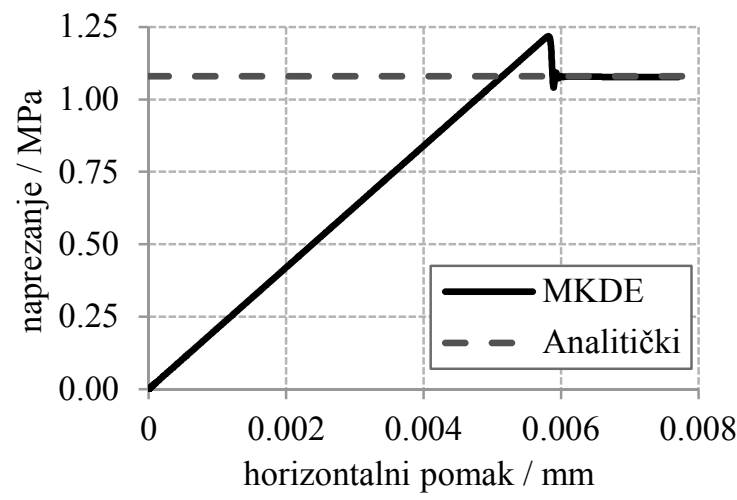

(a)

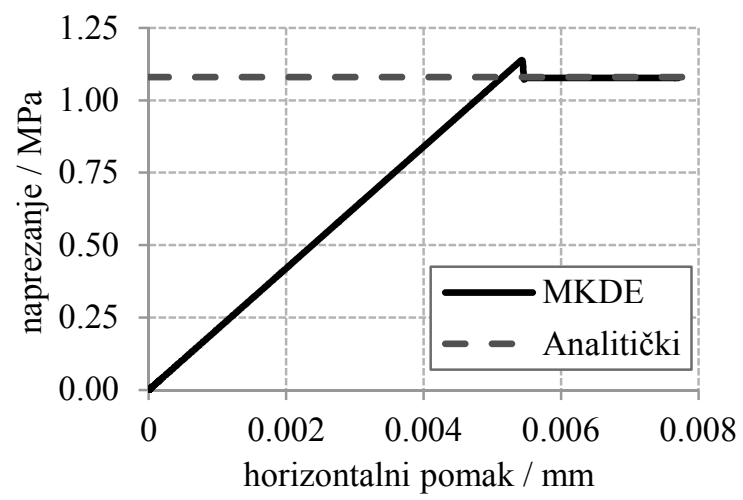

(c)

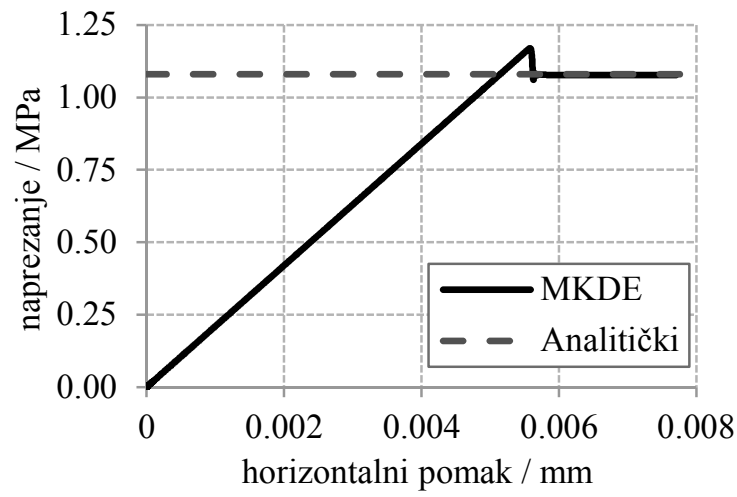

(b)

Crtež 6.6 Odnos sila-pomak na sredini kvadratne ploče opterećene sa (a) $v=v_{l}$, (b) $v=v_{2}$, i (c) $v=v_{3}$.

Na crtežu 6.6. vidljivo je kako kod veće brzine nanošenja opterećenja greda postiže veće naprezanje prije točke gubitka stabilnosti, odnosno kako smanjenjem brzine nanošenja opterećenja 
gubitak stabilnosti se sve više približava dobro poznatoj Eulerovoj sili. Pripadajuća raspodjela pomaka po konstrukciji, prije i poslije točke gubitka stabilnosti, prikazana je na crtežu 6.7.

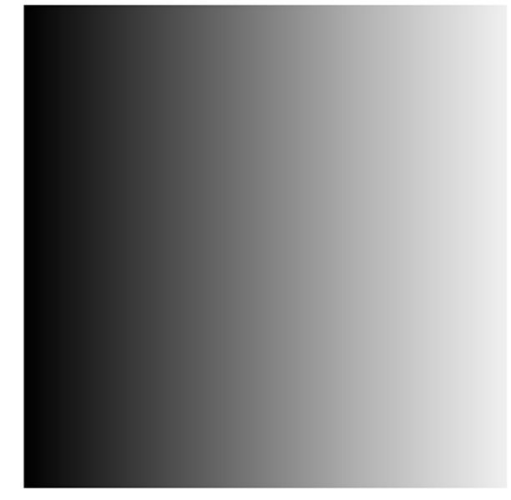

(a)

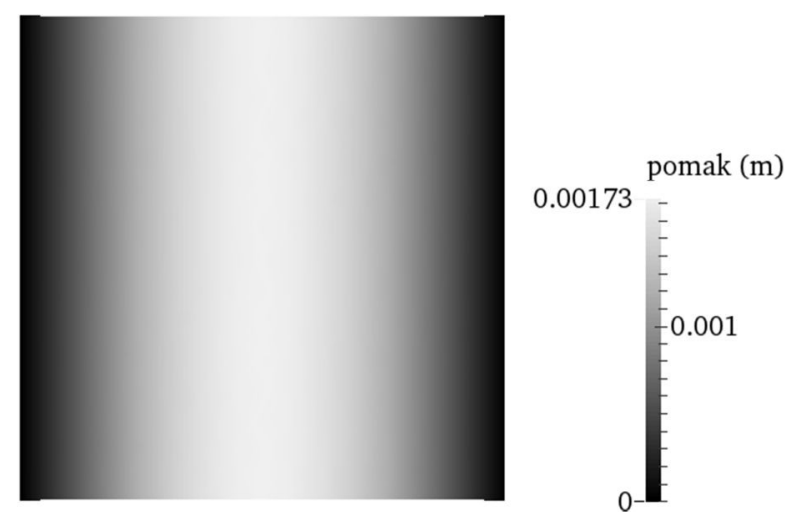

(b)

Crtež 6.7 Raspodjela ukupnih pomaka ploče podložene brzini $v_{3}$, za horizontalni pomak središta od (a) $0.004 \mathrm{~mm}$ i (b) $0.007 \mathrm{~mm}$.

\subsection{SLOBODNO OSLONJENA KVADRATNA PLOČA POD TLAČNIM OPTEREĆENJEM}

Kvadratna ploča, slobodno oslonjena na sva četiri kraja, odabrana je u svrhu dodatne analize gubitka stabilnosti i ponašanja nakon gubitka stabilnosti predloženog MKDE modela. Ploča je podložena monotono rastućem tlačnom opterećenju, izazvanom preko brzine v, kako je prikazano na crtežu 6.8. Debljina ploče usvojena je kao $b=5 \mathrm{~mm}$, modul elastičnosti kao $E=210 \mathrm{GPa}$, dok je Poissonov koeficijent usvojen kao $v=0.3$.

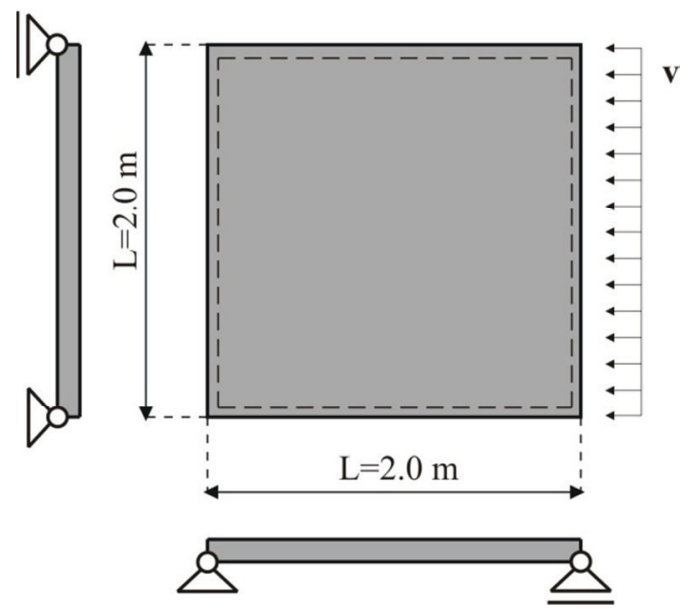

Crtež 6.8 Slobodno oslonjena kvadratna ploča pod tlačnim opterećenjem

Da bi se u obzir uzeo eventualni dinamički utjecaj u nanošenju tlačnog opterećenja, brzina $v$ varirana je za tri različite vrijednosti 


$$
v_{1}=9.417 t \cdot 10^{-9}(\mathrm{~m} / \mathrm{s}) ; \quad v_{2}=2.354 t \cdot 10^{-9}(\mathrm{~m} / \mathrm{s}) ; \quad v_{3}=5.885 t \cdot 10^{-10}(\mathrm{~m} / \mathrm{s}),
$$

gdje $t$ predstavlja vrijeme u sekundama. Diskretizacija ploče izvršena je pomoću 608 konačnih elemenata, kako je prikazano na crtežu 5.19(c).

Kada sila izazvana horizontalnim pomakom uslijed brzine $v$ dosegne kritičnu vrijednost, sustav postaje nestabilan i dolazi do pojave izbočivanja. Da bi se u sustav unio neki oblik imperfekcije, pretpostavljena je zanemarujuće mala vrijednost gravitacije od $g=10^{-10} \mathrm{~m} / \mathrm{s}^{2}$. Rezultati dobiveni predloženim numeričkim modelom, u usporedbi sa analitičkim rješenjem [V1], prikazani su na crtežu 6.9 .

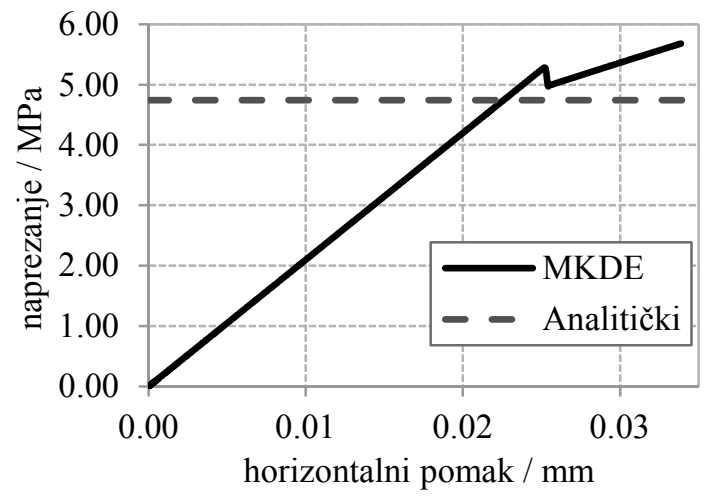

(a)

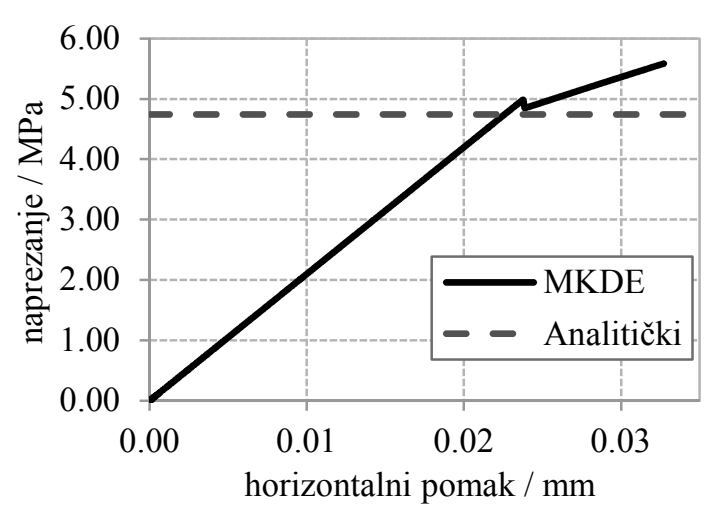

(c)

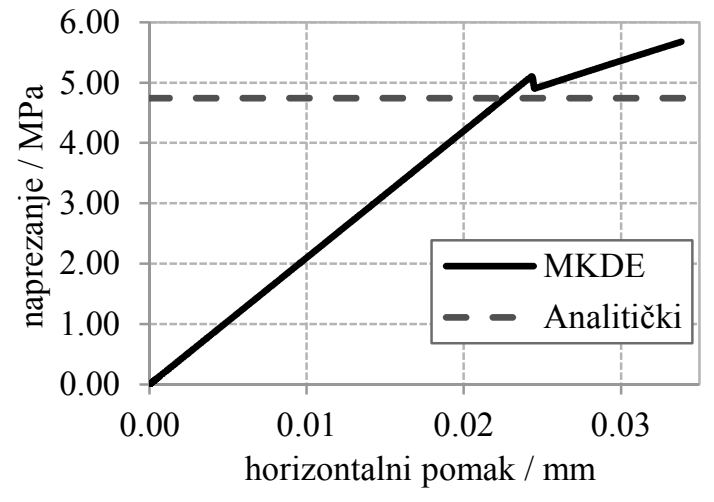

(b)

Crtež 6.9 Odnos sila-pomak na sredini slobodno oslonjene kvadratne ploče opterećene sa (a) $v=v_{l}$, (b) $v=v_{2}, \mathrm{i}(\mathrm{c}) v=v_{3}$.

Na crtežu 6.9. vidljivo je kako kod veće brzine nanošenja opterećenja greda postiže veće naprezanje prije točke gubitka stabilnosti, odnosno kako smanjenjem brzine nanošenja opterećenja gubitak stabilnosti se sve više približava poznatom analitičkom rješenju. Također, vidljivo je kako predloženi model nakon gubitka stabilnosti može podnijeti i veća naprezanja od kritičnih, što je u 
skladu sa poznatim stvarnim ponašanjem prezentiranog problema [R10]. Pripadajuća raspodjela pomaka po konstrukciji, prije i poslije točke gubitka stabilnosti, prikazana je na crtežu 6.10.

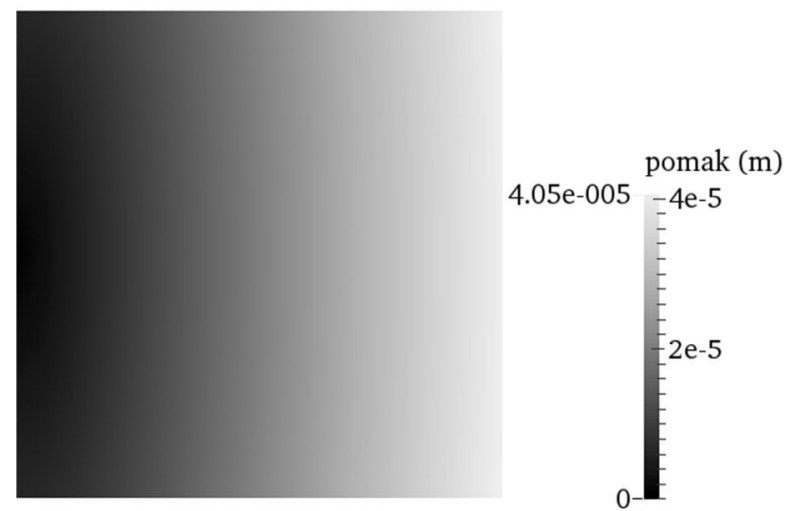

(a)

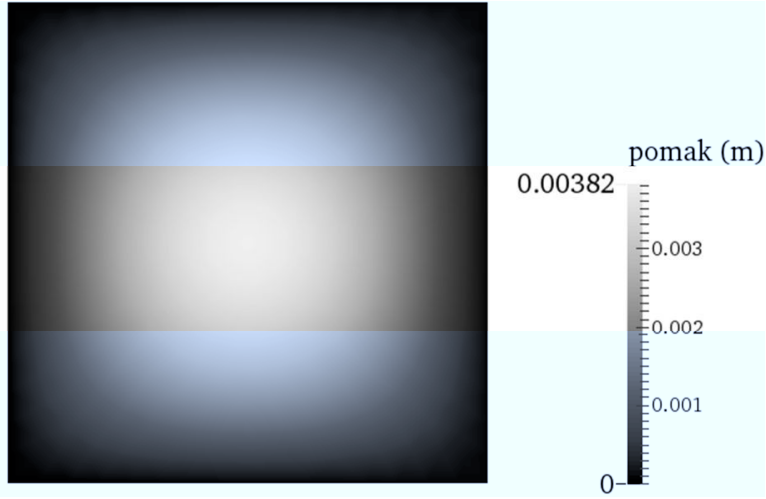

(b)

Crtež 6.10 Raspodjela ukupnih pomaka slobodno oslonjene ploče podložene brzini $v_{3}$, za horizontalni pomak središta od (a) $0.02 \mathrm{~mm}$ i (b) $0.03 \mathrm{~mm}$.

\section{4 ČELIČNI CILINDAR POD TLAČNIM OPTEREĆENJEM}

Čelični cilindar, podložen monotono rastućem tlačnom opterećenju izazvanom preko brzine $v$ kako je prikazano na crtežu 6.11 (a), odabran je u svrhu dodatne analize gubitka stabilnosti i ponašanja nakon gubitka stabilnosti predloženog MKDE modela. Debljina cilindra usvojena je kao $b=5 \mathrm{~mm}$, modul elastičnosti kao $E=210 \mathrm{GPa}$, dok je Poissonov koeficijent $v=0.3$. Brzina opterećenja uzeta je kao

$$
v=2.27 \cdot 10^{-5} t(\mathrm{~m} / \mathrm{s})
$$

gdje $t$ predstavlja vrijeme u sekundama. Diskretizacija cilindra izvršena je pomoću 3922 konačnih elemenata, kako je prikazano na crtežu 6.11 (b).

Kada opterećenje izazvano vertikalnim pomakom uslijed brzine $v$ dosegne kritičnu vrijednost, sustav postaje nestabilan i dolazi do pojave izbočivanja. Iako postoji analitički izraz za kritično naprezanje tlačno opterećenog cilindra [V1], još 1930ih primijetilo se kako je stvarna eksperimentalno dobivena sila kod koje dolazi do izbočivanja značajno manja od one dobivene analitičkim postupkom. Analizom cijelog niza eksperimenata uočeno je kako sa povećanjem odnosa R/b stvarna sila gubitka stabilnosti postaje sve manja u odnosu na analitičku, te kako za konkretni omjer $\mathrm{R} / \mathrm{b}$ u različitim eksperimentima nema konzistentnosti odnosa eksperimentalnih $\mathrm{i}$ analitičkih rezultata [C16]. Iako se kao razlog te pojave navodila pretpostavka analitičkog proračuna u kojoj prije gubitka stabilnosti dolazi do isključivo membranskih naprezanja, kasnije je 
ipak pokazano kako su početne geometrijske imperfekcije dominantan faktor pri određivanju kritične sile [S19]. Odabirom pomno proizvedenih uzoraka kritična opterećenja su se od početnih $15-50 \%$ u odnosu na analitičke vrijednosti popela na 50-90\% [S19]. Daljinom analizom eksperimenata utvrđeno je također da eksperimentalne vrijednosti kritične sile nisu proporcionalne sa (b/R), kako je predviđeno klasičnom linearnom teorijom [C16].

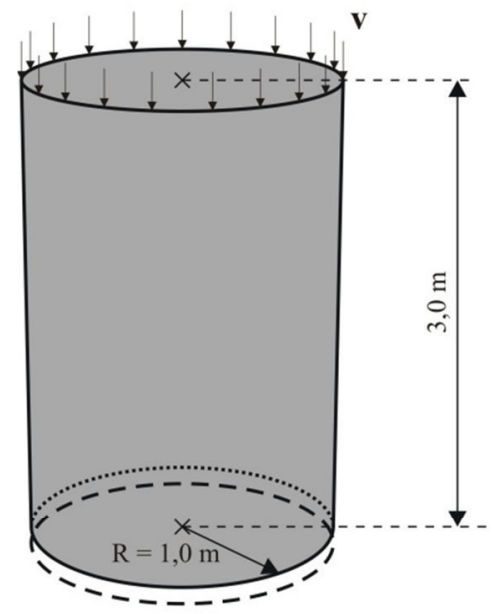

(a)

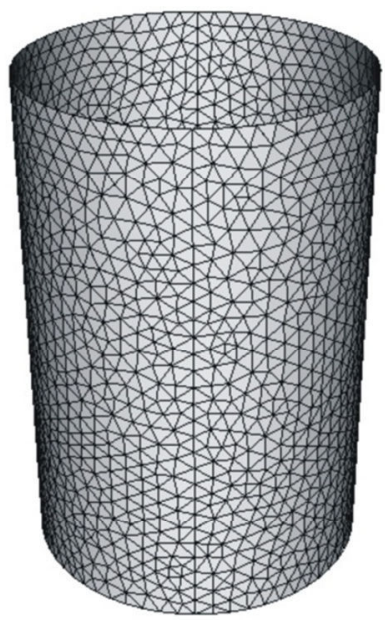

(b)

Crtež 6.11 Slobodno oslonjeni čelični cilindar pod tlačnim opterećenjem (a) geometrija, (b) diskretizacija

Rezultati dobiveni predloženim numeričkim modelom prikazani su na crtežu 6.12. Sa crteža je vidljivo kako do gubitka stabilnosti dolazi prije dosezanja analitičkih kritičnih naprezanja (pri $\left.0.46 \sigma_{\text {krit }}\right)$ [M6], što je u skladu sa navedenim razmatranjima [C16]. Detaljniji zaključci i analize mogući su samo provedbom opsežne analize konkretnog problema, varirajući gustoće mreže konačnih elemenata, brzinu nanošenja opterećenja i debljinu stjenke cilindra, što je ostavljeno izvan opsega ove radnje.

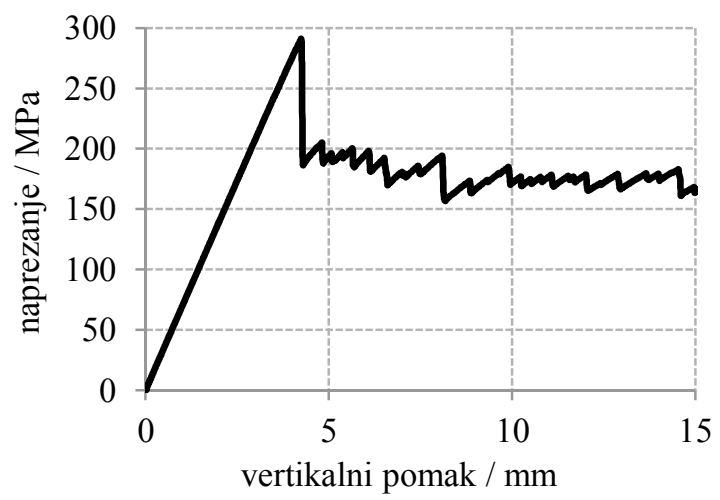

Crtež 6.12 Odnos sila-pomak za slobodno oslonjeni čelični cilindar.

Potrebno je također napomenuti kako kod promatranog primjera nije bilo potrebno unijeti neku vrstu imperfekcije u sustav. Naime, zbog zaokruživanja u iznosima zakrivljenosti kod 
elemenata cilindra bilježe se odstupanja, koja sve dok je cilindar u globalnoj ravnoteži nemaju utjecaj na njegovu globalnu i lokalnu stabilnost. Međutim, u trenutku dosezanja kritičnih naprezanja sustav postaje nestabilan, i upravo tim odstupanjima u kombinaciji sa korištenjem eksplicitne integracije za rješavanje jednadžbi gibanja u vremenu dolazi do pojave lokalne ili globalne nestabilnosti. Raspodjela pomaka po konstrukciji, dobivena predloženim numeričkim modelom prikazana je na crtežu 6.13 .

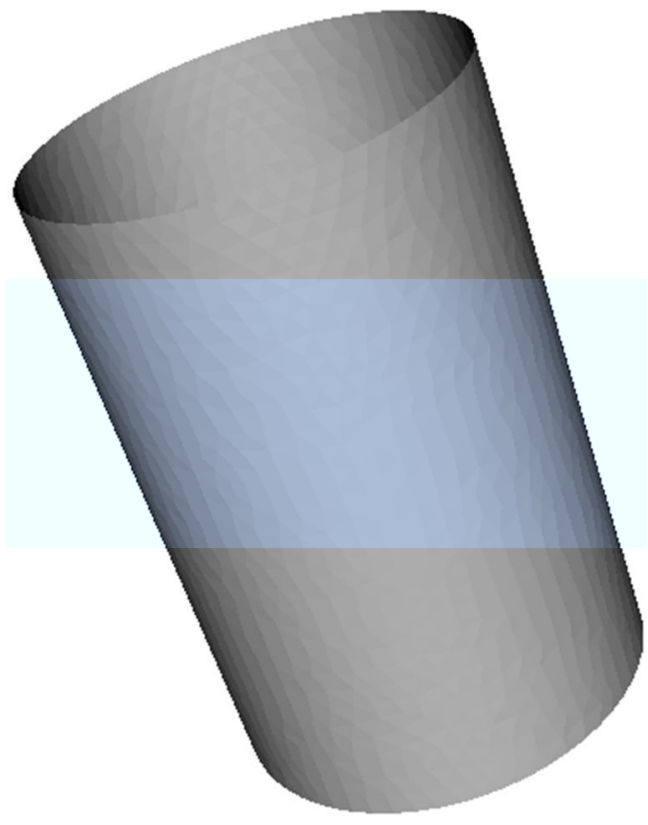

(a)

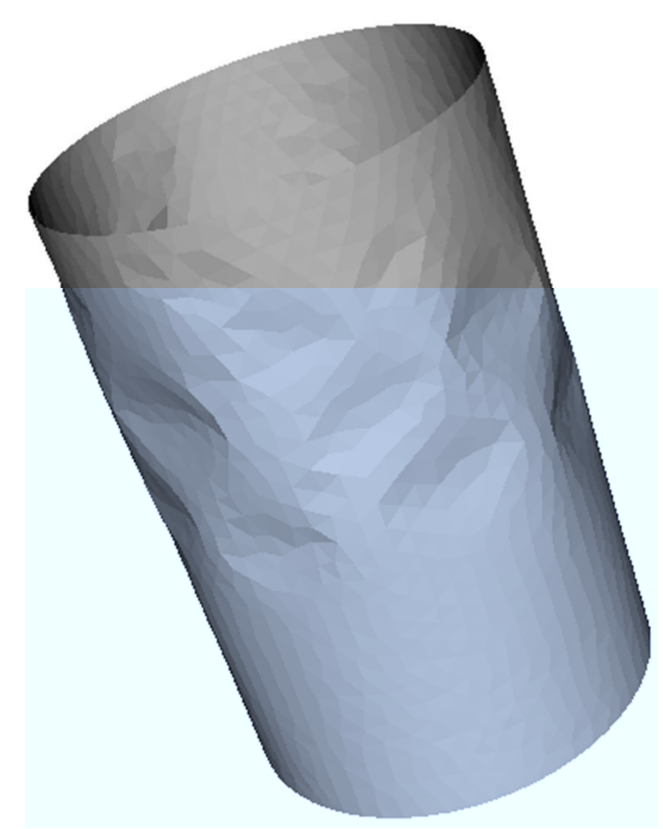

(c)

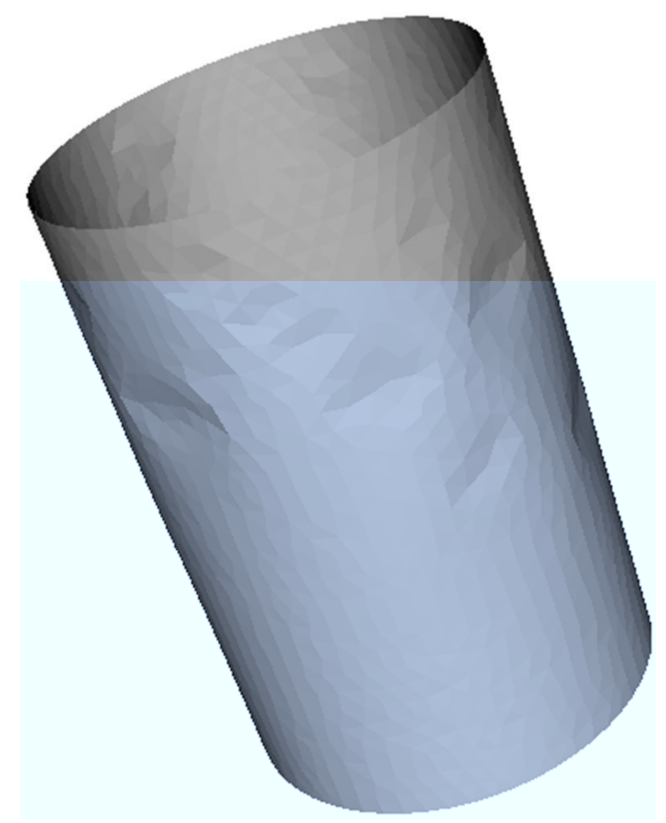

(b)

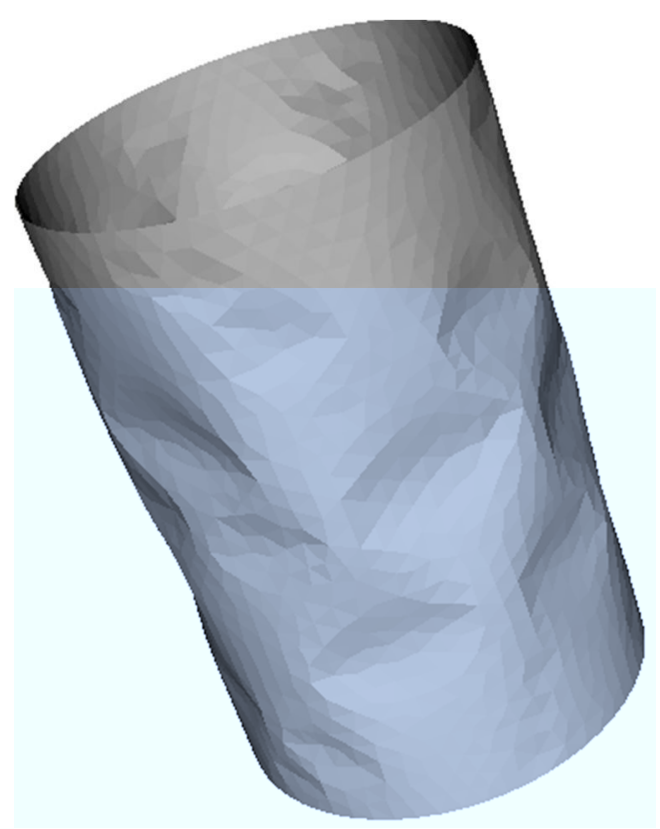

(d)

Crtež 6.13 Čelični cilindar pod tlačnim opterećenjem u vremenima od (a) $10 \mathrm{~s}$, (b) $21 \mathrm{~s}$, (c) $30 \mathrm{~s}$, i (d) $40 \mathrm{~s}$. 


\section{ZAKLJUČCI I PRAVCI DALNJIH ISTRAŽIVANJA}

U prvom dijelu ovog poglavlja iznijet će se osnovni zaključci koji proizlaze iz istraživanja i analiza provedenih u ovom radu, kao i prednosti i nedostaci izloženih modela. Također, navedeni su i mogući pravci daljnjih istraživanja.

\subsection{ZAKLJUČCI}

U ovom radu su u okviru kombinirane metode konačno-diskretnih elemenata predstavljeni novi numerički modeli za analizu tankih lukova i ljusaka izloženih proizvoljnom statičkom i dinamičkom opterećenju. Za razvijene modele nametnuti su zahtjevi preciznosti, jednostavnosti formulacije, računalne učinkovitosti i primjene na proizvoljnu geometriju lukova i ljusaka.

Kombinirana metoda konačno-diskretnih elemenata zasniva se na simulaciji ponašanja velikog broja diskretnih elemenata koji se mogu naći u međusobnoj interakciji. Svaki diskretni element diskretiziran je vlastitom mrežom konačnih elemenata, čime je omogućena njegova deformabilnost. Masa diskretnog elementa nalazi se koncentrirana u čvorovima konačnih elemenata, u kojima se za svaki vremenski korak provodi eksplicitno rješavanje jednadžbe gibanja. Nema potrebe za sastavljanjem matrice masa ni matrice krutosti. 
Integracijom gore navedenih zahtjeva, u sklopu ove disertacije kreiran je originalni numerički model za analizu tankih lukova, čiji znanstveni doprinos uključuje:

- Razvoj novog i originalnog algoritma za statičku, dinamičku i analizu stabilnosti grednih elemenata. Algoritam se bazira na dvočvornim konačnim linijskim elementima oslobođenih rotacije, i uzima u obzir linearno elastično ponašanje materijala uz eksplicitnu integraciju jednadžbe gibanja u vremenu.

- Implementacija novorazvijenog algoritma za statičku, dinamičku i analizu stabilnosti tankih grednih elemenata u Yfdem otvoreni računalni program koji se bazira na MKDE.

- Validacija i primjena novorazvijenog računalnog programa u statičkoj, dinamičkoj i analizi stabilnosti tankih grednih i lučnih konstrukcija. Program u obzir uzima geometrijsku nelinearnost, te konačne pomake i rotacije.

Usporedbom numeričkih rezultata dobivenih računalnim programom Yfdem s rezultatima dostupnima u literaturi, te numeričkim rezultatima dobivenim pomoću računalnih programa za nelinearnu analizu konstrukcija baziranih na metodi konačnih elemenata, pokazalo se da razvijeni numerički model vrlo dobro opisuje ponašanje tankih lučnih i grednih konstrukcija izloženih statičkom i dinamičkom opterećenu. Primjenom open-source platforme Paraview omogućena je vizualizacija rezultata. Također, pokazalo se kako predloženi numerički model može i precizno opisati pojavu gubitka stabilnosti i post-kritičnog ponašanja predmetnih konstrukcija.

Jednostavnost formulacije modela lukova potpomognuta je odabirom ravnih dvočvornih konačnih elemenata. Međutim, opisivanje zakrivljene geometrije luka ravnim elementima, kao i korištenje eksplicitne numeričke integracije jednadžbi gibanja u vremenu dovodi do potrebe za gustom diskretizacijom konstrukcije. Posljedično, to može rezultirati vrlo malim vremenskim korakom, što bitno produljuje i poskupljuje vrijeme proračuna. Smatra se da daljnjim razvojem snage računala, te razvojem paralelnog koda prikladnog za rad na klasteru, ovaj problem može biti znatno smanjen. Međusobna neovisnost jednadžbi gibanja posebno je povoljna za primjenu istovremenog (paralelnog) procesuiranja.

Preciznost i robusnost formulacije za analizu tankih lukova stvorila je temelje za njezino poopćenje na opću analizu tankih ploča i ljusaka. U sklopu ove disertacije kreiran je originalni numerički model za analizu tankih ploča i ljusaka, čiji znanstveni doprinos uključuje:

- Razvoj novog i originalnog algoritma za statičku, dinamičku i analizu stabilnosti tankih ploča i ljusaka. Algoritam se bazira na tročvornim konačnim elementima oslobođenima rotacije, i 
uzima u obzir linearno elastično savojno ponašanje materijala uz eksplicitnu integraciju jednadžbe gibanja u vremenu.

- Implementacija novorazvijenog algoritma za statičku, dinamičku i analizu stabilnosti tankih ploča i ljusaka u Yfdem otvoreni računalni program koji se bazira na MKDE.

- Validacija i primjena novorazvijenog računalnog programa u statičkoj, dinamičkoj i analizi stabilnosti tankih ploča i ljusaka. Program u obzir uzima geometrijsku nelinearnost, te konačne pomake i rotacije.

Izravnim proširivanjem formulacije lukova na analizu ploča i ljuska dolazimo do Modela I, gdje se analiza savojne krutosti provodi promatranjem dvaju susjednih konačnih elemenata. Međutim, budući da dva susjedna elementa nude samo četiri čvora, zakrivljenost ne može biti egzaktno određena. Iz tog razloga potrebno je istodobno promatrati grupu sastavljenu od konačnog elementa i svih njemu susjednih konačnih elemenata, što dovodi do Modela II. Model II je u kasnijim analizama usvojen za proračun savojne krutosti predmetnih konstrukcija.

Usporedbom numeričkih rezultata dobivenih računalnim programom Yfdem s rezultatima dostupnima u literaturi, te numeričkim rezultatima dobivenim pomoću računalnih programa za nelinearnu analizu konstrukcija baziranih na metodi konačnih elemenata, pokazalo se da razvijeni numerički model vrlo dobro opisuje ponašanje tankih ploča i ljusaka izloženih statičkom i dinamičkom opterećenu. Primjenom open-source platforme Paraview omogućena je vizualizacija rezultata. Također, pokazalo se kako predloženi numerički model može precizno opisati pojavu gubitka stabilnosti i post-kritičnog ponašanja predmetnih konstrukcija.

Jednostavnost formulacije potpomognuta je odabirom trokutastih tročvornih konačnih elemenata. Njihov odabir omogućuje i učinkovitu reprezentaciju proizvoljno zakrivljene geometrije. Ekvivalentno modelu lukova, opisivanje zakrivljene geometrije ravnim elementima i korištenje eksplicitne numeričke integracije jednadžbi gibanja u vremenu dovodi do potrebe za gustom diskretizacijom konstrukcije. To nadalje može rezultirati vrlo malim vremenskim korakom, što bitno produljuje i poskupljuje vrijeme proračuna. Smatra se da se daljnjim razvojem snage računala, te razvojem paralelnog koda prikladnog za rad na klasteru, ovaj problem može znatno smanjiti. Međusobna neovisnost jednadžbi gibanja posebno je povoljna za primjenu istovremenog (paralelnog) procesuiranja.

Prema autorovim saznanjima, ovo je za sada jedini model koji omogućuje učinkovitu statičku, dinamičku i analizu stabilnosti tankih ploča i ljuska u sklopu MKDE, koristeći najjednostavnije trokutaste tročvorne konačne elemente. 


\subsection{MOGUĆI PRAVCI DALNJIH ISTRAŽIVANJA}

Mogući pravci daljnjih istraživanja mogu se odvijati u području usavršavanja numeričkog modela, uzimajući u obzir osnovne principe i prednosti MKDE. U nastavku su navedeni neki od njih:

- razvoj modela koji uključuje mogućnost kontaktne interakcije. Ako svakom konačnom elementu pridružimo tri tetraedra, kako je prikazano na crtežu 7.1, već postojeći algoritmi za kontaktnu detekciju i interakciju mogu biti primijenjeni i pri analizi ljusaka. Algoritmi su u Yfdem implementirani prema principima prikazanima u poglavlju 3.1. U okviru takvog proširenja omogućila bi se vremenska analiza ljusaka podloženih udarima, te međusobna interakcija dvaju ljusaka.
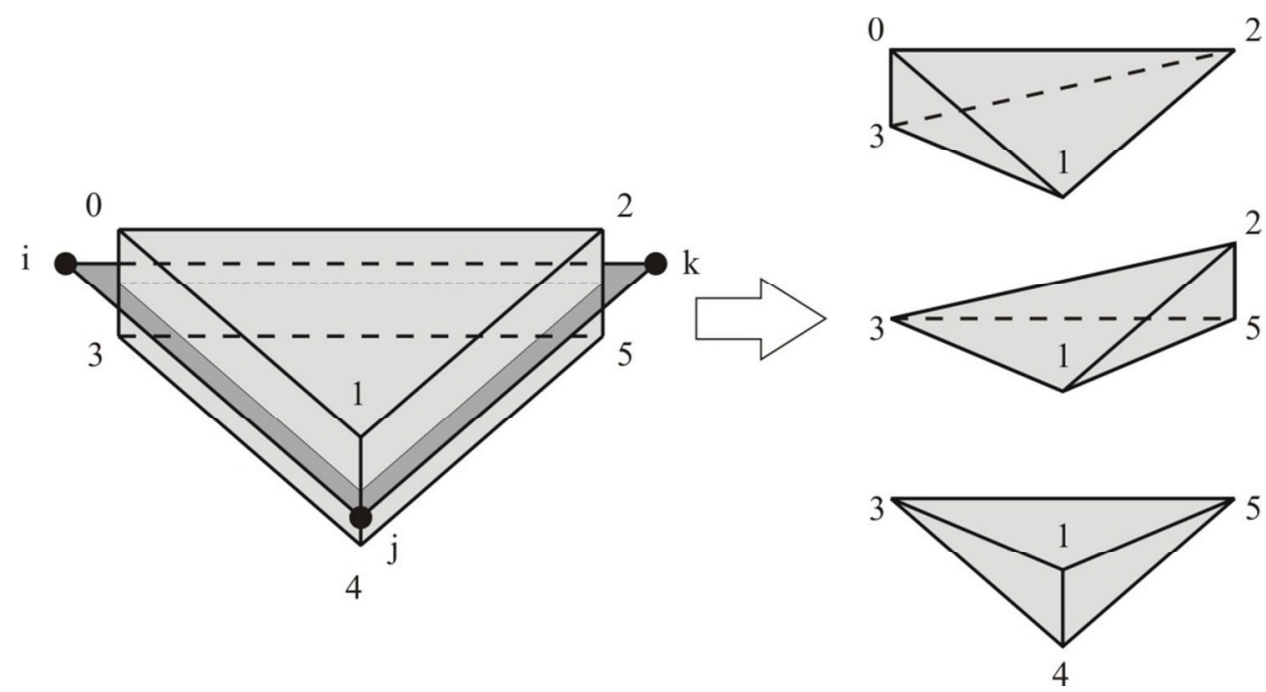

Crtež 7.1 Element ljuske predstavljen preko tetraedara

- poboljšanje numeričkog modela uvođenjem materijalno nelinearnog ponašanja. Promatranjem raspodjele naprezanja po debljini ploče, uz implementaciju nelinearne veze naprezanje-deformacija, može se proračunali moment koji u obzir uzima i materijalnu nelinearnost. To je posebno značajno u analizi tankih ploča, izgrađenih od čelika i aluminija, gdje materijalna nelinearnost posjeduje veliki utjecaj na post-kritično ponašanje.

- razvoj modela interakcije ljusaka sa fluidom. MKDE principi dopuštaju kombiniranje različitih konačnih elemenata, što daje mogućnost opisivanja fluida pomoću već postojećih elemenata tetraedra, oslobađanjem njihove posmične krutosti. Daljnjim kombiniranjem tetraedara sa konačnim elementima za analizu ljuska pružena je mogućnost simuliranja vanjskih udara $\mathrm{i}$ prenošenja udarnog vala na eventualnu tekućinu u zakrivljenoj konstrukciji (npr. silosi). 


\section{LITERATURA}

[A1] Abidin A. R. Z. i Izzuddin B. A. Meshless local buckling analysis of steel beams with irregular web openings [Časopis] Engineering Structures. - 2013. - Svez. 50. - str. 197206.

[A2] Aliabadi M. H. i Wen P. H. Boundary Element Methods in Engineering and Sciences [Knjiga] Imperial College Press, 2011. - Svez. Computational and Experimental Methods in Structures - Vol. 4.

[A3] Allman D. J. A compatible triangular element including vertex rotations for plane elasticity analysis [Časopis] Computers \& Structures. - 1984. - Svez. 19 (1-2). - str. 1-8.

[A4] Allman D. J. Evaluation of the constant strain triangle with drilling rotations [Časopis] International Journal for Numerical Methods in Engineering. - 1988. - Svez. 26 (12). - str. 2645-2655.

[A5] Alvin K., de la Fuente H. M, Haugen B. i Felippa C.A. Membrane triangles with corner drilling freedoms - I. The EFF element [Časopis] Finite Elements in Analysis and Design. 1992. - Svez. 12. - str. 163-187.

[A6] Argyris J. H., Dunne, P. C., Malejannakis, G. A., i Schelkle, E. A simple triangular facet shell element with applications to linear and non-linear equilibrium and elastic stability 
problems [Časopis] Computer Methods in Applied Mechanics and Engineering. - 1977. Svez. 10 (3). - str. 371-403.

[A7] Argyris J., Papadrakakis M. i Mouroutis Z. S. Nonlinear dynamic analysis of shells with the triangular element TRIC [Časopis] Computer methods in applied mechanics and engineering. - 2003. - Svez. 192 (26-27). - str. 3005-3038.

[A8] Arnold D.N. i Brezzi F. The partial selective reduced integration method and applications to shell problems [Časopis] Computers \& Structures. - 1997. - Svez. 64. - str. 879-880.

[A9] Ashwell D.G., Sabir A.B. i Roberts T.M. Further studies in the application of curved finite elements to circular arches [Časopis] International Journal of Mechanical Sciences. 1971. - Svez. 13 (6). - str. 507-517.

[A10] Atluri S. N., Cho J. Y. i Kim H.-G. Analysis of thin beams, using the meshless local Petrov-Galerkin method, with generalized moving least squares interpolations [Časopis] Computational Mechanics. - 1999. - Svez. 24. - str. 334-347.

[A11] Atluri S.N. i Pipkins D.S. Large Deformation Analysis of Plates and Shells [Radovi] Boundary Element Analysis of Plate and Shells / ur. D.E. Beskos. - Springer-Verlag, 1991. - str. 141-166.

[B1] Banerjee P. K. i Butterfield R. Boundary Element Methods in Engineering Science [Knjiga]. - London : McGraw-Hill Inc., 1981.

[B2] Bangash T. i Munjiza A. Experimental validation of a computationally efficient beam element for combined finite-discrete element modelling of structures in distress [Časopis] Computational Mechanics. - 2003. - Svez. 30 (5-6). - str. 366-373.

[B3] Barnes M.R. Form finding and analysis of tension structures by dynamic relaxation $\mathrm{Ph} . \mathrm{D}$. thesis. - London : The City University, 1977.

[B4] Bathe K. J. i Ho L. W. A simple and effective element for analysis of general shell structures [Časopis] Computers \& Structures. - 1981. - Svez. 13 (5-6). - str. 673-681.

[B5] Bathe K.-J. Finite Element Procedures [Knjiga] Prentice-Hall, 1996.

[B6] Batoz J. L., Bathe K. J. i Ho L. W. A study of three-node triangular plate bending elements [Časopis] International Journal for Numerical Methods in Engineering. - 1980. - Svez. 15. - str. 1771-1812. 
[B7] Battini J.-M. A rotation-free corotational plane beam element for non-linear analyses [Časopis] International Journal for Numerical Methods in Engineering. - 2008. - Svez. 75 (6). - str. 672-689.

[B8] Bazeley G. P., Cheung Y. K., Irons, B. M. i Zienkiewicz, O. C. Triangular elements in plate bending, conforming and nonconforming solutions [Konferencija] Proceedings of the First Conference on Matrix Methods in Structural Mechanics . - Wright Patterson Air Force Base: Dayton, Ohio, 1966. - str. 547-576.

[B9] Belinha J. i Dinis L. M. J. S. Nonlinear analysis of plates and laminates using the element free Galerkin method [Časopis] Composite Structures. - 2007. - Svez. 78 (3). - str. 337 350.

[B10] Bergan P. G. i Fellipa C. A. A triangular membrane element with rotational degrees of freedom [Časopis] Computer Methods in Applied Mechanics and Engineering. - 1984. Svez. 50. - str. 24-69.

[B11] Bergan P. G. i Nygard M. K. Finite elements with increased freedom in choosing shape functions [Časopis] International Journal for Numerical Methods in Engineering. - 1985. Svez. 20. - str. 643-664.

[B12] Bezine G. On a method of comparison for plate elements in finite element engineering software programs [Časopis] Mechanics Research Communications. - 2002. - Svez. 22 (1). - str. 35-43.

[B13] Bletzinger K.-U, Bischoff M. i Ekkehard R. A unified approach for shear-locking-free triangular and rectangular shell finite elements [Časopis] Computers \& Structures. 2000. - Svez. 75 (3). - str. 321-334.

[B14] Brasile S. An isostatic assumed stress triangular element for the Reissner-Mindlin platebending problem [Časopis] International Journal for Numerical Methods in Engineering. 2008. - Svez. 74 (6).

[B15] Brebbia C. A., Telles J. C. F. i Wrobel L. Boundary Element Techniques, Theory and Applications in Engineering [Knjiga]. - Berlin : Springer-Verlag, 1984.

[B16] Brunet M. i Sabourin F. A simplified triangular shell element with a necking criterion for 3-D sheet-forming analysis [Časopis] Journal of Materials Processing Technology. 1995. - Svez. 50(1-4). - str. 238-251. 
[B17] Bucalem M.L. i Bathe K.J. Finite Element Analysis of Shell Structures [Arhiv] Archives of Computational Methods in Engineering, State of the art reviews. - Barcelona, 1997. - str. Vol. 4, 1, 3-61.

[C1] Cai Y.C., Tian L.G. i Atluri S.N. A simple locking-free discrete shear triangular plate element [Časopis] Computer Modeling in Engineering \& Sciences. - 2011. - Svez. 77 (4). str. 221-238.

[C2] Carpenter N., Stolarski H. i Belytschko T. A flat triangular shell element with improved membrane interpolation [Časopis] Communications in Applied Numerical Methods. 1985. - Svez. 1. - str. 161-168.

[C3] Cen S. i Shang Y. Developments of Mindlin-Reissner Plate Elements [Časopis] Mathematical Problems in Engineering. - 2015. - Svez. Article ID 456740, in press..

[C4] Chan A. S. L. i Davies G. A. O. A simplified finite element model for the impact of thin shells [Konferencija] Structures under Shock and Impact, Proc. 1st Int. Conf. / ur. Bulson P. S.. - Cambridge, MA, USA, 1989. - str. 365-380.

[C5] Chapelle D. i Bathe K.-J. The Finite Element Analysis of Shells - Fundamentals [Knjiga] Springer, 2011.

[C6] Chen K. K. A triangular plate finite element for large-displacement elastic-plastic analysis of automobile structural components [Časopis] Computers \& Structures. - 1979. - Svez. 10 (1-2). - str. 203-215.

[C7] Chen X. L., Liu G. R. i Lim S. P. An element free Galerkin method for the free vibration analysis of composite laminates of complicated shape [Časopis] Composite Structures. 2003. - Svez. 59 (2). - str. 279-289.

[C8] Choi J.K. i Lim J.K. General curved beam elements based on the assumed strain fields [Časopis] Computers \& Structures. - 1995. - Svez. 55 (3). - str. 379-386.

[C9] Choo Y. S., Choi N. i Lee B. C. A new hybrid-Trefftz triangular and quadrilateral plate elements [Časopis] Applied Mathematical Modelling. - 2010. - Svez. 34 (1). - str. 14-23.

[C10] Cirak F. i Ortiz M. Fully C1-conforming subdivision elements for finite deformation thinshell analysis [Časopis] International Journal for Numerical Methods in Engineering. 2001. - Svez. 51. - str. 813-833. 
[C11] Cirak F., Ortiz M. i Schroder P. Subdivision surfaces: a new paradigm for thin shell finiteelement analysis [Časopis] International Journal for Numerical Methods in Engineering. 2000. - Svez. 47. - str. 2039-2072.

[C12] Cook R. D. A plane hybrid element with rotational d.o.f. and adjustable stiffness [Časopis] International Journal for Numerical Methods in Engineering. - 1987. - Svez. 24 (8). - str. $1499-1508$.

[C13] Cook R. D. On the allman triangle and a related quadrilateral element [Časopis] Computers \& Structures. - 1986. - str. Vol. 22 (6) - str. 1065-1067.

[C14] Cook R. D. Some options for plane triangular elements with rotational degrees of freedom [Časopis] Finite Elements in Analysis and Design. - 1990. - Svez. 6. - str. 245-249.

[C15] Cook R.D., Malkus D., Plesha M. i Witt R. Concepts and Applications of Finite Element Analysis [Knjiga] John Wiley \& Sons, Inc., 2001.

[C16] Calladine C.R. A shell-buckling paradox resolved. U sklopu Durban D., Givoli D, Simmonds J. G. Advances in the Mechanics of Plates and Shells [Knjiga], str. 119-134. Kluwer Academic Publishers, 2000.

[D1] Dawe D. J. Curved finite elements for the analysis of shallow and deep arches [Časopis] Computers \& Structures. - 1974. - Svez. 4 (3). - str. 559-580.

[D2] Dawe D.J. Numerical studies using circular arch finite elements [Časopis] Computers \& Structures. - 1974. - Svez. 4 (4). - str. 729-740.

[D3] Dhatt G., Marcotte L. i Matte Y. A new triangular discrete Kirchhoff plate/shell element [Časopis] International Journal for Numerical Methods in Engineering. - 1986. - Svez. 23 (3). - str. $453-470$.

[D4] Dhondt G. The Finite Element Method fir Three-dimensional Thermomechanical Applications [Knjiga] John Wiley \& Sons, 2004.

[D5] Dinis L.M.J.S., Natal Jorge R.M. i Belinha J. A natural neighbour meshless method with a $3 D$ shell-like approach in the dynamic analysis of thin $3 D$ structures [Časopis] ThinWalled Structures. - Svez. 49 (1). - str. 185-196.

[D6] Dirgantara T. i Aliabadi M.H. A boundary element formulation for geometrically nonlinear analysis of shear deformable shells [Časopis] Computer Methods in Applied Mechanics and Engineering. - 2006. - Svez. 195 (33-36). - str. 4635-4654. 
[D7] Divić V., Uzelac I. i Peroš B. Multiplicative Decomposition Based FDEM Model for Membrane Structures [Časopis] Transactions of FAMENA. - 2014. - Svez. 38.

[D8] Dorfi H.R. i Busby H.R. An effective curved composite beam finite element based on the hybrid-mixed formulation [Časopis] Computers \& Structures. - 1994. - Svez. 53(1). - str. $43-52$.

[D9] Dow J. O. A Unified Approach to the Finite Element Method and Error Analysis Procedures [Knjiga] San Diego: Academic Press, 1999.

[D10] Dung N. i Wells G. Geometrically nonlinear formulation for thin shells without rotation degrees of freedom [Časopis] Computer Methods in Applied Mechanical Engineering. 2008. - Svez. 197. - str. 33-40.

[F1] Fafard M., Dhatt G. i Batoz J. L. A new discrete Kirchhoff plate/shell element with updated procedures [Časopis] Computers \& Structures. - 1989. - Svez. 31 (4). - str. 591-606.

[F2] Fajman P. Membrane triangles with drilling degrees of freedom [Časopis] Acta Polytechnica. - 2004. - Svez. 44.

[F3] Felippa C. A. A study of optimal membrane triangles with drilling freedoms [Časopis] Computer Methods in Applied Mechanics and Engineering. - 2003. - Svez. 192 (16-18). str. 2125-2168.

[F4] Felippa C. A. i Bergan P. G. A triangular bending element based on an energy-orthogonal free formulation [Časopis] Computer Methods in Applied Mechanics and Engineering. 1987. - Svez. 61 (2). - str. 129-160.

[F5] Fellipa C. A. i Alexander S. Membrane triangles with corner drilling freedoms- III. Implementation and performance evaluation [Časopis] Finite Elements in Analysis and Design. - 1992. - Svez. 12. - str. 203-239.

[F6] Fellipa C. A. i Militello C. Membrane triangles with corner drilling freedoms-II. The ANDES element [Časopis] Finite Elements in Analysis and Design. - 1992. - Svez. 12. - str. 189-201.

[F7] Fish J. i Belytschko T. Stabilized rapidly convergent 18-degrees-of-freedom flat shell triangular element [Časopis] International Journal for Numerical Methods in Engineering. - 1992. - Svez. 33. - str. 149-162. 
[F8] Flores F. G. i Onate E. Improvements in the membrane behaviour of the three node rotation-free BST shell triangle using an assumed strain approach [Časopis] Computer Methods in Applied Mechanics and Engineering. - 2005. - Svez. 194. - str. 907-932.

[F9] Flores F. G. i Onate E. Rotation-free element for the non-linear analysis of beams and axisymmetric shells [Časopis] Computer Methods in Applied Mechanics and Engineering. - 2006. - Svez. 195. - str. 5297-5315.

[F10] Friedman Z. i Kosmatka J.B. An accurate two-node finite element for shear deformable curved beams [Časopis] International Journal for Numerical Methods in Engineering. 1998. - Svez. 41(3). - str. 473-498.

[F11] Friedman Z. i Kosmatka J.B. An improved two-node Timoshenko beam beam finite element [Časopis] Computers \& Structures. - 1993. - Svez. 47(3). - str. 473-481.

[G1] Gardsback M. i Tibert G. A comparison of rotation-free triangular shell elements for unstructured meshes [Časopis] Computer Methods in Applied Mechanical Engineering. 2007. - Svez. 196 (49-52). - str. 5001-5015.

[G2] Gardsback M. Deployment Control of Spinning Space Webs and Membranes [Doktorska disertacija] Stockholm : Royal Institute of Technology, Department of Mechanics, 2008.

[G3] Gotovac B., Kozulić V. i Čolak I. Uvod u numeričko modeliranje prostornih konstrukcija [Knjiga] Mostar : Sveučilište u Mostaru, 2001.

[G4] Guo Y.Q., Gati W., Naceur H. i Batoz J. An efficient DKT rotation free shell element for springback simulation in sheet metal forming [Časopis] Computers \& Structures. - 2002. Svez. 82(27-30). - str. 2299-2312.

[H1] Hampshire J. K., Topping B. H. V. i Chan H. C. Three node triangular bending elements with one degree of freedom per node [Časopis] Engineering Computations. - 1992. - Svez. $9(1)$. - str. 49-62.

[H2] Hauptmann R. i Schweizerhof K. A systematic development of solid-shell element formulations for linear and non-linear analysis employing only displacement degrees of freedom [Časopis] International Journal for Numerical Methods in Engineering. - 1998. Svez. 42. - str. 49-69.

[H3] Hein P. Diffuse element method applied to Kirchhoff plates [Izvješće] - Evanston, Ill, USA : Department of Civil Engineering, Northwestern University, 1993. 
[H4] Horrigmoe G. i Bergan P. G. Nonlinear analysis of free-form shells by flat finite elements [Časopis] Computer Methods in Applied Mechanics and Engineering. - 1978. - Svez. 16 (1). - str. 11-35.

[H5] Hsiao K. M. Nonlinear analysis of general shell structures by flat triangular shell element [Časopis] Computers \& Structures. - 1987. - Svez. 25 (5). - str. 665-675.

[H6] Huang M., Zhao Z. i Shen C. An effective planar triangular element with drilling rotation [Časopis] Finite Elements in Analysis and Design. - 2010. - Svez. 46. - str. 1031-1036.

[H7] Hughes T. R. J. i Brezzi F. On drilling degrees of freedom [Časopis] Computer Methods in Applied Mechanics and Engineering. - 1989. - Svez. 72. - str. 105-121.

[H8] Hughes T.J.R. The finite element method, linear static and dynamic finite element analysis [Knjiga] Englewood Cliffs: Prentice-Hall, 1987.

[I1] Ibrahimbegovic A. A novel membrane finite element with an enhanced displacement interpolation [Časopis] Finite Elements in Analysis and Design. - 1990. - Svez. 7. - str. 167-179.

[12] Ibrahimbegovic A. Stress resultant geometrically nonlinear shell theory with drilling rotations-Part I. A consistent formulation [Časopis] 1994. - Svez. 118 (3-4). - str. 265284.

[I3] Iura M. i Atluri S. N. Formulation of a membrane finite element with drilling degrees of freedom [Časopis] Computational Mechanics. - 1992. - Svez. 9. - str. 417-428.

[J1] Jaberzadeh E., Azhari M. i Boroomand B. Inelastic buckling of skew and rhombic thin thickness-tapered plates with and without intermediate supports using the element-free Galerkin method [Časopis] Applied Mathematical Modelling. - 2013. - Svez. 37 (10-11). str. 6838-6854.

[J2] Jeon H. M., Lee, Y., Lee, P. i Bathe K. The MITC3+ shell element in geometric nonlinear analysis [Časopis] Computers \& Structures. - 2015. - Svez. 146. - str. 91-104.

[J3] Jeon H. M., Lee Y., Lee P.S. i Bathe K.J. The MITC3+ shell element in geometric nonlinear analysis [Časopis] Computers \& Structures. - 2015. - Svez. 146. - str. 91-104.

[K1] Kamiya N. i Sawaki Y. An integral equation approach to finite deflection of elastic plates [Časopis] International Journal of Non-Linear Mechanics. - 1982. - Svez. 17 (3). - str. 187 194. 
[K2] Kamiya N. i Sawaki Y. Boundary element method applied to finite deflections of shallow elastic shells [Konferencija] Methodes Numeriques de l'Ingenieur,Comptes Rendus du Troisieme Congres International. - 1983. - str. 63-76.

[K3] Kim D.N. i Bathe K.J. A triangular six-node shell element [Časopis] Computers \& Structures. - 2009. - Svez. 87 (23-24). - str. 1451-1460.

[K4] Kim J.G. i Kim Y.Y. A new higher-order hybrid-mixed curved beam element [Časopis] International Journal for Numerical Methods in Engineering. - 1998. - Svez. 43(5). - str. 925-940.

[K5] Kim J.G. i Park Y.K. Hybrid-mixed curved beam elements with increased degrees of freedom for static and vibration analyses [Časopis] International Journal for Numerical Methods in Engineering. - 2006. - Svez. 68(6). - str. 690-706.

[K6] Kim N. H., Choi K. K., Chen J.S. i Botkin M. E. Meshfree analysis and design sensitivity analysis for shell structures [Časopis] Internationa Journal for Numerical Methods in Engineering. - 2002. - Svez. 53 (9). - str. 2087-2116.

[K7] Knight Jr N. F. The Raasch challenge for shell elements [Časopis] AIAA Journal. - 1997. Svez. 35. - str. 375-381.

[K8] Koschnick F. Geometrische Locking-Effekte bei Finiten Elementen und ein allgemeines Konzept zu ihrer Vermeidung [Doktorska disertacija] Lehrstuhl fur Statik der Technischen Universitat Munchen, 2004.

[K9] Krishnan A. i Suresh Y. J. A simple cubic linear element for static and free vibration analyses of curved beams [Časopis] Computers \& Structures . - 1998. - Svez. 68 (5). - str. 473-489.

[K10] Krishnan A., Dharmaraj S. i Suresh Y.J. Free vibration studies of arches [Časopis] Journal of Sound and Vibration. - 1995. - Svez. 186. - str. 856-63.

[K11] Krysl P. i Belytschko T. Analysis of thin plates by the element-free Galerkin method [Časopis] Computational Mechanics. - 1995. - Svez. 17, (26-35). - str. 26-35.

[K12] Krys1 P. i Belytschko T. Analysis of thin shells by the element-free Galerkin method [Časopis] International Journal of Solids and Structures. - 1993. - Svez. 33, (20-22). - str. 3057-3080. 
[L1] Laurent H. i Rio G. Formulation of a thin shell finite element with continuity CO and convected material frame notion [Časopis] Computational Mechanics. - 2001. - Svez. 27 (3). - str. 218-232.

[L2] Le C. V., Askes H. i Gilbert M. Adaptive element-free Galerkin method applied to the limit analysis of plates [Časopis] Computer Methods in Applied Mechanics and Engineering. 2010. - Svez. 199 (37-40). - str. 2487-2496.

[L3] Lee P.G. i Sin P. C. Locking-free curved beam element based on curvature [Časopis] International Journal for Numerical Methods in Engineering. - 1994. - Svez. 37 (6). - str. 989-1007.

[L4] Lee P.S i Bathe K.J. The quadratic MITC plate and MITC shell elements in plate bending [Časopis] Advances in Engineering Software. - 2010. - Svez. 41 (5). - str. 712-728.

[L5] Lee P.S., Noh H.C i Bathe K.J. Insight into 3-node triangular shell finite elements: the effects of element isotropy and mesh patterns [Časopis] Computers \& Structures. - 2007. Svez. 85 (7-8). - str. 404-418.

[L6] Lee P.-S. i Bathe K. J. Development of MITC isotropic triangular shell finite elements [Časopis] Computers \& Structures. - 2004. - Svez. 82 (11-12). - str. 945-962.

[L7] Lee S.S., Koo J.S. i Choi J.M. Development of a new curved beam element with shear effect [Časopis] Engineering Computations. - 1996. - Svez. 13. - str. 9 - 25.

[L8] Lee Y., Lee P.S. i Bathe K.J. The MITC3+ shell element and its performance [Časopis] Computers \& Structures. - 2014. - Svez. 138 (1). - str. 12-23.

[L9] Lee Y., Yoon K. i Lee P.S. Improving the MITC3 shell finite element by using the Hellinger-Reissner principle [Časopis] Computers \& Structures. - 2012. - Svez. 110-111. str. 93-106.

[L10] Lei X.Y., Huang M.K. i Wang X. Analysis of the explicit fundamental solution of a shallow spherical shell involving shear deformation [Časopis] Applied Mathematical Modelling. - 1995. - Svez. 19 (4). - str. 194-200.

[L11] Leung A.Y.T. i Zhu B. Fourier p-elements for curved beam vibrations [Časopis] ThinWalled Structures. - 2004. - Svez. 42(1). - str. 39-57.

[L12] Levy R. i Gal E. Geometrically nonlinear three-noded flat triangular shell elements [Časopis] Computers \& Structures. - 2001. - Svez. 79. - str. 2349-2355. 
[L13] Li S., Hao W. i Liu W. K. Numerical simulations of large deformation of thin shell structures using meshfree methods [Časopis] Computational Mechanics . - 2000. - Svez. 25, (2-3). - str. 102-116.

[L14] Liew K. M., Peng L. X. i Kitipornchai S. Nonlinear analysis of corrugated plates using a FSDT and a meshfree method [Časopis] Computer Methods in Applied Mechanics and Engineering. - 2007. - Svez. 196 (21-24). - str. 2358-2376.

[L15] Liew K., Peng L. i Kitipornchai S. Buckling analysis of corrugated plates using a meshfree Galerkin method based on the first-order shear deformation theory [Časopis] Computational Mechanics. - 2006. - Svez. 38 (1). - str. 61-75.

[L16] Lin J. i Long S. Geometrically nonlinear analysis of the shallow shell by the displacementbased boundary element formulation [Časopis] Engineering Analysis with Boundary Elements. - 1996. - Svez. 18 (1). - str. 63-70.

[L17] Litewka P. i Rakowski J. An efficient curved beam finite element [Časopis] International Journal for Numerical Methods in Engineering. - 1997. - Svez. 40(14). - str. 2629-2652.

[L18] Litewka P. i Rakowski J. The exact thick arch finite element [Časopis] Computers \& Structures. - 1998. - Svez. 68(4). - str. 369-379.

[L19] Liu G. R. i Chen X. L. A mesh-free method for static and free vibration analyses of thin plates of complicated shape [Časopis] Journal of Sound and Vibration. - 2001. - Svez. 241 (5). - str. 839-855.

[L20] Liu G.R. i Gu Y.T. An Introduction to Meshfree Methods and Their Programming [Knjiga] Springer Netherlands, 2005.

[L21] Liu L., Liu G. R. i Tan V. B. C. Element free method for static and free vibration analysis of spatial thin shell structures [Časopis] Computer Methods in Applied Mechanics and Engineering. - 2002. - Svez. 191 (51-52). - str. 5923-5942.

[L22] Liu Y. Analysis of shell-like structures by the Boundary Element Method based on 3-D elasticity: formulation and verification [Časopis] International Journal for Numerical Methods in Engineering. - 1998. - Svez. 41 (3). - str. 541-558.

[M1] Madenci E. i Barut A. A free-formulation-based flat shell element for non-linear analysis of thin composite structures [Časopis] International Journal for Numerical Methods in Engineering. - 1994. - Svez. 37 (22). - str. 3825-3842. 
[M2] Maunder E. A. W. i Moitinho de Almeida J. P. A triangular hybrid equilibrium plate element of general degree [Časopis] International Journal for Numerical Methods in Engineering. - 2005. - Svez. 63 (3). - str. 315-350.

[M3] Meck H.R. An accurate polynomial displacement function for finite ring elements [Časopis] Computers \& Structures. - 1980. - Svez. 11(4). - str. 265-269.

[M4] Meek J. L. i Tan H. S. A discrete Kirchoff plate bending element with loof nodes [Časopis] Computers \& Structures. - 1985. - Svez. 21 (6). - str. 1197-1212.

[M5] Meek J. L. i Tan H. S. Instability analysis of thin plates and arbitrary shells using a faceted shell element with loof nodes [Časopis] Computer Methods in Applied Mechanics and Engineering. - 1986. - Svez. 57 (2). - str. 143-170.

[M6] Mihanović A. Dinamika konstrukcija [Knjiga] Sveučilište u Splitu, 1995.

[M7] Shin C. M i Lee B. C. Development of a strain-smoothed three-node triangular flat shell element with drilling degrees of freedom [Časopis] Finite Elements in Analysis and Design. - 2014. - Svez. 86. - str. 71-80.

[M8] Moosavi M.R., Delfanian B. i Khelil A. Orthogonal meshless finite volume method in shell analysis [Časopis] Finite Elements in Analysis and Design. - 2012. - Svez. 62. - str. 1-7.

[M9] Morley L. S. D. The constant-moment plate-bending element [Časopis] Journal of Strain Analysis. - 1971. - Svez. 6. - str. 20-24.

[M10] Munjiza A. i Andrews K.R.F. NBS contact detection algorithm for bodies of similar size [Časopis] International Journal for Numerical Methods in Engineering. - 1998. - Svez. 43 (1). - str. 131-149.

[M11] Munjiza A. i Andrews K.R.F. Penalty function method for combined finite-discrete element system comprising large number of separate bodies [Časopis] International Journal for Numerical Methods in Engineering. - 2000. - Svez. 49 (11). - str. 1377-1396.

[M12] Munjiza A. The Combined Finite-Discrete Element Method [Knjiga] John Wiley \& Sons Ltd, 2004.

[M13] Munjiza A., Bangash T. i John N.W.M. The combined finite-discrete element method for structural failure and collapse [Časopis] Engineering Fracture Mechanics. - 2004. - Svez. 71 (4-6). - str. 469-483. 
[M14] Munjiza A., Owen D.R.J. i Crook A.J.L. An $M(M-1 K) m$ proportional damping in explicit integration of dynamic structural systems [Časopis] International Journal for Numerical Methods in Engineering. - 1998. - Svez. 41 (7). - str. 1277-1296.

[M15] Munjiza A., Rougier E. i John N.W.M. MR linear contact detection algorithm [Časopis] International Journal for Numerical Methods in Engineering. - 2006. - Svez. 66 (1). - str. $46-71$.

[M16] Munjiza A., Lei Z., Divić V. i Bernardin P. Fracture and fragmentation of thin shells using the combined finite discrete element method [Časopis] Internationa Journal for Numerical Methods in Engineering. - 2013. - Svez. 95 (6). - str. 478-498.

[M17] Munjiza A., Knight E. i Rougier E. Computational Mechanics of Discontinua [Knjiga] Wiley, 2011.

[M18] Munjiza A., Knight E. i Rougier E. Large Strain Finite Element Method: A Practical Course [Knjiga] Wiley, 2014.

[N1] Nardini D. i Brebbia C.A. A new approach to free vibration analysis using boundary elements [Radovi] Boundary element methods in engineering / ur. Brebbia C.A.. - 1982. str. 312-26.

[N2] Nemetschek Group, Scia Engineer 14 [Software] Minhen, 2014.

[N3] Nguyen-Thoi T. Bui-Xuan T., Phung-Van P., Nguyen-Hoang S. i Nguyen-Xuan H. A cellbased smoothed three-node Mindlin plate element (CS-MIN3) for static and free vibration analyses of plates [Časopis] Computational Mechanics. - 2013. - Svez. 51 (1). - str. 65-81.

[N4] Nguyen-Thoi T., Phung-Van P., Luong-Van H., Nguyen-Van H. i Nguyen-Xuan H. An edge-based smoothed three-node mindlin plate element (ES-MIN3) for static and free vibration analyses of plates [Časopis] KSCE Journal of Civil Engineering/ ur. 10721082. - 2014. - Svez. 18 (4).

[O1] O'Donoghue P.E. i Atluri S.N. Field/boundary element approach to the large deflection of thin flat plates [Časopis] Computers \& Structures. - 1987. - Svez. 27 (3). - str. 427-435.

[O2] Oh H.-S., Davis C. i Jeong J. W. Meshfree particle methods for thin plates [Časopis] Computer Methods in Applied Mechanics and Engineering . - 2012. - Svez. 209-212. - str. 156-171. 
[O3] Onate E. i Cervera M. Derivation of thin plate bending elements with one degree of freedom per node: A simple three node triangle [Časopis] Engineering Computations. 1993. - Svez. 10(6). - str. 543 - 561.

[O4] Onate E., Cendoya P. i Miquel J. Nonlinear explicit dynamic analysis of shells using the BST rotation-free triangle [Časopis] Engineering Computations. - 2002. - Svez. 9(6). - str. $662-706$.

[O5] Onate E., Zarate F. i Flores F. A simple triangular element for thick and thin plate and shell analysis [Časopis] International Journal for Numerical Methods in Engineering. 1994. - Svez. 37 (15). - str. 2569-2582.

[O6] Oñate E. i Zárate F. Extended rotation-free plate and beam elements with shear deformation effects [Časopis] International Journal for Numerical Methods in Engineering. - 2010. - Svez. 83 (2). - str. 196-227.

[O7] Oñate E. i Zárate F. Rotation-free triangular plate and shell elements [Časopis] International Journal for Numerical Methods in Engineering. - 2000. - Svez. 47 (1-3). - str. $557-603$.

[O8] Oral S. i Barut A. A shear-flexible facet shell element for large deflection and instability analysis [Časopis] Computer Methods in Applied Mechanics and Engineering. - 1991. Svez. 93 (3). - str. 415-431.

[P1] Paavilainen J., Tuhkuri J. i Polojärvi A. 2D combined finite-discrete element method to model multi-fracture of beam structures [Časopis] Engineering Computations. - 2009. Svez. 26 (6). - str. 578 - 598.

[P2] Pan K.Q. i Liu J.Y. Geometric nonlinear dynamic analysis of curved beams using curved beam element [Časopis] Acta Mechanica Sinica. - 2011. - Svez. 27(6). - str. 1023-1033.

[P3] Parisch H. An investigation of a finite rotation four node assumed strain shell element [Časopis] International Journal for Numerical Methods in Engineering. - 1991 - Svez. 21. str. 127-150.

[P4] Park K. C. i Stanley G. M. A Curved C0 Shell Element Based on Assumed NaturalCoordinate Strains [Časopis] Journal of Applied Mechanics. - 1986. - Svez. 53 (2). - str. 278-290. 
[P5] Peng L. X., Kitipornchai S. i Liew K. M. Analysis of rectangular stiffened plates under uniform lateral load based on FSDT and element-free Galerkin method [Časopis] International Journal of Mechanical Sciences. - 2005. - Svez. 47 (2). - str. 251-276.

[P6] Peng L. X., Liew K. M. i Kitipornchai S. Analysis of stiffened corrugated plates based on the FSDT via the mesh-free method [Časopis] International Journal of Mechanical Sciences. - 2007. - Svez. 49 (3). - str. 364-378.

[P7] Peng X. i Crisfield M. A. A consistent co-rotational formulation for shells using the constant stress/constant moment triangle [Časopis] International Journal for Numerical Methods in Engineering. - 1992. - Svez. 35 (9). - str. 1829-1847.

[P8] Peric D. i Owen D. R. J. The Morley thin shell finite element for large deformations problems: Simplicity versus sophistication [Konferencija] Proceedings of the International Conference on Nuclear Engineering Computations. - Swansea : Pineridge Press, 1991. str. 121-142.

[P9] Phaal R. i Calladine C. R. A simple class of finite elements for plate and shell problems. I: Elements for beams and thin flat plates. [Časopis] International Journal for Numerical Methods in Engineering. - 1992. - Svez. 35. - str. 955-977.

[P10] Phaal R. i Calladine C.R. A simple class of finite elements for plate and shell problems. II: An element for thin shells, with only translational degrees of freedom [Časopis] International Journal for Numerical Methods in Engineering. - 1992. - Svez. 35(5). - str. 979-996.

[P11] Piltner R. i Taylor R.L. Triangular finite elements with rotational degrees of freedom and enhanced strain modes [Časopis] Computers \& Structures. - 2000. - Svez. 75 (4). - str. 361-368.

[P12] Poulsen P. N. i Damkilde L. A flat triangular shell element with Loof nodes [Časopis] International Journal for Numerical Methods in Engineering. - 1996. - Svez. 39. - str. 3867-3887.

[P13] Prathap G. i Babu C. R. An isoparametric quadratic thick curved beam element [Časopis] International Journal for Numerical Methods in Engineering. - 1986. - Svez. 23 (9). - str. 1583-1600. 
[P14] Prathap G. i Bhashyam G. R. Reduced integration and the shear-flexible beam element [Časopis] International Journal for Numerical Methods in Engineering. - 1982. - Svez. 18 (2). - str. 195-210.

[Q1] Qin Q. i Huang Y. BEM of post-buckling analysis of thin plates [Časopis] Applied Mathematical Modelling. - 1990. - Svez. 14 (10). - str. 544-548.

[R1] Raju I. S., Phillips D. R. i Krishnamurthy T. A radial basis function approach in the meshless local Petrov-Galerkin method for Euler-Bernoulli beam problems [Časopis] Computational Mechanics. - 2004. - Svez. 34 (6). - str. 464-474.

[R2] Raveendranath P., Singh G. i Pradhan B. A two-noded locking-free shear flexible curved beam element [Časopis] International Journal for Numerical Methods in Engineering. 1999. - Svez. 44(2). - str. 265-280.

[R3] Raveendranath P., Singh G. i Venkateswara R. G. A three-noded shear-flexible curved beam element based on coupled displacement field interpolations [Časopis] International Journal for Numerical Methods in Engineering. - 2001. - Svez. 51(1). - str. 85-101.

[R4] Raveendranath P., Singh G. i Pradhan B. Free vibration of arches using a curved beam element based on a coupled polynomial displacement field [Časopis] Computers \& Structures . - 2000. - Svez. 74 (4). - str. 583-590.

[R5] Reddy B.D. i Volpi M.B. Mixed finite element methods for the circular arch problem [Časopis] Computer Methods in Applied Mechanics and Engineering. - 1992. - Svez. 97(1). - str. 125-145.

[R6] Rezaiee-Pajand M. i Karkon M. Two efficient hybrid-trefftz elements for plate bending analysis [Časopis] Latin American Journal of Solids and Structures. - 2012. - Svez. 9 (1). str. 43-67.

[R7] Roelandt J. M. i Batoz J. L. Shell finite element for deep drawing problems: computational aspects and results [Radovi] IUTAM symposium on finite inelastic deformations. - 1992. str. 423-430.

[R8] Rousseau J., Frangin E., Marin P. i Daudeville L. A discrete element/shell finite element coupling for simulating impacts on reinforced concrete structures [Časopis] European Journal of Computational Mechanics. - 2010. - Svez. 19 (1-3). 
[R9] Rousseau J., Marin P., Daudeville L. i Potapovc S. Multidomain finite and discrete elements method for impact analysis of a concrete structure [Časopis] Engineering Structures. - 2009. - Svez. 31 (11). - str. 2735-2743.

[R10] Rhodes J. Some observations on the post-buckling behaviour of thin plates and thin-walled members [Časopis] Thin-Walled Structures. - 2003. - Svez. 41 (2-3). - str. 207-226.

[S1] Sabourin F. i Brunet M. Analysis of plates and shells with a simplified three node triangular element [Časopis] Thin-Walled Structures. - 1995. - Svez. 21. - str. 209-223.

[S2] Saffari H. i Tabatabaei R. A finite circular arch element based on trigonometric shape functions [Časopis] Mathematical Problems in Engineering. - 2007. - str. 78507.

[S3] Saffari H., Tabatabaei R. i Mansouri S.H. Vibration analysis of circular arch element using curvature [Časopis] Shock and Vibration. - 2008. - Svez. 15(5). - str. 481-492.

[S4] Saleeb A.F. i Chang T.Y. On the hybrid-mixed formulation C0 curved beam elements [Časopis] Computer Methods in Applied Mechanics and Engineering. - 1987. - Svez. 60(1). - str. 95-121.

[S5] Saritas A. Modeling of inelastic behavior of curved members with a mixed formulation beam element [Časopis] Finite Elements in Analysis and Design. - 2009. - Svez. 45(5). str. 357-368.

[S6] Serpik I. N. Development of a new finite element for plate and shell analysis by application of generalized approach to patch test [Časopis] Finite Elements in Analysis and Design. 2010. - Svez. 46 (11). - str. 1017-1030.

[S7] Shin C.M. i Lee B.C. Development of a strain-smoothed three-node triangular flat shell element with drilling degrees of freedom [Časopis] Finite Elements in Analysis and Design. - 2014. - Svez. 86 (1). - str. 71-80.

[S8] Simo J. C. i Fox D. D. On a stress resultant geometrically exact shell model. Part I: Formulation and optimal parametrization [Časopis] Computer Methods in Applied Mechanics and Engineering. - 1989. - Svez. 72 (3). - str. 267-304.

[S9] Simo J. C. i Rifai M. S. A class of mixed assumed strain methods and the method of incompatible modes [Časopis] International Journal for Numerical Methods in Engineering. - 1990. - Svez. 29. - str. $1595-1638$.

[S10] Simulia Dassault Systémes, ABAQUS Version 6.13 Documentation [Software] - 2013. 
[S11] Sorić J. Metoda konačnih elemenata [Knjiga] Zagreb : Golden marketing-Tehnička knjiga, 2004.

[S12] Specht B. Modified shape functions for the three-node plate bending element passing the patch test [Časopis] International Journal for Numerical Methods in Engineering. - 1988. Svez. 26 (3). - str. 705-715.

[S13] Stolarski H i Belytschko T. Shear and membrane locking in curved C0 elements [Časopis] Computer Methods in Applied Mechanics and Engineering. - 1983. - Svez. 41 (3). - str. 279-296.

[S14] Sun Y.B., He X.Q. i Qin Q.H. A new procedure for the nonlinear analysis of Reissner plate by boundary element method [Časopis] Computers \& Structures. - 1994. - Svez. 53 (3). - str. 649-652.

[S15] Supriyono i Aliabadi M.H. Boundary element method for shear deformable plates with combined geometric and material nonlinearities [Časopis] Engineering Analysis with Boundary Elements. - 2006. - Svez. 30 (1). - str. 31-42.

[S16] Surana K. S. Geometrically nonlinear formulation for the curved shell elements [Časopis] International Journal for Numerical Methods in Engineering. - 1983. - Svez. 19. - str. 581615.

[S17] Sze K. Y. i Zhu D. A quadratic assumed natural strain triangular element for plate bending analysis [Časopis] Communications in Numerical Methods in Engineering. 1998. - Svez. 14 (11). - str. 1013-1025.

[S18] Sze K. Y., Zhu D. i Chen D.P. Quadratic triangular C0 plate bending element [Časopis] International Journal for Numerical Methods in Engineering. - 1997. - Svez. 40 (5). - str. 937-951.

[S19] Simitses G. J. Buckling and postbuckling of imperfect cylindrical shells: A review [Časopis] Applied Mechanics Reviews. - 1986. - Svez. 39 (10). - str. 1517-1524.

[S20] Smoljanović H. Seizmička analiza zidanih konstrukcija metodom konačno-diskretnih elemenata [Doktorska disertacija] Fakultet građevinarstva, arhitekture i geodezije, 2013.

[T1] Tanaka M. Large deflection analysis of thin elastic plates [Radovi] Developments in Boundary Element Methods. - Berlin : Springer-Verlag, 1984. 
[T2] Tanaka M., Matsumoto T. i Zheng Z. Application of the boundary-domain element method to the pre/post-buckling problem of von Kármán plates [Časopis] Engineering Analysis with Boundary Elements. - 1999. - Svez. 23 (5-6). - str. 399-404.

[T3] Tanaka M., Matsumoto T. i Zheng Z. Incremental analysis of finite deflection of elastic plates via boundary-domain-element method [Časopis] Engineering Analysis with Boundary Elements. - 1996. - Svez. 17 (2). - str. 123-131.

[T4] Tang Y. Q., Zhou Z. H. i Chan S. L. An accurate curved beam element based on trigonometrical mixed polynomial function [Časopis] International Journal of Structural Stability and Dynamics. - 2013. - Svez. 13 (04).

[T5] Taylor R.L. i Auricchio F. Linked interpolation for Reissner-Mindlin plate elements: Part II-A simple triangle [Časopis] International Journal for Numerical Methods in Engineering. - 1993. - Svez. 36 (18). - str. 3057-3066.

[T6] Tessler A. i Hughes T. J. R. A three-node mindlin plate element with improved transverse shear [Časopis] Computer Methods in Applied Mechanics and Engineering. - 1985. - Svez. 50 (1). - str. $71-101$.

[T7] Tessler A. i Spiridigliozzi L. Curved beam elements with penalty relaxation [Časopis] International Journal for Numerical Methods in Engineering. - 1986. - Svez. 23(12). - str. $2245-2262$.

[T8] Tiago C.M. i Leitao V.M.A. Analysis of free vibration problems with the Element-Free Galerkin method [Radovi] Numerical Methods in Continuum Mechanics. - Žilina, Slovak Republic - 2003.

[T9] Tian R. i Yagawa G. Allman's triangle, rotational DOF and partition of unity [Časopis] International Journal for Numerical Methods in Engineering. - 2007. - Svez. 69 (4). - str. $837-858$.

[T10] Tosaka N. i Miyake S. Non-linear analysis of elastic shallow shells by boundary element method [Radovi] Boundary Elements VII / ur. Brebbia C.A. : Springer-Verlag, 1985. - str. $4-43 / 4-52$.

[U1] Useche J. i Albuquerque E.L. Transient dynamic analysis of shear deformable shallow shells using the boundary element method [Časopis] Engineering Structures. - 2015. Svez. 87. - str. 1-7. 
[U2] Useche J. Vibration analysis of shear deformable shallow shells using the Boundary Element Method [Časopis] Engineering Structures. - 2014. - Svez. 62-63. - str. 65-74.

[V1] Ventsel E. i Krauthammer T. Thin Plates and Shells Theory, Analysis and Applications [Knjiga] - New York : Marcel Dekker, Inc., 2001.

[W1] Wang D. i Chen J.-S. A locking-free meshfree curved beam formulation with the stabilized conforming nodal integration [Časopis] Computational Mechanics. - 2006. - Svez. 39 (1). str. 83-90.

[W2] Wang D. i Lin Z. Free vibration analysis of thin plates using Hermite reproducing kernel Galerkin meshfree method with sub-domain stabilized conforming integration [Časopis] Computational Mechanics. - 2010. - Svez. 46 (5). - str. 703-719.

[W3] Wang D. i Peng H. A Hermite reproducing kernel Galerkin meshfree approach for buckling analysis of thin plates [Časopis] Computational Mechanics. - 2013. - Svez. 51 (6). - str. 1013-1029.

[W4] Wang W., Ji X. i Tanaka M. A dual reciprocity boundary element approach for the problems of large deflection of thin elastic plates [Časopis] Computational Mechanics. 2000. - Svez. 26 (1). - str. 58-65.

[W5] Wen P.H., Aliabadi M.H. i Young A. A boundary element method for dynamic plate bending problems [Časopis] International Journal of Solids and Structures. - 2000. - Svez. 37 (37). - str. 5177-5188.

[W6] Wen P.H., Aliabadi M.H. i Young A. Application of dual reciprocity method to plates and shells [Časopis] Engineering Analysis with Boundary Elements. - 2000. - Svez. 24 (7-8). str. 583-590.

[W7] Wen P.H., Aliabadi M.H. i Young A. Large deflection analysis of Reissner's plate by boundary element method [Časopis] Computers \& Structures. - 2005. - Svez. 83 (10-11). str. 870-879.

[W8] Wen P.H., Aliabadi M.H. i Young A. Post buckling analysis of Reissner plates by the boundary element method [Časopis] The Journal of Strain Analysis for Engineering Design. - 2006. - Svez. 41 (3). - str. 239-252.

[W9] Wu J.S. i Chiang L.K. Free vibration analysis of arches using curved beam elements [Časopis] International Journal for Numerical Methods in Engineering. - 2003. - Svez. 58(13). - str. 1907-1936. 
[W10] Wu J.S. i Chiang L.K. Free vibration of a circularly curved Timoshenko beam normal to its initial plane using finite curved beam elements [Časopis] Computers \& Structures. 2004. - Svez. 82(29-30). - str. 2525-2540.

[X1] Xia J.M., Wei D.M. i Jin R.H. Meshless analysis of geometrically nonlinear beams [Radovi] International Symposium on Nonlinear Dynamics. IOP Publishing, 2007.

[Y1] Ye J. Axisymmetric nonlinear analysis of shallow spherical shells by a combined boundary element and finite difference method [Časopis] Engineering Analysis with Boundary Elements. - 1992. - Svez. 9 (4). - str. 283-287.

[Y2] Ye T.Q i Liu Y. Finite deflection analysis of elastic plate by the boundary element method [Časopis] Applied Mathematical Modelling. - 1985. - Svez. 9 (3). - str. 183-188.

[Z1] Zhang C. i Di S. New accurate two-noded shear-flexible curved beam elements [Časopis] Computational Mechanics. - 2003. - Svez. 30(2). - str. 81-87.

[Z2] Zhang J. D. i Atluri S. N. Post-buckling analysis of shallow shells by the field-boundaryelement method [Časopis] International Journal for Numerical Methods in Engineering. 1988. - Svez. 26 (3). - str. 571-587.

[Z3] Zhou Y.X. i Sze K.Y. A geometric nonlinear rotation-free triangle and its application to drape simulation [Časopis] International Journal for Numerical Methods in Engineering. 2012. - Svez. 89 (4). - str. 509-536.

[Z4] Zhou Y.X. i Sze K.Y. A rotation-free beam element for beam and cable analyses [Časopis] Finite Elements in Analysis and Design. - 2013. - Svez. 64. - str. 79-89.

[Z5] Zhuang X.Y., Huang R., Zhu H., Askes H. i Mathisen, K. A new and simple locking-free triangular thick plate element using independent shear degrees of freedom [Časopis] Finite Elements in Analysis and Design. - 2013. - Svez. 75. - str. 1-7.

[Z6] Zienkiewicz O. C., Taylor R. L. i Too J. M. Reduced integration techniques in general analysis of plates and shells [Časopis] International Journal for Numerical Methods in Engineering. - 1971. - Svez. 3 (2). - str. 275-290.

[Z7] Zienkiewicz O.C. i Taylor R.L. The Finite Element Method, Fifth edition [Knjiga] Oxford: McGraw-Hill, 2000.

[Internetske stranice:]

https://en.wikipedia.org; http://www.lusas.com; http://www.cmdingenieros.com 


\section{Životopis}

Ivana Uzelac, dipl. ing. građ. rođena je 19. rujna 1983. godine u Splitu. Osnovnu školu završila je u Kaštel Starom, nakon čega završava Prirodoslovno-matematičku gimnaziju u Splitu. Akademske godine 2001./2002. upisala je Fakultet građevinarstva, arhitekture i geodezije u Splitu, na kojem je diplomirala 29.ožujka 2007. godine.

Od 02. svibnja, 2007. do 31. siječnja, 2010. zaposlena je u građevinskoj tvrtki “'Konstruktor-inženjering d.d.'” u Splitu kao inženjer za razradu izvedbenih projekata i natječajne dokumentacije.

Od 01. veljače, 2010. zaposlena je na Fakultetu građevinarstva, arhitekture i geodezije u Splitu kao znanstveni novak, pri Katedri za metalne i drvene konstrukcije, te sudjeluje u nastavi održavajući vježbe iz predmeta Metalne konstrukcije i Drvene konstrukcije na stručnom studiju građevinarstva, Osnove metalnih konstrukcija i Osnove drvenih konstrukcija na preddiplomskom sveučilišnom studiju građevinarstva, Nosive konstrukcije II na preddiplomskom sveučilišnom studiju arhitekture, te Pouzdanost konstrukcija i Metalni mostovi na diplomskom sveučilišnom studiju građevinarstva. U svibnju 2007. godine upisala je poslijediplomski znanstveni studij iz znanstvenog područja Tehničkih znanosti, znanstveno polje Građevinarstvo, znanstvena grana Nosive konstrukcije.

U proteklom periodu objavila je u koautorstvu 5 znanstvenih članaka u časopisima i zbornicima znanstvenih skupova u zemlji i inozemstvu. 